\title{
Parliamentary immunity : a comprehensive study of the systems of parliamentary immunity of the United Kingdom, France, and the Netherlands in a European context
}

Citation for published version (APA):

Hardt, S. (2013). Parliamentary immunity : a comprehensive study of the systems of parliamentary immunity of the United Kingdom, France, and the Netherlands in a European context. [Doctoral Thesis, Maastricht University]. Maastricht University. https://doi.org/10.26481/dis.20130926sh

Document status and date:

Published: 01/01/2013

DOI:

10.26481/dis.20130926sh

Document Version:

Publisher's PDF, also known as Version of record

Please check the document version of this publication:

- A submitted manuscript is the version of the article upon submission and before peer-review. There can be important differences between the submitted version and the official published version of record. People interested in the research are advised to contact the author for the final version of the publication, or visit the DOI to the publisher's website.

- The final author version and the galley proof are versions of the publication after peer review.

- The final published version features the final layout of the paper including the volume, issue and page numbers.

Link to publication

\footnotetext{
General rights rights.

- You may freely distribute the URL identifying the publication in the public portal. please follow below link for the End User Agreement:

www.umlib.nl/taverne-license

Take down policy

If you believe that this document breaches copyright please contact us at:

repository@maastrichtuniversity.nl

providing details and we will investigate your claim.
}

Copyright and moral rights for the publications made accessible in the public portal are retained by the authors and/or other copyright owners and it is a condition of accessing publications that users recognise and abide by the legal requirements associated with these

- Users may download and print one copy of any publication from the public portal for the purpose of private study or research.

- You may not further distribute the material or use it for any profit-making activity or commercial gain

If the publication is distributed under the terms of Article 25fa of the Dutch Copyright Act, indicated by the "Taverne" license above, 


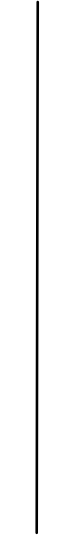

\section{Parliamentary Immunity}

A Comprehensive Study of the Systems of Parliamentary Immunity of the United Kingdom, France, and the Netherlands in a European Context 



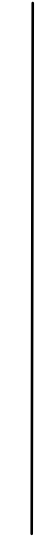

\section{Parliamentary Immunity}

\section{A Comprehensive Study of the Systems of Parliamentary Immunity of the United Kingdom, France, and the Netherlands in a European Context}

\author{
DISSERTATION
}

to obtain the degree of Doctor at the Maastricht University, on the authority of the Rector Magnificus, Prof. dr. L.L.G. Soete in accordance with the decision of the Board of Deans, to be defended in public

on Thursday 26 September 2013, at 16.00 hours

by

Sascha Hardt 

Für Danielle 



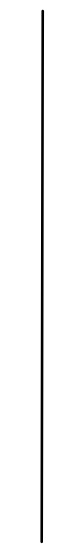

\section{ACKNOWLEDGEMENTS}

As I have been told, the idea that I could write a doctoral dissertation first occurred to Philipp Kiiver when he was supervising my bachelor thesis in 2007. At that time, I may well have dreamed of a PhD position, but I was far from having any actual plans, let alone actively pursuing them. Yet, not a year later, Luc Verhey and Philipp Kiiver asked me whether I was interested to join the newly founded Montesquieu Institute Maastricht as a PhD researcher. I was more than interested but nevertheless declined the offer, instead choosing to embark on the six-month trip around the world I had planned for years. I was certain that this would be the end of my academic aspirations, but thanks to the persistence of my two supervisors it turned out differently: sitting in a little boat between two islands in the Indian Ocean, I received a phone call from Maastricht and was offered to start my $\mathrm{PhD}$ half a year later than initially planned.

I am most thankful to Luc Verhey and Philipp Kiiver for this second chance, for their far-sightedness, their great patience before and during the time of my appointment as a PhD candidate, and their sustained faith in my potential. I am also particularly grateful for their style of supervision: both were never indifferent, always interested and constantly ready to offer constructive criticism. At the same time, their supervision was never 'intrusive'. From the initial research proposal to the very last pages I was given - and greatly enjoyed! - the freedom to conduct my research completely independently, approach my subject in the way I pleased and write this book when and where I saw fit - mostly during unorthodox nocturnal working hours. In short, I could not have been luckier with my supervisors.

I also extend my warmest thanks and appreciation to my (former) colleagues at the Montesquieu Institute Maastricht and the capaciteitsgroep publiekrecht. Without the many extended lunch breaks, research meetings and discussions over coffee with Mira Scholten, Christian Syrier, Wytze van der Woude, Danielle Wenders, Rob van de Westelaken, Sandor Loeffen and Joop van den Berg, writing this book would have been a much more difficult and all too solitary exercise. I always particularly enjoyed working with my colleague and friend Mariolina Eliantonio, whose energy and drive remain a continuous source of awe and inspiration. Many others at the Faculty of Law have also contributed to making the past four years the good time that they were. Tanja van der Meer, Mark Seitter, Antonia Waltermann, as well as 
Jaap Hage and his (though he would probably oppose the use of the possessive pronoun) philosophy group played no insignificant part in this.

While a PhD researcher is of course supposed to focus on completing his thesis, I took tremendous pleasure in teaching - certainly a trait I inherited from my parents - and I always found it an extremely rewarding distraction from my research. I would like to thank my students for the good time I had as a tutor and lecturer.

Despite all due and necessary romanticisation with which I can now finally look back, my PhD time has not only been nice and easy. For all their help and support whenever it was not, I am grateful beyond words to my friends, in particular to Jule Winkler and Laura Brehmer.

Finally and most importantly, I would never have been able to complete my doctorate without the love, patience, continuous support and ceaseless encouragement of my fiancée, Danielle. Thank you!

Sascha Hardt

Maastricht, July 2013 


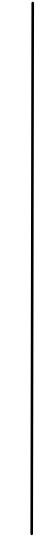

\section{TABLE OF CONTENTS}

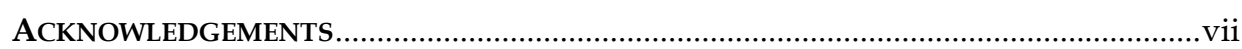

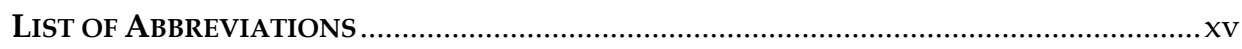

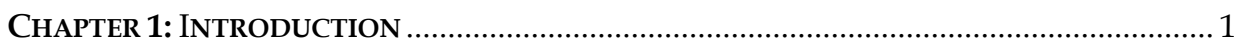

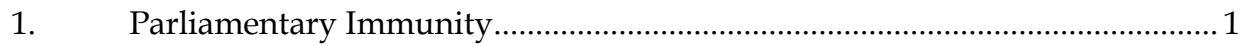

1.1. The Relevance of Parliamentary Immunity ............................................... 1

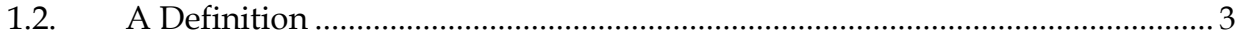

1.3. Two Forms of Immunity: Non-accountability and Inviolability .................... 4

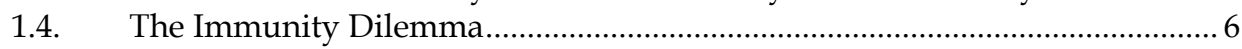

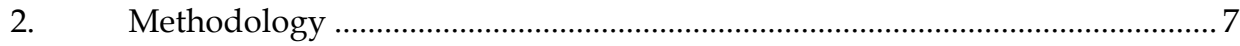

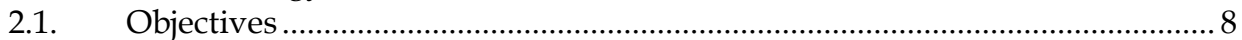

2.1.1. Understanding Parliamentary Immunity in Context..................................... 8

2.1.2. Differences and Commonalities .................................................................. 9

2.1.3. Trends and Developments............................................................................ 9

2.2. Methodological Challenges and Choices ................................................... 10

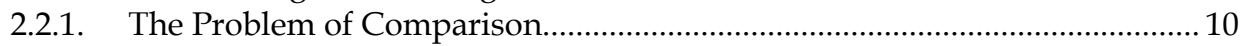

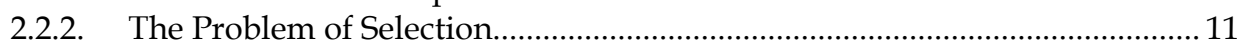

2.2.3. The Choice of the UK, France and the Netherlands as Case Studies ............ 12

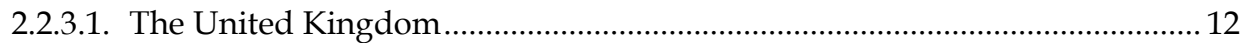

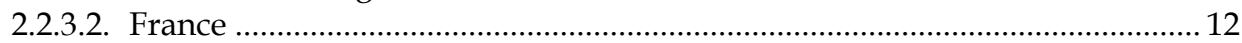

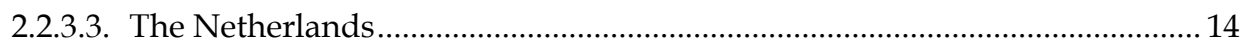


1. Introduction

2. Parliamentary Immunity and the ECHR

2.1. The Relevance of ECtHR Case Law: Interpretative Effects ............................ 18

2.2. ECtHR Case Law on Parliamentary Immunity ........................................... 19

2.2.1. Article 6 of the Convention: Access to Court .................................................... 20

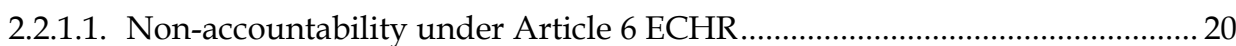

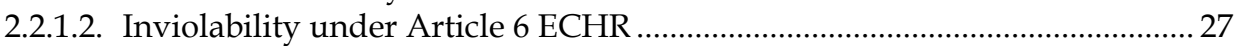

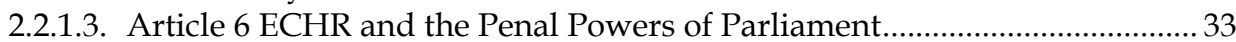

2.2.2. Parliamentary Immunity and Freedom of Expression: Article 10 ECHR..... 35

2.2.2.1. Freedom of Expression for Parliamentarians outside Parliament................. 36

2.2.2.2. Freedom of Expression: Speaking about Parliamentarians............................ 39

2.3. ECtHR Case Law on Parliamentary Immunity: Conclusions ......................... 41

3. The Immunity Regime of the European Parliament ......................................4 43

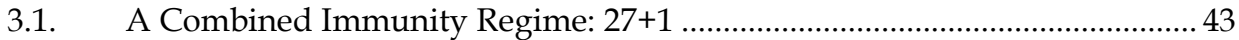

3.2. A Discriminatory System ........................................................................... 44

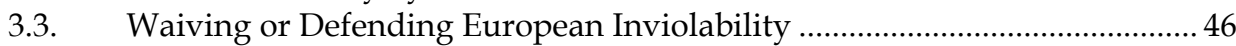

3.4. The CJEU and the Scope of European Non-accountability .......................... 49

3.5. The Immunity System of the European Parliament: Conclusion ................... 53

4. Concluding Remarks on Parliamentary Immunity in Europe........................53

Chapter 3: PARliamentary PRIVILEge IN THE United KingdoM ............................ 55

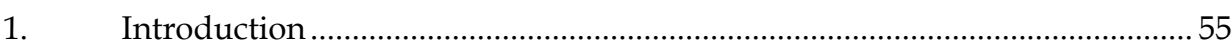

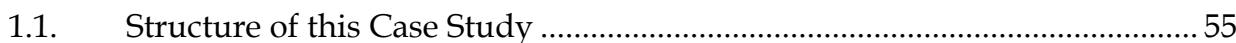

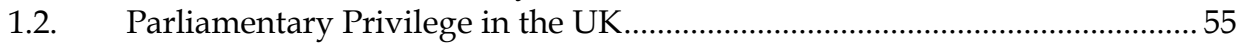

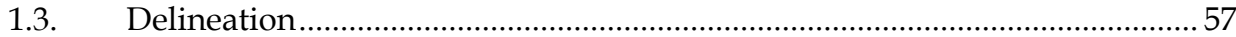

2. The History of Parliamentary Privilege ….................................................... 58

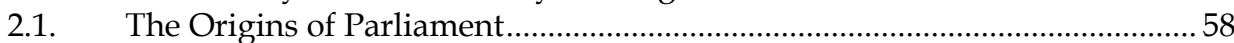

2.2. Historical Origins and Development of Privilege ................................................. 61

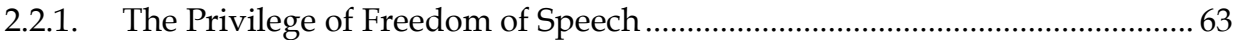

2.2.2. The Privilege of Freedom from Arrest and Molestation................................... 65

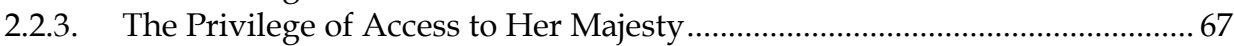

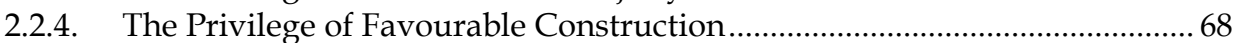

2.2.5. The Privilege of the House of Commons to Provide for its own

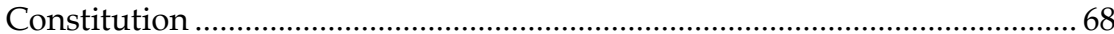

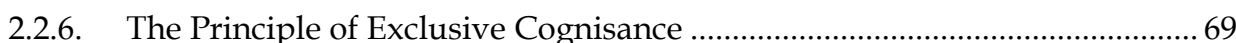

2.3. The House of Lords and the Privileges of the Commons ................................ 72 
3. Demarcating Exclusive Cognisance: Lex Parliamenti and Lex Terrae ............. 74

3.1. A Categorisation ........................................................................................ 75

3.2. The Evolution of the Relationship between Lex Parliamenti and Lex

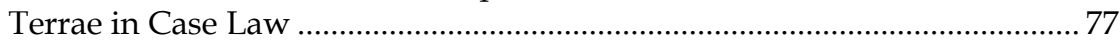

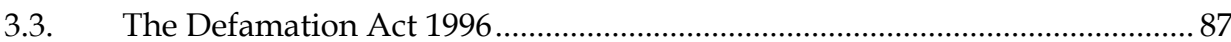

3.4. The Parliamentary Expenses Scandal and R v. Chaytor: The End of

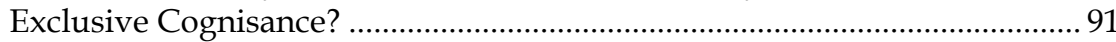

3.5. Lex Parliamenti and Lex Terrae: Conclusions................................................... 95

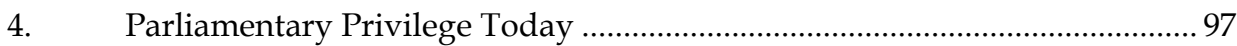

4.1. The Modern Perception of Privilege............................................................... 97

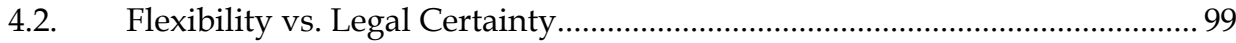

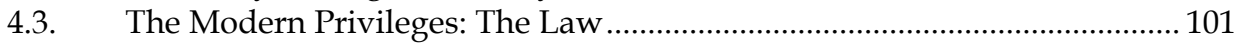

4.3.1. The Privileges ex Article 9 of the Bill of Rights 1689 ..................................... 102

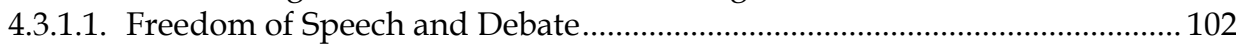

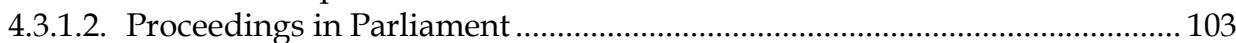

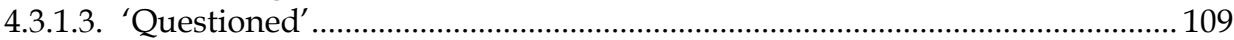

4.3.1.4. 'Place Out of Parliament' .................................................................................. 111

4.3.1.5. Recent Developments and the Future of the Article 9 Privileges ................... 113

4.3.2. The Privilege of Freedom from Arrest ........................................................... 119

4.3.3. The Enforcement of Privilege: Penal Powers of Parliament.......................... 121

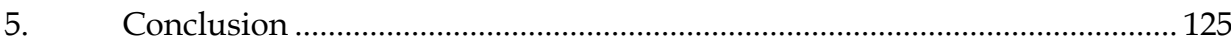

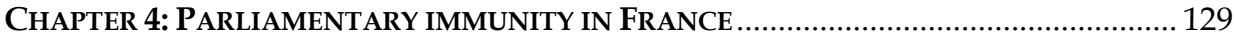

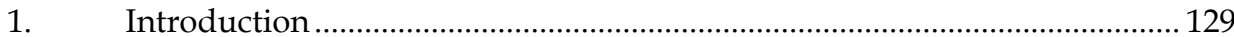

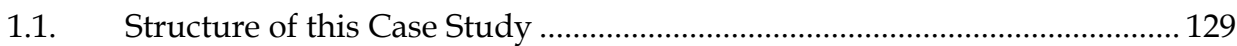

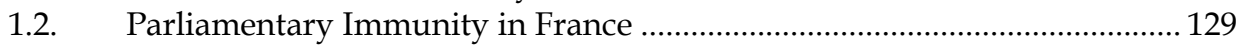

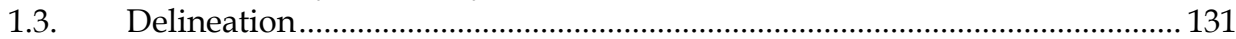

2. The History of Parliamentary Immunity in France ...................................... 132

2.1. The Concept of Parliament in Pre-revolutionary France .............................. 133

2.1.1. Representative and consultative assemblies in pre-revolutionary France. 133

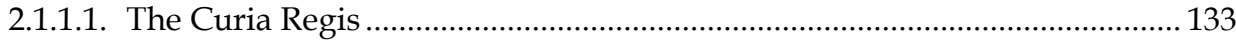

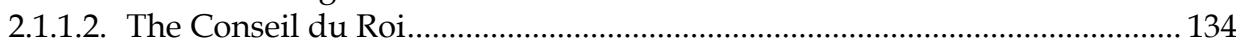

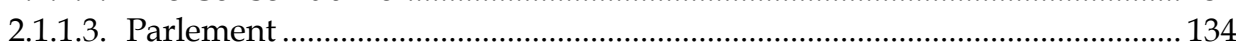

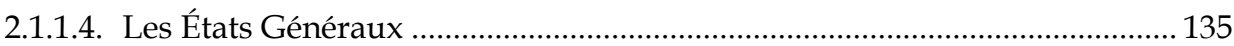

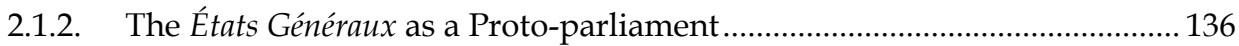

2.2. The Emergence of Immunity in the Revolution.......................................... 138

2.2.1. Minimal Privilege under the Ancien Régime ................................................ 138

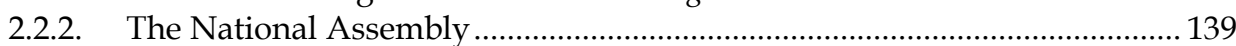

2.2.3. The Earliest Immunity Provisions ................................................................... 139

2.2.4. Two Possible Interpretations of the Emergence of Immunity ...................... 144 
2.3. The 'Waltz of Constitutions'

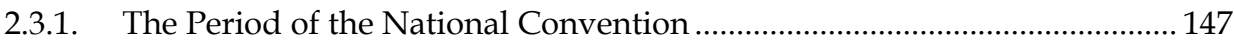

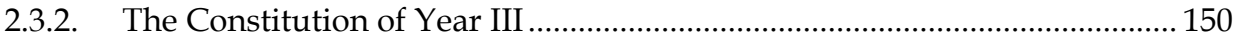

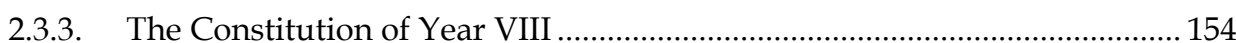

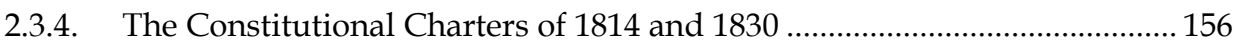

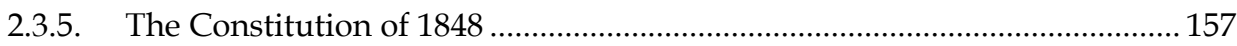

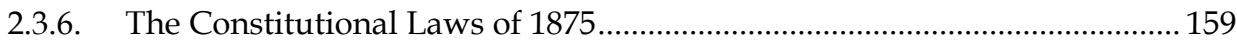

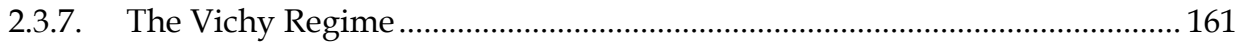

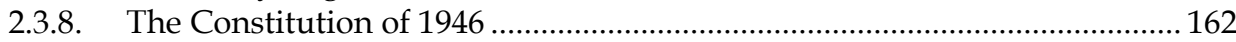

2.4. The History of Parliamentary Immunity in France: A Summary Picture .. 164

3. Theoretical Foundations of Parliamentary Immunity ................................. 165

3.1. The Significance of Constitutional Theory …................................................ 165

3.2. The Justification of Parliamentary Immunity in Classical Theory after

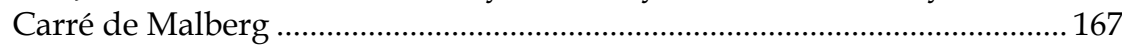

3.2.1. National Sovereignty and Representation................................................ 167

3.2.2. Parliamentary Immunity as a Corollary of the Representative Mandate... 172

3.2.3. Popular vs. National Sovereignty: Constitutional Text and Reality ........... 177

3.3. Theoretical Foundations: A Summary Picture ................................................ 180

4. The Immunity Regime of the Fifth Republic .............................................. 181

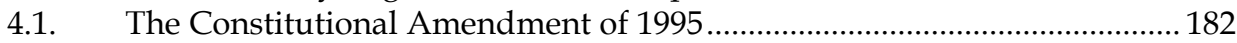

4.2. The Scope of Non-accountability and Inviolability ..................................... 183

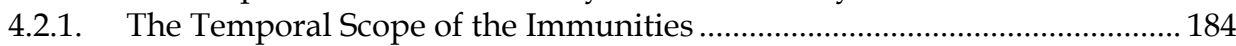

4.2.2. The Personal Scope of the Immunities ........................................................... 186

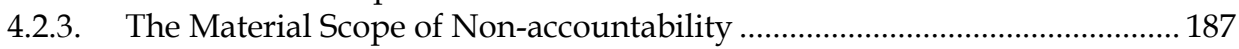

4.2.4. The Material Scope of Inviolability .............................................................. 190

4.3. Procedures for Lifting Inviolability and for the Suspension of Detention or Prosecution................................................................................................... 192

4.3.1. The Procedure for Lifting Inviolability ......................................................... 192

4.3.2. The Procedure for the Suspension of Detention and Measures of

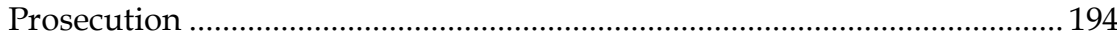

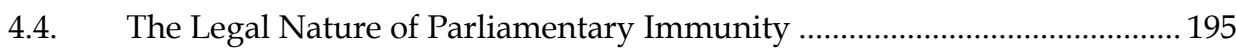

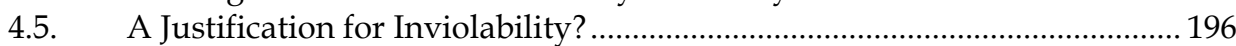

4.6. The Immunity Regime of the Fifth Republic: A Summary Picture .............. 197

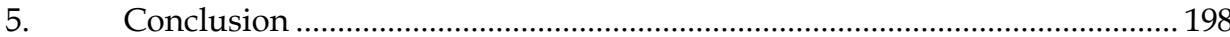

CHAPTER 5: PARLIAMENTARY IMMUNITY IN THE NETHERLANDS ................................ 201

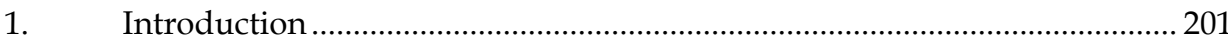

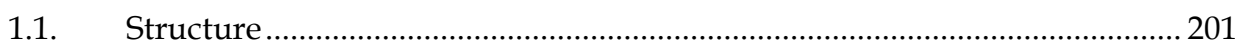

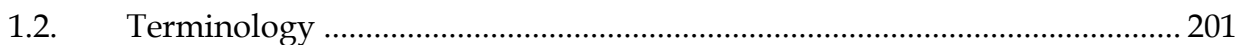

1.3. Parliamentary Immunity in the Netherlands ............................................... 202 


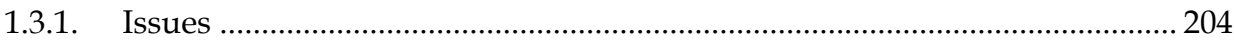

1.3.1.1. Historical Reasons for Limited Parliamentary Immunity ............................. 204

1.3.1.2. How Limited is Dutch Parliamentary Immunity in Reality? ....................... 205

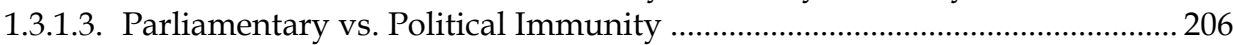

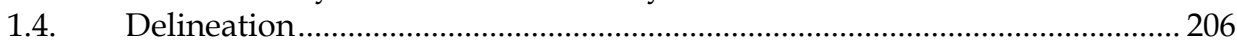

2. The History of Parliamentary Immunity in the Netherlands ..................... 207

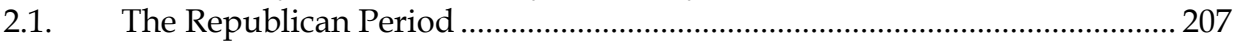

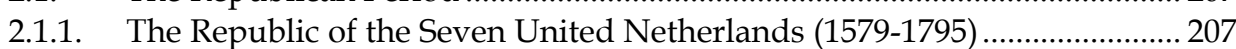

2.1.2. The Earliest Immunity Provisions in Holland ................................................ 210

2.2. The Batavian and French Period: 1795-1814 _...................................................... 214

2.2.1. The Batavian Republic................................................................................... 214

2.2.1.1. Immunity under the Constitution for the Batavian people of 1798 ........... 215

2.2.1.2. No Immunity under the Batavian Constitutions of 1801 and 1805 ............. 217

2.2.2. The Kingdom of 1806 and the French Annexation ...................................... 219

2.3. The Kingdom of the Netherlands 1814/15-1848 ......................................... 220

2.3.1. 'Enlightened Absolutism' and a Weak Parliament ...................................... 220

2.3.2. Inviolability for Crimes in Office: Indirect Freedom of Speech? ................. 222

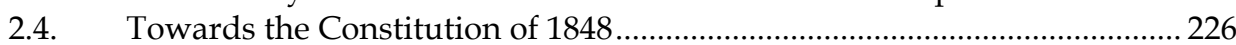

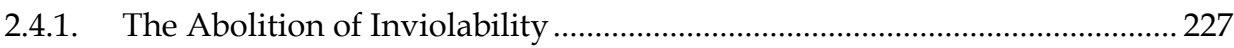

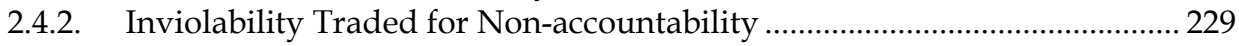

2.4.3. The Disputed Scope of Non-accountability ................................................. 231

2.5. More Non-accountability and Less Inviolability: A Negative

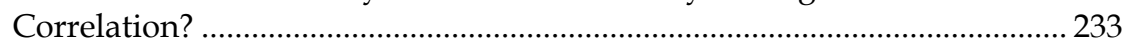

2.6. Developments during the $20^{\text {th }}$ Century ...................................................... 234

3. The Dutch Immunity System Today …....................................................... 241

3.1. The Scope of Non-accountability ex Article 71 of the Constitution ............. 241

3.1.1. Personal Scope................................................................................................. 242

3.1.1.1. Members, Ministers, Secretaries of State......................................................... 242

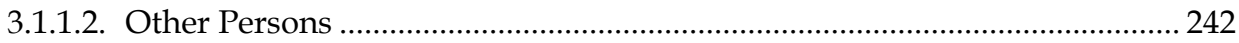

3.1.1.3. Can the State be Held Liable Instead? ............................................................ 246

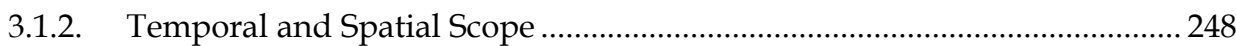

3.1.2.1. No Spatial Privilege ....................................................................................... 248

3.1.2.2. Non-accountability for the Duration of the Meeting only …........................ 248

3.1.3. Material Scope .......................................................................................... 249

3.1.3.1. No Limitations with Regard to the Content of Utterances Covered by Non-accountability .................................................................................... 249

3.1.3.2. No Immunity for 'Private' Publications, even if Identical to Protected

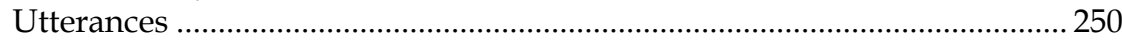

3.1.3.3. All Forms of Legal Action are Barred......................................................... 252

3.2. The Disciplinary Powers of the Chambers .................................................. 253

3.3. The Immunity Dimension of Article 119 of the Constitution ........................ 254

3.3.1. A Hypothetical Potential................................................................................... 255

3.3.1.1. Crimes Committed in Office (Ambtsmisdrijven) ......................................... 255

3.3.1.2. Does this Procedure Amount to Inviolability?............................................. 257 
3.4. Wilders and Beyond: A Case for Broadening Immunity? ............................. 259

3.4.1. The Prosecution of Geert Wilders ................................................................ 260

3.4.2. Parliamentary vs. Political Immunity ............................................................. 261

3.4.2.1. Freedom of Speech for Politicians in Public Political Debate........................ 261

3.4.2.2. Does Parliamentary Immunity Offer a Solution? ........................................... 264

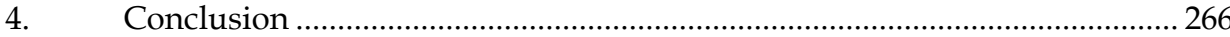

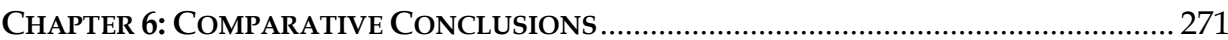

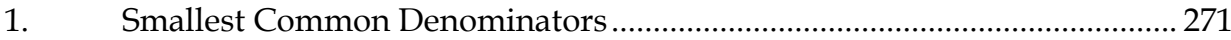

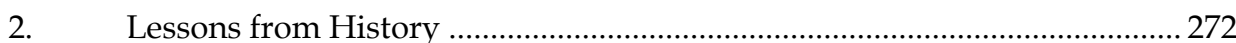

2.1. A Summary of the Historical Origins of Parliamentary Immunity............. 272

2.2. Freedom of Speech as the Epitome of Parliamentarianism.......................... 275

2.3. Inviolability as a Secondary Immunity ..................................................... 276

3. Theory and Parliamentary Immunity ......................................................... 278

3.1. The Justification of Parliamentary Immunity in Constitutional Theory .... 278

3.2. Constitutional Theory has a Conservative Effect ......................................... 280

4. The State of Material Immunity and Developments .................................... 281

4.1. Parliamentary Immunity in the UK, France and the Netherlands:

Material Similarities and Differences ........................................................... 281

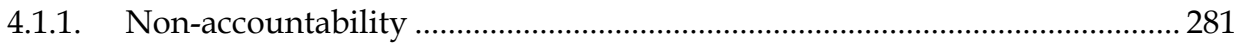

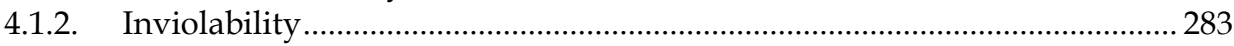

4.1.3. The Case of the Netherlands: Towards Political Immunity? ......................... 284

4.2. The Immunity of the European Parliament..................................................... 285

4.3. ECtHR and CJEU: A Functional Approach Towards Parliamentary

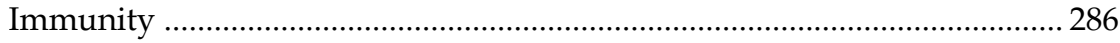

4.4. Do National Systems Develop in a 'Functional' Direction? ......................... 287

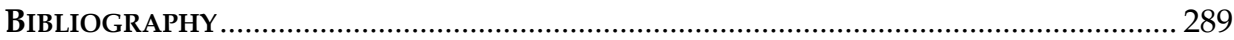

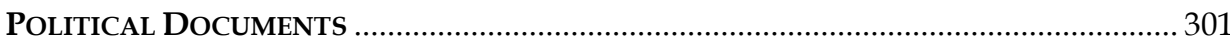

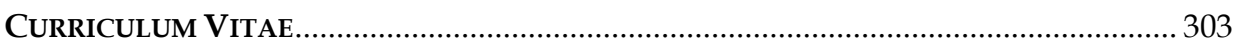




\section{LIST OF ABBREVIATIONS}

\begin{tabular}{|c|c|}
\hline CJEU & Court of Justice of the European Union \\
\hline CSP & Standards and Privileges Committee \\
\hline CSPL & Committee on Standards in Public Life \\
\hline ECHR & European Convention of Human Rights \\
\hline ECJ & European Court of Justice \\
\hline ECtHR & European Court of Human Rights \\
\hline $\mathrm{EP}$ & European Parliament \\
\hline EU & European Union \\
\hline ICERD & $\begin{array}{l}\text { International Convention on the Elimination of all Racial } \\
\text { Discrimination }\end{array}$ \\
\hline $\mathrm{MeP}$ & Member of the European Parliament \\
\hline MP & Member of Parliament \\
\hline TEC & Treaty establishing the European Community \\
\hline TEU & Treaty on European Union \\
\hline UK & United Kingdom \\
\hline
\end{tabular}



Chapter 1

\section{INTRODUCTION}

\section{Parliamentary Immunity}

\subsection{The Relevance of Parliamentary Immunity}

Among scholars, law students and laypersons alike, the most common response to hearing of the topic of this research project was something in the vein of 'what an obscure topic - but interesting!'. Therefore, it is perhaps in order to explain the relevance of parliamentary immunity as a research subject. Why should we want to investigate parliamentary immunity? Why is it important? There are essentially two reasons, one of a practical nature and one more abstract. First, even though parliamentary immunity is only rarely in the spotlight of scholarly - let alone public - attention, whenever it is it gives rise to legal and political questions which evade an easy, superficial answer. Is it fair and just to make parliamentarians immune? If so, to what extent and for which purpose? Individual cases often reveal a conflict of rights, since immunity means that the law is not applied to the immune person, which may limit the rights of others. A good understanding of parliamentary immunity is necessary to assess and solve this conflict. More in the abstract, parliamentary immunity touches the very core of constitutional law. Immunity rules are intimately linked to the basic setup and the idea of the democratic state, to the separation of powers, the concept of representation, the rule of law and human rights. Investigating parliamentary immunity therefore both requires and advances our understanding of wider constitutional law.

According to broad consensus, the raison d'être of parliamentary immunity is to protect parliament, the central institution of modern representative democracy, from undue external influence. Elected representatives, who collectively personify the public will and translate it into the laws which govern our lives, need to be able to debate freely in parliament and to discharge their mandate independently. They must not fear politically motivated prosecution or other forms of obstruction of the parliamentary process. This is what immunity tries to achieve by the partial exemption of members of parliament from the application of the law and the ordinary course of justice. Normally, parliamentarians cannot be prosecuted or tried for statements made in parliament. Often, they can only be criminally prosecuted 
and arrested with the authorisation of parliament. Sometimes, immunity even prevents civil action against parliamentarians.

Though usually met with little appreciation in public opinion, parliamentary immunity is deeply engrained in the constitutional systems of most states in the world. Virtually all states which have a parliament also provide for a system of parliamentary immunity. ${ }^{1}$ Nevertheless, specific legal research on the matter is relatively scarce and in most of the general literature on constitutional law parliamentary immunity appears as an obscure and marginal subject. That this is regrettable is easily illustrated by looking at concrete cases in which parliamentary immunity is at issue.

In 1996, the British MP Michael Stern delivered a speech in the House of Commons in which he addressed certain problems with public housing in his constituency. In the course of this speech, he disclosed the full name and address of A., one of his constituents, about whom he went on to make the most injurious statements. Mr Stern referred to A. and her children as 'neighbours from hell' and accused them of anti-social behaviour, littering, loitering, even prostitution. The parliamentarian had, however, never actually been in personal contact with A.; his allegations, which she strongly denied, were merely based on hearsay. Several newspapers picked up on this public slur in parliament and reported on the 'neighbours from hell'. As a result, A. and her children became the victims of racial abuse, hate mail and threats which eventually forced them to leave their home and neighbourhood. A. tried to seek legal redress from Mr Stern, but her attempt to sue the parliamentarian for defamation failed, since he was protected by parliamentary privilege. The European Court of Human Rights (ECtHR), to which A. finally complained, found that the absolute protection of statements in parliament, however injurious to the applicant, constituted a limitation to the rights of access to court that was justified as necessary in a democratic society. ${ }^{2}$

Was $A v$. the UK decided correctly? And if so, how far does the necessity to protect parliament go? To what extent is the curtailment of the rights of citizens an acceptable price for this protection of parliament? Should the protection of immunity extend to statements made outside parliament or even to criminal acts, other than utterances? After all, parliamentarians are today not only lawmakers but also important public figures with considerable media presence and a decisive influence on the course and content of societal debate. In order to be politically successful, members of parliament must disseminate and discuss their ideas and political agenda in public. What parliamentarians say and do is widely noticed, also beyond the immediate context of parliamentary debate and the legislative process. But do extra-parliamentary statements deserve equal immunity?

In 2007, the Dutch right-wing parliamentarian Geert Wilders published a newspaper article in which he referred to the Qu'ran as a 'fascist book' and compared it to Hitler's Mein Kampf. He also released the anti-Islamic film Fitna and

1 With very few exceptions, $c f$. Inter-Parliamentary Union, Parliamentary Immunity (draft background paper), Geneva, September 2006. For a list and summary of most existing systems of immunity, see also Maingot 2010.

2 A. v. The United Kingdom, ECHR 17 December 2002, App. No. 35373/97. 
made a number of public statements in which he demanded a stop to Muslim immigration to the Netherlands. Since Dutch parliamentary immunity does not protect, it was possible for him to be prosecuted and tried for insultation, incitement to hatred and incitement to discrimination. Wilders was finally acquitted of all charges, but the fact that he, an elected representative of the people, could be prosecuted for his public statements sparked some debate as to whether the limited Dutch immunity system provides adequate protection to parliamentarians speaking outside parliament. Thus, do the Netherlands need a higher level of immunity?

$A v$. the UK and Wilders's case are just two examples of the important legal and, not least, political issues which arise in the context of parliamentary immunity. This study will show that the line between necessary protection and unjustified privilege is rather thin, and that this line is slowly but continuously shifting in the course of constitutional and societal development. It is the endeavour of this study to trace this shift, to understand its causes and consequences and to develop a comprehensive view of parliamentary immunity that cuts across national borders.

\subsection{A Definition}

It is not easy to reach an exhaustive definition of the concept of parliamentary immunity that covers all of its possible forms and facets. In a very broad sense, parliamentary immunity is a legal instrument which inhibits legal action, measures of investigation, and law enforcement in civil or criminal matters against members of the legislature.

In all immunity systems, one or more elements of this definition are implemented. Nevertheless, there are large differences between countries as regards the individual characteristics and the scope of parliamentary immunity. These differences do not only concern the outward effects of immunity - who is protected, and from what - but also its legislative design and legal nature. Where a member of parliament is 'immune' this can be the effect of very diverse causes. For example, a constitutional immunity clause may provide that the courts lack jurisdiction to hear civil claims or criminal complaints against parliamentarians. This results in a procedural bar which prevents the enforcement of the law, but in principle it does not affect the validity of a civil claim or take away the criminal nature of an act. Another possibility is that parliamentary immunity affects the legal status of the acts or utterances of a member of parliament, so that, for instance, statements made during a parliamentary debate are generally deemed not to be insulting and therefore cannot give rise to criminal proceedings. Often, the distinction between these two different avenues through which immunity can be achieved is merely a matter of interpretation. A certain 'immunity effect' which falls outside the above definition can also be reached more indirectly. In an example to which we will later return in our discussion of immunity under the European Convention of Human Rights (ECHR), the publication of potentially harmful information about a person's private life was a criminal offence, and the fact that the victim was a member of parliament constituted a seriously aggravating circumstance. In this case, the 'immunity effect' does not relate to legal action against a parliamentarian, but to his general status before the law. 
While different legislative options are used to achieve immunity, its general purpose is always to enable the legislature to carry out its constitutional tasks without undue external interference. Historically, parliamentary immunity as a legal institution has been introduced to shield the legislature from, in particular, the executive. Our historical analyses of three European systems will show that this was necessary at times when the role and powers of parliaments was still frequently a matter of fierce - and sometimes outright violent - dispute. However, the independence of parliament also had to be asserted vis-à-vis the judiciary, which often was (and sometimes is) institutionally linked with the executive, or can be instrumentalised in politically motivated legal action. It would be wrong to believe that all of these struggles are merely a matter for history, even though the nature of disputes between the legislature and the other two branches of power has changed considerably over time. Today, the possibility of conflict between parliament and the media or private parties also adds to the need of the legislature for protection through parliamentary immunity.

\subsection{Two Forms of Immunity: Non-accountability and Inviolability}

As explained above, parliamentary immunity can take many different shapes. It must therefore be understood as an umbrella term, an overarching concept which denotes all legal instruments that have the effect of rendering members of parliament immune. For a good understanding of different immunity systems, it is indispensable to introduce one very important terminological subdivision within this overarching concept: the two main forms of parliamentary immunity are nonaccountability and inviolability.

'Non-accountability' primarily means freedom of the parliamentary vote and freedom of speech in parliament or in a parliamentary context. This is the most ubiquitous form of parliamentary immunity. Under non-accountability, parliamentarians may not be held legally accountable for their utterances and voting behaviour in the assembly to which they belong. Usually, non-accountability is materially and temporally absolute. This means that any kind of legal action is barred and that this bar is perpetual, applicable even after the end of their mandate. Lastly, non-accountability usually cannot be lifted by parliament nor renounced by an individual member.

The term 'inviolability' denotes immunity from legal action, detention or measures of prosecution or investigation outside the immediate scope of a member's activities in parliament. In short, inviolability covers matters which nonaccountability does not. Whereas non-accountability is a virtually universal feature of parliamentarianism, inviolability does not exist in all countries, and its exact scope differs considerably between systems. At times, inviolability can cover acts entirely unrelated to the parliamentary mandate, for instance traffic offences or theft. In other systems, a certain connection of an act with parliamentary activity must still be present for inviolability to apply. The effects of inviolability also differ: they range from the prohibition of arrest and detention to a general prohibition of all legal action, civil and criminal, and of all measures of investigation such as home 
searches or wiretapping. As opposed to non-accountability, inviolability is usually limited in time. It often applies only while parliament is in session and usually ends with the end of the parliamentary mandate. This means that it only has suspensive effect: even where inviolability bars the arrest or prosecution of a parliamentarian during the time of his mandate, he can be prosecuted and arrested after his term has ended, also for criminal acts committed during the mandate. In addition, inviolability may normally be lifted by parliament upon a request by the prosecuting authorities.

The distinction between non-accountability as an immunity for proper 'parliamentary affairs' and inviolability as an extra-professional immunity seems reasonably clear. However, one must bear in mind that this distinction remains a simplification, since the exact shape which both concepts may take in a given system is determined by the definition of specific terms, ${ }^{3}$ by material qualifications ${ }^{4}$ and by procedural factors. ${ }^{5}$ In effect, non-accountability and inviolability cannot always be clearly distinguished, especially if both concepts are not clearly separated in legislation, as is the case, for instance, in the United Kingdom. Nevertheless, the differentiation between these two forms of immunity is useful, as it enables us to identify two main traditions or models in the design of parliamentary immunity systems.

First, a variety of states (primarily those with a British colonial history) employ what may be called the Westminster type of parliamentary immunity, or privilege, as it is described in the Anglo-Saxon tradition. For all practical purposes, Westminster-type immunity is limited to non-accountability. Members of the British Parliament or other parliaments using Westminster-type immunity enjoy the privilege of freedom of speech: they may not be held legally accountable for the content of their statements in parliament, except, as the case may be, by parliament itself (an example being for contempt). Westminster-type systems do not usually provide for inviolability. Accordingly, the UK parliamentary privilege does not

3 A good example is Art. 9 of the English Bill of Rights 1689, in which the Lords and Commons 'do [...] for the vindicating and asserting their ancient rights and liberties declare: [...] that the freedom of speech and debates or proceedings in Parliament ought not to be impeached or questioned in any court or place out of Parliament'. Whether Art. 9 provides exclusively for non-accountability or also contains a small element of inviolability depends heavily on the definition of the phrases 'proceedings in Parliament' and 'any court or place out of Parliament'. Our case study of parliamentary privilege in the UK will show that Art. 9 is interpreted increasingly narrowly; its effects can therefore be said to be limited to nonaccountability.

4 One of the most common qualifications of inviolability is the exception of an arrest flagrante delicto, contained in most inviolability provisions. Another frequent qualification limits the scope of inviolability to acts which have some connection to the parliamentary work of the member, for instance in the Austrian Federal Constitutional Act, Art. 57(2) and (3).

5 The procedure for lifting immunity (inviolability) is particularly important in this respect. Depending on the institution competent to lift a member's immunity, the required majorities, and other factors, the lifting procedure makes inviolability de facto impenetrable in some systems. In others, the factual degree of protection afforded by immunity is relatively low because it is easily lifted. The lifting procedure can also account for different degrees of sensitivity to political majorities in the respective assemblies. 
feature freedom from arrest in criminal matters, whereas freedom from arrest in civil matters does formally exist but is of little practical relevance, as imprisonment in the civil process has long been abolished.

The other main model of parliamentary immunity follows what may be called the continental parliamentary tradition. It is employed by many states on the European continent and in parts of the world formerly dominated by France and other continental powers. It is sometimes also referred to as the French type of parliamentary immunity. In these systems, inviolability of members of parliament adds a second layer of protection to basic non-accountability. In effect, parliamentarians who enjoy the continental form of parliamentary immunity benefit from both non-accountability and inviolability: they may never be held accountable for what they have said in parliament. In addition, they may in principle not be deprived of their liberty without the authorisation of parliament. Depending on the respective system, and subject to qualifications, they may also not be prosecuted, or prosecution must be halted or suspended at the behest of parliament. There are (rare) cases of states with a continental legal system which do not grant their parliamentarians any form of non-accountability and whose immunity system therefore resembles Westminster-type parliamentary privilege. The Netherlands is the only such state in Europe.

\subsection{The Immunity Dilemma}

Systems of parliamentary immunity are anything but unchallenged. On the one hand, it is generally recognised in scholarly literature and constitutional practice that the protection which immunity affords is indispensable to the operation of democracy'. ${ }^{6}$ On the other hand, the scope of this protection is often perceived as excessive. Parliamentary immunity is criticised as facilitating corruption among parliamentarians and affording undeserved protection to libel and slander coming from the ranks of parliament. It is argued that parliamentary immunity enables representatives to 'pursue their own personal and political interests, over and above that which is made possible simply by their position of influence ${ }^{7}$ - a possibility which is seen as highly undemocratic and often leads to calls for immunity to be curtailed or even abolished. ${ }^{8}$

Case law and the parliamentary history of many states reveal that the legal institution of parliamentary immunity gives rise to one basic dilemma. Immunity is recognised as necessary to safeguard the proper functioning of parliament. Conversely, any legal immunity by definition creates exceptions to the normal application of the law and thereby limits the rights of citizens, who are prevented from enforcing their rights against members of parliament. This is problematic in the light of the principle of equality before the law. Even if we accept that the aim of

6 Observations of the Dutch Government, annexed to the judgment in A. $v$. The United Kingdom, ECHR 17 December 2002, App. No. 35373/97.

Wigley 2003, p. 23.

8 Such calls are often heard in debates surrounding alleged corruption cases. Cf. Özbudun 2005; Wigley 2009. 
parliamentary immunity is not to create a privileged caste of parliamentarians, but to protect the legislature as an institution, individual members of parliament are nevertheless the immediate beneficiaries of any immunity system. By virtue of immunity, their legal position is inevitably unequal to that of an 'ordinary citizen'. It is therefore in the nature of immunity to create exceptions to the principle of equality. Since the latter is one of the core constitutional values of any democratic society, any such exception is only acceptable insofar as it can be justified by another constitutional value, such as the functioning of the democratically elected legislator. The drafters of immunity rules are therefore faced with the challenge of carefully balancing the adverse effects of parliamentary immunity against the necessary protection of parliament which it is meant to afford.

It must be recognised that the two concerns - guaranteeing the necessary protection to parliament while safeguarding the rights of non-parliamentarians and preventing abuse of immunity - are not generally diametrically opposed to each other. Inequality can be justified in unequal situations and systems of parliamentary immunity for the most part are not designed to grant members of parliament absolute impunity. With the exception of the basic freedom of speech in parliament, which is normally absolute, immunity legislation and corresponding procedural rules usually do provide for the possibility to remedy transgressions of the law by members, either by lifting immunity and exposing the member to the ordinary course of law or by the use of disciplinary and penal powers of the relevant assembly itself. However, it is an important characteristic of parliamentary immunity that such remedies are at the discretion of parliament. Thus, they are not enforceable outside of parliament and against its will. In this sense, parliamentary immunity does create a privilege.

Instances of conflict between immunity and the rights of citizens are not insignificantly rare, nor insignificant in their impact: any failure to protect the proper functioning of parliament from undue external influence is a threat to a democratic constitutional system. Conversely, any failure to protect citizens' rights and parliament, as an institution, from abuse of the parliamentary mandate by its members carries the danger of undermining parliament's credibility and puts its legitimacy at jeopardy. This dilemma is therefore likely to persist. The question how different systems deal with the immunity dilemma it is the central underlying theme of this study.

\section{Methodology}

In short, the methodological approach of this book is to conduct a 'comprehensive comparative analysis' of the systems of parliamentary immunity of the United Kingdom, France and the Netherlands in a European context. It is comprehensive because the focus of this study does not lie exclusively on establishing the material content of the three immunity regimes and subsequently showing the differences and commonalities between them, but rather on understanding each of the three systems in depth. This includes the material immunity rules themselves, together with their historical origins and the way in which they relate to the constitutional setup of the three states and to overarching norms which exist in Europe. 
This approach results in three largely independent case studies that examine the national systems of the UK, France and the Netherlands in detail. These independent case studies are encased by an analysis of the 'European dimension' of parliamentary immunity and a comparative chapter. The latter will identify differences and commonalities between the three systems studied and draw conclusions with regard to common principles and possible trends in the development of parliamentary immunity.

In the following, an attempt will be made to justify the setup outlined above. In particular, the aims of this study will be addressed in more detail in order to justify the comprehensive approach. The methodological challenges of selection and comparison will also be discussed, with an explanation for the choice of the UK, France, and the Netherlands as case studies.

\section{1. $\quad$ Objectives}

At the risk of being accused of bad scientific style, it is useful, first of all, to explain what is decidedly not the aim of this study, and why not. A model solution for the immunity dilemma is not sought, nor is there an attempt to devise an ideal immunity system.

While better law is certainly the most desirable outcome of any legal research, we start this project under the hypothesis - or realisation - that it is impossible to draw a blueprint for an ideal system of parliamentary immunity which can be transposed from one national constitutional and political framework to another offhand. That this is a realisation rather than a mere hypothesis emanates not only from common sense, but also from historic experience. The Dutch case study will give the example of the Netherlands at the time of the Batavian Republic, whose constitution (and system of immunity) was largely taken over without adaptation from post-revolutionary France. The French immunity system hardly left any traces in the Netherlands and was quickly abandoned when the 'French period' came to an end.

While it may be true that all modern democracies share a basic stock of constitutional principles - the rule of law, the principle of equality, separation of powers and respect for human rights - it must be assumed that these principles merely create a rough normative framework for systems of parliamentary immunity. Any system of parliamentary immunity is so closely entangled with the individual circumstances of a country - its constitutional system, its legal tradition, its political culture and its history - that no model solution would be useful beyond the borders of one country.

\subsubsection{Understanding Parliamentary Immunity in Context}

It follows from the above that, even though parliamentary immunity as a legal institution is near-ubiquitous, its precise rules are by default system-specific. This does not only mean that drafting a universal blueprint for parliamentary immunity is a futile exercise - it also tells us what to do instead. In order to reach a better 
general understanding of the concept of parliamentary immunity, different immunity systems must be analysed in the context of their respective national background, and the similarities and differences which exist between them must be evaluated and understood. A thorough understanding of the factors which have shaped (and continue to shape) different immunity systems is a necessary first step before considering that parliamentary immunity can cross national borders, and before we can establish common parameters and potential for optimisation or harmonisation. Moreover, a thorough understanding is also a prerequisite for an assessment of the general - and not system-specific - criticism which parliamentary immunity has at times received ${ }^{9}$ and for an informed international debate about this near-universal component of parliamentarianism. The first aim of this study is therefore to arrive at a thorough and comprehensive understanding of the three immunity systems which we are going to examine. This means understanding the positive legal content of the respective immunity provisions and their application in practice, but it also means understating their historical development, their background in constitutional theory and the nature of their entanglement with the respective constitutional system as a whole. In addition, it is useful for a good understanding of parliamentary immunity to establish the existence and content of international norms by which the different national systems are bound or influenced. Such norms can be expected to exist in the European human rights system of the ECHR and within the European Union. Before entering into a close examination of national immunity regimes, we will therefore set the stage by examining the 'European dimension' of parliamentary immunity.

\subsubsection{Differences and Commonalities}

The reason why it is useful to examine several national systems of parliamentary immunity at the same time is that this will enable us to explore different legislative options and to find out whether, despite all the differences and particularities of the national systems, there is a set of common principles of immunity law. We hypothesise that this is the case among systems which adhere to the same constitutional values of equality, rule of law, separation of powers and human rights, as they are all faced with the same immunity dilemma. Identifying such principles will help, first of all, to create a benchmark for the critical assessment of immunity provisions despite the system-specificity which we have asserted. It can also provide the basis for future research and general thought about prospects of harmonisation or meeting international standards.

\subsubsection{Trends and Developments}

Finally, a third aim of this study, closely connected with the former two aims, but of a more practical nature, is to find out whether different systems of parliamentary

Cf. Maingot 2010. Maingot presents 'a case for the abolition of parliamentary inviolability' in all countries. 
immunity in Europe are generally developing in a similar direction. It will be interesting to see, for instance, whether there is a trend across systems towards a greater limitation of parliamentary immunity, and if so, what causes this trend. In this context, it will also be necessary to examine the effects of the European Convention on Human Rights (ECHR) and of the case law of the European Court of Human Rights (ECtHR) on parliamentary immunity, as well as the immunity system of the European Parliament. Both will add a genuine European perspective to our juxtaposition of three individual national case studies and thus provide them with a broader context.

\subsection{Methodological Challenges and Choices}

\subsubsection{The Problem of Comparison}

Why is it useful to compare systems of parliamentary immunity and what exactly does it mean to do so? It has already been asserted that a meaningful examination of the legal institution of parliamentary immunity - thus not only the positive law of a given system - requires comprehensiveness. We have to look into constitutional history, inquire into different areas of constitutional law which constitute the backgrounds for parliamentary immunity, and be aware of the socio-political situation of a country in order to reach the degree of understanding which is necessary to make comparison meaningful. This is so wherever the object of comparison is as such system-specific, as is clearly the case with parliamentary immunity.

The Oxford Handbook of Comparative Law describes this need for 'background studies' as the fundamental epistemological problem of comparative law. For legal comparison to become meaningful - that is to say more than a mere juxtaposition which illuminates material similarities and differences but which fails to explain and interpret them - we find it necessary to enter deeply into the 'partly autonomous reality created by the norms, doctrines and concepts of a legal system that do not necessarily find exact counterparts in another' ${ }^{\prime}{ }^{10}$ This is a slippery slope which, almost inevitably, makes it necessary for comparative legal research to study history. ${ }^{11}$ It is freely admitted that this also happens in this research project. However, this need not be a worrying concern, as it has been observed elsewhere that comparative studies which merely engage in listing similarities and differences of positive law are necessarily 'distinct [from the law itself], marginal and boring' ${ }^{12}$ We try to evade this, by making it the primary object of this study to understand how the general theme of parliamentary immunity is implemented in the particular

Jansen 2006, p. 307

Jansen 2006, p. 306

Glenn 2007, p. 91. Glenn states that comparative law, understood in this way, is distinct 'because it [is] constructed as separate from the law itself, as something which follows it (like the cigarette after sex, in the old movies'. This analogy is odd, yet clear: comparative law should address and understand the law itself, before addressing similarities and differences on a meta-level. 
context of the three individual systems we examine. However, of course the epistemological problem has an effect: the three case studies of which this study is mainly composed appear, first of all, as stand-alone analyses. An individual understanding of the respective systems of parliamentary immunity is built up. But we can make use of this characteristic in our comparison, since it enables us to find differences and commonalities not only on a material but also on a conceptual level, and to extrapolate principles and trends in development from the different national systems.

\subsubsection{The Problem of Selection}

It is clear that an examination of three systems of parliamentary immunity, however comprehensive, will in principle only produce results which are valid for these three systems. This is not problematic as long as we only aim to understand and compare these particular systems. However, as stated above, part of the declared goal of this study is also to see whether general conclusions can be drawn with regard to common principles and trends in the development of immunity legislation. Is it possible to reach such general conclusions by comparing only three systems? And if so, according to which criteria must these three systems be chosen?

From a logical point of view, the first question must be answered in the negative. However, one has to bear in mind that the findings which we hope to achieve can only be 'general' in the sense that they apply to states which are comparable with regard to some fundamental constitutional concepts, such as parliamentarianism, separation of powers, the principle of equality, the rule of law and the observance of human rights. As parliamentary immunity is narrowly intertwined with these concepts, general findings are of mutual relevance to all (or most) comparable states.

Concerning the choice of immunity systems for comparison, it is important that they are sufficiently different to cover the range of legislative options. It is therefore advisable to choose as case studies three immunity regimes which mirror the variety of existing systems. At the same time, the states in which these immunity regimes operate should be sufficiently comparable: they should be subject to the same human rights obligations and should not be too divergent with regard to their socio-political situation as 'established democracies'. ${ }^{13}$ Another important criterion for choosing our case studies is the accessibility of information and literature, both generally and in terms of language, to the author. This excludes many immunity systems which would otherwise certainly be of interest, such as those of the Scandinavian countries or Greece.

13 This is a troublesome concept in many ways. However, there is a noticeable difference between the scope of the parliamentary immunity of most states in Western Europe and states like Russia or Turkey, whose transition to democracy and parliamentarianism has either been relatively recent or particularly troubled. Including such systems in our comparison would mean that we have to take into account not only the historical differences which exist between them and Western European democracies, but also persisting differences in the political landscape and constitutional setup which makes them harder to compare. 
All of the above criteria are fulfilled by the United Kingdom, France and the Netherlands. In the following, the motives for this selection will become more evident.

\subsubsection{The Choice of the UK, France and the Netherlands as Case Studies}

\subsubsection{The United Kingdom}

The system of parliamentary privilege in the United Kingdom is a natural starting point for a comprehensive study of immunity systems. Not only is the Parliament of Westminster considered 'the mother of all parliaments',14 but its system of privileges dates back almost to the institutional origin of English legislature in the Middle Ages.

Age, however, is not the primary factor which makes the British system of parliamentary privilege worth considering in a comparative study. Several reasons are more compelling. Firstly, Westminster-type parliamentary immunity is unique in Europe in terms of its legal organisation and the legal system (common law and no codified constitution) in which it operates. ${ }^{15}$ In order to capture the variety of systems of parliamentary immunity, the United Kingdom is therefore an inevitable choice. Secondly, most states with a British colonial history adhere to a form of Westminster-type privilege, including the USA, Canada, Australia, New Zealand and India. In some Commonwealth countries, Article 9 of the Bill of Rights 1689 (which essentially provides for freedom of speech in parliament) is still in force as the basis of the most important privilege. Until recently, the British Privy Council still functioned as the highest judicial instance for some Commonwealth countries, thereby creating precedent and contributing directly to the development of parliamentary privilege in those countries. As a result, the British system of parliamentary privilege is one of the most important systems of parliamentary immunity in the world.

\subsubsection{France}

The choice of France as one of the case studies in this comparative project is justified by several considerations which, combined, make France a logical and very interesting subject in the context of comparative research on parliamentary immunity.

First of all, the level of protection offered to parliamentarians under the French system can be said to represent one of the 'extremes' on a comparative scale of immunity; the inviolability of members of the French National Assembly and Senate

14 This is not to say that it is the oldest existing parliament in the world; this title can probably be claimed either by the Icelandic Alpingi, founded in 930, or by the Isle of Man's Tynwald, which was founded a few decades later but has been continuously active ever since.

15 The Irish system of parliamentary privilege is modelled on the British one, but the powers and privileges of the Irish parliament are inscribed into the constitution. The same is true for the Maltese system 
stands in significant contrast to systems - such as that of the UK or the Netherlands - which do not offer this extra-professional layer of immunity for criminal acts unrelated to the exercise of the parliamentary mandate. ${ }^{16}$ For a comparative study with the aim of exploring and analysing the different legislative and constitutional options in the field of parliamentary immunity it is natural and indispensable to include a system which is located near the upper end of a scale of immunity protection.

Second of all, of course there are other countries on the European continent which offer similarly high, or even higher, levels of protection to their parliamentarians. ${ }^{17}$ However, France appears to be the most logical choice with a view to its comparability to the other case studies considered. As explained earlier, it is important that all three case studies are 'established democracies' and share a comparable socio-political situation - as opposed to countries where the precariousness or the general novelty of the current democratic system of government would have to be considered in an analysis of parliamentary immunity. The choice of France, the UK, and the Netherlands offers the possibility of a comparison between states whose socio-political circumstances are broadly similar.

Finally, like the UK, France has been both one of the historic forerunners in developing systems of parliamentary immunity and one of the largest colonial powers, with the result that its political and constitutional system has had a significant influence on those of many other states in the world, particularly in Francophone Africa. ${ }^{18}$

Apart from these factors, France's intrinsic value as a case study is very high, particularly in the light of its constitutional history and the extensive body of political and legal thought resulting from it. France has been described as a 'constitutional laboratory' in which 'all kinds of forms of government have been

16 This is still the case after the scope of inviolability has been significantly reduced by the amendment of Art. 26 of the constitution in 1995 (Loi constitutionnelle No. 95-880 du 4 août 1995).

17 Very high levels of protection under inviolability exist, for instance, in Russia and Turkey. Art. 98 of the Russian constitution provides that members of both chambers of the federal parliament may not be arrested (except flagrante delicto), detained, searched or personally inspected during the entire term of their mandate; while this provision does not bar prosecution, the lack of a limitation of inviolability to the duration of the parliamentary session makes the Russian inviolability regime appear more protective than its French counterpart. Likewise, the degree of protection enjoyed by members of the Turkish Grand National Assembly is significantly broader than that provided by the French inviolability system in that it even suspends the execution of final criminal sentences for the duration of the mandate. Interestingly, while the inviolability of Turkish parliamentarians may be lifted by the Assembly, it is explicitly prohibited for political party groups to 'hold discussions or take decisions regarding parliamentary immunity' (Art. 83 of the Turkish constitution).

18 In fact it has been argued that the Francophone states of Africa seem much less inclined to depart from their colonial constitutional heritage than their Anglophone counterparts, to the effect that ' $[\mathrm{m}]$ any Francophone African constitutional draftsmen [...] have continued to seek inspiration from and rely almost slavishly on what they perceive as the most reliable and unassailable constitutional model: the Gaullist Fifth Republic constitution and the timid amendments that have been made to it in the last fifty years'; Manga Fombad 2008. 
tried since $1789^{\prime} .{ }^{19}$ This constitutional volatility and the relative persistence with which parliamentary immunity, first introduced in the early days of the Revolution, has maintained its place in numerous different constitutional systems make the study of French parliamentary immunity worthwhile. However, the number of constitutions and forms of government France has known since 178920 also makes an in-depth analysis of all the historic immunity regimes impossible within the scope of this study. Therefore, the account of French constitutional history and historic immunity regimes given in this chapter can only serve as a descriptive framework of reference for the analysis of the theory and practice of parliamentary immunity in the modern French state of the Fifth Republic.

\subsubsection{The Netherlands}

A case study on the Dutch system of parliamentary immunity is a natural component of this research project. First, it is not mere coincidence that the idea for a comprehensive comparative study of parliamentary immunity was born in the Netherlands, where this book was written; nor is the time at which this idea was conceived. At first glance, the Netherlands seemed an unlikely country for controversy concerning immunity: the immunity of Dutch parliamentarians is very limited in comparison to that enjoyed by their counterparts in most other countries. As a sort of natural reflex, one would perhaps expect controversy in systems where immunity is deemed unfairly broad, where it gives the impression of creating an unduly privileged political class and raises politicians above the law. This can hardly be said of the immunity regime of the Netherlands, and so it has received little attention and sparked even less controversy for the duration of most of its history. In recent years, however, the Dutch immunity system has been the object of debate and controversy which have for a significant part been stirred by certain remarks by the far-right politician Geert Wilders. Wilders was acquitted of allegations of, among others, incitement of racial hatred, but the fact that he could be prosecuted and tried for such statements in the first place sparked discussion on parliamentary immunity: as the utterances in question were made outside parliament and thus did not fall within the scope of non-accountability, Wilders was not immune. This gave rise to the question whether the Dutch system of immunity is adequate, or whether it would be possible and desirable to broaden its scope. This question - which in itself distances the Netherlands from most other countries, where public opinion barely shows much sympathy for the existing immunity regime, let alone for expanding it - has put parliamentary immunity in the public and academic spotlight. Important also in inspiring this comparative study is the attention which parliamentary immunity recently received in the Netherlands after having led 'a dormant existence' 21 for much of the $20^{\text {th }}$ century.

Vogel 2008, p. 11

Vogel notes that, depending on the definition one applies, between 1789 and 1958 France has seen 13 or 15 constitutions. Vogel 2008, p. 12

Nehmelman 2011, p. 355. 
Apart from this, however, the choice of the Netherlands as one of our three case studies is given merit by virtue of the difference of its immunity system from those of the other two countries considered. Materially, Dutch parliamentary immunity is relatively similar to Westminster-type parliamentary privilege. However, it is organised in an entirely different way and follows a different rationale which is historically closer to the continental legal systems, in particular that of France, by which it was influenced during the Napoleonic period. Yet, the Dutch immunity regime is much more limited than the French one because it does not feature inviolability - or only in a very rudimentary form, as will be shown. It is especially this difference from the immunity regimes found in other, closely related continental constitutional systems which makes the Netherlands highly worthy of a case study. The institutional setup and constitutional position of the Dutch StatesGeneral today does not differ from that of other parliaments to such a degree that would explain, from the outset, a much lesser need for the protection of members of parliament than found in the other two states considered in this study. By examining the Dutch immunity system, we can therefore hope to learn more about the legislative rationale, the practical functioning and the potential pitfalls of a system at the lower end of the 'immunity scale'. 

Chapter 2

\section{THE EUROPEAN DIMENSION OF PARLIAMENTARY IMMUNITY}

\section{Introduction}

Parliamentary immunity belongs to the core of constitutional norms which regulate the powers and functioning of the central institutions of a state. This makes immunity primarily a national phenomenon. Nevertheless, it also has an international dimension, within which we can distinguish two levels. On a general international level, immunity systems across the world share certain characteristics and mostly follow one of two leading patterns - that of Westminster-type parliamentary privilege or that of French parliamentary immunity. In essence, systems that follow the former pattern provide for absolute freedom of speech in parliament and protect parliamentary proceedings, whereas systems that follow the French model also provide for an additional 'immunity layer' of freedom from arrest or prosecution. In very broad terms, these international commonalities exist because the general constitutional structure and legal system of many states have been influenced by either the continental European model or the British model.

There is generally no normative force in recognising similarities between immunity regimes on a broad, international level, even though a comparison of the positive immunity rules of all or most countries in the world will certainly reveal a 'legislative range' and allow some (careful) conclusions about minimum and maximum standards of immunity. These conclusions might be meaningful from an empirical point of view, but they will lack any normative character. This is clearly different on a European level, due to two factors. On the one hand, the various systems of parliamentary immunity which exist in Europe do not only display many similarities (along with many differences), they are also subject to common binding norms which stem from the European human rights system. All European states except Belarus, Kosovo and the Vatican State are contracting parties to the European Convention on Human Rights (ECHR). Their immunity systems therefore must comply with the provisions of the Convention and with the standards developed in the case law of the European Court of Human Rights. It is therefore indispensable to examine this case law in the hope to distil from it a certain normative essence for parliamentary immunity in Europe. 
The second factor through which the systems of parliamentary immunity of many European states are linked more closely with each other than they might be in a purely international context is the existence of the European Parliament (EP). The latter's own immunity regime combines the systems of all Member States of the European Union, as we will see below. While the immunity system of the European Parliament does not have a direct normative bearing on those of the Member States, it is nevertheless highly interesting to take a closer look at this system: after all, it is the immediate result of an attempt (by the six founding members of the European Communities) to find a 'common approach' to parliamentary immunity and cast it in a legislative form. Moreover, the (rare but) relevant case law of the Court of Justice of the European Union (CJEU) as the Union's highest judicial authority may allow - again, careful - conclusions about a common European understanding of parliamentary immunity.

\section{Parliamentary Immunity and the ECHR}

\subsection{The Relevance of ECtHR Case Law: Interpretative Effects}

The majority of cases in which the European Court of Human Rights (ECtHR) has pronounced itself on parliamentary immunity did not directly concern any of the selected states of our case studies. In order to determine in how far ECtHR case law is nevertheless relevant in these states, and in order to clarify the general importance of this case law for all contracting parties to the Convention, it is useful to recall the interpretative effect of Strasbourg judgments.

Pursuant to Article 1 of the ECHR, the High Contracting Parties undertake to 'secure to everyone within their jurisdiction the rights and freedoms defined in [...] this Convention'. Decisions of the Court do not have effect erga omnes and are in principle only binding on states which are parties to a particular dispute. ${ }^{1}$ However, the contracting states accept that ECtHR judgments also have general interpretative authority with regard to the content of the Convention rights. ${ }^{2}$ On the occasion of the High Level Conference at Interlaken in 2010, the state parties resolved to '[take] into account the Court's developing case law, also with a view to considering the conclusions to be drawn from a judgment finding a violation of the Convention by another state, where the same problem of principle exists within their own legal system $^{\prime}{ }^{3}$ The Court itself has also assumed this interpretative authority of its rulings on numerous occasions:

Art. 46(1) ECHR.

It is assumed that the res interpretata authority of the Court can be construed from Art. 1 in conjunction with Art. 19 of the Convention; cf. PACE Committee on Legal Affairs and Human Rights (AS/Jur) 2010, p. 3.

3 High Level Conference on the Future of the European Court of Human Rights, Interlaken Declaration, 19 February 2010, p. 3. 
The Court's judgments in fact serve not only to decide those cases brought before the Court but, more generally, to elucidate, safeguard and develop the rules instituted by the Convention, thereby contributing to the observance by the States of the engagements undertaken by them as Contracting Parties. ${ }^{4}$

Accordingly, the case law of the ECtHR with regard to parliamentary immunity is of general relevance, and its authority covers all parties to the Convention, including France, the Netherlands and the United Kingdom. The latter has, moreover, stipulated in section 2(1) of the Human Rights Act 1998 that its national courts must take ECtHR case law into account in the interpretation of Convention rights.

\subsection{ECtHR Case Law on Parliamentary Immunity}

There are essentially two categories of cases in the context of parliamentary immunity in which Convention rights are at issue. ${ }^{5}$ The first and most important category relates to the right of access to court under Article 6(1) of the Convention:

\footnotetext{
In the determination of his civil rights and obligations or of any criminal charges against him, everyone is entitled to a fair and public hearing within a reasonable time by an independent and impartial tribunal established by law. [...]
}

It is readily apparent that any form of parliamentary immunity bears much potential for conflict with this right, since immunity protects parliamentarians from legal action and thus bars access to court.

Within the category of cases relating to Article 6, three sub-categories can be found. First, citizens may be denied the possibility of (civil or criminal) legal action against a parliamentarian. This may happen, for instance, in defamation cases where the statements in question are protected by non-accountability. Second, and much less frequently, parliamentarians themselves may not be able to have their rights or criminal charges against them determined in court. This can be the case where a member of parliament is protected by inviolability without the possibility of an individual waiver and where parliament refuses to lift the member's immunity. The third sub-category of cases under Article 6 concerns the penal powers of parliament and their potential conflict with the requirement of an independent and impartial tribunal established by law.

$4 \quad$ Ireland v. United Kingdom, ECHR 18 January 1978, App. No. 5310/71, para. 154. The Court often reiterated this view, e.g. in Rantsev v. Cyprus and Russia, ECHR 7 January 2010, App. No. 25965/04, para. 197.

$5 \quad$ Alternative categorisations have been suggested, notably by M. Kloth in his very informative book (Kloth 2010). In his brief discussion of parliamentary immunity, Kloth does not distinguish between non-accountability and inviolability and discusses immunity only in the light of the right of access to court. He suggests that there are three categories of ECtHR case law on this aspect of immunity: (a) cases in which the content of statements in parliament is at issue, (b) cases in which the occasion on which the statements in question have been made makes it doubtful whether they are covered by immunity, and (c) cases in which parliament refuses to lift a member's immunity on his request. 
Along with cases concerning the right of access to court under Article 6 of the Convention, a second main category of case law in the context of parliamentary immunity concerns Article 10 of the Convention on freedom of expression. The main issue here is the question whether members of parliament, when speaking outside of actual debates in parliament, enjoy a wider freedom of expression than 'ordinary' citizens. We may anticipate at this point that this question is of particular interest in the Netherlands, where the prosecution of a right-wing parliamentarian for extra-parliamentary hate speech and insult has led to debates on whether the special position of politicians in society merits a greater freedom of speech than that which other citizens enjoy (see Chapter V).

The above categorisation will guide us through a discussion of the case law of the European Court of Human Rights with regard to parliamentary immunity on the following pages. Case law which relates to Article 6 of the Convention will be addressed first, followed by cases under Article 10. Finally, the standards for parliamentary immunity created in ECtHR case law will be presented in a set of conclusions.

\subsubsection{Article 6 of the Convention: Access to Court}

\subsubsection{Non-accountability under Article 6 ECHR}

The issue of access to court was first dealt with by the old European Commission of Human Rights in three admissibility decisions on applications complaining that parliamentary immunity had violated the applicants' rights under Article 6 of the Convention. ${ }^{6}$

The first of these decisions was $X v$. Austria, in which the Commission decided in 1969 that the application was manifestly ill-founded, considering that all contracting states regarded parliamentary immunity as an important constitutional principle from which they could not have wished to derogate by ratifying the Convention. ${ }^{7}$

Seven years later in 1976, the applicant in Agee v. UK was a former CIA agent who had published a book about his work for the Agency and was planning another book on its activities. He was refused re-entry into the UK on grounds of having had regular contacts harmful to national security. These allegations, which the applicant regarded as defamatory, had also been raised by the Home Secretary in the House of Commons. The applicant complained that his right to access to court was violated, since he was barred by parliamentary privilege from suing the Secretary for defamation. The Commission declared the application inadmissible. ${ }^{8}$ Curiously, in Agee v. UK the Commission did not argue that parliamentary privilege constituted a justified exception to Article 6. Instead it held that, due to parliamentary privilege, the applicant had no 'civil right' under UK law to defend

Kloth 2010, p. 187-188.

X v. Austria, Commission Decision of 6 February 1969, App. No. 3374/76.

Agee v. the United Kingdom, Commission Decision of 17 December 1976, App. No. 7729/76. 
his reputation against statements made in parliament, and that Article 6 was therefore not applicable. In his recent book about immunities and the right of access to court, Matthias Kloth correctly argues that this line of reasoning is flawed, since, had it not been for parliamentary privilege, the applicant would certainly have had the right to sue. Accordingly, the Commission should have based its decision on the justification of privilege, rather than on the non-existence of a civil right to sue for defamation. ${ }^{9}$

Finally, the Commission's decision in Young $v$. Ireland concerned a neurosurgeon who had been unable to save a child with severe head injuries. After the death of the child, a member of the lower chamber of the Irish parliament made certain comments during a parliamentary debate which the doctor regarded as defamatory. He wanted to sue the parliamentarian for defamation but was barred from doing so by parliamentary privilege. This time, the Commission held that it was immaterial whether privilege constituted a procedural bar and therefore had to be assessed under Article 6(1) of the Convention or whether it limited a civil right and had to be assessed under Article 8: either way, privilege had to stand the test of legitimacy of aim and proportionality. Finding that parliamentary privilege aimed at facilitating free speech in parliament, and that it was proportional in the circumstances of the case, the Commission declared the application inadmissible.

The 'leading case' of the European Court of Human Rights on the issue of parliamentary immunity (or privilege) as an impediment to the right of access to court is $A v$. the United Kingdom. ${ }^{10}$ The case was brought by A., a former resident of a building owned by a public housing association in Bristol. In 1996, Michael Stern, then member of the Commons for the constituency of Bristol North-West, spoke in Parliament on the subject of municipal housing in his constituency. In the course of his speech, which was subsequently published in several national newspapers, he gave the full name and address of the applicant and made several highly injurious statements about the applicant without ever having been in direct contact with her. Among others, he referred to A. and her children as 'neighbours from hell'11 and accused them of causing severe nuisances for the whole neighbourhood by their 'asocial' lifestyle which involved littering the area, loitering, alleged 'drug activity' and, he implied, prostitution. The publication of A.'s name and address in conjunction with these allegations had severe adverse consequences for the applicant. After receiving threatening hate mail and suffering racial and other abuses, she 'ha[d] been put in considerable danger as a result of her name being released to the public', as was found by a report on racial harassment and attacks in her area. ${ }^{12}$ The applicant sought redress by writing to Mr Stern MP, whereupon she was informed by the Speaker's office that the parliamentary statements in question were protected by absolute privilege, 'however offensive it may be to the feelings or injurious to the character of individuals' ${ }^{13}$ Further to a letter to the Prime Minister,

Kloth 2010, p. 160-161.

A. v. The United Kingdom, ECHR 17 December 2002, App. No. 35373/97.

Ibid., para. 13

Ibid., para. 18

Ibid., para. 19 
she received a reply affirmative of the Speaker's assertion of absolute privilege. There was thus no avenue of legal recourse open to the applicant to bring charges of libel or defamation against her MP.

Hence, the principal question with which the Court was confronted in A. v. UK was whether or not the applicant's lack of access to legal recourse constituted a breach of Article 6(1) of the Convention or whether the necessity, in the public interest, of a solid scheme of parliamentary immunity constituted a justification for the limitation of the right of access to court. Before turning to this question directly, the Court briefly addressed the question of whether the matter at hand touched upon Article 6 at all, as UK domestic law does not provide for a civil right to the protection of a person's reputation in so far as it might be affected by statements made in Parliament. The Court noted that Article 6 could nonetheless be violated since parliamentary privilege constitutes a procedural bar to defamation claims, rather than a material defence to such claims. The Court thus dismissed the Commission's argumentation in Agee, which the Commission itself had already abandoned in Young. The Court affirmed the Commission's approach in Young by subsequently applying the test of legitimacy of aim and proportionality to the principal question of the case:

\begin{abstract}
The right of access to a court is not absolute, but may be subject to limitations. These are permitted by implication since the right of access by its very nature calls for regulation by the State. In this respect, the Contracting States enjoy a certain margin of appreciation, although the final decision as to the observance of the Convention's requirements rests with the Court. It must be satisfied that the limitations applied do not restrict or reduce the access left to the individual in such a way or to such an extent that the very essence of the right is impaired. Furthermore, a limitation will not be compatible with Article $6 \S 1$ if it does not pursue a legitimate aim and if there is no reasonable relationship of proportionality between the means employed and the aim sought to be achieved. ${ }^{14}$
\end{abstract}

The result of the Court's examination of whether the UK system of parliamentary privilege constitutes a legitimate and proportional limitation of the right to access to a court was that, indeed,

'[it] cannot in principle be regarded as imposing a disproportionate restriction on the right of access to a court as embodied in Article $6 \S 1^{\prime} .{ }^{15}$

In reaching this conclusion, the Court considered several arguments: First, parliamentary immunity appears to be a universal feature of parliamentary law in most signatory states and the British model of immunity is comparably narrow. ${ }^{16}$ Second, British privilege exists for the protection not of individual members of Parliament but of Parliament as a body; this underlines that it is indeed in the

Ibid., para. 74

Ibid., para. 83

This was confirmed by numerous third-party interventions in A v. the United Kingdom, see part IV of the judgment, letters A-H. 
general interest of democracy. Third, victims of a 'defamatory misstatement in Parliament' are not entirely without redress, since they can still petition the constituent MP for a remedy (as A. did by her letter to Mr Stern).

The first of these arguments holds true with regard to all states party to the Convention. The second argument, that privilege exists for the benefit of the institution and not the individual member, is in line with generally accepted constitutional doctrine and, to a large extent, with modern practice. Nevertheless, our analysis of parliamentary privilege in the UK will show that new statutory law on defamation has cast some doubt on this argument. Section 13 of the Defamation Act 1996 has created a considerable surplus of procedural options for MPs as opposed to non-members in defamation suits by introducing the possibility of a personal waiver of parliamentary privilege. This advantage must be held to exist solely for the benefit of individual members, since Parliament neither has a considerable benefit in it, nor a say in the application of section 13. The court mentioned section 13 as relevant law but it did not treat this point in its judgment. The third argument which the Court considered seems relatively shallow: it seems unreasonable to equate the possibility to petition the parliamentarian who is immediately concerned with a true possibility of legal recourse, while no legal consequences whatsoever are necessarily attached to such a petition and neither to a petition addressed to the Speaker or to the relevant House as a whole. The point made by the Court that, in extreme cases, Parliament could punish an MP for contempt does not alter the fact that a petition to the grace of Parliament by no means amounts to a (legal) 'means of redres'.

What remains, therefore, as the only really compelling argument - sustained by a variety of signatory state parties to the Convention, is that absolute freedom of speech (non-accountability), where it is limited to necessary areas, is in the general interest of democracy and thus constitutes a legitimate limitation of the right of access to court ex Article 6 ECHR. Consequently, the Court found no violation of Article 6 in A. v. UK. Still, the approval by the Court of blanket non-accountability appears rigid or, as Kloth puts it, 'overcautious' 17 in accepting the necessity of nonaccountability so readily: while it is true that non-accountability is ubiquitous in Europe, it is not entirely absolute in all contracting states. For instance, Article 46(1) of the German Constitution provides that it does not apply to 'defamatory insults'. ${ }^{18}$ Also, the Court did not explain in how far the existence of a more formal way of redress for victims of abuse in parliament would in fact interfere with the legitimate aim of protecting parliament from undue external influence. Even if access to court is undesirable, as it is the object of non-accountability to keep the judiciary out of the exclusive sphere of the legislature, it might not be irreconcilable with the necessary protection of parliament if petitions for redress would at least not be left entirely at the mercy of individual MPs or the Speaker (as is the case under British law), but at that of a committee. It appears that this would breathe some life into the Court's third argument - that victims of a defamatory statement by a parliamentary

Kloth 2010, p. 190.

18 German: verleumderische Beleidigungen. 
figure are not left entirely without redress since they may still petition their MP without hampering Parliament's protection to more than an acceptable degree.

In $A v$. the $U K$, an interesting argument against absolute freedom of speech in parliament was put forward in the dissenting opinion of Judge Loucaides, the only judge who voted in favour of finding a violation of Article 6. He argued that

' $[\mathrm{t}]$ he suppression of untrue defamatory statements, apart from protecting the dignity of individuals, discourages false speech and improves the overall quality of public debate through a chilling effect on irresponsible parliamentarians' ${ }^{19}$

He thus finds that absolute freedom of speech constitutes a disproportionate limitation of Article 6 of the Convention. At first sight, this argument appears tempting. However, it is clear that Judge Loucaides' approach must be treated with care, since it aims at the very heart of parliamentary non-accountability as an emanation of the constitutional principle of separation of powers: according to this principle, it should not be for the courts to determine how a responsible parliamentarian should behave, or to secure the quality of public debate.

With regard to absolute non-accountability for utterances in parliament, $A v$. the United Kingdom has so far not been overruled; it has been confirmed in the similar case of Zollmann $v$. the United Kingdom. ${ }^{20}$ However, in a series of cases against Italy, the Court in Strasbourg developed a more differentiated approach to nonaccountability regarding statements made by parliamentarians outside parliament. The first of these cases was Cordova v. Italy (No. 1). ${ }^{21}$ The Court first outlined the Italian system of non-accountability, 22 based on Article $68(1)$ of the Italian Constitution, which reads as follows: 'Members of Parliament shall not be required to account for the opinions they express
or the votes they cast in the exercise of their functions'. [Emphasis added]

The Legge Costituzionale No. 3 of 1993 has abolished the need to obtain leave from the relevant chamber of parliament to initiate proceedings against a member of parliament. However, the chambers of the Italian legislature may decide (by a resolution, usually at the request of the parliamentarian concerned) whether particular statements made by parliamentarians fall within the scope of this provision. Such resolutions may not be quashed by the ordinary courts, but the Italian Constitutional Court may review whether the parliamentary chamber in question has acted within its constitutional competence in adopting it.

Traditionally, the chambers have given a broad interpretation to Article 68(1) of the Constitution. They take this provision to apply even to statements made outside parliament which are not connected to parliamentary activity as such, because they constitute 'an outward projection of parliamentary activity and come

A v. the United Kingdom, dissenting Opinion of Judge Loucaides.

Zollmann v. the United Kingdom, ECHR 27 November 2003, App. No. 62902/00.

Cordova v. Italy (No. 1), ECHR 30 January 2003, App. No. 40877/98.

Ibid., paras. 22-28. 
within the mandate given by the voters to their elected representative'.$^{23}$ The Italian Constitutional Court has adopted a much narrower view, arguing that extending the scope of Article 68(1) to all political activities of a member, whether or not related to their parliamentary work, would convert parliamentary immunity into a personal privilege. ${ }^{24}$ According to established case law of the Constitutional Court, statements made by a parliamentarian outside parliament must at least relate to prior parliamentary activity in order to fall within the scope of non-accountability. ${ }^{25}$

The Cordova case before the European Court of Human Rights concerned a dispute between a public prosecutor and the former President of the Italian Republic, Francesco Cossiga, who had become Senator for life after the end of his presidential term. The applicant had investigated a person who had certain dealings with Mr Cossiga. Thereupon, Mr Cossiga sent the applicant letters in which he 'said he was making him a gift of the copyright in his written, telephone and oral communications' with the person under investigation, 'including for the purposes of their stage and film exploitation'. Next to this, Mr Cossiga also sent the prosecutor a wooden horse and a tricycle, together with a note that said 'Have fun, dear Prosecutor'. ${ }^{26}$

The applicant filed a complaint against Mr Cossiga, whereupon proceedings were brought against the former President for the insultation of a public official. However, the Senate adopted a resolution in which it held that the letters and parcel sent to the applicant fell within the scope of Article 68(1) of the Constitution and that Mr Cossiga thus benefitted from parliamentary non-accountability. The district court, after having found that the resolution of the Senate was lawfully adopted and not manifestly unreasonable, held that it lacked jurisdiction to question the decision of the Senate any further. The applicant was also refused leave to appeal against the district court's ruling and thus to bring the matter before the Constitutional Court as a conflict of state powers. He therefore complained to the European Court of Human Rights, alleging a violation of his right of access to court.

Before addressing the question whether parliamentary immunity (in this case, non-accountability) constituted a disproportionate limitation of the applicant's rights under Article 6 of the Convention, the Court first had to determine whether the applicant had in fact been denied access to court - after all, the district court had examined the prima facie lawfulness of the Senate's resolution and had come to the conclusion that it was lawful and not manifestly unreasonable. However, the ECtHR held that:

Ibid., para. 25

Corte Costituzionale, judgment No. 289 of 18 July 1998.

Cordova v. Italy (No. 1), para. 27, citing judgments Nos. 10, 11, 56, 58 and 82 of 2000; Nos. 137 and 289 of 2001 and Nos. 50, 51, 52, 79 and 207 of 2002 of the Corte Costituzionale. Ibid., para. 11. 
such an examination cannot be equated with a decision on the applicant's right to the protection of his reputation, nor can a degree of access to a court limited to the right to ask a preliminary question be considered sufficient to secure the applicant's 'right to a court', having regard to the rule of law in democratic society. [...] In this connection, it should be borne in mind that, in order for the right of access to be effective, an individual must have a clear and practical opportunity to challenge an act interfering with his rights. ${ }^{27}$

Addressing the principal question whether non-accountability constituted a proportionate limitation of the right of access to court, the Court gave a dismissive answer:

\begin{abstract}
Although [...] Mr Cossiga had criticised the applicant's investigations in an earlier parliamentary question, the Court considers that ironic or derisive letters accompanied by toys personally addressed to a prosecutor cannot, by their very nature, be construed as falling within the scope of parliamentary functions. [...]

The Court takes the view that the lack of any clear connection with a parliamentary activity requires it to adopt a narrow interpretation of the concept of proportionality between the aim sought to be achieved and the means employed. This is particularly so where the restrictions on the right of access stem from the resolution of a political body. ${ }^{28}$
\end{abstract}

Accordingly, the European Court of Human Rights found a violation of Article 6(1) of the Convention and awarded the applicant non-pecuniary damages. It upheld the above line of reasoning in Cordova $v$. Italy (No. 2), ${ }^{29}$ in which another parliamentarian had insulted the same applicant in two speeches he had given at election meetings, and in three cases in which the applicants had been denied access to court in defamation proceedings against Italian parliamentarians who had made defamatory statements in press interviews. ${ }^{30}$

Reading the case law in A, Zollmann, Cordova and the other Italian cases in conjunction reveals a consistent pattern in the Court's approach to nonaccountability. On the one hand, it recognises the absolute freedom of parliamentary debates as a constitutional tradition present in all contracting states and accepts it as a legitimate and proportionate limitation of the rights ex Article 6 of the Convention. However, where the statements concerned have not been made in parliament, the Court requires a very narrow and material connection to the parliamentary work of the member in question in order for non-accountability to be proportionate. The fact that the member has referred to the applicant in parliament before making the statements concerned outside parliament is insufficient. Also, as seen in Cordova (No. 1), the Court takes the view that certain acts of expression are

Ibid., para. 52

Ibid., paras. 62-63.

Cordova v. Italy (No. 2), ECHR 30 January 2003, App. No. 45649/99.

De Jorio v. Italy, ECHR 3 June 2004, App. No. 73936/01; Ielo v. Italy, ECHR 15 March 2005, App. No. 23053/02; Patrono, Cascini and Stefanelli v. Italy, ECHR 20 April 2006, App. No. $10180 / 04$. 
'by their very nature' incapable of being connected with the parliamentary functions of a member.

\subsubsection{Inviolability under Article 6 ECHR}

With regard to inviolability - the immunity of members of parliament from legal action for acts committed outside parliament - the ECtHR has adopted an approach very similar to that which it has taken towards non-accountability. In all but one case (Kart $v$. Turkey, see below) it has not even explicitly recognised a formal difference between the two forms of immunity. However, we will see in the following that the approach of the Court leads to different effects in cases involving non-accountability and inviolability, respectively.

Also in systems where, unlike in Italy, non-accountability does not extend beyond the spatial and temporal confines of parliamentary debates proper, extraparliamentary utterances may still be protected by inviolability. As opposed to nonaccountability, inviolability is usually temporally limited to the duration of the parliamentary mandate. It can also normally be lifted, usually by the chamber of parliament to which the member concerned belongs. The degree to which parliamentarians are inviolable differs considerably - mostly, they may not be detained without the prior authorisation of parliament (except flagrante delicto). Often, also investigative measures like searches or wiretapping are prohibited, while some states even prohibit the criminal prosecution of members of parliament in general (France did so prior to the constitutional amendment of 1995). In order for inviolability to apply, most systems do not require that the alleged criminal act holds any connection with the parliamentary functions of the member. ${ }^{31}$

Despite the temporary nature of inviolability, the ECtHR has been critical of this form of immunity. Even though case law with regard to inviolability is relatively scarce, it is recognisable that the Court is reluctant to accept a limitation of the right of access to court in cases where the object of legal proceedings against the parliamentarian concerned is not, or is insufficiently, connected with his parliamentary functions. In the case Tsalkitzis $v$. Greece, ${ }^{32}$ a construction developer wished to bring corruption charges against a member of parliament. The latter had previously been the mayor of Kifissia, a suburb of Athens. In this capacity, in 1997, he had allegedly caused the building permit for one of the applicant's projects to be revoked and construction works to be halted. According to the applicant, the mayor had then demanded a substantial bribe for allowing construction works to resume. The applicant had refused to pay and instead successfully challenged the decision to revoke the building permit in court. In November 2001, the applicant finally filed a complaint of blackmail and abuse of office and joined the action as a civil party, claiming damages. Meanwhile, however, the former mayor had been elected to parliament in the general elections of 2000 and was now protected by inviolability. The trial court requested parliament to lift the inviolability of the member in 
question but the request was denied in March 2002. After the ECtHR had given its ruling in Cordova in early 2003, the applicant filed a new criminal complaint against the former mayor, arguing that the Cordova judgment constituted a novel fact which merited a re-examination of the case by parliament. The procurator general at the Greek Court of Cassation, to whom the case had been transmitted in conformity with the Rules of Procedure of parliament, agreed with the applicant and requested parliament to reconsider the lifting request. Again, the request was denied.

In assessing whether parliamentary immunity, in the particular circumstances of the case, constituted a proportionate limitation of the applicant's rights ex Article 6 of the Convention, the ECtHR first observed that the alleged criminal act had taken place almost three years prior to the former mayor's election to parliament. Moreover, the Court noted that a connection between the alleged crime of blackmail and corruption with the former mayor's parliamentary functions could not be assumed, since it fell well outside the sphere of normal (read: acceptable) parliamentary business and since it was of a particular immoral nature. The Court then reiterated what it had held in Cordova: that, lacking a clear connection with the parliamentary functions of the member concerned, a narrow interpretation of proportionality had to be employed, especially where the restriction of access to court followed from the decision of a political body. Finally, the Court addressed the argument of the Greek government that the limitation of access to court by virtue of inviolability was nonetheless proportionate because it was only temporary and would cease with the end of the mandate. The Court dismissed this argument, considering that Greek parliamentarians could be re-elected indefinitely. If the member in question were to remain a member of parliament for a long time, this could create a time lapse which would potentially make it difficult to prove the alleged crimes. ${ }^{33}$

It follows from Tsalkitzis that the Court applies the same main criterion in its assessment of non-accountability and inviolability - the alleged act needs to be connected to the parliamentary functions of the member concerned in order for the limitation of access to court to be justified. This cannot be the case where the alleged crime was committed before the beginning of the mandate. In addition, the temporary nature of inviolability does not make the limitation proportionate, at least not where the mandate is renewable indefinitely.

In the light of the Italian cases referred to earlier, the Court's ruling in Tsalkitzis is unsurprising. It is still remarkable, since it calls into question the very concept of inviolability, which, after all, explicitly intends to protect parliamentarians of legal action relating to activities of members outside their parliamentary mandate. This serves the purpose of preventing politically motivated lawsuits against members and to safeguard their unimpeded attendance of parliament. Certainly, both of these aims were not at stake in this case, since the alleged crime was manifestly unrelated to any political activity, and as detention was not at issue. Nevertheless it is evident that the generous inviolability enjoyed by Greek parliamentarians - it prohibits not only arrests but criminal prosecution in general - can virtually never pass the 
Court's proportionality test unless either the alleged criminal act is manifestly connected with parliamentary activities or unless the prosecution is politically motivated.

This was confirmed more recently in Syngelidis v. Greece. ${ }^{34}$ The applicant in this case was the ex-husband of M.A. At the material time, M.A. was a member of the Greek parliament. After the end of their marriage, the two had concluded an agreement with regard to custody of their son. This agreement, endorsed by a court, granted the applicant free access and regular contact with his child. However, on a number of occasions the applicant had allegedly been denied contact with the child. M.A. had also brought criminal proceedings against the applicant for placing a security guard outside her house. These proceedings had been heard in court and dismissed in the first instance and appeal courts. Later, the applicant himself had brought criminal proceedings against his former spouse for denying him contact with his son and joined these proceedings as a civil party, claiming the symbolic sum of ten euros in damages. A request to lift M.A.'s inviolability had been made to parliament, and was considered by a committee which had assessed whether one of the grounds for denying the request was present. According to the Rules of Procedure of the Greek parliament, these reasons are (a) that the alleged criminal offence relates to the parliamentary activities of the member, (b) that the prosecution is politically motivated, or (c) that it undermines the authority of parliament or of the MP or obstructs the exercise of their functions. The committee had simply advised that one of these reasons applied, but had not specified which one. Subsequently, parliament had decided to uphold M.A.'s inviolability, to the effect that the criminal case against her could not be heard in court. A later request to lift immunity, on the occasion of new charges brought by the applicant, had been denied on the ground that it was essentially the same as the first request.

After the ECtHR declared the application admissible, it was confronted with important structural arguments submitted by both the applicant and the Greek government. On the one hand, the government argued that the limitation which inviolability presented for the right of access to court was proportionate, because the Greek inviolability regime prohibited criminal proceedings against members of parliament, not civil proceedings. Hence, instead of joining criminal proceedings with a merely symbolic claim in damages, the applicant could have lodged a proper civil claim against M.A., which could have resulted in a substantial sum of damages that constituted an adequate remedy. The applicant, on the other hand, conceded that inviolability was in principle capable of being compatible with Article 6(1) $\mathrm{ECHR}$, but only if the Greek parliament, in exercising its discretionary power to lift inviolability, interpreted and applied the relevant constitutional provisions correctly, which it had not done in this case and in many others. According to a survey submitted by the applicant, between 1974 and 2003 the Greek parliament had granted a mere five out of 800 requests to lift inviolability, thus systematically shielding its members from criminal proceedings. In the light of this practice, the circumstances of the present case and the Court's rulings in Cordova and Tsalkitzis, 
the applicant was of the opinion that his right of access to court had been breached. Moreover, the applicant argued that inviolability created a disproportionate imbalance between himself and his ex-wife, as she had remained free to bring criminal proceedings against him, but not vice versa. ${ }^{35}$

The Court dismissed the government's argument that the possibility of civil proceedings against M.A., of which the applicant had made no use, were sufficient to offset or render proportionate the limitation of Article 6 ECHR with regard to criminal proceedings. According to the Court,

where the domestic legal order provides an individual with a remedy, such as a criminal complaint with the possibility to join the proceedings as a civil party, the state has the duty to ensure that the person using it enjoys the fundamental guarantees of Article $6 .{ }^{36}$

With regard to the arguments brought forward by the applicant, the Court reiterated the principles it had developed in Cordova and subsequent case law: that parliamentary immunity was in principle compatible with the ECHR where it served the legitimate aim of protecting parliament from undue influence, but that proportionality had to be given a narrow interpretation where there was no clear connection between the alleged criminal behaviour of the member and his parliamentary functions. This was clearly the case here, since M.A.'s behaviour was entirely unrelated to her parliamentary work and 'more consistent with a personal quarrel' ${ }^{37}$ Accordingly, the Court noted that the parliamentary committee which examined the lifting request had stated no particular reason for the decision not to lift inviolability, thus denying the applicant even the possibility to know why, specifically, he was barred from access to court. Finally, the Court 'attache[d] some significance to the fact that the impugned approach of the Parliament has created an imbalance in treatment between the applicant and M.A., since the latter was able to bring proceedings against the applicant $[\ldots]^{\prime} .^{38}$ The Court therefore held that the applicant's right ex Article 6(1) ECHR had been violated.

With Syngelidis $v$. Greece, the Court in Strasbourg has consolidated its functional approach to parliamentary immunity: it is legitimate in principle for contracting states to protect their legislatures by means of an immunity system which ensures that parliaments can discharge their constitutional functions free from any undue influence. Implicitly, it recognises parliamentary debate - that is to say, debate in parliament - as the most essential function of a legislative body. Accordingly, the protection of this function by means of an absolute immunity is proportionate, as was established in $A v$. UK. But the further an act of a member is removed from this core function, the narrower the concept of proportionality must be interpreted. It follows that, where an alleged criminal act of a member is entirely unrelated to his parliamentary work, this act must in principle not be protected by

Ibid., paras. 37-39.

Ibid., para. 45

Ibid., para. 46

Ibid., para. 48 
immunity, unless there are good reasons for such protection in addition to the mere fact that the defendant is a parliamentarian. For instance, the Court's judgment in Syngelidis does not rule out that the Court would have accepted M.A.'s inviolability despite the private nature of her alleged criminal behaviour, if parliament had credibly argued that her prosecution was politically motivated.

Kart v. Turkey ${ }^{39}$ was the only case to date in which a parliamentarian, thus the beneficiary of parliamentary immunity himself, complained that his rights under Article 6 of the Convention had been violated as a result of immunity. Before he was elected a deputy of the Turkish Grand National Assembly, the applicant in this case had worked as a lawyer. In this capacity, criminal charges had been brought against him for insulting another lawyer and a public official. However, after his election, proceedings were stayed in accordance with Turkish inviolability rules. In order to be able to defend his reputation in court, the applicant requested his inviolability to be lifted, but the request was denied by the competent committee of the Grand National Assembly. The applicant appealed the committee's decision, arguing among others that the aim of inviolability was not to render members of parliament unaccountable but only to secure the independent and dispassionate discharge of their functions. In the view of the applicant, 'the scope of the immunity, the procedure for lifting it and the shortcomings in its implementation had undermined due respect for the National Assembly'. He also contended that it was 'unacceptable, in a society governed by the rule of law, that an institution originally meant to help MPs to discharge their duties should be transformed into a personal privilege'.40 Nevertheless, his request was denied again. The applicant then unsuccessfully challenged the committee's decision before the plenary assembly. After the end of his first term as a deputy, the applicant was re-elected but had still not managed to have his inviolability lifted.

As mentioned earlier, the Court's judgment in Kart was the first one in which it acknowledged that parliamentary immunity usually consists of two component parts, non-accountability and inviolability, that the two pursue different aims and are of a different legal nature, and that the applicant only challenged the application of inviolability. Before assessing the case on the merits, the Court gave a comparative account of the immunity systems of the contracting states, the Parliamentary Assembly of the Council of Europe and the European Parliament, in which it found that most states do provide for an extra-professional immunity (inviolability). The Court then '[made] it clear at the outset that its role is not to rule in an abstract manner on the compatibility of the system of parliamentary immunity with the Convention, but to ascertain in concreto whether [its] application in this case $[. .$.$] violated Article 6$ of the Convention' ${ }^{41}$ It went on to hold that inviolability, given its aim of securing the unimpeded functioning of parliament and its members, is in principle legitimate. The judges held, cautiously, that 
[although] the Court cannot be used as a means of verifying the relevance of the choices made by the national parliaments in the matter, it nonetheless remains that parliamentary practice must be in conformity with the imperatives of the rule of law as embodied in the Convention. ${ }^{42}$

Subsequently, the Court held that Turkish inviolability is unusually broad in that it applies to both criminal and civil proceedings and covers acts committed before the election of a member. It also observed that under Turkish law the decision whether or not inviolability is to be lifted need not - and in this case was not - substantiated by any argument, that there is no time limit for this decision and that inviolability, if upheld, inevitably leads to a long time lapse before a criminal trial can commence or be resumed. Finally, 'the Court [could not] ignore that parliamentary 'inviolability' in Turkey is a controversial subject and [...] has been identified as one of the main problem areas in the context of corruption' ${ }^{43}$ For these reasons, the judges found in favour of a violation of Article 6(1), even if by a narrow majority of four votes to three.

This judgment was, however, reversed by the Grand Chamber. ${ }^{44}$ This time, the majority (thirteen votes to three) based its decision on the argument that the charges against the applicant had been brought before his election, so that he was aware that, by becoming a parliamentarian, the determination of his criminal case was likely to be delayed. ${ }^{45}$ In addition, the Grand Chamber also found that the temporary nature of inviolability mitigated the limiting effect of inviolability on Article 6. It even went so far as to say that

not only is the obstruction to criminal procedure as a result of parliamentary inviolability only temporary, but in principle Parliament does not intervene at all in the course of justice as such [...] [since] it seems only to have considered whether inviolability, as a temporary obstacle to judicial action, should be lifted immediately or whether it was preferable to wait until the end of the applicant's term in Parliament. ${ }^{46}$

Both of these arguments appear doubtful and unsound. As Judge Power correctly observed in his dissenting Opinion, the first argument means that the applicant's choice to exercise one of his Convention Rights (the right to stand for parliament, protected under Article 3 of Protocol No. 1 to the Convention) had already implied a waiver of another, namely his right of access to court under Article $6 .{ }^{47}$ The second argument is not only inconsistent with the Court's own ruling in Tsalkitzis, it also does not hold much water with regard to the temporal aspect of Article 6 of the Convention, which not only guarantees access to court, but also a hearing within a reasonable time.$^{48}$ Finally, the statement that the decision not to lift inviolability was

Ibid., para. 84

Ibid., para. 92.

Kart v. Turkey (Grand Chamber), ECHR 3 December 2009, App. No. 8917/05.

Ibid., para. 106.

Ibid., para. 109.

See also Kloth 2010, p. 198.

This has also been observed in the dissenting Opinion of Judge Bronello and two others. 
essentially not about access to court can only be described as judicial pettifoggery and sits very oddly with the Court's earlier case law on inviolability. Kloth has noted that the Grand Chamber judgment also failed to take into account the interests of the victims of the applicant's alleged criminal behaviour. ${ }^{49}$

The arguments on which the Grand Chamber based its judgment in Kart appear laboured and cumbersome; they give a strong impression that the reasoning of the Grand Chamber was influenced by the desired result. As a consequence, the second judgment in Kart, which predated that in Syngelidis by little more than two months, stands out in the otherwise quite consistent case law of the European Court of Human Rights with regard to parliamentary immunity and Article 6 of the Convention.

\subsubsection{Article 6 ECHR and the Penal Powers of Parliament}

So far, we have dealt with the issue of access to court in the context of the possibility of filing lawsuits against members of parliament. Next to this, another scenario in which Article 6 ECHR is potentially at stake is the exercise of parliament's penal powers. This scenario is not immediately related to the concept of parliamentary immunity as defined in Chapter I, but it nevertheless falls within the scope of our study, because the power of jurisdiction which many parliaments enjoy over their own affairs - and sometimes slightly beyond - is closely intertwined with the idea of immunity.

Legal problems with regard to parliamentary penal powers are very unlikely to arise for parliaments in continental Europe because their jurisdiction is usually limited to the maintenance of order in the plenary hall. As our British case study will show, this is different in Westminster-type parliaments, where parliamentary privilege is largely based on the idea of parliament as a court of law (the High Court of Parliament). As a result, the penal powers of parliaments based on the British model can exceed those of continental parliaments and may extend beyond the mere regulation of parliamentary debates. The following is therefore mainly relevant to our case study of the United Kingdom. ${ }^{50}$

Westminster-type parliaments have the power to punish both members and non-members for contempt or breach of privilege. This may give rise to problems under Article 6(1) ECHR, which confers upon everyone the right to have criminal charges determined in a fair hearing by an independent tribunal. Where a parliament or parliamentary chamber chooses to exercise its penal powers, does the accusation of a breach of privilege or contempt of parliament constitute a 'criminal charge' within the meaning of Article 6(1) ECHR? If this is answered in the positive, does parliament constitute 'an independent and impartial tribunal established by law' as Article 6 ECHR requires? These questions were at issue in the case Demicoli

Kloth 2010, p. 197-198.

50 On a side note, the penal powers of parliament are therefore not only relevant to our discussion of parliamentary immunity and the ECHR, but they also provide us with very helpful entry points for a discussion of the peculiar nature of the law of parliament in the UK and of parliament in its capacity as a court with regard to that body of law. 
v. Malta. ${ }^{51}$ The penal powers of the Maltese parliament are laid down in statutory form. In particular, Maltese law provides definitions of contempt and breach of privilege, and of the penalties which parliament can impose. This clearly distinguishes Malta from the United Kingdom, where this is not the case. However, Malta's parliamentary privilege and law of contempt has its foundations in British law, which was acknowledged and considered by the Court in Demicoli. ${ }^{52}$ Therefore, certain inferences may be drawn from the case for the situation in the United Kingdom.

The applicant in Demicoli had written and published an article in which he referred to several members of parliament as 'clowns' and ridiculed statements they had made during a parliamentary debate. He was thereupon ordered to appear before the House of Representatives for a hearing on charges of contempt, allegedly committed by having written a defamatory libel. The House subsequently found the applicant guilty of contempt of parliament. Before it imposed a punishment on $\mathrm{Mr}$ Demicoli, he had instituted court proceedings, complaining of a violation of the Constitution by the House in denying him the constitutional right to a fair hearing by an independent court. The matter was taken up by the Constitutional Court, which decided that a procedure in the House for breach of privilege, though involving a charge which is also criminal in nature pursuant to Maltese law (defamatory libel is a crime under the Maltese criminal code) and despite the fact that the possible penalties to be imposed by the House are very similar to criminal punishments, the House could not be seen as a criminal court and a declaration of guilt of contempt did not therefore equate to a criminal sentence. ${ }^{53}$ However, the Constitutional Court required that the existence of a defamatory libel be established by a regular court of law before Parliament could impose a penalty for contempt. Later, the House imposed a pecuniary fine on the applicant.

The judges of the ECtHR, in consideration of the question whether breach of privilege constituted in itself a 'criminal charge', answered this question in the affirmative after applying a test of three criteria, consistently applied in ECtHR case law. These are, first, whether the national law in question categorises the offence as criminal, second, whether 'the very nature of the offence' in question is that of a criminal offence, and third, the degree of severity of the punishment which the concerned person could possibly incur. Under Maltese law, defamatory libel is a criminal offence, but contempt of parliament or breach of privilege is not. However, the Court held that 'the particular breach of privilege is akin to a criminal offence' and that the possible punishment (a fine or a prison sentence) was sufficiently severe, so that the House needed to be found to have engaged in criminal proceedings against the applicant.

As regards the question whether the House was an independent and impartial court established by law, satisfying the requirement of Article 6 ECHR, the Court gave a negative answer. It held that, pursuant to its case law, 
a 'tribunal' is characterised in the substantive sense of the term by its judicial function, that is to say determining matters within its competence on the basis of rules of law and after proceedings conducted in a prescribed manner ... It must also satisfy a series of further requirements - independence, in particular of the executive; impartiality; duration of its members' terms of office; guarantees afforded by its procedure - several of which appear in the text of Article 6 para. 1 (Art. 6-1) itself. ${ }^{54}$

Given that the two members of the House allegedly defamed by the applicant were participating in the hearing before the House as quasi-judges, the Court argued that the impartiality criterion of Article 6 was not fulfilled. Demicoli's right to a fair trial under Article 6 ECHR had accordingly been violated.

As stated above, this case could not have arisen in continental parliaments, but possibly in Westminster Parliament (even though this is highly unlikely, as the British Parliament has resolved to apply its penal powers with restraint). The judges of the ECtHR held in Demicoli that the penal powers of the House were not at issue in the proceedings before them, but rather the manner in which they were applied in Mr Demicoli's particular case. Nonetheless, the answers found by the ECtHR to the two questions of whether breach of privilege is (or can be) a criminal offence and whether Parliament constitutes an Article 6 'tribunal' are relevant to our examination of Westminster Parliament, in which we will assess the concept of parliament as a court. Breach of privilege is not a statutory criminal offence in the UK (and of course it cannot be one in common law: the point of parliamentary privilege is that common law does not apply to parliamentary affairs, as will be shown). However, according to the Strasbourg Court, certain particular breaches, among which are grave cases of defamatory libel against members of Parliament, 55 qualify as being 'akin' to criminal charges. In such a case one needs to determine whether the respective House of Parliament fulfils the criteria for being an independent and impartial tribunal. If the relevant House does not take certain procedural precautions, such as excluding the alleged victims of defamation from a hearing before the House and granting the defendant the right to legal counsel, the exercise of parliamentary penal powers may constitute an infringement of Article 6 ECHR.

\subsubsection{Parliamentary Immunity and Freedom of Expression: Article 10 ECHR}

Parliamentary immunity also raises issues under Article 10 of the Convention, which guarantees the right of freedom of expression. Article 10 reads as follows:

1. Everyone has the right to freedom of expression. This right shall include freedom to hold opinions and to receive and impart information and ideas without interference by public authority and regardless of frontiers. [...]

Ibid., para. 15

Ibid., para. 39

But only as regards matters involving these members in their capacity as members, i.e. where the defamation is connected, in some way to 'proceedings in parliament'. 
The European Dimension of Parliamentary Immunity

2. The exercise of these freedoms, since it carries with it duties and responsibilities, may be subject to such formalities, conditions, restrictions or penalties as are prescribed by law and are necessary in a democratic society, in the interests of national security, territorial integrity or public safety, for the prevention of disorder or crime, for the protection of health or morals, for the protection of the reputation or rights of others, for preventing the disclosure of information received in confidence, or for maintaining the authority and impartiality of the judiciary.

It should be noted that Article 10 is the only provision of the Convention which explicitly states that the exercise of the right contained in it 'carries with it duties and responsibilities', which is particularly relevant for elected representatives.

The relationship between our subject and the right to freedom of expression is indirect. Parliamentary immunity itself does not usually have the potential to infringe this right, ${ }^{56}$ but it is useful to determine the exact extent of freedom of expression in order to establish the limits of parliamentary immunity, by answering two questions. First, do members of parliament (when speaking outside parliament) generally enjoy a wider margin of freedom of expression than 'ordinary' citizens? If so, this could be interpreted as a special privileged status for parliamentarians under the ECHR - a form of immunity under the Convention. Second, are there special limitations on freedom of expression with regard to remarks about parliamentarians? If this question were answered in the positive, this would also confer an extra degree of protection on members of parliament. Both of these questions have been addressed by the European Court of Human Rights, though the body of case law is significantly smaller and much less conclusive than that of parliamentary immunity under Article 6 of the Convention.

\subsubsection{Freedom of Expression for Parliamentarians outside Parliament}

An important judgment of the European Court of Human Rights with regard to the freedom of expression of parliamentarians outside parliament was that in Castells $v$. Spain. ${ }^{57}$ At the material time, the applicant was a Senator for the Basque political group Herri Batasuna, ${ }^{58}$ and had heavily criticised the Spanish government in a magazine article (and not in the Senate, where he would have enjoyed nonaccountability). In his article, he had lamented that numerous violent crimes allegedly committed by well-organised fascist groups had gone unpunished while hundreds of members of ETA had been imprisoned, and thousands arrested over the criminal activities of the Basque secessionist group. The applicant suggested that the crimes committed by right-wing groups must have had the backing of the Spanish government. He was subsequently charged with insulting the government, a crime punishable under Spanish law by a substantial prison sentence or a fine. On

56 An exception might be the law of contempt in Westminster-type systems, where parliament can avail itself of its penal powers and sanction individuals who have committed a contempt or breach of privilege by their utterances. This may constitute an infringement of these individuals' convention rights; see Demicoli $v$. Malta, discussed in the previous section.

57 Castells v. Spain, ECHR 23 April 1992, App. No. 11798/85.

58 The organisation was prohibited in 2003. 
trial, the applicant offered to substantiate the truth of his alleged insults, but the Supreme Court, which conducted his trial, ruled that a defence of truth was not admissible in proceedings for slurs against the government, since the truth of a statement was immaterial for its insulting character. The Supreme Court finally sentenced the applicant to one year and a day in prison. He was also disqualified from public office for the same amount of time, but the execution of both penalties was stayed pending the decision of the Constitutional Court, to which the applicant had appealed. Two years later, the Constitutional Court dismissed the appeal but ruled that the prison sentence had already been served.

The applicant complained of a violation of his right to freedom of expression under Article 10 of the Convention. Since Mr Castells was a member of the Spanish Senate at the time, the Court not only had to determine whether his conviction had violated Article 10, but also whether, as an elected representative, he enjoyed a wider freedom of expression than others. First, the Court held in Castells that, in general, freedom of expression does not only pertain to ideas which are favourably received but also to opinions which 'offend, shock or disturb' ${ }^{59}$ Crucially for our purpose of determining that question, the Court remarked that

[w]hile freedom of expression is important for everybody, it is especially so for an elected representative of the people. He represents his electorate, draws the attention to their preoccupations and defends their interests. Accordingly, interferences with the freedom of expression of an opposition member of parliament, like the applicant, call for the closest scrutiny on the part of the Court. ${ }^{60}$

But what does this mean? That limitations of the freedom of expression of representatives have to be subject to 'the closest scrutiny' does not say that such limitations are per se less permissible in the case of a parliamentarian, than in other cases. On the other hand, it certainly does say that they must be treated with the utmost care. However, the Court went on to hold that

\footnotetext{
[t] he freedom of political debate is undoubtedly not absolute in nature. A Contracting State may make it subject to certain 'restrictions' or 'penalties', but it is for the Court to give a final ruling on the compatibility of such measures with the freedom of expression enshrined in Article 10. [...]

The limits of permissible criticism are wider with regard to the government than in relation to a private citizen, or even a politician. In a democratic system, the actions or omissions of the Government must be subject to the close scrutiny not only of the legislative and judicial authority but also of the press and public opinion. ${ }^{61}$
}

Based on this finding, and on the fact that the applicant had been denied the opportunity to prove the truth of his allegations against the Spanish government, the Court found a violation of Article 10.

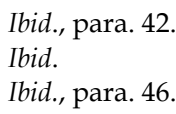


Can we therefore conclude that parliamentarians enjoy a wider freedom of expression than other citizens? It is not certain. More recent ECtHR case law suggests that the determining factor for the Court is not so much the status of an individual as a parliamentarian or other representative of the people, but the relevance of the remark in question for public political debate. In Keller v. Hungary, ${ }^{62}$ the applicant, a parliamentarian, had made derogatory statements about the late father of a minister. The latter successfully sued the applicant for damages, arguing that the parliamentarian had harmed his reputation. The ECtHR found the applicant's complaint under Article 10 of the Convention manifestly ill-founded. Apparently, the Court finds non-political statements, even if they come from parliamentarians, less worthy of protection than genuine political statements. However, in the case of Öllinger v. Austria, ${ }^{63}$ a member of parliament had made certain statements which could not be proven but which, as the ECtHR explicitly acknowledged, were important for societal debate. Nevertheless, in this case the Court in Strasbourg held that the limitation of the member's freedom of expression by the Austrian court was not disproportionate, and thus justifiable.

In 2009, the Strasbourg Court delivered its judgment in the case of Féret $v$. Belgium. ${ }^{64}$ The applicant, Mr Féret, was the head of the extreme-right political party Front National and a member of the Belgian Chamber of Representatives. He was also the editor-in-chief of his party's publications and the owner of its website. As editor-in-chief, he had published and supervised the publication of a number of leaflets and other campaign publications which advocated anti-immigrant policies and whose content and tone was generally xenophobic and discriminatory. These publications led to numerous complaints and, finally, to criminal proceedings against Mr Féret for hate speech and incitement to discrimination. After his parliamentary immunity had been lifted and two appeals concerning the jurisdiction of the trial court had been dismissed, he was elected to the Brussels Regional Council and the Parliament of the French Community, both affording him new immunity. Nevertheless, he was finally tried by the Brussels Court of Appeal and sentenced to 250 hours of community service in the field of the integration of foreigners and a suspended prison sentence. In addition, he was declared ineligible for a period of 10 years.

The ECtHR, faced with the question whether the conviction of the applicant constituted a violation of his rights under Article 10 of the Convention, first reiterated principles that had already been cited in Castells: freedom of expression does not solely cover ideas which are considered inoffensive, but also opinions which offend, shock or disturb. Moreover, Article 10(2) of the Convention leaves little room for restrictions on freedom of expression in the domain of political discourse or questions of general interest. ${ }^{65}$ However, with reference to earlier case law, the judges also reiterated that the fight against racial discrimination in all its

Keller v. Hungary, ECHR 4 April 2006, App. No. 33352/02.

Öllinger v. Austria, ECHR 13 May 2004, App. No. 74245/01

Féret v. Belgium, ECHR 16 July 2009, App. No. 15615/07.

Ibid., para. 63 
forms and manifestations is of the utmost importance. ${ }^{66}$ Finally, the Court addressed the question whether parliamentarians enjoy a greater degree of freedom of expression than others:

\begin{abstract}
La qualité de parlementaire du requérant ne saurait être considérée comme une circonstance atténuant sa responsabilité. A cet égard, la Cour rappelle qu'il est d'une importance cruciale que les hommes politiques, dans leurs discours publics, évitent de diffuser des propos susceptibles de l'intolérance [...]. Elle estime que les politiciens devraient être particulièrement attentifs, en termes de défense de la démocratie et de ses principes, car leur objectif ultime est la prise même du pouvoir. [...] La Cour estime que l'incitation à l'exclusion des étrangers constitue une atteinte fondamentale aux droits des personnes et devrait par conséquent justifier des précautions particulières de tous, y compris des hommes politiques. ${ }^{67}$
\end{abstract}

This adds another interesting facet to the Court's approach to the question of freedom of expression of members of parliament. The quality of being a parliamentarian does not attenuate a person's responsibility - id est, provide him with a wider freedom of expression - but even leads to a greater duty of care. Politicians (thus also parliamentarians) must be 'particularly attentive in terms of the defence of democracy and its principles', since their aim is to come into power. Incitement to the exclusion of foreigners constitutes a 'fundamental attack on the rights of persons', so it justifies 'particular precautions', including against politicians. Consequently, the Court held that the limitation of the applicant's freedom of expression by the Belgian court had not violated the Convention. It follows from Féret, therefore, that hate speech and incitement to discrimination, even by campaigning politicians, is not protected by Article 10 of the Convention.

\title{
2.2.2.2. Freedom of Expression: Speaking about Parliamentarians
}

The second facet of freedom of expression which - though somewhat more remotely - relates to parliamentary immunity is the question to what extent a person's status of being a member of parliament limits the freedom of others to disseminate information about this person. This question has been at issue in the case of Karhuvaara and Iltalehti $v$. Finland. ${ }^{68}$ The newspaper Iltalehti had reported about a case of assault against a police officer. The headline of the relevant article had mentioned that the perpetrator was the husband of a member of the Finnish parliament. Under Finnish criminal law, dissemination of information about a person's private life is punishable if it is likely to cause that person damage or suffering, unless the information in question relates to the person's position in politics, business or public office and affects the evaluation of his activities in this position. At the material time, a provision in the Finnish Parliament Act (which was later repealed by a constitutional amendment in 2000) provided that, where the

66 Ibid., para. 71, with reference to Jersild v. Denmark, ECHR 23 September 1994, App. No. $15890 / 89$

$67 \quad$ Ibid., para. 75

68 Karhuvaara and Iltalehti v. Finland, ECHR 16 November 2004, App. No. 53678/00. 
victim of abuse was a member of parliament, this constituted a seriously aggravating circumstance. As the newspaper headline had only mentioned the parliamentarian to 'colour' the reported events, but who otherwise had nothing to do with her husband's criminal act, the newspaper and its editor-in-chief, $\mathrm{Mr}$ Karhuvaara, were convicted on the basis of the criminal provision mentioned above. They incurred heavy fines, aggravated, as was mandatory under the Parliament Act, by the victim's status as a member of parliament.

The applicants complained to the European Court of Human Rights that their conviction, and in particular the aggravation of their penalty by the victim's status as a parliamentarian, had violated their freedom of expression. Due to the agreement by all parties that the applicants' conviction amounted to a limitation of their rights ex Article 10(1) of the Convention and that it was prescribed by law, the Court only had to assess whether this limitation was 'necessary in a democratic society'. The Court was of the opinion that it was not. Together with the observation that even the national court had found the provision of the Parliament Act outdated, it based its decision on an assessment of the 'immunity effect' of that provision. Once again, the Court's functional approach can clearly be seen:

\footnotetext{
The present case does not raise the issue of parliamentary immunity directly as there was no question of Mrs A.'s immunity from civil or criminal action. Parliamentary immunity was, however, of indirect relevance as it was Mrs A.'s status as a member of parliament that led to more severe convictions and sentences under section 15 of the Parliament Act. This indirect protection afforded to parliamentarians by way of punitive and deterrent criminal sentences, directed towards third parties, is relevant both to the justification and the proportionality of the convictions.
}

\begin{abstract}
The Court notes that the offences in question did not have any connection with the performance of Mrs A.'s official duties as a member of parliament. No criticism of Mrs A. was suggested, and it has not even been claimed that the publication of Mrs A.'s name and picture in connection with the account of the criminal proceedings against Mr A. in any way affected Mrs A.'s freedom of speech or was capable of limiting free parliamentary debate. In the absence of any link with the aims underlying parliamentary immunity, the use of Mrs A.'s parliamentary status as an aggravating factor of the offences in question is problematic. ${ }^{69}$
\end{abstract}

Similarly to its approach to parliamentary immunity in cases relating to the right of access to court, the Court was not ready to accept a greater degree of protection for parliamentarians than was necessary in the light of their parliamentary functions. It may perhaps be concluded from the assessment of the Court (quoted above) that this approach is relevant not only for issues of freedom of expression, but to all (hypothetical) cases in which a person's status as a parliamentarian negatively affects the legal position of a third party. 


\subsection{ECtHR Case Law on Parliamentary Immunity: Conclusions}

Since $A$ v. the United Kingdom the European Court of Human Rights has created a body of case law from which some inferences can be drawn with regard to the Court's approach to parliamentary immunity and, hence, to the status of immunity under the ECHR. The Court's approach is very clearly a functional one: it accepts that parliamentary immunity is a constitutional norm present in all contracting states. This means that although the implementation of parliamentary immunity in practice differs considerably between the contracting parties, it must summarily be understood as a constitutional principle from which they did not mean to derogate by adopting the Convention. However, since parliamentary immunity necessarily conflicts with the right of access to court ex Article 6(1) of the Convention, the Court treats it as a limitation thereof, which must be assessed according to the well-known criteria of legitimate aims and proportionality.

It is generally accepted - including by the Court in Strasbourg - that parliamentary immunity aims at protecting the freedom of parliamentary debate and shielding parliament from undue influence. In short, parliamentary immunity serves to ensure that parliament can freely discharge its constitutional tasks. It is at this point that the Court applies a functional criterion: while the legal institution of immunity generally serves a legitimate aim, its application is only proportionate to this aim where it actually relates to the functions of parliament - or, since the immediate beneficiary of immunity is the individual parliamentarian, to the parliamentary functions of the member. The effect of parliamentary immunity is to bar judicial action against a parliamentarian, usually criminal or civil proceedings for certain acts or utterances. In the Court's view, where an act or statement has occurred as part of the core functions of parliament (for instance, a vote or speech in parliament), this merits absolute protection, as in $A v$. UK. While the Court has never contested explicitly that acts or utterances outside actual parliamentary debates can also fall within the parliamentary functions of a member, its 'proportionality threshold' becomes higher the further the act or utterance in question is removed from the core of parliamentary activity. Hence, statements made in newspaper interviews are not necessarily protected, insulting letters and gifts to a public prosecutor are by default irreconcilable with parliamentary activity.

Except in Kart v. Turkey, the European Court of Human Rights has never formally distinguished between non-accountability and inviolability but generally refers to 'parliamentary immunity' instead. Nevertheless it is clear that its functional approach bears different consequences for the two forms of immunity because of their very nature: non-accountability explicitly relates only to acts and utterances which are part of, or are very closely connected to, a member's parliamentary functions. Under its functional approach, the Court will therefore see non-accountability as a disproportionate limitation of Article 6 ECHR only where it actually denies this connection, as it did in Cordova and the other Italian cases.

Inviolability, on the other hand, relates by definition to acts of parliamentarians which lie in the extra-parliamentary sphere (as acknowledged by the Court in Kart). Therefore, despite the Court's repeated statement that 'some 
restrictions on access to court must be regarded as inherent [in Article 6(1) ECHR], an example being those generally accepted by the Contracting States as part of the doctrine of parliamentary immunity', ${ }^{70}$ we may conclude that the Court has in reality adopted a reverse approach to inviolability: in principle it constitutes a disproportionate limitation of the right of access to court. The Court will therefore find a violation of that right wherever the application of inviolability is not justified by additional reasons (such as a manifest relation between the alleged criminal act and parliamentary activities or a political motivation for criminal charges). Admittedly, case law is still too scarce and the cases insufficiently diverse to be absolutely certain about the consistency of the Court's rejection of inviolability in principle. The Grand Chamber judgment in Kart is a point in case against it. Nevertheless, cases like Tsalkitzis and Syngelidis clearly support our conclusion of a 'reverse approach'.

This is a highly interesting finding because it questions the legitimacy of an important part of the immunity systems of many European states vis-à-vis the ECHR. In most states parliament or a parliamentary body has a discretionary power to lift inviolability without the possibility to appeal this decision in court, so the narrow functional approach of the European Court towards inviolability has created a certain judicial inroad into the constitutional powers of parliament in many of the contracting states. It surely has done away with the idea (if it ever existed) of parliamentary immunity as a personal privilege for parliamentarians.

Finally, the European Court of Human Rights has also had occasion to pronounce on the penal powers of parliament in relation to Article 6 of the Convention. It has done so in only one judgment (Demicoli v. Malta) which must be deemed to be of relevance only to the power of Westminster-type parliaments to punish for contempt and breach of privilege. Nevertheless, one may conclude from Demicoli that the ancient view of parliament as a court of law - on which we will elaborate in the course of our case study of the UK - is likely to conflict with the requirements of the ECHR.

General conclusions with regard to the extent of freedom of expression enjoyed by parliamentarians under the ECHR remains difficult: on the one hand, limitations on freedom of expression in political discourse require 'the closest scrutiny' (Castells). On the other hand, being a parliamentarian alone does not confer upon an individual a greater freedom of expression (Keller) and may even lead to a greater duty of care. Lastly, the Court does not seem willing to afford any protection to hate speech or incitement to discrimination (Féret). We will see in the course of our case study of parliamentary immunity in the Netherlands, and especially in the account of recent debates, that the inconclusiveness of ECtHR case law in this matter is problematic. Politicians, and parliamentarians in particular, are caught in a nexus between greater freedom and greater responsibility, between being equal citizens before the law and being slightly 'more equal' than others due to their status. 
Nevertheless, it is safe to conclude that the Court employs a functional approach, similar to the one observed in connection with Article 6, to issues involving parliamentarians and Article 10 of the Convention. First, where parliamentary functions are not at issue, being a member of parliament merits no special treatment. A difference can be observed, however, in the definition of parliamentary functions: the Court used a relatively conservative, institutional definition of 'parliamentary functions' in case law relating to Article 6 (Cordova, Syngelidis). In issues relating to Article 10, it affords much greater relevance to the political nature of utterances, or their being in the general interest, than to the institutional aspect of being a member of parliament (Castells, Öllinger, Karhuvaara).

\section{The Immunity Regime of the European Parliament}

\subsection{A Combined Immunity Regime: $27+1$}

Members of the European Parliament (MEPs) benefit from a very complex immunity system which dates back to an era when the Parliament was not directly elected but was composed of delegates from the national parliaments of the Member States. ${ }^{71}$ This system is laid down in Articles 8 and 9 (formerly Articles 9 and 10) of Protocol No. 7 to the Treaty on European Union. The crucial first paragraph of Article 9 has been inspired by the system of immunity for members of the Parliamentary Assembly (until 1974: Consultative Assembly) of the Council of Europe, and which still reveals its structure as a gathering of delegates from national parliamentarians. ${ }^{72}$ Articles 8 and 9 of Protocol No. 7 read as follows:

\section{Article 8}

Members of the European Parliament shall not be subject to any form of inquiry, detention or legal proceedings in respect of opinions expressed or votes cast by them in the performance of their duties.

\section{Article 9}

During the sessions of the European Parliament, its Members shall enjoy:

(a) in the territory of their own State, the immunities accorded to members of their parliament;

(b) in the territory of any other Member State, immunity from any measure of detention and from legal proceedings.

Immunity shall likewise apply to Members while they are travelling to and from the place of meeting of the European Parliament.

This was the case until 1979.

For the immunity system of the Parliamentary Assembly of the Council of Europe, see: Statute of the Council of Europe, Art. 40; General Agreement on Privileges and Immunities of the Council of Europe, Arts. 13-15; Protocol thereto, Arts. 3 and 5. For the historical link between the immunity system of the European Parliament and that of the Parliamentary Assembly, see Harms 1968. 
Immunity cannot be claimed when a Member is found in the act of committing an offence and shall not prevent the European Parliament from exercising its right to waive the immunity of one of its Members.

Article 8 of the Protocol is relatively straightforward. It provides for absolute nonaccountability in the exercise of a member's functions. This provision is thus similar or identical to non-accountability as it exists in all Member States (although it is frequently limited to votes and opinions expressed in parliament proper).

The complexity of the European Parliament's (EP) immunity system stems from Article 9, which, depending on the location of a member at the relevant time, either provides an MEP with inviolability equal to that enjoyed by national parliamentarians of his home Member State or with a broad 'European' inviolability that prohibits 'any measure of detention' and 'legal proceedings' against him. ${ }^{73}$ In fact, this means that the inviolability system of Article 9 is a combination of the systems of all 27 (28 after the accession of Croatia in 2013) Member States of the EU and the proper inviolability of the European Parliament.

In theory, whether and in how far a member of the European Parliament is inviolable in a specific case depends on whether the EP is in session. However, it follows from case law of the ECJ (now CJEU) that the European Parliament holds sessions for a 12 month period ${ }^{74}$ and the responsible committees have repeatedly declared that immunity applies during the entire time of the mandate, starting with the declaration of election results. ${ }^{75}$

The exact scope of the immunity depends, first, on the nationality of the member concerned ${ }^{76}$ and, second, on the state in which the alleged criminal act or the fact to which legal proceedings relate has occurred. Article 9(3) provides for the exception of flagrante delicto which can be found in all inviolability provisions of European states. Lastly, the European Parliament has a right to waive inviolability on request, pursuant to Article 9(3).

\subsection{A Discriminatory System}

Where an MEP's behaviour gives rise to legal proceedings against him in 'his own' Member State, Article 9(1)(a) affords him the same immunity as national

73 It has long been doubted whether the term 'legal proceedings' had to be interpreted as meaning both criminal and civil proceedings, since none of the six founding members of the European Communities, which initially adopted the Protocol, provided for inviolability from civil proceedings in their national systems. However, since 2003, the European Parliament has in several cases asserted inviolability from civil proceedings against its members where it was of the opinion that the amount which the members would potentially have to pay in civil damages was such that it had to be considered punitive in nature; see Offermann 2007.

74 Wagner v. Fohrmann and Krier, ECJ 12 May 1964, Case 101/63; Wybot v. Faure, ECJ 10 July 1986, Case 149/85.

75 Offermann 2007, p. 7.

76 The phrase 'their own state' in Art. 9(1)(a) refers to the state in which a member has been elected, thus strictly speaking not the state of which he is a national. After all, there may be cases of dual nationality or, where election rules permit this, cases in which a national of one Member State is elected in another. 
parliamentarians of that Member State would enjoy in equal circumstances. However, if the relevant act is committed in another Member State, the member concerned enjoys full immunity from legal proceedings in civil and criminal matters - thus a very broad variant of inviolability - by virtue of Article 9(1)(b) of the Protocol. Where the act is committed while the member is travelling to or from Brussels or Strasbourg, regardless of whether or not he is still on the territory of his own Member State at the precise moment of the act, the 'European' immunity under (b) applies in the same way.

Since the inviolability rules of the Member States are very diverse - the UK and the Netherlands do not provide for inviolability at all - a certain inequality between members from different states is inherent in this system. An example may make this more evident: imagine an MEP from Poland giving a television interview in his home country, in which he makes insulting or defamatory statements about a person. In this scenario, he will enjoy the same immunity as do members of the Polish Sejm and Senate. Since the Polish Constitution affords members of the national parliament broad inviolability, the MEP cannot be held criminally liable. If the same Polish member of the European Parliament gives the same interview in the Netherlands, he will enjoy full immunity pursuant to Article 9(1)(b) of Protocol No. 7. However, if a Dutch member of the European Parliament gives the same interview in the Netherlands, where no system of inviolability exists, he will be criminally liable like any other citizen. This is, again, different, if the Dutch MEP gives the interview abroad, or on a train to Brussels or Strasbourg.

This situation is clearly discriminatory. The European Parliament has therefore suggested that changes be made to the system of immunity, to the effect that all members would be subject to the same rules. However, to date, the relevant rules of Protocol No. 7 have not been amended. 77 The immunity rules cannot be changed by the European Parliament unilaterally, because the Protocols to the Treaties form an integral part, pursuant to Article 51 of the Treaty on European Union (TEU). Therefore, any amendment to Protocol no. 7 would require a cumbersome Treaty revision procedure under Article 48 TEU.

77 As early as 1983, the EP resolved to propose an amendment of the immunity rules laid down in the Protocol (OJ C277, 17 October 1983, p. 135). The Bureau of the EP submitted an initial proposal to amend the immunity system to the Commission. After making amendments, the Commission forwarded the draft to the Council (Doc. 1-1442/84, COM(84) 666). Having received the draft from the Council for consultation, the Legal Affairs Committee of the EP drew up a detailed report in which it explained the discriminatory effects of the current immunity rules (the Donnez Report, A2-0121/86) and the EP adopted a resolution to suggest amendments to the draft (OJ C99, 13 April 1987, p. 43). However, the Council never adopted the proposal. Also later calls by the EP to amend the immunity system remained unheard (OJ C158, 17 June 1991, p. 258). In 2003, the Committee on Legal Affairs and the Internal Market drew up a Draft Statute for Members of the European Parliament (see the Rothley Report, A50193/03), which contains provisions for a unified system of non-accountability and limited inviolability that only prohibits restrictions on the liberty of members, but not legal action against them. The Draft Statute provides that this new system shall enter into force upon the repeal of Arts. 9 and 10 (now Arts. 8 and 9) of Protocol No. 7. However, the system contained in the Draft Statute was not endorsed by the Commission and later dropped by Parliament. 


\subsection{Waiving or Defending European Inviolability}

According to Article 9(3) of the Protocol on Privileges and Immunities, the EP has the right to waive a member's inviolability as long as it concerns a case under Article 9 of the Protocol (since the proper 'European' non-accountability afforded by Article 8 is absolute and cannot be waived). The procedure for waiving inviolability is laid down in Rules 6 and 7 of the Rules of Procedure of the European Parliament. According to these rules, the competent authority of a Member State may submit to the EP a request to waive the immunity of one of its members. This request is referred to a committee, which examines the case and draws up a report and a proposal for a decision. On the basis of this proposal, the plenary Parliament takes a vote on whether or not to waive immunity.

Over time, a number of principles of parliamentary practice have crystallised. Offermann, in his detailed report on the immunities of the EP, summarises these principles as follows: First, the immunities are treated as an institutional privilege. This means that they are applied so that they protect the independence of parliament as a body through the protection of its members. Therefore it is of secondary concern whether the act to which legal action against a member relates has been committed before the beginning of his mandate. ${ }^{78}$ From the principle of immunity as an institutional privilege, it also follows that individual MEPs do not have the right to renounce their immunity. This is also made clear by Article 9(3) of Protocol No. 7 itself, which explicitly reserves the right of waiver to the Parliament as a whole. Next, as we have already seen, immunity is effective for the duration of a member's mandate, since the EP is deemed to be continuously in session. Finally, the most interesting result of parliamentary practice is the way in which the European Parliament has tried to remedy the discriminatory effects of the reference to national immunity rules in Article 9(1)(a). Offermann explains the approach of the EP as follows:

\footnotetext{
The fact that letter (a) of Article [9] of the PPI refers to immunities granted to Members of national parliaments does not mean that the European Parliament may not establish its own rules, its own case law, as it were; as for the waiver of parliamentary immunity, the notion of parliamentary immunity itself, which is identical for Members of national parliaments and of the European Parliament, must not be confused with the procedures for waiver of parliamentary immunity, which are a matter for each parliament concerned. These rules, which are the outcome of decisions taken on requests for the waiver of immunity, tend to create a coherent notion of parliamentary immunity which should, as a matter of principle, be entirely separate from the various practices employed in the national parliaments. If that were not the case, the disparities between Members of one and the same parliament would be accentuated on the grounds of their nationality. ${ }^{79}$
}

Thus, the European Parliament tries to solve the discriminatory situation caused by the discrepancy between the material immunity rules of the Member States by 
asserting the right to decide autonomously, without regard to national rules and practice, whether or not to waive immunity. The obvious result of this approach is that parliament is not easily inclined to waive a member's immunity, even where it probably would be waived - or deemed not to exist - in cases involving a national parliamentarian.

Offermann lists four essential criteria according to which the EP takes its decision in a particular case. First, where legal action against the member relates to any form of political activity, immunity must not be waived. Second, immunity is also not waived in the presence of fumus persecutionis - the presumption that legal action is politically motivated. Third, where a member is charged with particularly serious crimes (such as rape or murder), his immunity is to be lifted. Lastly, the European Parliament takes into account whether the offence concerned is considered equally serious in different Member States.

Along with the power to waive the immunity of one of its members, the European Parliament may also decide to do the opposite, that is, to assert or 'defend' immunity. It can do so with regard to both layers of immunity, nonaccountability ex Article 8 and inviolability ex Article 9 of Protocol No. 7. The Parliament usually makes such an assertion upon a request by a member against whom legal proceedings have been initiated in a national court. ${ }^{80}$ The assertion takes the form of a resolution which does not have the power to bind the authorities of a Member State directly. Nevertheless, solidarity and cooperation with the European Parliament is expected from all national judges pursuant to Article 4(3) TEU (formerly Article 10 TEC). This means that an assertion of immunity by the Parliament has to be taken into account, but, especially with regard to nonaccountability pursuant to Article 8 of the Protocol, such a decision is not legally authoritative, since the existence of immunity in a particular case is to be established by the trial court itself (see next section). With regard to inviolability under Article 9, the decision of the Parliament also has no binding force, but it may put a certain 'interpretative pressure' on the national courts to afford the MEP concerned the protection of the national inviolability rules. However, what if no such rules exist?

Carla Berkhout has recently argued that the approach of the EP with regard to its power to waive or defend immunity can be used as a means to circumvent the problem of restrictive (or non-existent) national inviolability rules. ${ }^{81}$ She asked the hypothetical question: what would have happened if Geert Wilders, the Dutch right-wing populist, had been a member of the EP when he was prosecuted for extra-parliamentary hate speech and insult? This raises an interesting yet highly speculative issue, since the Dutch immunity system merely provides for free speech in parliament and nothing beyond - in particular, there is no inviolability for any act or utterance outside parliament. Imagine that Dutch prosecutors wish to bring legal proceedings against a Dutch MEP for having committed, in his home Member State, a criminal act or utterance which is not covered by non-accountability

See Rule (6)(3) of the Rules of Procedure of the EP. Berkhout 2009, p. 2057 et. seq. 
pursuant to Article 8 of the Protocol. In such a situation, Article 9(1)(a) provides that the MEP concerned enjoys the same immunity as members of the national parliament of his home Member State. In the Netherlands, this would mean, strictly speaking, that he enjoys no immunity, since inviolability does not exist in the Dutch system. Would the prosecutors nevertheless be required to request the lifting of immunity (inviolability) under Article 9 of the Protocol in order to launch legal proceedings against this MEP?

On the one hand, this would be paradoxical, since an immunity which does not exist cannot be lifted. On the other hand, a decision of the Dutch authority not to file a lifting request would potentially undermine the authority of the European Parliament to take the decision whether or not to lift immunity autonomously and to detach this decision from national rules. Berkhout assumes that the national authorities would not be inclined to take the risk to simply ignore the EP. In addition, it is likely that the member in question would request the European Parliament to assert his immunity. If he does so and the EP decides to follow his request, the principle of sincere cooperation ex Article 4(3) TEU would not make it easy for national courts to act against its decision. ${ }^{82}$

Hence, with regard to the Wilders scenario or other cases which fall under national inviolability in some Member States but not in others, it could thus be conceivable that that the European Parliament could try to 'create' immunity for its members by using its prerogative to decide on the lifting of immunity or to assert it in a resolution. Berkhout observes that the European Parliament defends the immunity of its members 'with fire and sword', as evidenced by the fact that it agrees to lift it in less than 20 per cent of the cases in which it is requested to do so. ${ }^{83}$ But is this way of 'creating' immunity where none exists pursuant to national rules a realistic possibility? On the one hand, whether the European Parliament would actually try to even out the 'inviolability gap' caused by systems like the Dutch (or British) along this route is open to speculation. What is certain, however, is that this would clearly violate both the letter and the spirit of Article 9(1)(a) of Protocol No. 7, whose intention - however problematic otherwise - is to grant any MEP the same inviolability as is enjoyed by national parliamentarians in his home Member State. In Berkhout's scenario of a Dutch MEP who is to be prosecuted in his home Member State for a crime which Dutch parliamentary immunity does not cover, the Dutch courts would therefore certainly be at liberty to try the member in question. In order to do so, they would not be obliged to request the EP to lift the MEP's inviolability, since there is no a priori case for the existence of inviolability in the first place. But even if they did make such a request and it would be denied, or if the EP decided to assert the (pseudo-)inviolability of its member on his own request, such a decision would not have the power to bind the national courts. Finally, where a national court is confronted with a decision of the EP to defend the fictitious inviolability of an MEP, that court could refer the matter to the Court of Justice of the European Union (CJEU) by means of a preliminary question on the interpretation of Article 9 
of the Protocol. It appears highly questionable whether the CJEU would be inclined to enforce inviolability where it is manifestly incompatible with the wording of Article 9(1)(a) of the Protocol. Even though there is no case law yet on inviolability, it is clear that the Court of Justice will leave the material decision as to whether immunity exists in a particular case to the national courts and will merely provide guidance on the correct interpretation of European rules. In doing so, it is likely that the CJEU would not go beyond the wording of Article 9(1)(a). This is supported by the restrictive interpretation that the Court has given to non-accountability ex Article 8 of the Protocol, as the next section will show.

\subsection{The CJEU and the Scope of European Non-accountability}

Thus far, we have primarily been concerned with the combined immunity system of Article 9(1)(a) and (b) of Protocol No. 7. Even though this system summarily refers to the 'immunity' enjoyed by parliamentarians in the Member States - thus to the entirety of immunities existing there - it is clear that Article 9 deals with inviolability only. Apart from cases in which a parliamentarian holds a dual mandate, it is inconceivable how a member of the European Parliament could perform an act or make an utterance that is covered by national non-accountability which, after all, relates exclusively to the inner dealings of the national parliaments. This is different under Article 8 of the Protocol, which grants members of the EP absolute non-accountability for 'opinions expressed [...] in the performance of their duties'. The obvious question, therefore, is what exactly falls within the scope of parliamentary duties?

It has been observed that the CJEU has, for a very long time, carefully avoided this question, and in fact any substantive question with regard to parliamentary immunity. ${ }^{84}$ The only two decisions of interest in this respect are those in Marra ${ }^{85}$ and, most recently, Patriciello. ${ }^{86}$ In the former case, two persons had brought civil claims for damages against Mr Marra MEP, who had allegedly insulted them in leaflets which he had distributed in his native Italy. While on trial in a local court, Mr Marra had requested the EP to defend his immunity and this request was granted. However, for unknown reasons, the resolution of the EP had not reached the Italian Court. In a preliminary question to the CJEU, this Court therefore asked, first, whether it was required to request the lifting of immunity and, in the absence of a decision by the European Parliament, whether it was competent to rule on the scope of immunity. These questions did not, however, distinguish between the two forms of immunity contained in Articles 8 and 9 (then Articles 9 and 10) of the Protocol, respectively. With regard to the circumstances of the case, the CJEU assumed that the immunity at stake was that of Article 8 (non-accountability for opinions expressed in the exercise of a member's functions) ${ }^{87}$ It observed that this

$84 \quad$ Mehta 2012, p. 314.

85 Alfonso Luigi Marra v. Eduardo De Gregorio and Antonio Clemente (preliminary ruling), CJEU 21

October 2008, joined cases C-200/07 and C-201/07.

86 Aldo Patriciello, CJEU 6 September 2011, case C-163/10.

$87 \quad$ Ibid., para. 31 
particular immunity was absolute and could not be waived by the European Parliament; neither did the Parliament have the power to determine whether the conditions for the application of Article 8 are met in a specific case. This decision falls within the exclusive competence of the national court, which is thus not obliged to request a waiver. ${ }^{8}$ However, where the European Parliament has been requested to defend its member's immunity, the duty of sincere cooperation obliges the Court to stay proceedings until the EP has reached a decision. However, the national judge is not obliged to follow that decision. ${ }^{89}$

Accordingly, it is for the national judge to rule on the scope of European nonaccountability. The CJEU's judgment in Marra did not provide any guidance as to the definition of opinions expressed in the performance of an MEP's duties - this issue was not raised by the question of the referring court and it can be assumed that the CJEU happily avoided it. However, it was addressed in the Opinion of Advocate General Maduro, who suggested a test of two criteria. Since his Opinion is one of very few authoritative texts on this important question in an EU context, it merits a somewhat lengthy quote:

First, the opinion at issue in any given case must be about a genuine matter of public interest. While a statement on an issue of general concern will be covered by the absolute privilege guaranteed by Article 9 regardless of whether it is made inside or outside the premises of the European Parliament, this privilege may not be relied upon by MEPs in the context of cases or disputes with other individuals that concern them personally but have no wider significance for the general public. [...] I want to be clear in this respect: the question whether or not such a statement contributes to a public debate is not to be determined by the style, accuracy or correctness of the statement but by the nature of the subject-matter. Even a possibly offensive or inaccurate statement may be protected if it is linked to the expression of a particular point of view in discussing a matter of public interest.

Second, a distinction must be drawn between factual allegations against particular individuals and opinions or value judgments. As the European Court of Human Rights has held 'while the existence of facts can be demonstrated, the truth of value judgments is not susceptible of proof. The requirement to prove the truth of a value judgment is impossible to fulfil and infringes freedom of opinion itself, which is a fundamental part of the right secured by Article 10 [ECHR]'. When a Member of Parliament makes a value judgment about a matter of general importance, no matter how upsetting or offensive some people may find it, he should, in principle, be able to avail himself of absolute privilege. However, Article 9 of the Protocol, which expressly refers to 'opinions', does not cover statements made by MEPs which contain factual allegations against other individuals. ${ }^{90}$

According to Advocate General Maduro, it thus falls within the duties of an MEP to make statements and voice opinions about matters of general interest, also where this is done in a non-parliamentary context. He further draws a line between 'value 
judgments' and 'factual allegations'; the former must fall within the sphere of absolute non-accountability, whereas the latter do not because they can be falsified. Interestingly, Maduro does not attach any importance to a material link between the utterances of an MEP and his specific activity in the Parliament. In this sense, what he suggests is actually a form of political immunity detached from parliament as an institution, an idea to which we will come back in our Dutch case study. In the absence of a larger amount of case law, it is hard to assess the feasibility of this approach with certainty. ${ }^{91}$ It is, however, evident that it would make the scope of absolute non-accountability enjoyed by MEPs much broader than it is in all or most of the Member States.

In Patriciello, the only case to date in which the CJEU has considered the question what constitutes an opinion expressed in the exercise an MEP's duties directly, Advocate General Jääskinen rejected the test proposed by Maduro and has instead suggested an 'organic' approach. By this he means

that the Court should introduce a criterion specific to the nature of the duties of a Member of the European Parliament, on the basis of the case-law of the European Court of Human Rights. This criterion links substantive immunity not to the content of a Member's comments, but rather to the relationship between the context in which those comments are made and the parliamentary work of the Parliament. ${ }^{92}$

Thus, the decision whether an opinion has been expressed in the exercise of an MEP's duties should still be taken on the basis of the content of that opinion, but this content should be materially linked to the actual work of the EP, and not to the concept of public interest. As Jääskinen himself points out, this approach is inspired by that taken by the European Court of Human Rights in its case law regarding parliamentary immunity.

The circumstances of the case in Patriciello were the following: an Italian MEP had observed a municipal police officer issuing tickets to several drivers who had parked their cars in contravention of the relevant regulations on a parking lot close to a neurological clinic. The MEP had then accused her of falsifying the relevant times, which amounts to the criminal offence of forgery. He was subsequently charged with making false accusations against a public official. Upon his request, the MEP asserted his immunity under Article 8 of Protocol No. 7. The resolution states that

Think, for instance of Geert Wilders' statement that the Quran is a 'fascist book'. Is calling something 'fascist' a value judgment or a factual allegation? And in either case, in the context of the Quran, which is the basis of a religion whose core dogma is that this book is the word of God, can a statement about the book be distinguished from a statement about Muslim believers? Opinion of AG Jääskinen in Patriciello, case C-163/10, delivered on 9 June 2011, para. 89. 
[a]s a matter of fact, in his statements, Mr Patriciello merely commented on facts in the public domain, the rights of the citizens to have an [sic] easy access to a Hospital and to the healthcares [sic], which had an important impact on the daily life of his constituents. ${ }^{93}$

The trial court submitted to the CJEU the question whether making false accusations (in abstracto) constituted an utterance protected by non-accountability ex Article 8.

Even though it is obvious that the accusations which Mr Patriciello had made against the Italian police officer would not have passed the test suggested by Advocate General Maduro in Marra, since they were of a factual and thus falsifiable nature, the Court chose to adopt a more restrictive approach. According to the judges in Luxembourg, non-accountability ex Article 8 is 'in essence intended to apply to statements made by those members within the very precincts of the European Parliament'. Nevertheless it is possible that it also covers opinions expressed outside these precincts, since this depends 'not on the place where the statement was made, but rather on its character and content' ${ }^{94}$ However, the Court also acknowledges the harsh consequences which absolute inviolability has on those who wish to bring legal proceedings against a member. It therefore holds that 'the connection between the opinion expressed and parliamentary duties must be direct and obvious'. ${ }^{95}$ This was of course clearly not the case with regard to the opinion which Mr Patriciello had expressed at the parking lot. We can thus see that the CJEU essentially followed the Opinion of Advocate General Jääskinen and adopted his 'organic' test, which strongly resembles the functional test employed by the ECtHR. ${ }^{96}$

The ruling of the CJEU has been criticised as creating 'a real danger that the European "public space" should become one not of vibrant discussion and competing narratives, but one in which expression is chilled for fears of civil or criminal prosecution $[\ldots]^{\prime} \cdot{ }^{97}$ One may or may not agree with this assessment, but in any event it should be borne in mind that the factual circumstances of the case were such that a ruling which would have obliged the trial court to give Mr Patriciello the benefit of non-accountability was virtually unimaginable from a judicial point of view, even though the EP was of a different opinion. Since Patriciello was the only decision in which the CJEU was called upon to interpret Article 8 of Protocol No. 7, it cannot be ruled out that the Court of Justice will refine or alter its definition of an 'opinion expressed in the exercise of an MEP's functions' on a future occasion, where the underlying case offers more room for controversy. For the time being,

Aldo Patriciello, CJEU 6 September 2011, case C-163/10, para. 12.

Ibid., paras. 29-30.

Ibid., para. 35.

It should be noted that we referred to the ECHR's approach as 'functional', since the decisive factor is the connection between the act that is the basis of proceedings against a parliamentarian and his parliamentary functions. AG Jääskinen, however, calls the approach suggested by AG Maduro 'functional' because it refers to the function of an MEP's statement as a contribution to public debate. He characterises his own approach as 'organic'.

97 Mehta 2012, p. 8. 
however, European non-accountability must be interpreted according to the test suggested by Advocate General Jääskinen.

\subsection{The Immunity System of the European Parliament: Conclusion}

Like many national systems of parliamentary immunity, that of the European Parliament is composed of two layers: (a) absolute non-accountability pursuant to Article 8 of Protocol No. 7 and (b) a combination of the immunity regimes of the Member States and a broad 'European immunity' pursuant to Article 9 of that Protocol. Since not all Member States grant their parliamentarians inviolability, the combined system under Article 9 discriminates between MEPs from different Member States. The European Parliament tries to remedy this discriminatory effect by making use of its discretionary power to waive or assert immunity, but there is at least a theoretical possibility that this method would give rise to new problems if it were applied so as to grant MEPs inviolability even where it does not exist pursuant to the material rules of the Member State concerned. Even though it cannot be ruled out that the European Parliament would, in such a case, attempt to 'create' inviolability by asserting it, it must be doubted whether this attempt would be successful, both in the national courts and before the CJEU.

Article 8 of Protocol No. 7 provides MEPs with absolute non-accountability for opinions expressed in the exercise of their duties. Whether an utterance falls within this category is ultimately for the national trial court to decide. However, the CJEU has provided some guidance in this question. It did not adopt the wide interpretation suggested by Advocate General Maduro in the case of Marra, which would have rendered $\mathrm{MEP}^{\prime} \mathrm{s}$ unaccountable for opinions which relate to matters of public interest and do not amount to factual accusations. Instead, the Court found an approach very similar to that of the European Court of Human Rights: an opinion expressed by an MEP must bear a 'clear and obvious' connection with the actual work of the European Parliament in order to fall within the scope of Article 8 of the Protocol. At least with regard to non-accountability, the approach of the CJEU is thus congruent with that of the ECtHR.

\section{Concluding Remarks on Parliamentary Immunity in Europe}

In the introduction to our analysis, we asserted that the relevance of the European dimension of parliamentary immunity lies in its capacity of having a certain normative force which can further our understanding of parliamentary immunity as a concept. This normative force stems from the authority which in particular the decisions of the two European courts have across national borders. To a more limited extent, it also derives from the degree of consensus among both national and European systems which is revealed in the reflection and argumentation which underlies these decisions and the systems themselves.

In concrete terms, we can draw three basic conclusions which are closely interrelated and which apply to all national systems of parliamentary immunity in Europe and to that of the European Parliament. First, the purpose of parliamentary 
immunity is to protect the work of parliament. Its character is that of an institutional and decidedly not personal privilege. This seems to be a trite statement, but it is central to all reasoning, judicial and otherwise, about the concept of parliamentary immunity. Where immunity is applied, it interferes with basic rights (especially access to court and the right to an effective legal remedy) and with the fundamental principle of equality. However, this interference is accepted by the courts and the European states in deference of the higher legal value that lies in the unimpeded functioning of parliaments.

The second conclusion follows directly from the first: rules of parliamentary immunity are not sacrosanct. Their validity vitally depends on whether they are necessary with regard to their purpose of protecting parliament. This results in the functional approach with which both the ECtHR and the CJEU assess and interpret immunity. In short, in all cases which raise the question whether an act or utterance is protected by immunity or whether the interference with the rights of a third party by virtue of immunity is justified, the decisive criterion is the existence of a connection between the act, utterance or interference and the work of parliament. As a rule, the weaker this connection, the less the application of immunity is justified.

As a third conclusion, it also follows from the institutional nature of parliamentary immunity that it is not tantamount to political immunity and must not be confused with it. It is true that the European legal order, including the Convention on Human Rights, attaches great value to unimpeded political debate and free speech in matters of public interest. It is also true that the European Court of Human Rights has emphasised the importance of public debate in judgments relating to the freedom of expression of parliamentarians. Nevertheless, it cannot be established that parliamentary immunity confers on its beneficiaries a higher degree of freedom of expression beyond what is necessary for the functioning of parliament. Bluntly, if parliamentarians are afforded a wider margin of freedom of expression beyond the confines of their parliamentary work, this is not based on their status as parliamentarians but on the fact that they habitually engage in political speech. In reality, both of these characteristics are of course intimately linked with each other. Nevertheless we must differentiate between them for the purpose of assessing the concept of parliamentary immunity.

These three very general conclusions, or rules, form both the common essence of all the immunity systems which exist in Europe and what might be called their 'normative shell'. Perhaps this merits a hypothesis which can be tested in the three case studies which follow: despite the fact that the historical origins, the political background and the theoretical scaffold surrounding national systems of parliamentary immunity differ considerably between European states, these systems are evolving so as to fit this normative shell. For one system, this may mean that the scope of parliamentary immunity is gradually reduced, for another, that it may be broadened (for example because the interpretation of 'parliamentary functions' is subject to change). However, no system is likely to display in its (recent) development a tendency to exceed the European standard. 
Chapter 3

\section{PARLIAMENTARY PRIVILEGE IN THE UNITED KINGDOM}

\section{Introduction}

\subsection{Structure of this Case Study}

This introduction (part one) to the first case study will be followed by three component parts. The second part will deal with the origins and the historical development of parliamentary privilege in Britain, starting with a very concise recount of the origins of Westminster Parliament, followed by a brief historical discussion of each of the individual privileges, and a discussion of instances of conflict between the House of Commons and the House of Lords.

Part three will discuss the relationship between lex parliamenti and lex terrae and thereby explore the theoretical foundations of the law of parliamentary privilege, tracing its development up to the current stage, and end with an attempt to draw conclusions as to the legal nature of the law of the British Parliament.

Part four will be devoted to the law of parliamentary privilege as it stands today, a discussion of its interpretation and application and of the legal problems arising in its modern context. In this part, attention will also be given to the most recent developments of parliamentary privilege in the UK.

The final part of this case study will contain the conclusions which can be drawn from our examination of parliamentary privilege in the UK.

\subsection{Parliamentary Privilege in the UK}

This case study is concerned with the system of parliamentary immunity of Westminster Parliament, the central parliament of the United Kingdom of Great Britain and Northern Ireland. In the context of the UK, parliamentary immunity comes in the form of parliamentary privilege, a term which in itself hints at the peculiar position of the British version of parliamentary immunity vis-à-vis the law. Privilege is not simply the British synonym for parliamentary immunity; it also bears reference to the special status of Westminster Parliament and the law 
governing parliamentary affairs within British law. In many respects, this status is indeed 'privileged', because it is governed by a separate legal system. ${ }^{1}$ Parliamentary privilege must hence be understood to carry a somewhat wider meaning than merely the exemption from application of the law to Parliament and its members. The definition of privilege most commonly referred to is that offered by Erskine May's Treatise on The Law, Privileges, Proceedings and Usage of Parliament:

Parliamentary privilege is the sum of the peculiar rights enjoyed by each House collectively as a constituent part of the High Court of Parliament, and by members of each House individually, without which they could not discharge their functions, and which exceeds those possessed by other bodies or individuals. ${ }^{2}$

This broad definition shall serve as the starting point for the examination of parliamentary privilege. For all three studies, we will inquire into the origins and history, the legal nature and the material content of the system of Parliamentary immunity. In addition to these general research questions, it is necessary for a good understanding of the UK's system of parliamentary privilege to examine the concept of the High Court of Parliament - of its legislature as a court of law. As will be shown, this concept is key to understanding the system - but also to legal problems and conflicts which have arisen throughout its long history.

It will be shown in the course of this case study that privilege is not merely one of the features of British Parliamentary law but in fact lies at the very heart of the constitutional structure, closely related to the prevailing doctrine of Parliamentary sovereignty. For the wider purpose of comparing British parliamentary privilege to the immunity systems of France and the Netherlands, it is therefore crucial not to limit our observation to the positive law of parliamentary privilege as we find it today but to also elaborate on the historical roots and development of privilege, as well as on its theoretical background. Attention will also be paid to legal problems arising in the context of parliamentary immunity. In particular, we are interested in the British solution to the fundamental dilemma of parliamentary immunity, the balancing act between the potentially opposing needs of protecting Parliament and guaranteeing the rule of law. Closely related to this theme are on-going attempts to clarify and reform the privilege system, which will also be discussed.

1 The word 'privilege' derives from the Latin privilegium which is a composition of the words privus (meaning separate or apart) and lex (law). This chapter is to show that this is not merely a point of semantics but that it is possible to see the lex et consuetudo parliamenti is a legal system in its own right.

$2 \quad$ McKay et al. 2004, p. 75. This standard volume will hereinafter be referred to as 'Erskine May'. 


\subsection{Delineation}

This chapter has a vast territory to cover. It appears necessary, therefore, to make a few delineatory remarks in advance. First, this chapter will focus solely on the system of privilege of Westminster Parliament. During its long and varied history, the political and geographical nature of the realm of the kings of England and their Parliament has, of course, changed considerably, and many times - geographically, in its administrative structure, and in Parliament's constitutional position. While Westminster Parliament is often taken to be 'the mother of all parliaments', it is not the only one in that realm. However, it would exceed the scope of this study to consider in much detail other parliaments or parliamentary assemblies, such as the Scottish Parliament, the Northern Ireland assembly, or (former) colonial and Crown dependency assemblies, nor Commonwealth parliaments. For our purposes it is sufficient to limit the examination to Westminster Parliament, since most of the peculiarities of Westminster-type parliamentary immunity originate here. ${ }^{3}$ Moreover, the devolution parliaments do not have systems of parliamentary immunity that are independent of the central parliament at Westminster. ${ }^{4}$ Commonwealth parliaments, such as the parliaments of Australia and New Zealand, are for the most part designed after the model of Westminster Parliament, though of course the respective systems of parliamentary immunity do display some differences and peculiarities due to diverging (constitutional) legislation after gaining independence, and due to diverging case law. Interestingly, the clause of the United States Constitution which grants members of Congress nonaccountability for speech in the legislature ${ }^{5}$ is in its wording almost identical to Article 9 of the Bill of Rights 1689, the most prominent piece of legislation for freedom of speech in Westminster Parliament, and had, according to Chafetz, barely led to debate during the drafting of the US constitution. ${ }^{6}$ Thus, while the US system of legislative privilege is most certainly worth its own discussion, it is not strictly necessary for the purposes of this study.

While parliamentary privilege in jurisdictions other than the United Kingdom is thus not the subject of this chapter, it will be noted that some of the case law and statutory legislation that will be considered in its course does originate from other Commonwealth jurisdictions. This occurs where the case law or statutes concerned have been used, discussed in, or have had a direct impact on the UK's law on privilege. Case law and statutory provisions that do not belong to the UK will

3 For example, Art. 9 of the Bill of Rights 1689 is still applicable in some Commonwealth jurisdictions and has shaped non-UK privilege law to a considerable degree.

Legal provisions which serve to protect the Scottish Parliament and the Northern Ireland Assembly do exist (See sections 40-43 of the Scotland Act 1998; Section 50 of the Northern Ireland Act 1998), however, like these assemblies themselves they are entirely dependent upon devolution legislation, which Westminster Parliament could hypothetically repeal, thus their privileges may be seen as a mere derivative.

5 Art. I(6), clause 1 of the US constitution.

$6 \quad$ Chafetz 2007, p. 89 et seq. 
therefore not be discussed in order to reach conclusions on parliamentary privilege in their jurisdictions of origin.

A second delineatory remark is expedient with regard to the approach of this chapter to the history of the British Parliament. For the purposes of this chapter, it is necessary to recount at least in part the long history of parliamentary privilege. However, it would neither be feasible nor appropriate for this chapter to attempt an exhaustive account of this history and the whole body of law and theory of Parliament in general. This is to be found in sufficient detail in the sources cited. ${ }^{7}$ Rather, the purpose of the present chapter is to trace the cornerstones of the development of privilege and touch upon the history of Parliament where it serves this purpose.

\section{The History of Parliamentary Privilege}

As briefly outlined in the introduction, it is the aim of this chapter to give an account of the positive law of parliamentary privilege as it exists at this moment, but to contextualise it by identifying its position within the constitutional system and vis-à-vis the law of the land. The following illustrates that it is impossible to do so without at least some knowledge of both the historical development of privilege and, more broadly, that of the Westminster parliamentary system as a whole. The reason for this is that the history of Westminster parliamentary privilege is very closely entangled with the concept of parliament as it is understood in British law and the role of Parliament within the constitutional structure. The nature and extent of privilege, as will be shown, is for a large part attributable to the origins of Parliament and to the circumstances under which its two Houses historically had to operate, and the theoretical foundation, on which the law of privilege is built, also stems from its early days. We will therefore first recount, very concisely, those parts of the history of Parliament which are relevant to our purpose, and then proceed to the history of privilege.

\subsection{The Origins of Parliament}

The earliest institution which may be recognised as a forebearer of what we know today as the Parliament of the United Kingdom of Great Britain and Northern Ireland is the central assembly of highest-ranking feudal lords, or tenants-in-chief, and leading clergymen under the Norman Kings, as existed following the Norman conquest of 1066. This assembly is generally referred to as the Curia Regis or King's Council.

The feudal system of government of the Norman era featured a system of complex socio-political structures based on, first and foremost, the lord-tenant relationship. At the top of what may be called the pyramid of feudal power stood

The standard work on all aspects of British Parliament and the body of law pertaining to it is Erskine May's Treatise (McKay et al. 2004), which is also an invaluable source for any examination of parliamentary privilege. 
the King, who, in principle, owned all the land in his realm. However, similar to feudal systems all over the European continent at the time, the King did not govern the land by direct rule. Instead, the land, divided into fiefdoms, was granted to vassals (tenants) in return for an oath of fidelity and their service (for example, in the form of military services) and payments (in the form of taxes). The tenants-inchief, usually members of the highest-ranking nobility, were direct vassals of the King. They in turn would grant (parts of) their fiefdoms to lower-ranking tenants in a similar manner, thus continuing and broadening the line of power downwards.

For our purposes, the most interesting facet of this medieval system of government is the mutual interdependence it created between the King and nobility: the King largely depended on the fidelity of his tenants both for his income, which ultimately originated in the produce of the land, and for his military power-base, provided by the tenants. Conversely, the tenants depended on the King for their titles and estates which they de iure did not own. It is the result of this interdependence that the Curia Regis, in which the highest-ranking tenants were convened, must be understood not merely as an advisory body assisting the King at his will, but as an institution of its own right, quite central indeed to the feudal system.

The Anglo-Saxon states which existed prior to the Norman conquest bore little resemblance to the system established by William the Conqueror and his successors; in particular, they lacked the intricate feudal structure of the Norman state. Without the background of mutual interdependence between the king and his tenants, the Anglo-Saxon Witenagemot (Old English for 'meeting of wise men'; an advisory council to the Anglo-Saxon Kings made up of important noblemen and clergy) is unlikely to have played the same role as the Norman feudal council, which may well be the direct ancestor of Parliament. ${ }^{8}$

Still, it would amount to a great exaggeration to call the Curia Regis a parliament proper already. Wittke observes that ' $[\mathrm{t}]$ he central assembly of the Normans was a feudal assembly, with powers very vaguely defined, irregular in its meetings, and with all the characteristics of feudalism'. ${ }^{9}$ Undoubtedly, many features set the Norman assembly apart from what would be associated with the notion of Parliament today: ${ }^{10}$ the King was not legally required to seek the advice of the assembly, and not formally bound by such advice when he did.11 The assembly

8 The Curia Regis in early Norman times consisted of high-ranking nobility and clergymen only, while representatives of the counties, and finally of the boroughs, were added later. However, it was not until the reign of Edward III (1327-1377) that Parliament was divided into two Houses. Therefore, it would be incorrect to see only the House of Lords as a direct continuation of the Curia Regis since both originated in a joint early Parliament.

$9 \quad$ Wittke 1970 , p. 18.

10 In medieval and early modern times, the term had a different and vaguely defined meaning. It has been observed that in medieval England, the word 'parliament' hardly meant anything more than 'a meeting for speech or conference'. Cf. McIlwain 1910, p. 27.

11 However true this may be de iure, it was one of the characteristic realities of a feudal system that the King was dependant on his tenants, certainly in times of war where they provided for the King's army. It seems therefore to have been de facto impossible to ignore the advice of these tenants on important issues of state. 
was made up of feudal lords and leading clergymen, meeting irregularly upon the King's orders; it must by no means be understood as a body of popular or even democratic representation, neither of the people nor, and even less so, of the nation a concept entirely absent in that early period and for a long time to come. However, for our purposes the most revealing difference between this early version of Parliament and its modern successor lies in its mingling of functions. The Norman council and early Parliament acted as an executive body (in that its members, the feudal lords, executed decisions and orders in their domains). It also acted as a court of law which received petitions of subjects addressed to the King and dispensed justice in his name. At the same time, it acted as an advisory body to the King and passed legislation. In this sense, the Curia Regis performed tasks of all branches of government. It would, however, be misleading to say that the early Parliament performed all these functions in combination; rather, the severance of these powers as individual tasks was as yet unheard of and would have 'appeared anomalous'.12 Hence, while we are used - in Montesquieuvian tradition - to think of the making, application and interpretation of laws as separate tasks, it would be utterly anachronistic to apply such modern thinking to medieval England.

The development leap from Curia Regis to Parliament cannot easily be pinpointed to one specific point in time. However, the year 1215, in which the tenants-in-chief secured Magna Carta from the King, significantly limiting the power of the Monarch and strengthening their own, is often thought to be that moment. In any event, it is sufficient for us to note the existence of a direct ancestral relationship between the ancient Norman assembly and what eventually was to become Westminster Parliament.

Over time, all the separate institutions which today administer the legislative and judicial branches of government developed out of the ancient Curia. ${ }^{13}$ In the formation of government and the administration of executive tasks, feudal structures have ceased to play a role. Applying functional criteria, ${ }^{14}$ it is fair to say that the United Kingdom currently has an executive government (even though members of that government usually do hold a parliamentary mandate), an independent court system, and Parliament as a legislator, separate from the former two branches. However, despite this development, Parliament retained both legislative and judicial functions, even after this functional separation of powers had come into being, in that it continued as a 'Sovereign Law-making Court'15 in which 'The King in his Council in his Parliament' would give his answers - which can be characterised as judicial rulings and laws at the same time. Particularly in cases too difficult for the judges of the ordinary courts and in cases raising novel

Cf. Dicey 1860, p. 7.

With the exception of the King and the post-civil war Privy Council.

On the basis of a formal, institutional approach this statement would not hold true, at least with regard to the government. With regard to the judiciary, the recent establishment of the UK Supreme Court and the remodeling of the office of Lord Chancellor have substantially added to a formal separation of powers. Wittke 1970, p. 13. 
points of law, Parliament would give a ruling, in which it 'declare' the law, thus in effect making it.

This persistent lack of a clear dividing line between legislative and judicial functions of Parliament deserves particular attention in our context. Wittke notes that:

\begin{abstract}
Parliament, as a 'sovereign Law-making Court', 'legislated' and 'adjudicated', without any clear understanding as to when it was doing the one and when the other. Serious conflicts with the ordinary courts were therefore inevitable. They were all the more severe since both parties could claim jurisdiction because of their common descent from the old King's Council [the Curia Regis]. Both could cite precedents and history to support their claims. ${ }^{16}$
\end{abstract}

The fact that, in the Curia Regis, Parliament and the courts share a common ancestor, ${ }^{17}$ and that Parliament never formally abandoned its claim to being itself a court of law lies at the root of both the theoretical foundation of the doctrine of Parliamentary sovereignty and Parliament's claim to privilege. The rationale behind this is essentially the doctrine that lower courts cannot overrule judgments of higher courts, therefore they have no authority to invalidate or otherwise overrule statutory legislation (judgments of the High Court of Parliament). Hence, they may also not intrude into the rules made by this highest court for the regulation of its own affairs.

This is also the starting point of the long history of dispute between Parliament and the courts as to which institution has interpretative authority and jurisdiction in matters of privilege. It was held, accordingly, that '[i]n this common ancestry of Parliament, council, and courts [...] we have the key to many an otherwise confused situation, and the explanation of many a later struggle' ${ }^{18}$ The nature and cause of these struggles will be discussed in more detail further below, following the description of the historical development of privilege.

\title{
2.2. Historical Origins and Development of Privilege
}

While in the very early stages of parliamentary history only members of the nobility and clergy were summoned to Parliament, the so-called 'model Parliament' of 1295 also included two representatives of each county (knights of the shire) and each town or borough (burgesses). These classes of members came to sit as a separate chamber of Parliament, the House of Commons, ${ }^{19}$ from the year 1341.

Ibid.

17 This is not to say that all courts, or the structure of the UK court system, evolved directly out of the Curia Regis. However, until the UK Supreme Court took over this function of Parliament in 2009, the judicial powers of the King's Council survived in the House of Lords which, as the highest judicial authority superior to other courts, may be taken to represent 'the courts'.

18 McIlwain 1910

19 Note that the word 'Commons' refers to the counties and boroughs represented; members of the House of Commons are therefore accurately referred to as 'commoners', though this 
In discussing the historical development of parliamentary privilege, one has to distinguish between the House of Lords and the House of Commons from the point of their institutional separation onwards. While the Lords 'enjoy their privileges simply because of their immemorial role in Parliament as advisers of the Sovereign' ${ }^{20}$ those of the Commons evolved in a gradual and much more complex process. This is perhaps logical since the Commoners had not initially been part of the feudal chain of interdependences, each of whose members quite naturally enjoyed a certain degree of power and freedom vis-à-vis the other (though of course never quite uncontested).

In the discussion that follows, we will focus on the development of the privileges of the House of Commons which are also by far the most relevant ones from a comparative perspective. However, as a general rule, it should be borne in mind that the privileges enjoyed by the Commons can be assumed to accrue $a$ fortiori to the Lords. However, they have habitually played a much smaller role in the upper House, simply because the privileges of the Lords, as opposed to those of the Commons, have rarely been contested.

The individual privileges cannot always be seen as completely independent from each other and could more accurately be termed components of the overall privilege of Parliament. Their evolution did not follow entirely parallel lines throughout the process. Hence, the individual privileges of freedom of speech, freedom from arrest, freedom of access to the monarch, favourable construction, the privilege of the Commons to provide for the constitution of the House, and the penal jurisdiction of the Commons must be considered separately. ${ }^{21}$

It has been a custom of the House of Commons since very early in its history 22 to claim the privileges of the House from the King by means of a petition by the Speaker of the House to the King, presented at the commencement of every new Parliament, in which he asks the monarch to grant the House, in particular, 'freedom of speech in debate, freedom from arrest, freedom of access to His Majesty whenever occasion shall require; and that the most favourable construction should be placed upon all their proceedings' ${ }^{23}$ This practice is still maintained today, but merely as a formality. The petition is answered on behalf of the Queen by the Lord Chancellor - so commissioned by the monarch under letters patent - in a statement that 'Her Majesty most readily confirms all the rights and privileges which have ever been granted to or conferred upon the Commons, by Her Majesty or her royal predecessors' ${ }^{24}$ Historically, royal assent to privilege was not always given all that readily; centuries had to pass before the petition became but a ceremonial part of the opening session of a new Parliament.

word originally denotes everyone who is neither the monarch nor a peer, thus also including members of the nobility who do not hold a peerage.

Erskine May 2004, p. 77.

In treating the privileges in this order, I gladly follow the order of Erskine May's Treatise.

The exact time when such a petition was first made is not known, it may have been the Parliament of 1377 or 1406. Cf. Erskine May 2004, p. 78 et seq. and Wittke 1970, p. 21.

Erskine May 2004, p. 78.

Joint Committee on Parliamentary Privilege, First Report, 1999, HL 43-I, HC 214-I para. 6. 


\subsubsection{The Privilege of Freedom of Speech}

The privilege of freedom of speech in parliamentary debate has repeatedly been recognised as the single most important one in the range of privileges, since it is not doubted that without the opportunity for members of parliament to speak their minds freely, they would not be able to discharge their function properly, and so the very purpose of a parliament would be undermined. ${ }^{25}$ In the UK, freedom of speech is today seen as 'inherent in the constitution of Parliament'. ${ }^{26}$

Until the late $15^{\text {th }}$ century, however, the Commons's right to free speech seems to have existed in a vague, undefined way, 'as a matter of tradition rather than by virtue of a privilege sought and obtained' ${ }^{27}$ Prior to that time, the House tried to secure for itself a degree of freedom by petitioning the monarch for 'permission to correct any inadvertent misrepresentations of the House's view to the King' ${ }^{28}$ and asked that, where the House or Speaker should displease the King or infringe his prerogative, this should be regarded as unintentional. ${ }^{29}$ The earliest case hinting at the existence of the privilege was possibly that of Sir Thomas Haxey. ${ }^{30}$ Haxey was not a member of Parliament, but criticised King Richard II in a petition to the Commons, and was subsequently sentenced to death for treason by the House of Lords. However, he was later rehabilitated under Henry IV and the Commons declared that the action against him was against 'les libertesde lez ditz Communes'. ${ }^{31}$

According to Erskine May, the first distinct claim to the privilege of freedom of speech was made by Speaker Sir Thomas More in 1523, and by the end of the $16^{\text {th }}$ century the inclusion of freedom of speech in the Speaker's petition had become regular, justifying the privilege as 'part of the old ancient order'. ${ }^{32}$ This does not mean, however, that the privilege was always granted or treated as unequivocal by the King, and by the House itself. Erskine May notes that '[the House] was frequently ready to take punitive action [...] against those [members] who overstepped the mark in debate'.$^{33}$ Equally, the Crown was not entirely ready yet to accept unlimited freedom of speech:

This is a general observation valid for all parliaments. Cf. Van der Hulst 2000, p. 63.

Hood Phillips et al. 2001, p. 272.

Erskine May 2004, p. 79 and Hood Phillips et al. 2001, p. 273.

Claim by Speaker Cheney in 1399, 3 Rot. Parl. 424, 425.

Erskine May 2004, p. 79.

(1396-97) Rot. Parl. iii, 434.

See Barnett 2009, p. 430; Erskine May 2004, p. 79.

Erskine May 2004, p. 80.

Ibid. 
Her Majesty granteth you liberal but not licentious speech, liberty therefore but with due limitation... To say yea or no to bills, God forbid that any man should be restrained or afraid to answer according to his best liking... which is the very true liberty of the House; not, as some suppose, to speak there of all causes as him listeth... No King fit for his state will suffer such absurdities. ${ }^{34}$

Yet, several instances during the reign of Elizabeth I exemplify the growing confidence of the House of Commons vis-à-vis the monarch on the freedom of speech. In 1566 the Queen was offended by debates in both Houses regarding matters of her succession and forbade further discussion in Parliament, summoning several Lords and the Speaker of the Commons. This was regarded as an infringement of privilege and the royal command was ignored. The Queen yielded and 'revoke[d] her former commandments; but desired the House to proceed no further in the matter at that time'. ${ }^{35}$ Similarly, the Queen backed down when the Commons protested breach of privilege after one of the House's members, Strickland, had been called before the Queen's Council (the Privy Council) and thus was prevented from attending parliament 'for having moved to reform the Common Prayer Book'. ${ }^{36}$ Though the Crown contended that Strickland had not been detained for his speech but for introducing a bill in breach of the royal prerogative, the Commons could not be satisfied 'by such quibbling' and continued to clamour for their privileges. Though the member was released, the Queen continued to prevent the Commons from addressing certain matters, especially those related to religious affairs.

Between Elizabeth's reign (1558-1603) and the English civil war of 1642-1651, the House of Commons continued to struggle for complete freedom of speech, especially against King Charles I, who once ordered the arrest of Sir John Elliot and two other members of the Commons - Holles and Valentine - 'for seditious words spoken in debate and for violence against the Speaker, who had been physically restrained in the Chair in order to delay the adjournment of the House'. ${ }^{37}$ The members were sentenced in the Court of King's Bench under the argument that 'privilege did not extend to seditious comments in the Chamber and that King's Bench could properly take notice of day-to-day events in the High Court of Parliament, such as the assault of the Speaker'. ${ }^{38}$ Upon the re-establishment of Parliament following the eleven-year personal rule of Charles I, the House of Lords reversed the judgment against the three members in 1668 under a writ of error and declared their arrests illegal and contrary to privilege. R. v. Elliot, Hollis and Valentine was the last example of the Crown taking judicial action against words spoken in Parliament. ${ }^{39}$

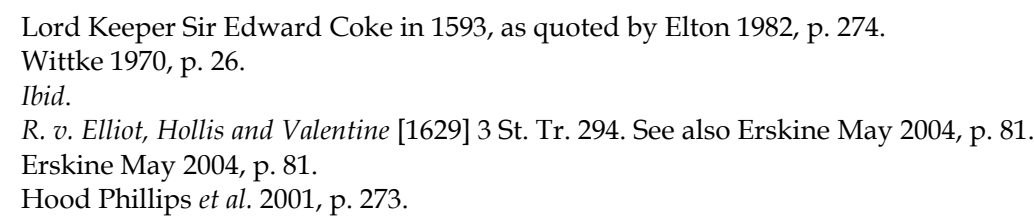


Freedom of speech in debate has first been recognised in statutory form in section VI of the Treason and Seditious Practices Act $1661^{40}$ which provided that the other provisions of this Act should not deny members of either House their 'freedom and privilege in debating any matters or business which shall be propounded or debated'. The fullest form of statutory recognition of freedom of speech to this date was achieved by the Bill of Rights 1689, in which the

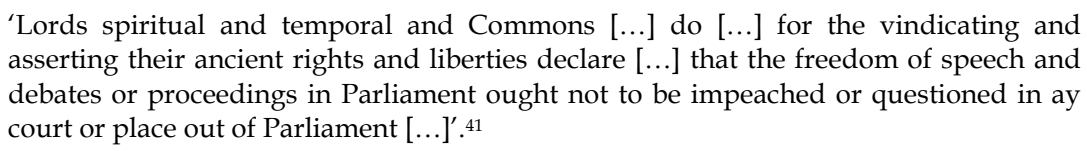

Article 9 of the Bill of Rights is still the most important statutory provision with regard to the privilege of freedom of speech and debate. The privilege as such has remained unchallenged as an institution since its enactment, and Article 9 is still in force. However, there have been minor implied amendments by statute. Controversies have, at times, occurred as to the means, and especially the competent authority, of its enforcement and interpretation. These issues will be dealt with in detail further below.

\subsubsection{The Privilege of Freedom from Arrest and Molestation}

The historical development of the privilege of freedom from arrest and molestation is not entirely congruent with that of other privileges, although its application has often been closely linked with them, since arrest was often the consequence of a failed assertion of another privilege, for example, freedom of speech.

It is known that the principle that members of Parliament should not be arrested or molested was established relatively early in history. As part of the King's peace, ${ }^{42}$ it served to '[ensure] the attendance of members of the [King's] Council, judicial and other public officers, and members of the royal household ${ }^{43}$ and was understood as an instrument designed to 'protect the right of the King to the services of his advisers' ${ }^{44}$ In earlier times, the rationale behind the privilege of freedom from arrest and molestation was thus that servants of the monarch must not be disturbed in doing their duty, as that would have meant an infringement of the rights of the monarch himself.

After the emergence of Parliament out of the Curia Regis, freedom from arrest remained, in theory, a matter of course, while it was later also included in the

401661 c1 13 Char. 2 Stat. 1: An Act for Safety and Preservation of His Majesties Person and Government against Treasonable and Seditious practices and attempts. The Act was partially repealed and altered by the Statute Law Revision Acts 1863, 1888 and 1948 and finally completely repealed by the Criminal Law Act 1967.

$41 \quad 1688$ c2 1 Will. \& Mar. 2: Bill of Rights (An Act Declaring the Rights and Liberties of the Subject and Settling the Succession of the Crown), Art. 9.

42 Pax regis, the guarantee of the monarch to peace and security to all subjects of the law.

$43 \quad$ Hood Phillips et al. 2001, p. 270.

$44 \quad$ Barnett 2009, p. 429. 
Speaker's petition mentioned earlier. It was historically of great importance to the functioning of Parliament, since the possibility of arrest in civil matters, such as for the enforcement of a fine, or to secure a person's appearance before court, could have seriously undermined Parliament's functioning, which required the attendance of its members. ${ }^{45}$ This may be seen as early evidence for the established principle that privilege does not exist for the convenience of members but for the corporate interest of Parliament. Further, freedom from arrest may also reflect the logic of Parliament as the highest court of the realm, whose members should not be accountable to a lower court. Even in 1340, a member was released from prison, though with considerable delay, following an assertion of freedom from arrest. ${ }^{46}$

According to Erskine May, the House of Commons claimed privilege from arrest 'for debt, contract, or trespass of any kind, according to the custom of the realm' in the early $15^{\text {th }}$ century. The same privilege was claimed for servants of members in 1404, following the case of Richard Cheddar. ${ }^{47}$ A servant of a member of the Commons, Cheddar, had been subjected to 'orible baterie et mal-fait' 48 on his way to Parliament. The Commons thereupon petitioned the King to have the attacker pay double damages in addition to a fine to the King. The penalty was imposed accordingly and later became the standard penalty for molestation of members and their servants. ${ }^{49}$

Whereas the privilege of freedom from arrest seems to have been recognised early on, its application, according to Erskine May, has been 'patchy and often beyond the power of the Commons alone to enforce'..$^{50}$ This is shown, along with other examples, by the case of the Speaker of the Commons Thorpe. ${ }^{51}$ In 1452, Thorpe was imprisoned by order of the House of Lords, contrary to the advice of judges who pointed out that this would amount to a violation of privilege. His release, upon the request of the Commons, was denied despite claims to privilege. At the time, the Commons had to accept Thorpe's imprisonment and elected a new Speaker.

While the existence of a customary privilege of freedom from arrest was altogether denied at several points by the courts, but nonetheless by and large accepted as being 'deeply engrained', 52 Parliament soon accepted its limitation to civil cases. By resolution of the House of Commons it was declared in 1675 that privilege should apply 'in all cases except treason, felony and breach of the peace' and, in 1697, that it should not apply in cases of 'forcible entries or forcible necessary for the proper functioning of Parliament was never much at issue as a justification of parliamentary privilege, as the High Court of Parliament was assumed to have a right to the attendance of its members.

Erskine May 2004, p. 83.

Rot. Parl. 3 541-42.

Erskine May 2004, p. 83, note 3.

Wittke 1970, p. 33.

Erskine May 2004, p. 83.

Rot. Parl. 5 239-40.

Erskine May 2004, p. 83. 
detainers'. ${ }^{53}$ In the case of John Wilke, ${ }^{54}$ both Houses jointly resolved that the privilege should also not apply to the writing and publication of seditious libel. From the mid-18 th century onward it was an established principle that freedom of arrest should not apply to any indictable offence. ${ }^{55}$

Erskine May notes that originally the privilege even exceeded freedom from arrest, preventing members from being impleaded, that is, sued (which might have resulted in an obligation to attend Court and thus a failure to attend Parliament). Thus, no civil action could be brought against them at all upon which they might have been arrested or otherwise prevented from attending Parliament. However, instances can be found in which members waived their privilege upon petitions from the parties to a dispute in order for suits to be able to proceed. ${ }^{56}$

In 1770, with the enactment of the Parliamentary Privilege Act ${ }^{57}$ of that year, such practice was brought to an end with the effect that civil suits could be brought against members at any time, but which, however, further secured their freedom from arrest. As a result, any legal means could be employed to coerce a member of Parliament, with the exception of attachment of his body.

The privilege of freedom from arrest was finally effectively marginalised (at least as regards cases of arrest proper) with the enactment of the Judgments Act 1838,58 which abolished imprisonment in civil cases and with the enactment of the Debtors Act $1869^{59}$ by which imprisonment specifically for debt was abolished. Since the privilege is not strictly limited to arrest proper, but also prohibits other actions by which members could be prevented from attending Parliament (such as an obligation to appear in Court as a witness), the privilege is, however, not wholly obsolete. Its modern application will be dealt with further below. It must be noted, however, that the role of this privilege is today largely regarded as very limited and Committee reports have repeatedly recommended its complete abolition. ${ }^{60}$

\subsubsection{The Privilege of Access to Her Majesty}

Since medieval times, the Speaker of the House of Commons included the privilege of access to the monarch in his traditional petition for privileges. The privilege of access does not accrue to individual members of the Commons but to the House as a body, usually exercised by the Speaker. ${ }^{61}$ This is in line with the long-standing customary principle that the monarch may not, even as a spectator, be present in the

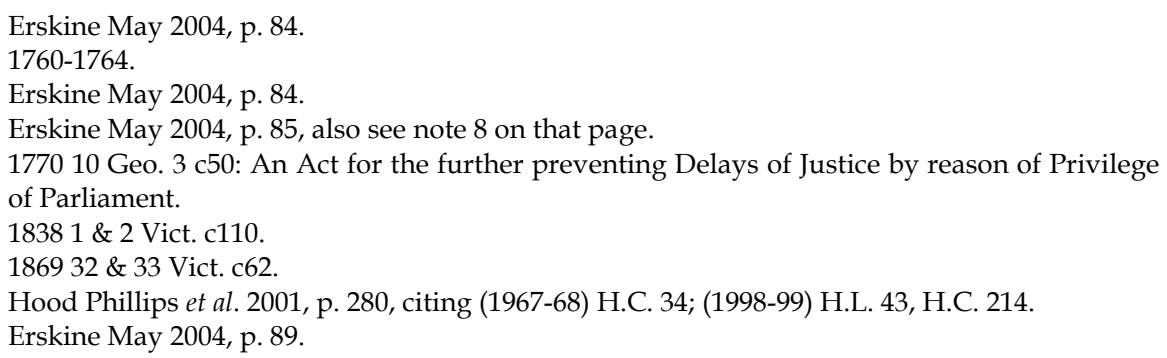


House during debates or take notice of pending matters or individual speeches by members. ${ }^{62}$

A different privilege of access applies to the Lords. The monarch may freely attend debates in the House, and individual Lords (theoretically) enjoy access to him or her by virtue of the privilege of peerage. ${ }^{63}$

\subsubsection{The Privilege of Favourable Construction}

Traditionally, the Speaker of the Commons also included in his petition to the monarch the request to apply to all the House's proceedings the 'most favourable construction', so that misrepresentations of such proceedings, made especially by the Speaker to the monarch, should be regarded as unintentional.

Mainly due to the continuous and largely uncontested application of the privilege of freedom of speech and debate, the importance of the privilege of favourable construction must be regarded as less than marginal. It has been so for a long time, as in any case the monarch is not allowed to take notice of proceedings in Parliament otherwise than by being notified of the House's decision. Neither is the Crown - read: the government - entitled to take any action with regard to proceedings in Parliament. In effect, the acceptance of freedom of speech has rendered favourable construction obsolete.

\subsubsection{The Privilege of the House of Commons to Provide for its own Constitution}

Though materially quite remote from the subject of immunity, the privilege of the Commons to provide for its own constitution as prescribed by law, namely, to set and enforce the rules governing its own membership and procedure, must be regarded as supremely important to the independence of the House from interference by the Crown. Without the ability to determine its own constitution, including the regulation of elections and the resolution of disputes as to this matter, the House would have remained substantially dependent on the Crown (very possibly through the Courts) and on the House of Lords. ${ }^{64}$

The development of this privilege began in the $16^{\text {th }}$ century. Whereas first minor individual powers were granted to the Speaker and House, ${ }^{65}$ the House, or the Committee of Privileges, took full responsibility for the scrutiny of elections in

62 Established after an incident in 1642 during which King Charles I entered the House of Commons with an armed party in order to arrest five members for treason. While the arrest failed as the members in question were not present, Charles' intrusion was later considered to have been a breach of privilege.

63 For a short discussion of the privilege of peerage, see below.

64 As far as elections are regulated by statute, royal assent is of course required. Therefore it might seem as though the power to regulate elections by statute does not add much to the independence of the Commons from the Crown. It should be borne in mind, however, that royal assent to acts of Parliament is never withheld as a matter of constitutional convention.

65 E.g. in 1515, the Speaker was authorised by the King to grant permission to members to leave Parliament before the end of the session. Cf. Erskine May 2004, p. 90 et seq. 
1593.66 The right of the Commons to decide in cases of disputed elections was confirmed in the case of Goodwin v. Fortescue in $1604,{ }^{67}$ when the House of Commons prevailed in a dispute with the Crown, which had contested the election of Sir Francis Goodwin because he was an outlaw.

Jurisdiction of the House of Commons for questions concerning elections for this House was confirmed by statute in 1695 with the enactment of the Parliamentary Elections Act. ${ }^{68}$ It was delegated to the courts in 1868, although jurisdiction in cases not provided for by statute were retained. Cases in which the House is still exclusively competent involve the filling of casual vacancies, ${ }^{69}$ the determination of legal disqualification of members otherwise properly elected,70 and the expulsion of members unfit to serve. ${ }^{71}$ Since the enactment of the Parliamentary Elections Act 1868, ${ }^{72}$ as amended by the Representation of the People Act 1983, the determination of disputed elections is only nominally in the hands of the House of Commons. In practice, the Commons give effect to the rulings of election courts. ${ }^{73}$

The privilege of the Commons to provide for its own constitution must be seen in the wider context of all other privileges, which would be substantially weakened in its absence; for was it not for the House itself to determine, for instance, whether a member is fit to serve, this would create a potentially very critical loophole for the then competent Crown or courts to circumvent, for example, where freedom of speech is concerned.

\subsubsection{The Principle of Exclusive Cognisance}

All individual privileges can be seen as emanations of the wider principle that 'what happens in Parliament is controlled by Parliament'. ${ }^{74}$ This foundation of

$66 \quad$ Erskine May 2004, p. 90.

672 State Tr. 91

$68 \quad 16957$ \& 8 Will. 3 c25: An Act for the further regulating Elections of members to serve in Parliament and for the preventing irregular Proceedings of Sheriffs and other Officers in the electing and returning such members.

69 This is done by means of a warrant from the Speaker, for the issue of a writ for a by-election to fill that specific vacancy. Cf. Hood Phillips et al. 2001, p. 281.

70 In which case the member is not admitted or, if she already took her seat, expelled. Hood Phillips et al. 2001, p. 281.

In the absence of a legal ground for disqualification. Cf. Hood Phillips et al. 2001, p. 281.

186831 \& 32 Vict. 125

Hood Phillips et al. 2001, p. 281. The procedure for questioning parliamentary election results is laid down in Part III, Sections 120-126 of the Representation of the People Act 1983 (c2). Election results may be challenged by means of a petition to the High Court, presented within 21 days of the election of the member to whom the petition relates. The petition is then tried by an election court. This court is not a permanent institution but is set up when the need arises. It comprises two judges of the High Court rota. There is no appeal against an election court ruling.

$74 \quad$ Hood Phillips et al. 2001, p. 281. 
parliamentary privilege is known as the principle of exclusive cognisance. ${ }^{75}$ It follows from this principle that the internal affairs of Parliament may not be reviewed by any other institution, body, or person but fall under the exclusive jurisdiction of the two Houses. ${ }^{76}$ Exclusive cognisance therefore includes the privilege of Article 9 of the Bill of Rights 1689, but it is wider than that. How much wider will be the subject of a more detailed discussion below.

The doctrinal foundation of exclusive cognisance has historically been the notion of Parliament as a court. In the words of Lord Coke:

\begin{abstract}
And as every Court of justice hath laws and customs for its direction, some by the common law, some by the civill and canon law, some by peculiar lawes and customes, \&c. So the High Court of Parliament suis propriis legibus et consuetudinibus subsistit. It is lex et consuetudo parliamenti, that all weighty matters in any parliament moved concerning the peers of the realm, or commons in parliament assembled, ought to be determined, adjudged, and discussed by the course of the parliament, and not by the civill law, nor yet by the common law of this realm used in more inferior courts. ${ }^{77}$ [emphasis added]
\end{abstract}

Accordingly, the principle of exclusive cognisance lies at the basis of the notion of the law of Parliament as a separate legal system, and hence of Parliament as a place or entity which lies outside the realm of the law of the land.

Throughout parliamentary history, exclusive cognisance has provoked the question of what exactly must be considered an 'internal affair'. Does exclusive cognisance only relate to the inherent constitutional tasks of Parliament and matters directly connected to these tasks? This would mean that everything relating to the legislative process and also, for instance, issues concerning membership of either House would be off-limits for the ordinary courts. Or does exclusive cognisance extend to anything that happens in Parliament, including matters such as the employment of administrative staff, working conditions in parliamentary offices or even contracts concerning the supply of catering and stationery?

Historically, the courts have consistently declined jurisdiction in matters which manifestly touched the core activities of Parliament: its constitutional functions. One example thereof is the case of Bradlaugh v. Gossett $t^{78}$ of 1884, in which the High Court was not ready to interfere with the decision of the House not to allow Bradlaugh to take the parliamentary oath because he was an atheist. However, exclusive cognisance also led to more contentious decisions, sometimes to the effect that statutory legislation made by Parliament was not applied to (bodies of) Parliament, even in cases which did not - or only in the widest sense - relate to the core business of Parliament. This was the case in $R v$. Graham-Campbell ex parte

75 Joint Committee on Parliamentary Privilege, minutes of evidence to the first report, 1999, Memorandum submitted by the Clerk of the House of Commons, para. 18 et seq.

76 See section 3.1 of this chapter for a discussion of this principle with respect to independent review commissions.

77 Coke 1797, p. 14

$78 \quad$ Bradlaugh v. Gossett (1884) 12 QBD 271. 
Herbert, ${ }^{79}$ where the refusal of the Chief Metropolitan Magistrate to try, among others, alleged breaches of the Licensing Act by the House of Commons' kitchen committee was upheld by the Divisional Court. One of the issues in GrahamCampbell was the sale of 'intoxicating liquor' at the House of Commons' bar without a licence, as otherwise required by the Licensing Act. In declining jurisdiction, the Court reasoned that, were the Court to assume jurisdiction in such matters, this 'might conceivably be, after the various stages of [...] proceedings had been passed, to make the House of Lords the arbiter of the House of Commons' ${ }^{80}$ Chafetz notes that this view was, at the time of Graham-Campbell, outdated and a mere leftover from times when the Commons still had to guard its privileges with much anxiety: '[a]fter all, the fact that the House of Lords might be the final judge of the legality of the House of Commons' refreshment operations hardly bespeaks great power on the Lords' part to interfere in the legislative workings of the Commons' ${ }^{81}$

Thus, a given case either does or does not fall within Parliament's exclusive cognisance, depending on whether a functional link is required between that case and the core tasks of Parliament. The question whether such a functional criterion exists lies at the heart of the relationship between the law of Parliament and the law of the land - the relationship between Parliament and the courts - which has at times been fraught with conflict. A final solution to the border conflict between the area in which Parliament enjoys exclusive cognisance and that in which the ordinary courts exercise jurisdiction according to the law of the land has not yet been found. It is possible that such a final solution could only be brought about by statutory regulation. Nevertheless, case law and a modernised self-image of Parliament have led to a good approximation of the limits of exclusive cognisance. We will explore these limits at length in our discussion of the relationship between lex parliament and lex terrae further below.

One important peculiarity of exclusive cognisance, as opposed to other, more specific privileges like freedom of speech and debate, is that it can be waived or relinquished by Parliament. In other words, the Parliament may explicitly allow the courts to refer to certain materials or to try cases which would otherwise fall within the range of exclusive cognisance. For instance, in 1980 Parliament resolved to allow certain parliamentary papers, which were subject to exclusive cognisance, to be used in court. ${ }^{82}$ More generally, Parliament has never claimed exclusive cognisance of 'ordinary crimes' (crimes unrelated to proceedings in Parliament, such as theft, sexual assault, and so on) committed in Parliament. Such a waiver is only possible, however, where specific privileges - usually Article 9 of the Bill of Rights - do not apply.

R v. Graham-Campbell ex parte Herbert (1935) 1 KB 594.

Ibid., at 602.

Chafetz 2007, p. 41

Erskine May 2004, p. 105. 


\subsection{The House of Lords and the Privileges of the Commons}

The above overview of the varied history of parliamentary privilege, though very concise, has shown that the legal structure of parliamentary privilege has historically grown alongside the institutions, which today are to a large extent divided along the lines which separate the executive, legislative, and judicial branches of government. However, it has also been shown that these institutions share a common ancestry in the Curia Regis. Certainly, Britain's institutional and legal history has seen a variety of decisive events. However, there has never been an incisive 'constitutional moment' to conclusively clarify inter-institutional relations between the different organs which have developed from the ancient Curia. The fact that, historically, the different branches of government had once been a single body, auxiliary to the monarch, is still reflected in what might be called an overlap or a grey area in powers and competences between the two Houses of Parliament, the courts, and the Crown. Such overlap has long existed, and in part still exists, especially between the legislative and judicial branches of government: until recently the House of Lords still performed tasks of supreme appellate jurisdiction in civil cases originating from the ordinary courts of law ${ }^{83}$ and both Houses retain certain judicial powers with regard to their own privileges, and, in the case of the House of Commons, with regard to elections. ${ }^{84}$

With regard to parliamentary privilege, the legal relationships between the House of Commons, the House of Lords and the courts have for a long time been very complicated and utterly vague. ${ }^{85}$ It is therefore not surprising that the history of privilege is riddled with clashes between these institutions. ${ }^{86}$ This is mainly due to two factors.

On the one hand there was, as Wittke puts it, 'an absolute lack of understanding that existed for so long a time in regard of the judicial functions and powers of Parliament'. ${ }^{87}$ This confusion or controversy which existed on the question of which of the Houses should have supreme jurisdiction could not easily be resolved, as the House of Lords could lay a just claim to their direct descent (and, in its view, a more direct descent than that of the Commons, though this may be doubted) from the old Norman Council, reserving supreme judicial powers for itself. However, a clear definition of what these powers actually were had never been rendered, because in ancient times the concept of different and separate kinds of powers did not exist, as has been argued above. Conversely, the House of Commons could with the same right claim to be a constituent part of the High Court of Parliament. And at least in theory the highest court in the realm is a

83 Of course this is only correct from a strictly institutional point of view. De facto, since the enactment of the Appellate Jurisdiction Act 1876, only the Law Lords exercised the judicial tasks of the House. As of October 2009, the new UK Supreme Court, instituted by Part III of the Constitutional Reform Act 2005, has taken over these judicial functions.

$84 \quad$ See section 2.2.5 above.

$85 \quad$ Wittke 1970, p. 39.

86 Cf. Chafetz 2007, introduction.

$87 \quad$ Wittke 1970, p. 75. 
singular body at the very top of the legislative and judicial system. Accordingly, there was no precedent to show a hierarchical inferiority of the Commons to the Lords; certainly not concerning jurisdiction in matters of privilege, which itself constitutes a part of the lex et consuetudo parliamenti, the law of parliament. Lastly, the courts (with the House of Lords at the top of their hierarchical structure) were also able to produce precedents to uphold their claim to a direct descent from the old Curia Regis. While legislative power very soon lay firmly in the hands of Parliament, this was not so readily accepted for jurisdiction in cases involving parliamentary privilege which raised difficult questions as to the position of privilege: does that position lie within or outside the legal system of which the Lords were the final arbiter? And if it lies outside of that legal system, does that separation settle the question of jurisdiction? Today's greatest authority on this question, Erskine May's Treatise, does not seem to give an all too satisfactory answer, even though it does clearly side with those who see the position of privilege within the ordinary legal system: ' [...] privilege, though part of the law of the land, is to a certain extent an exemption from the general law' ${ }^{\prime}{ }^{8}$

The other factor responsible for the complications occurring between the two Houses and the courts respectively, and especially for disputes over jurisdiction, was of a more practical and political, and less of a doctrinal nature. All three institutions had reason to guard their powers jealously vis-à-vis the others. This was especially true for the House of Commons in late medieval times, when it had not yet entirely secured its position in the power continuum of the realm, and had to fear interference and the curtailing of its powers by the Crown. It was particularly important for the Commons not only to be able to obtain (and later to uphold the customary nature of) its privileges from the monarch, but also to retain jurisdiction over privilege for itself, as the already established course of appellate jurisdiction would evidently have meant that 'to allow the courts to pass on questions of privilege, was to submit those privileges to the final arbitrament of the House of Lords' ${ }^{89}$ Owing to the greater allegiance of the Lords to the Crown, and to the natural tendency of the upper House to guard its own superiority, applying the ordinary line of appeal to matters of privilege would have jeopardised the independence of the Commons.

Historical instances of conflict between the Commons and Lords regarding privilege are abundant; they most often revolve around the abovementioned questions of jurisdiction, as illustrated by the following examples. In the early $17^{\text {th }}$ century, the Commons summoned one Edward Floyd to the bar of the House and tried him for slanderous remarks about the Elector Palatine Charles III Philip, sonin-law of King James I. Floyd was not a member of the Commons, nor in any way engaged with the affairs of the House, yet it assumed jurisdiction and 'inflicted [...] punishment of the most cruel and humiliating nature' on him..$^{90}$ The Lords were infuriated by this assumption of jurisdiction, jealous of their own judicial powers, 
and demanded precedents for the course of actions of the Commons. In Floyd's case, the Commons yielded and left Floyd to the jurisdiction of the Lords, where he was 'once more cruelly punished'. ${ }^{91}$

In the famous and noted case of Skinner and the East India Company, Skinner, who had lost certain possessions (including ships and an island) to plundering agents of the company, petitioned the King for redress which he believed unobtainable in an ordinary court. The King first referred the case to be arbitrated in the Privy Council; however, settlement could not be achieved at a sum acceptable to Skinner. Thereupon the King asked the House of Lords to deliver justice. Before the procedure in the Lords could come to a close, the Company had petitioned the Commons (several of the Company's members in fact happened to also be members of the Commons), alleging irregularities in the procedure before the Lords. The Upper House subsequently ordered the Company to pay Skinner £5,000, despite resolutions issued by the Lower House, stating breach of privilege of several of its members. Adopting the position that it was beyond the powers of the Lords to assume first instance jurisdiction in cases not involving Peers or the business of the House itself, the Commons resolved that anybody who helped to execute the Lords's judgment should be regarded in breach of the privileges of the Commons. The Lords, however, fined the deputy-governor of the Company for petitioning the Commons and thereby infringing the privilege of the Lords. After some further quarrels, involving the 'mysterious' relief of the deputy-governor of his fine and two rejected bills for the privileges of the Commons to be limited, and, conversely, for the Lords to revoke their 'illegal' judgment, the King ordered the dispute to end and all records of the struggle to be erased. This order was obeyed by both Houses. The record book of the Commons shows only the King's order to delete, and the Lords' record is a blank space. The question as to the right of the Lords to take notice of cases in first instance remained, for the time being, unresolved. ${ }^{92}$

These, and several other cases, illustrate the jealousy with which both Houses tried to secure their powers and their privilege, but also the confusion that existed as to how these powers and privileges must be defined. A discussion of the judicial and penal powers of Parliament in modern times, and their relationship with privilege, follows further below.

\section{Demarcating Exclusive Cognisance: Lex Parliamenti and Lex Terrae}

One of the most central questions arising in the context of a conceptual analysis of British parliamentary privilege is that of the nature of the relationship between lex et consuetudo parliamenti (hereinafter lex parliamenti) and lex terrae. Lex parliamenti is the law which governs the internal affairs of Parliament and of which only Parliament may take cognisance, and lex terrae is the law of the land - statutory and common law, as well as equity.

Ibid.

For a full account of this case, see Wittke 1970, p. 79 et seq. 
The relationship between lex parliamenti and lex terrae, or rather the question what that relationship should ideally be, is the focal point where the doctrinal issues of parliamentary privilege and parliamentary sovereignty meet the more practical question of how justice is best done for an effective, independent legislature and the citizens. The latter is the question which all systems of parliamentary immunity have to answer: the immunity dilemma. The UK has never adopted conclusive constitutional rules to demarcate lex parliamenti from lex terrae, and has instead opted for constitutional uncertainty - or flexibility. In the following, we will examine the relationship between the law of Parliament and the law of the land and the effect of that relationship on parliamentary privilege.

\subsection{A Categorisation}

As much as many historical institutional quarrels have been resolved, or are by now of merely academic interest, the particular problem of doing equal justice to potentially antagonistic needs is very much alive. As has been shown in the previous part, this is particularly true for the British system of privilege. The historical notion that Parliament, as the highest court of the land, enjoys exclusive cognisance of its internal affairs has never really been abandoned, and the constitution does not provide for sufficiently clear boundaries between institutions and the powers allocated to them.

The highly abstract discussion of whether or not the part of the law of which Parliament enjoys exclusive cognisance must be regarded as a full-fledged separate legal system (or, if this is answered in the negative, what it is instead) may at first glance be of no practical relevance. However, in practice the relationship between lex parliamenti and lex terrae materialises as the relationship between institutions, defined by the distribution of powers concerning the law of parliament between the two Houses of Parliament and the courts. The relevant powers can roughly be classified as follows:

a. the power to determine the extent, that is to say, the limits, of lex parliamenti, and

b. the power to determine the interpretation and application of its content.

Hence, with regard to the privileges of Parliament, the relationship between lex parliamenti and lex terrae boils down to a question of jurisdiction: who has the delimitative authority to determine the extent of privilege; within the reach of privilege, who has the interpretative authority to determine the content and meaning thereof?

Admittedly these two powers are not as clearly distinct from one another as the above categorisation might suggest. The question (long resolved, though, by the Parliamentary Papers Act 1840) of whether publications done by order of Parliament should be privileged and therefore immune from, for example, defamation suits may serve as an example. Whether the nature of such a publication is that of a privileged parliamentary proceeding (whether it falls under Article 9 of the Bill of Rights 1689) is clearly an interpretative question with regard to the meaning of 'proceedings'. Viewed from a different angle, however, the question 
whether the act of publishing, done by a private person or company unconnected to Parliament, is governed by the law of the land or the law pertaining to internal affairs of Parliament only, certainly is a delimitative one. The powers of interpretation and delimitation cannot fully be separated from one another.

To a certain extent this problem is moot, as Parliament is the supreme legislator of the law of the land and the law of Parliament. It has the power to determine, to define, and to demarcate privilege by enacting statutory legislation to that effect. The issue of jurisdiction discussed in this section therefore arises only where a sufficiently clear definition of either the content or the extent (or both) of parliamentary privilege is lacking. However, bearing in mind that statutory instruments with regard to privilege are as scarce as they are ancient, it is evident that this situation is bound to arise regularly. When it does, it is for the courts (and for Parliament where it sees the necessity) to speak out on which powers each institution possesses, respectively. Even though a clear separation of interpretation and demarcation is hardly possible, case law has shown that both institutions do themselves see a difference between the two powers and deal with them accordingly.

Chafetz proposes that, applied to British Parliament and courts, three theoretical possibilities exist for the relationship between lex parliamenti and lex terrae, and thereby for the question of jurisdiction in matters of privilege, namely:

(1) the courts have no say whatsoever in lex parliamenti and both powers are fully exercised by Parliament. Parliament defines the legal nature and the content of privilege. In addition, it has exclusive jurisdiction to decide whether or not a certain matter involves privilege, that is, whether that matter comes within the sphere of its application.

(2) the courts can adjudicate on the extent but not on the interpretation and application of lex parliamenti. Parliament has the sole power to define the nature and content of privilege. The courts retain jurisdiction to determine whether or not privilege is at issue in a case before them.

(3) the courts are competent to exercise both powers, namely, to review the extent and the interpretation and application of the lex parliamenti. The courts fully treat privilege as part of the law of the land: they have the power to define the nature and content of privilege and they also have jurisdiction to decide whether privilege is at issue in a certain case. ${ }^{93}$

Which of these possibilities should be adopted depends on the particular legal and political situation of a system. It can be argued that, where Parliament as the democratically legitimised legislator must be anxious to secure its power and position against intrusions by the executive, lex parliamenti should, in case of conflict between the two, enjoy primacy over lex terrae. Applied to British parliamentary history, Chafetz calls this the 'Blackstonian conception of privilege', 94 after the

Chafetz 2007, p. 27

94 Chafetz 2007, p. 28 et seq. 
famous judge and jurist who, at a time where the Commons still were not entirely safe in their position vis-à-vis the Crown and Lords, emphasised the importance of the absolute protection of the Commons which necessitated the lower House to have both powers in its own hands:

[...] whatever matter arises concerning either house of parliament, ought to be examined, discussed, and adjudged in that house to which it relates, and not elsewhere. ${ }^{95}$

On the other hand, it can - and must - of course be argued that this absolute supremacy of lex parliamenti over lex terrae can work to the extreme detriment of the citizens in that there would be absolutely no legal remedy for the ordinary citizen against an unfavourable decision of Parliament. Accordingly, it might carry benefits, in particular for citizens vis-à-vis Parliament, to define the abovementioned relationship with a strong tilt towards the primacy of lex terrae so that the courts would be competent to take cognisance of, and exercise full jurisdiction in cases involving lex parliamenti. As a consequence thereof, the law of Parliament could then well be regarded as part of the lex terrae, with no room for exclusive cognisance. The obvious danger here is, of course, that Parliament would no longer be able to effectively shield itself from influence by citizens or politically or otherwise biased courts. Therefore, the third option described above leaves Parliament without much protection against an intrusive executive and judiciary. From a point of view favouring the separation of powers and inter-institutional checks and balances, this option would therefore not be acceptable.

From our modern vantage point it seems prima facie most logical to adopt the second of the options set out above. It will be shown in the following that the second option is indeed the most suitable one of the three to describe the current situation, even though recent case law has shown a tendency to limit exclusive cognisance more and more. In any event, the nuances of a long line of individual judicial decisions and legislative acts were what have led to the intricate construction with which we are faced today when looking at the relationship between the parliamentary law of privilege and the law of the land.

\subsection{The Evolution of the Relationship between Lex Parliamenti and Lex Terrae in Case Law}

The long history of British parliamentary privilege reflects a slow movement from the 'Blackstonian' model to what Chafetz calls the 'Millian' 96 paradigm. Whereas in medieval times strong privileges appeared necessary to defend Parliament, especially the Commons, against the monarch (and his power vested in the common law courts and the House of Lords), the Commons later became

Blackstone 1832, p. 119

96 After J.S. Mill, who emphasised the importance of the possibility for the people to participate in the political process (and the danger of their exclusion from it), cf. Chafetz 2007, introduction. 
[...] the real power in the state. As such, its position became more and more secure, and sweeping claims of privilege were no longer so necessary to protect it in the exercise of its legislative activities, and to guard it against encroachments from Crown, Lords, and courts. ${ }^{97}$

In 1604 the Commons resolved that it regarded itself a 'Court of Record, and so ever esteemed', 98 and a variety of cases - from the reign of Elizabeth I until the $19^{\text {th }}$ century - display this view and the struggle of the Commons for jurisdictional supremacy in cases of privilege. This began to change in the $19^{\text {th }}$ century. One notable case hinting in this direction was Burdett v. Abbot. ${ }^{99}$ Sir Francis Burdett, a member of the Commons, was arrested by order of the Commons for having breached the privileges of the House (contempt) by having published 'a libellous and slanderous paper'. The arrest involved armed soldiers entering Burdett's house by force. After having been imprisoned, he brought a suit against the Speaker of the House, Abbot, in the Court of King's Bench, alleging trespass and false imprisonment. The Court recognised that ' $[\mathrm{t}]$ he first and most important question [was], whether this Court can take cognisance of the question concerning privilege of Parliament which is brought in judgment before it in this cause'. Burdett's counsel argued that

\begin{abstract}
by laying the basis of Parliamentary privileges in the law of the land, and subjecting them to the examination and control of the Courts of Law, no arbitrary and despotic power can be exercised, and no person can be deprived of his liberty, without ultimate redress, except by a law made or recognized by the whole body of Parliament; whereby the one House may operate as a check upon the other, agreeably to the general principle of the Constitution, which is composed of checks and balancing powers. In such a Constitution it is of essential consequence that the legality of every act affecting the liberty of the subject should be open to the examination and trial of the Courts of Justice. ${ }^{100}$
\end{abstract}

Chief Justice Ellenborough, pondering this argument with care, replied that '[the House of Commons] certainly must have the power of self-vindication and selfprotection in their own hands', ${ }^{101}$ for

could it be expected that they should stand high in the estimation and reverence of the people, if, whenever they were insulted, they were obliged to wait the comparatively slow proceedings of the ordinary course of law for their redress? ${ }^{102}$

However, Ellenborough also inserts a highly important caveat into this reasoning:

Wittke 1970, p. 21.

Hatsell 1818, p. 233.

Burdett v. Abbott (1811) 104 ER 501.

Ibid., at 530-531.

Ibid,. at 559 .

Ibid. 
[...] if a commitment appeared to be for a contempt of the House of Commons generally, I would [...] [not] inquire further: but if it did not profess to commit for a contempt, but for some matter appearing on the return, which could by no reasonable intendment be considered as a contempt of the Court committing [id est, the House of Commons; note from the author], but a ground of commitment palpably and evidently arbitrary, unjust, and contrary to every principle of positive law, or national justice; I say, that in the case of such a commitment, (if it ever should occur, but which I cannot possibly anticipate as ever likely to occur) we must look at it and act upon it as justice may require from whatever Court it may profess to have proceeded. ${ }^{103}$

While the Court found unanimously in favour of the Speaker, the question mainly treated in Burdett $v$. Abbot is essentially whether or not lex parliamenti is in fact part of lex terrae. If so, there could be no doubt that cases like Burdett's are justiciable in the courts, since they are the administrators of the law of the land. Chafetz rightly points out that Ellenborough's statement above can mean two things for the positioning of lex parliamenti: if interpreted restrictively it says that the only power the courts have is that of 'policing the boundaries between the two distinct systems of law', ${ }^{104}$ thus implementing option (2) of Chafetz' categorisation (see above). Lex parliamenti would remain a legal system of its own right, the interpretation and enforcement of which is left entirely to Parliament. However, if interpreted more radically, Ellenborough's statement seems to actually plead for the treatment of lex parliamenti as a part of lex terrae, 'albeit a part in which judges should tread lightly'. ${ }^{105}$ This, in turn, would mean that the relationship between the two could be categorised as a somewhat tempered version of Chafetz' option (3). The latter was the view of the House of Lords when it affirmed the Court's ruling in Burdett $v$. Abbott. ${ }^{106}$ Lord Erskine expressed this view as follows:

My opinion is that these privileges are part of the law of the land, and upon this record there is nothing more than the ordinary proceeding; the Speaker of the House of Commons, like any other subject, putting himself on the country as to the fact, and pleading a justification in law; [...] Therefore, by this judgment, it appears that it is the law which protects the just privileges of the House of Commons, as well as the rights of the subject. ${ }^{107}$

Another case in which the same question was at stake was that of Stockdale $v$. Hansard. ${ }^{108}$ In this case, Stockdale sued Hansard, a publishing house, for libel. Hansard contended that the relevant publication had been printed by order of the Commons and that it was therefore protected by parliamentary privilege (as a proceeding in Parliament within the meaning of Article 9 of the Bill of Rights 1689). It was clear that papers printed for sole use in Parliament would have been subject to privilege as they would have constituted a part of Parliament's very own affairs.

Ibid., at 558-559.

Chafetz 2007, p. 38.

Chafetz 2007, p. 39

Burdett v. Abbott (1817) 3 ER 1289; 5 Dow 165 (H.L.).

Ibid, at 1301-1302

Stockdale v. Hansard (1839) 112 ER 1112. 
However, Stockdale contended that this was not true for papers printed for distribution to the public. Unfolding the old question of delimitation between lex terrae and lex parliamenti, this time employing the argument of its being a court of law, the Commons argued that they were competent, as a superior court, to judge over its own privilege, and that a statement issued by the Commons as to the extent of privilege was binding on any inferior court. The Court of Queen's Bench ruled otherwise. The presiding judge Lord Denman wrote:

I will dispose of the notion that the House of Commons is a separate Court, having
exclusive jurisdiction over the subject matter, on which, for that reason, its adjudication
must be final. The argument placed the House herein on a level with the Spiritual
Court and the Court of Admiralty, adopting this analogy; it appears to me to destroy
the defence attempted to the present action. Where the subject matter falls within their
jurisdiction, no doubt we cannot question their judgment; but we are now enquiring
whether the subject matter does fall within the jurisdiction of the House of Commons.
It is contended that they can bring it within their jurisdiction by declaring it so. To this
claim, as arising from their privileges, I have already stated my answer: it is perfectly
clear that none of these Courts could give themselves jurisdiction by adjudging that
they enjoy it. ${ }^{109}$

The above, first of all, displays a similar line of reasoning to what was followed in Burdett v. Abbot: the Court readily admits that it has no jurisdiction in matters internal to Parliament - but it does assume jurisdiction to determine whether or not the matter at hand actually is such an internal affair. And in Stockdale the King's Bench ruled that one must distinguish between documents printed for use within Parliament alone and documents published and sold 'indiscriminately'. The Court denied Hansard's claim of privilege and fined the publisher. Thereby it effectively set a limit to the absolute application of parliamentary privilege. As a consequence, Parliament, 'concerned by the wider implications of the decision', 110 passed the Parliamentary Papers Act 1840 shortly after, overruling Stockdale v. Hansard.

The Court's ruling in Stockdale appears highly questionable, since a publication ordered by Parliament can be seen as amounting to a deliberate act of communication of Parliament with the public. Arguably this falls within the core business of any representative legislature, at least pursuant to a modern understanding of parliamentary work. However, the more crucial point of Stockdale is that the Court, once again, assumed for itself the power to draw the line between lex parliamenti and lex terrae. At the same time, the ruling makes clear that the Court is not ready to intrude into the law of Parliament, namely, that it would not trespass the limit - set, however, by itself - of the law of the land. This, again, seems to hint at Chafetz' second option for the relationship between lex terrae and lex parliamenti. The courts can determine the extent (and thereby the limits) of the law of Parliament, but they cannot interpret and apply this body of law once they have decided that a matter falls within its territory. The same was reiterated by Lord 
Coleridge C.J., this time to the detriment of the plaintiff, in the case of Bradlaugh $v$. Gossett: 111

\begin{abstract}
It is said that in this case the House of Commons has exceeded its legal powers, because it has resolved that the plaintiff shall not take an oath which he has a right to take, and the threatened force is force to be used in compelling obedience to a resolution, in itself illegal. [...] Consistently with all the statements in the claim, it may be that the plaintiff insisted on taking the oath in a manner and under circumstances which the House had a clear right to object to or prevent. Sitting in this seat I cannot know one way or the other. But, even if the fact be as the plaintiff contends, it is not a matter into which this Court can examine. If injustice has been done, it is injustice for which the Courts of law afford no remedy. ${ }^{112}$
\end{abstract}

In Bradlaugh, the Court saw the facts it was called to adjudicate (the refusal of the Commons to let the atheist Bradlaugh take his oath) as a matter internal to Parliament. Consequently, it deferred to the jurisdiction of the House while recognising that the plaintiff may have suffered injustice and simply stating that it could not offer a remedy.

With Burdett, Stockdale and Bradlaugh, the 19th century seems to have been marked by a general movement away from Chafetz's 'Blackstonian' model of the relationship between lex terrae and lex parliamenti, and towards the 'Millian' model, but not entirely getting there yet: indeed the courts did loosen Parliament's grip on one of the two decisive powers - the power to determine the extent of the law of Parliament, and thereby of privilege. The power to interpret and apply this law, however, remained quite firmly in the hands of Parliament. On a more subtle level it can also be noted that Stockdale was the strongest of the three cases on the lex terrae side, in that the King's Bench outrightly contradicted the judgment of the Commons, provoking the Parliamentary Papers Act 1840 to be adopted promptly, in direct opposition to the ruling. Chafetz notes that this might have incited the Court to back-pedal to some extent in Bradlaugh. ${ }^{113}$

The easing up of Parliament's stance with regard to lex parliamenti and its privileges did not continue without interruption in the $20^{\text {th }}$ century, with more case law adding another layer of historic uncertainty and inconsistent precedents to the difficulties in determining the relationship between the law of the land and the law of Parliament. One of these cases was that of Graham-Campbell, mentioned earlier (see section 2.6 above), in which the Court was not ready to hold the manager of the House of Commons's bar (a servant of the House) responsible under the Licensing Act 1910. Crucially, the Court did not engage in a more detailed discussion of whether or not there needs to be a functional connection to the work of the House in addition to the matter at stake being spatially 'internal to the House'. In this respect it merely stated that 
The House sits for long periods and arrangements have to be made for [...] refreshment for the body in suitable places. The regulation of those matters is clearly within the area of the internal affairs of the House and connected with the affairs of the House. ${ }^{114}$

The fact that (the Kitchen Committee of) the House had allowed the contested sale of liquor without a licence satisfied the Court that this sale should be privileged:

[I]n the matters complained of the House of Commons was acting collectively in a matter which fell within the area of the internal affairs of the House, and, that being so, any tribunal might well feel, on the authorities, an invincible reluctance to interfere. ${ }^{115}$

This appears to be a leap backwards by the Court, which in this case again seems to have followed the 'Blackstonian' rather than the more up to date 'Millian' understanding of privilege. In Stockdale the reluctance of the judges to interfere was apparently not so strong as to prevent them from deciding that publications ordered by Parliament are not subject to privilege, even though the House had resolved, 'acting collectively', that they should. The argument that Stockdale must be distinguished from Graham-Campbell, since the publication of parliamentary papers, as opposed to the sale of liquor in Westminster Palace, has a connection to the outside world: This can be countered by the observance that ordering the publication of papers is clearly part of the natural workings of any parliament which one is perhaps inclined to deem less true for the sale and consumption of liquor. Consequently, Graham-Campbell must be seen as a backslide to the age of Blackstone.

This applies similarly if not more strongly to the case In Re Parliamentary Privilege Act 1770 [the case of Strauss] of $1958 .{ }^{116}$ In this case, the London Electricity Board threatened to bring a libel suit against Strauss, a member of the Commons, over a letter sent by Strauss to the paymaster general in which he criticised the Board. At the time, the Commons' Committee on Privileges quickly declared that the letter was privileged under the Bill of Rights 1689 as a proceeding in parliament (see section 3.1). ${ }^{117}$ The Committee then requested an Advisory Opinion from the Privy Council to determine whether the House could, considering the Parliamentary Privilege Act 1770, treat the bringing of a suit over a privileged matter as a breach of privilege. In this respect, the Parliamentary Privilege Act $1770^{118}$ provides in section 1 that:

Ibid., at 598-599.

Ibid., at 602 .

In Re Parliamentary Privilege Act 1770 (1958) AC 331 (P.C.).

In a later committee vote, however, this view was curiously not adopted. This seems an unnecessarily narrow view of 'proceedings in Parliament'. Cf. Chafetz 2007, Chapter 1, notes 50 and 87.

$118 \quad 177010$ Geo. 3 c50: An Act for the further preventing Delays of Justice by reason of Privilege of Parliament. 
[A]ny person [...] shall and may at any time commence and prosecute any action or suit in any court of record [...] against any [member of Parliament] or any other person entitled to the privilege of Parliament [...]; and no such action [...] shall at any time be impeached, stayed, or delayed by or under colour or pretence of any privilege of Parliament.

The Privy Council answered the question of the Committee in the affirmative; the act of suing over a privileged matter had already been considered as a breach of privilege. This conclusion seems strangely at odds with the very wording of section 1 of the Parliamentary Privilege Act 1770 quoted above. The Privy Council reached it by inferring a limitation of the scope of said section 1 from a juxtaposition of this Act with the 'Act for preventing any inconveniences that may happen by privilege of Parliament' of $1700 .{ }^{119}$ Section 1 of that Act allowed subjects to bring against Peers and members of Parliament such actions 'for which they have cause or suit of action'. On the basis of this formulation the Privy Council held that 'by clear implication [the Section] referred only to those suits which [...] were ultimately enforceable ${ }^{\prime 120}$ - and thus not to suits barred by privilege. Reasoning that the Act of 1770 was, in principle building on the Act of 1700 and it clearly did not intend to abrogate from the Bill of Rights 1689, the Lords of the Privy Council went on to hold that:

the Act [of 1770] applies only to proceedings against members of Parliament in respect of their debts and actions as individuals and not in respect of their conduct in Parliament as members of Parliament, and does not abridge or affect the ancient and essential privilege of freedom of speech in Parliament. ${ }^{121}$

The line of reasoning followed by the Privy Council in Strauss seems somewhat adventurous. It is clear that the Lords wanted to avoid calling into question the continued validity of Article 9 of the Bill of Rights, but the judgment leaves little doubt that the Privy Council did not feel completely at ease with the Opinion it expressed; after all, the Lords thought it necessary to add that they did

not intend expressly or by implication to pronounce upon any other question of law. In particular they express no opinion whether the proceedings referred to in the introductory paragraph were 'a proceeding in Parliament,' a question not discussed before them $[\ldots] .^{122}$

But even if we consider the latter statement to be a courteous note of complaint of the House's interpretation of 'proceedings in Parliament' it is clear that Strauss is a further instance of the Privy Council's back-pedalling to the 'Blackstonian' concept of lex parliamenti and privilege.

The majority of the Law Lords in the Council in Strauss seem to have overlooked a much more logical and elegant way to fit section 1 of the

170012 \& 13 Will. 3, c3.

In Re Parliamentary Privilege Act 1770 (1958) AC 331 (P.C.), at 350.

Ibid.

Ibid., at 353. 
Parliamentary Privilege Act 1770 into a modern concept of privilege and jurisdiction which leaves the Bill of Rights intact. Section one could also be interpreted as being directed at the courts, explicitly allowing them to hear, in principle, 'any action or suit' against a member. The courts would then still be obliged, under the Bill of Rights and by virtue of other privileges, to stay outside the off-limits territory of exclusive cognisance. However, they would have jurisdiction - very much in line with the 'Millian' concept - to determine the boundaries of that territory. This way a plaintiff would have been free to commence a suit against a member without thereby running the risk of breaching privilege. If pursuing the action in Court had subsequently infringed upon privilege in any way, the courts would have had to stay proceedings. This view was held, in an unpublished dissenting Opinion, by Lord Denning. ${ }^{123}$

A series of important case law at the end of the 20th and the beginning of the $21^{\text {st }}$ century seems to indicate that the tide has turned, at last, in favour of what Chafetz calls the 'Millian' concept of parliamentary privilege. Whereas in 1972 the judges denied themselves access to parliamentary proceedings (by means of consulting Hansard) to be used as evidence against a member of the Commons in a libel action in Church of Scientology v. Johnson-Smith, 124 the House of Lords undertook quite a far-reaching excursion into the territory of the law of Parliament in the famous case of Pepper $v$. Hart ${ }^{125}$ of 1993 . On the substance, this case revolved around the definition of the word 'cost' in section 63 of the Finance Act 1976.126 Reference to Hansard was desirable here in order to clarify the intended meaning of the concept of 'cost' in legislation and, crucially, not in order to obtain evidence against a member or indeed to 'impeach or question' what has been said in Parliament. This would remain off limits as the very essence of Article 9 of the Bill of Rights. It must also be noted that the rule which barred the courts from referring to Hansard cannot be held to be part of that old-ancient privilege but was judge-made, ${ }^{127}$ and that other references, especially with regard to ministerial statements in Parliament, had occasionally been made, even if for other purposes (mainly to determine the purpose of government policy and of legislation).

The novelty of Pepper consisted in the intended use of Hansard to establish the true meaning of legislation: in pondering what had been said in Parliament, the judges would search for hints as to the intended meaning of the statutory provision in question. Apparently, the House of Lords was now ready, in Johnson Smith as well as in Pepper (only with different outcomes), to apply functional criteria in delimiting the reach of parliamentary privilege. In order to do this, they had to express a judicial opinion - that is, assume jurisdiction! - on the question of what the aim of privilege is, and so determine whether or not allowing reference to Hansard carries the risk of jeopardising that aim. Lord Browne-Wilkinson acknowledged that, if the judges extended the boundaries of lex parliamenti as far as

Chafetz 2007, p. 42.

Church of Scientology v. Johnson-Smith (1972) 1 QB 522.

Pepper v. Hart (1993) AC 593 (H.L.).

Oliver 1993, p. 5-13.

Ibid. 
they did in Pepper, they would have to be 'astute to ensure'128 that privilege, where it applied, be upheld during court proceedings. However, he was of the opinion that judges were able to do so and thus had no reason to leave to Parliament what was not for Parliament to have: privilege irrespective of the function parliamentary proceedings would serve in court.

It is clear that Pepper $v$. Hart carries far-reaching implications for the interpretation of Article 9 of the Bill of Rights, and these will be discussed in more detail in part IV of this chapter. However, Pepper is also a striking move in the evolution of the relationship between lex parliamenti and lex terrae and the connected question of jurisdiction: while cautiously pointing out that the Law Lords

[...] are motivated by a desire to carry out the intentions of Parliament in enacting legislation and have no intention or desire to question the processes by which such legislation was enacted or of criticising anything said by anyone in Parliament in the course of enacting it $[\ldots] .{ }^{129}$

In what was probably one of the sharpest statements on the position of privilege vis$\grave{a}$-vis the law of the land ever made in a court ruling, Lord Browne-Wilkinson also elaborated that

[a]lthough in the past the courts and the House of Commons both claimed the exclusive right to determine whether or not a privilege existed, it is now apparently accepted that it is for the courts to decide whether a privilege exists and for the House to decide whether such privilege has been infringed[...]. ${ }^{130}$

This seems to be a conclusive departure from the 'Blackstonian' concept of privilege and the relationship between lex terrae and lex parliamenti, expanding the powers of the courts and limiting those of Parliament. While this is true if one regards privilege alone, it can certainly be argued ${ }^{131}$ that the role of the courts as a constitutional corrective might very well be weakened by allowing reference to Hansard for the interpretation of statutes. Previously the judges, barred from taking (official) cognisance of parliamentary proceedings, employed a range of judicial presumptions which enabled them to uphold certain constitutional principles. Oliver lists as examples the presumption that Parliament cannot have intended to breach treaty obligations or the presumption that Parliament did not intend to oust the jurisdiction of the courts. ${ }^{132}$

Further, the courts habitually strike from the list of possible meanings of statutory provisions what they hold to be absurd, presuming that the legislators cannot have intended the absurd to become law. Pepper opened up the possibility for the courts to take Parliament literally in construing the meaning of statutory provisions, at least where there is no danger of an infringement of privilege.

Pepper v. Hart (1993) AC 593 (H.L.), at 639.

Ibid., at 646 .

Ibid., at 645 .

Cf. Oliver 1993

Ibid. 
However, the case seems to have also limited the courts' room for manoeuvre since they cannot depart as easily from what has been said in Parliament. Taking into account that many parliamentary speeches (and other proceedings, such as the tabling of bills) are delivered by the executive, it is not inconceivable that the Pepper rule may ultimately have strengthened the executive and weakened, in turn, the judiciary - both at the expense of parliamentary independence.

Where the courts have jurisdiction to hear suits brought by members of Parliament against non-members, the situation may arise that privileged material (such as a speech that a member gave in Parliament) is required as evidence for the defence. This is problematic because privilege accrues to Parliament (or one of its constituent Houses) as a body, and not to the individual member (this issue will be discussed in more detail in part IV). As a result, the member does not have privileged material at his free disposal; he may not allow the courts to use such material as evidence. This raises a further question of jurisdiction: may the court proceed with a suit brought by a member of Parliament where the suit itself is not barred by privilege but where, by reason of privilege, the defendant is placed at a disadvantageous position due to limited access to privileged evidence? This was the question the Privy Council had to deal with in Prebble v. Television New Zealand. ${ }^{133}$ Prebble, a member of the New Zealand House of Representatives and former minister, had brought charges of defamation against TV New Zealand about a television programme in which it was alleged, among other things, that Prebble had conspired to sell state assets to private parties in return for generous donations to the New Zealand Labour Party. TVNZ contended that the relevant allegations raised in the programme were justifiable as true, as could be evidenced by statements made by Prebble in the House. These statements, however, were privileged by virtue of Article 9 of the Bill of Rights 1689. TVNZ requested privilege to be waived in order for Prebble's speeches to be admitted as evidence in court. This request was denied after the Privileges Committee of the House of Representatives 'decided that the House has no power to waive Parliamentary privilege'. ${ }^{134}$ The Privy Council was now faced with the question if and how the courts are able to proceed in such a situation. The Lords of the Privy Council held that

[t]here may be cases in which the exclusion of material on the grounds of Parliamentary privilege makes it quite impossible fairly to determine the issue between the parties. In such a case the interests of justice may demand a stay of proceedings. But such a stay should only be granted in the most extreme circumstances. ${ }^{135}$

133 Prebble v. Television New Zealand (1995) 1 A.C. 321 (P.C.). The case is relevant to the UK since it involves the application of Art. 9 of the Bill of Rights 1689 which is also law in New Zealand. Further, New Zealand abolished Commonwealth appeals to the Privy Council only in 2003, in favour of the new NZ Supreme Court. Privy Council rulings originating in Commonwealth jurisdictions possess precedence value in the UK, provided that the relevant law is mutually applicable.

$134 \quad$ Ibid., at 321

135 Ibid., at 338. 
The relevance of Prebble for our quest to understand the relationship between the law of Parliament and the law of the land, and to gauge the extent of court jurisdiction in cases involving privilege, results from the clarity the case adds to previous developments. It is clear that any use of parliamentary proceedings that would be intrusive to Article 9 of the Bill of Rights remains off-limits (see part IV). However, it is within the power of the courts to 'prevent lex parliamenti from adversely affecting the operations of lex terra'. ${ }^{136}$ by ordering a stay where necessary. Jurisdiction to determine what constitutes an 'extreme case' rests, of course, firmly with the courts (this question does not touch upon Parliament in any way; the courts will decide it on the basis of the amount of evidence available to them). In Prebble the Privy Council also recognised an additional function of parliamentary proceedings as subject to privilege:

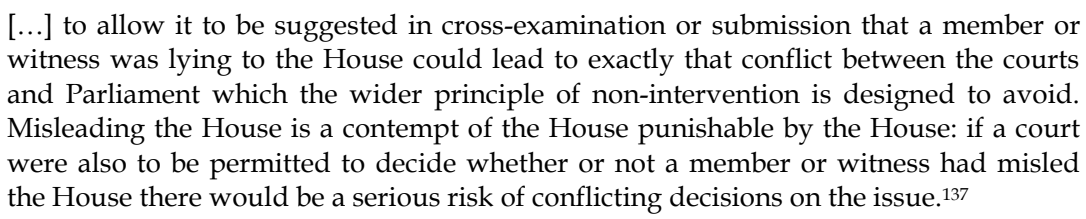
witness was lying to the House could lead to exactly that conflict between the courts and Parliament which the wider principle of non-intervention is designed to avoid. Misleading the House is a contempt of the House punishable by the House: if a court were also to be permitted to decide whether or not a member or witness had misled the House there would be a serious risk of conflicting decisions on the issue. ${ }^{137}$

Thus, the Council was of the opinion that privilege must be observed by the courts not merely as an act of deference with regard to the powers of Parliament, but also for the avoidance of inter-institutional conflict, this being one of the main functions of privilege.

\subsection{The Defamation Act 1996}

Case law from the late $20^{\text {th }}$ century, including Pepper and Prebble and Chaytor, seem to lead up to a fair degree of clarity on the question of jurisdiction and the delimitation between the sphere of lex parliamenti and that of the law of the land. However, matters have been complicated in one area of law which is particularly relevant in the context of speech in Parliament - the law of defamation. The Defamation Act 1996, 138 in particular section 13 of this Act, constitutes a significant encroachment on Article 9 of the Bill of Rights 1689. Section 13 provides, inter alia, that

(1) Where the conduct of a person in or in relation to proceedings in Parliament is in issue in defamation proceedings, he may waive for the purposes of those proceedings, so far as concerns him, the protection of any enactment or rule of law which prevents proceedings in Parliament being impeached or questioned in any court or place out of Parliament.

Chafetz 2007, p. 44

Prebble v. TVNZ (1995) 1 A.C. 321 (P.C.), at 334.

1996 c31 An Act to amend the law of defamation and to amend the law of limitation with respect to actions for defamation or malicious falsehood. 
(2) Where a person waives that protection-

(a) any such enactment or rule of law shall not apply to prevent evidence being given, questions being asked or statements, submissions, comments or findings being made about his conduct, and

(b) none of those things shall be regarded as infringing the privilege of either House of Parliament.

\section{$[\ldots]$}

The passing of section 13 of the Defamation Act must be seen as a most remarkable and incisive event in the development of the relationship between lex terrae and lex parliamenti as it opens up - or rather, completely removes - parliamentary privilege in defamation suits where the member concerned so wishes, without a decision of the House, a committee or the Speaker. In such cases, individual members can therefore relinquish lex parliamenti jurisdiction on behalf of their entire House, though only with regard to themselves, and instead allow the courts to extend lex terrae jurisdiction into the very core of Parliament's internal affairs and the parliamentary legal system.

It is worthwhile to look into the genesis of section 13, which was inserted into the Defamation Bill by way of an amendment put forward in the Committee by Lord Hoffman while the Bill was discussed in the Lords. It has been observed that only four Lords were present when the amendment was put forward and that it was not discussed at length before the third reading. ${ }^{139}$ The Commons, eager to pass the Act quickly, did not reconsider the amendment at great length before giving their approval. This course of events was recognised and criticised by scholars as a severe procedural flaw. It was contended, among other things, that 'so significant an amendment to the Bill of Rights 1689 should more properly be the subject of investigation by a joint committee of both Houses' ${ }^{140}$

The tabling of the amendment by Lord Hoffmann is seen to have been a reaction ${ }^{141}$ to the first stage of the saga which was to end with the case of Hamilton $v$. Al Fayed. ${ }^{142}$ Following the publication of an article in the newspaper The Guardian in which it was alleged that Mr Hamilton MP had received material benefits from the businessman Mohamed Al Fayed, Hamilton, Rupert Allason MP143 and the lobbyist Ian Greer ${ }^{144}$ sued the authors and The Guardian for defamation, but the action was stayed on the grounds of the Prebble rule: the defendants would have had to rely on parliamentary statements by Hamilton and Allason to justify the allegedly defamatory allegations made in the paper. Since the use of these statements in court was precluded by privilege, the court declared the case irresolvable and stayed

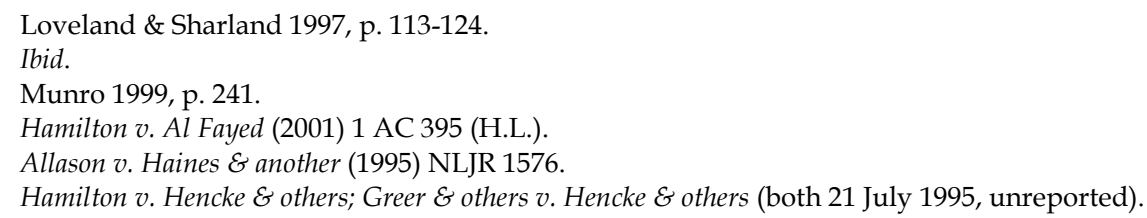


proceedings accordingly. Hamilton was thus left without a remedy and had no opportunity to clear his name.

After the enactment of the Defamation Act, Hamilton sued Mr Al Fayed (the suit against the journalists and The Guardian was not reopened) ${ }^{145}$ who had in the meantime publicly admitted having rewarded Hamilton in cash and other means for asking questions in Parliament and generally championing his business interests in Parliament and vis-à-vis the Government. While the problem as regards privilege was essentially identical in this new lawsuit, this time Hamilton had at his disposal the new instrument of a section 13 waiver, of which he made use. In Hamilton $v$. Al Fayed the question arose whether such a waiver entailed that statements in parliament (in this particular case in a committee of the Commons) could also be challenged (thus not merely be used as evidence against the non-member party, or used for the construction of statutes, but also questioned with regard to their truth) in the courts. It was held by the House of Lords that indeed in case of a waiver the utterances in the committee could be challenged in order to enable the other party to make a defence. ${ }^{146}$ In the course of the defence, counsel for Mr. Al Fayed raised the interesting argument that a section 13 waiver could only concern such privileges as were enjoyed by individual members, but not those enjoyed by the House as body, among which was its 'autonomous jurisdiction over certain matters'. ${ }^{147}$ However, this argument was summarily dismissed by Lord Browne-Wilkinson, stating that

\footnotetext{
[t]his argument is fallacious. The privileges of the House are just that. They all belong to the House and not to the individual. They exist to enable the House to perform its functions. Thus section 13(1) accurately refers, not to the privileges of the individual $\mathrm{MP}$, but to 'the protection of any enactment or rule of law' which prevents the questioning of procedures in Parliament. The individual MP enjoys the protection of parliamentary privilege. If he waives such protection, then under section 13(2) any questioning of parliamentary proceedings [...] is not to be treated as a breach of the privilege of Parliament. ${ }^{148}$
}

With regard to the intended meaning of section 13, this assessment is certainly correct. After all it has repeatedly been put forward in doctrine, practice and case law that parliamentary privilege belongs to Parliament (or, more particularly, its constituent Houses) as a body and not to individual members. Recognising this principle, however, is only one little step short of identifying one very fundamental flaw of section 13. For, as mentioned earlier, one can say that section 13 essentially allows members, who are not the primary beneficiaries of privilege, nor the bearers of jurisdiction with regard to it, to abandon privilege on behalf of the respective House. They may do so where they see it as beneficial for themselves to submit the share of 'proceedings in Parliament' which relates specifically to the jurisdiction of

Ibid.

Ibid., at 408-409. 
lex terrae. More dramatically, they may do so without approval, or even consultation, of the House of which they are a member.

These are not petty theoretical problems of irrelevance beyond the doctrine of lex parliamenti and lex terrae which has been (further) complicated by the Defamation Act. It has widely been held that section 13 entails a variety of technical problems which 'range from the constitutional to the practical'. ${ }^{149}$ Practically, the (yet) hypothetical case has been put forward in which two members are involved in defamation proceedings, only one of whom opts for the waiver. It will be extremely difficult for any court to investigate parliamentary proceedings with regard to one member without breaching privilege with regard to the other. And even if the court succeeds in doing so, the defence might request (and be entitled to) a stay according to the Prebble rule as it will still be in a disadvantaged position. ${ }^{150}$

Further, in a certain sense privilege worked both ways prior to the Defamation Act. Parliamentarians were safe from being sued for what they said in Parliament. Of course, this has been left unchanged, since the waiver is only an option, fully at the disposal of the member. ${ }^{151}$ However, the media and private parties were also relatively safe from defamation suits against them, instituted by parliamentarians, at least in cases which would have necessitated the use of parliamentary proceedings as evidence and thus would have led to a Prebble stay of proceedings. The possibility of a waiver takes away much of that certainty; and it has been argued that this might lead to a 'chill' in the publication of critical news. ${ }^{152}$ In other words, section 13 might even carry implications, probably wholly unintended, for the freedom of the press.

It is certain that the overall integrity of privilege, theoretically belonging to Parliament as a body, has been weakened by section 13: even though the waiver is nominally nothing but an option, it is not beyond imagination that members will often be coerced to opt for the waiver if faced with the consequence of otherwise having their defamation suits stayed. Since the Commons did not reserve for themselves or the speaker the right to approve or disapprove of a section 13 waiver, the extent to which their proceedings will be 'questioned' is now practically beyond their control.

Aside from such criticism, with the Defamation Act and the confirmation of its face value by case law in Hamilton $v$. Al Fayed, the development of the relationship of the law of Parliament and the law of the land, and the question of jurisdiction so closely attached to it, has clearly moved further away from the 'Blackstonian' concept of privilege. Putting it in dramatic terms, this last stage of the development

Williams 1997, p. 390

Ibid. See also Loveland \& Sharland 1997.

Which in itself has been held to be unfair, since 'MPs themselves readily abused their protection from defamation suits by making unsupportable accusations in the House. [Lord Ewing of Kirkford] suggested that to leave the victim of such defamation without a remedy, while enhancing the remedies available to MPs was not an appropriate course for Parliament to follow'. Loveland 2000, p. 158

152 Loveland \& Sharland 1997. 
described here may have started to erode Article 9 of the Bill of Rights, one of the most fundamental components of British parliamentary privilege.

It is possible that section 13 was a step that necessarily had to follow in what can be seen as a sort of chain reaction after Pepper and Prebble: whereas especially the latter case served to secure procedural fairness for the non-privileged party to a defamation dispute as proceedings had to be stayed where the non-privileged party was rendered defenceless by the privilege of the other, there was, after Prebble, still no remedy for a privileged person being defamed, as she could not waive her privilege before the enactment of the Defamation Act (the argument being that privilege accrued to Parliament as a body and individual members thus could not waive it). This imbalance was remedied by the Defamation Act, tilting the imbalance back to the disadvantage of the non-privileged party, as long as she could still not challenge statements in Parliament, now exempt from privilege, which could, however, be used as evidence against her. This, in turn, had to be remedied in the case of Hamilton. However, the arguments against section 13 briefly outlined above show that it is at least doubtful whether at the end of this chain of changes in the law that there is now an actual procedural equilibrium. It is very possible that the damage done by section 13 to the doctrinal framework of privilege, but also to its practical value, outweighs its benefits. The problems created by the Defamation Act 1996 have not gone unrecognised; new statutory legislation, either on the law of defamation or on parliamentary privilege is likely to be enacted soon. This will be addressed in our discussion of recent developments with regard to the privilege ex Article 9 of the Bill of Rights further below.

\subsection{The Parliamentary Expenses Scandal and $R$ v. Chaytor: The End of Exclusive Cognisance?}

The current state of affairs as regards the boundary between lex parliamenti and lex terrae has recently been illustrated, and perhaps shifted even further towards the 'Millian paradigm' by case law in the wake of the parliamentary expenses scandal. This major political scandal erupted in 2009 , after a request by journalists under the Freedom of Information Act 2000,153 initially challenged by Parliament without success, 154 forced the House of Commons to release details about the expenses claimed by its members. The House announced that the requested information would be released in July 2009, but with the exception of 'sensitive' information. However, in May, the Daily Telegraph newspaper had already started publishing uncensored information about members' expenses ${ }^{155}$ which had been leaked to the paper from the House of Commons fees office. ${ }^{156}$ As a result of the information revealed by the Telegraph, a number of fraudulent expenses claims were discovered,

1532000 c. 36 . The Act entered into force on 1 January 2005.

154 Corporate Officer of the House of Commons v. Information Commissioner (2008) EWHC 1084 (Admin).

155 'Full list of MPs investigated by The Telegraph', The Telegraph online, 8 May 2009.

156 'Police hunt expenses mole', The Daily Mail online, 9 May 2009. 
leading to widespread public outrage, resignations and de-selections and, ultimately, criminal proceedings against a number of members. ${ }^{157}$

The members of the House of Commons, Chaytor, Morley and Devine as well as Lord Hanningfield were accused of false accounting under the Theft Act 1968. Among others, they were accused of claiming cost allowances for rent which had never been paid (Chaytor), mortgage interest for a mortgage which had already been repaid (Morley), and service costs for services which had not been supplied (Devine). After the defendants had been convicted ${ }^{158}$ and their appeals dismissed, ${ }^{159}$ their case was decided by the Supreme Court in the final instance (Lord Hanningfield did not join in this final appeal). ${ }^{160}$

This case is important because it illustrates the current state of parliamentary privilege in two respects. First, Chaytor and the other defendants argued that their expenses claims were subject to privilege as proceedings in Parliament under Article 9 of the Bill of Rights 1689. This gave the Supreme Court the opportunity to consider once again the scope of the concept of proceedings in Parliament. We are going to address this part of the ruling later, but for a better understanding of the case it should be pointed out that the Court did not deem the claims and their administrative processing 'proceedings' in Parliament. Second, however, the defendants also claimed that, even if expenses claims did not constitute proceedings in Parliament, their case fell within the category of 'internal affairs' over which Parliament enjoys exclusive cognisance. The Supreme Court therefore had to review - quite independently of the question what constitutes proceedings in Parliament the line of demarcation between the jurisdiction of the courts and that of Parliament, between lex terrae and lex parliamenti.

In $R v$. Chaytor and others, the President of the Supreme Court, Lord Phillips, notes that the phrase exclusive cognisance 'describes areas where the courts have ruled that any issues should be left to be resolved by Parliament rather than determined judicially'. He thus recognises, first of all, that the line of demarcation between the jurisdiction of Parliament and that of the courts is for the latter to draw, even though he realises that the boundaries of exclusive cognisance result from accord between the two Houses and the court as to what falls within the exclusive province of the former'. ${ }^{161}$ Lord Phillips then reiterates that exclusive cognisance can be relinquished by Parliament, that its field of application has been significantly reduced in the past as a result of legislation. ${ }^{162}$ He refers to $R v$. Graham-Campbell ex parte Herbert, according to which legislation does not apply within Parliament unless it explicitly provides so, but also to the 1999 report of the Joint Committee on

157 The scandal has also led to more transparency with regard to members' expenses. As of 18 June 2009, information about the allowances paid to both members of the Commons and Lords is published on the website of Parliament.

$158 \quad R$ v. Morley, Chaytor, Devine and Hanningfield, Southwark Crown Court, judgment of 11 June 2010 by Saunders J. (unreported).

159 R v. Morley, Chaytor, Devine and Hanningfield (2010) EWCA Crim. 1910.

$160 \quad R v$. Chaytor and others (2010) UKSC 52.

161 Ibid., para. 63

162 Ibid. 
Parliamentary Privilege, which has noted that Parliament sometimes chooses to abide by statute in its internal affairs, even where an Act does not contain an explicit provision to that effect. Paragraphs 72 and 73 of the judgment quote the report of the Joint Committee which has tried to define the boundaries of exclusive cognisance:

\begin{abstract}
Perhaps the nearest approach to a definition [of exclusive cognisance] is that the areas in which the courts ought not to intervene extend beyond proceedings in Parliament, but the privileged areas must be so closely and directly connected with proceedings in Parliament that intervention by the courts would be inconsistent with Parliament's sovereignty as a legislative and deliberative body. [...] It follows that management functions relating to the provision of services in either House are only exceptionally subject to privilege. [...] The boundary is not tidy. Occasionally management in both Houses may deal with matters directly related to proceedings which come within the scope of Article 9. For example, the members' pension fund of the House of Commons is regulated partly by resolutions of the House. So too are members' salaries and the appointment of additional members of the House of Commons Commission under section $1(2)(d)$ of the House of Commons (Administration) Act. These resolutions and orders are proceedings in Parliament, but their implementation is not. ${ }^{163}$
\end{abstract}

In line with the report of the Joint Committee, Lord Phillips adopts a narrow view of the area of exclusive cognisance with regard to administrative matters: where decisions in relation to matters of administration are taken by parliamentary committees - that is, by parliamentarians - these decisions are protected by privilege. However, administrative acts and procedures which exist pursuant to such decisions are not. ${ }^{164}$

According to Lord Phillips's assessment, extensive inroads have been created into areas which previously fell squarely within the exclusive cognisance of Parliament. These inroads are the results of numerous explicit statutory encroachments into exclusive cognisance which, for instance, allow the application of the laws of contract and tort within (the administration of) Parliament, but also of instances at which Parliament has voluntarily accepted the application of statute. In addition, Parliament itself does not (or no longer) interpret(s) exclusive cognisance broadly, as evidenced by the distinction which the Joint Committee has observed between, on the one hand, actions and decisions of the House itself or one of its committees and, on the other hand, the dealings of the administration of the House. As a result, the doctrine of Graham Campbell - that statute does not apply within Parliament unless it provides so and that the courts, consequently, lack jurisdiction - now appears questionable. ${ }^{165}$ Since this case was decided in 1935, the area of exclusive cognisance has diminished more and more; the area over which Parliament has exclusive jurisdiction is now not much broader than the scope of Article 9 of the Bill of Rights - only proceedings in Parliament and matters which are immediately connected with it remain off-limits to the courts.

163 Report of the Joint Committee on Parliamentary Privilege, HL 43-1, HC 214-1 (1998-99), paras. 247-248.

$164 \quad$ R v. Chaytor and others [2010] UKSC 52, para. 89

165 Ibid., para. 78 
With regard to criminal conduct in Parliament, Lord Phillips recalls that 'Parliament has never challenged, in general, the application of the criminal law within the precincts of Parliament and has accepted that the mere fact that a crime has been committed within these precincts is no bar to the jurisdiction of the courts'. ${ }^{166}$ This may, of course, lead to overlapping jurisdiction where a crime also constitutes a contempt of Parliament. ${ }^{167}$ Where this is the case, Parliament remains free to exercise its penal powers, but the House does not assert an exclusive jurisdiction to deal with criminal conduct, even where this relates to or interferes with proceedings in committee or in the House'. ${ }^{168}$ In evidence of this, Lord Phillips refers to an agreed statement of the Chairman of the Committee on Standards and Privileges, the Parliamentary Commissioner for Standards, and the Commissioner of the Metropolitan Police regarding their mutual cooperation and coordination in the investigation of alleged criminal conduct in the House. ${ }^{169} \mathrm{He}$ also refers to the conviction of a former budget officer in the House of Commons fees department, who had organised money transfers to himself by drawing up false invoices in the names of former MPs. ${ }^{170}$ Accordingly, there is precedent for the application of criminal law to conduct within Parliament, and even for the cooperation of Parliament therein.

A further interesting argument against the claim of the defendants - that their prosecution in court is barred by exclusive cognisance - is made by Lord Clarke in his separate concurring Opinion. He argues that, since indeed the privilege of exclusive cognisance can be waived or relinquished by Parliament, and since Parliament has apparently done so for cases of criminal conduct in one of the Houses, it is not for individual members to claim this privilege. He recognises that this view is inconsistent with older case law from the $19^{\text {th }}$ century, according to which the courts cannot take cognisance of anything from within Parliament except

166 Ibid., para. 80. This is certainly the case for 'big crimes': the judgments refer to the murder of Prime Minister Spencer Percival at the entrance to the lobby of the House of Commons in 1812. His murderer, John Bellingham, was tried and convicted in court; the House did not assert exclusive jurisdiction. However, less important cases and cases intimately related to the parliamentary business were not always left to the courts, see infra.

167 Ibid., paras. 81-82. Lord Phillips recalls an incident in 1988, when Ron Brown MP 'damaged the mace in the course of a heated debate and declined to apologise'. At the time, the House of Commons made use of its penal powers; a private prosecution in court was halted by the director of Public Prosecution.

168 Ibid., para. 83. At times, the House has even directed the Attorney General to prosecute offenders.

169 Ibid., para. 84

$170 \quad R v$. Gibson, Southwark Crown Court, judgment of 30 September 2010 by Rivlin QC, case No. T T20107344. 
enacted legislation. ${ }^{171}$ Lord Clarke contends, however, that this view is outdated and 'sounds odd to modern ears'. ${ }^{172}$

All the above has led the Supreme Court to the conclusion that exclusive cognisance did not bar the prosecution of Chaytor and the other defendants for fraudulently submitting false expenses claims. Since these claims and their administrative processing could also not be deemed proceedings in Parliament under Article 9 of the Bill of Rights, the three members of the Commons (and Lord Hanningfield) could be tried and convicted in ordinary courts. The impact of $R v$. Chaytor and others on the relationship between lex parliamenti and lex terrae can hardly be overestimated: the case has made it clear that the privilege of exclusive cognisance, as regards matters which are not specifically under privilege as proceedings in Parliament - has all but lost its relevance. First, according to the Supreme Court's ruling in Chaytor, it is for the courts to decide what falls within the area of exclusive cognisance (even though the courts will consider the views expressed by Parliament). Second, exclusive cognisance only extends to matters which are very closely connected with proceedings in Parliament. Administrative operations in either House do not fall under it, even though the administrative schemes under which they may take place have in fact been adopted by decisions of the House or committees which must be deemed proceedings. Third, although the Houses retain jurisdiction over contempt, they have relinquished exclusive cognisance with regard to criminal conduct, even where it relates to proceedings.

\subsection{Lex Parliamenti and Lex Terrae: Conclusions}

After centuries of development in case law, statute and, not least, political culture, what is the nature of the relationship between lex et consuetudo parliamenti and lex terrae in the United Kingdom? Is it (still) apt to speak of two separate legal systems, one governing, and entirely governed by, Parliament and one for the outside world, or is there only one, albeit one with a special autonomous zone to allow Parliament to carry out its constitutional tasks? More practically speaking, how are the two facets of power, delimitative and interpretative authority, divided between Parliament and the Courts? Who has what to say with regard to parliamentary privilege?

It has been shown, first of all, that this relationship is anything but static: there has been tremendous change in the distribution of jurisdiction. More has changed, it is true, with regard to the delimitative power than with regard to the interpretative power: as Lord Browne-Wilkinson made clear in Pepper v. Hart, it is now for the courts to determine whether a privilege exists, that is, whether a matter is covered by privilege so as to bar jurisdiction of the courts. However, where this is the case, it

\footnotetext{
171 In particular, he cites Wellesley v. Beaufort (1827) 2 Russell 1; 28 ER 236 in which Lord Brougham LC held that '[the] Court is [...] bound to give [the defendant] the benefit of his privilege, and to give it to him with all its incidents, even although the House to which he belongs abandons it as a claim of right; for a Court knows nothing judicially of what takes place in Parliament till what is there done becomes an Act of the Legislature' $R$ v. Chaytor and others [2010] UKSC 52, paras. 129-133.
} 
is still for Parliament to decide whether its privileges have been infringed and to use its penal powers in cases of contempt. ${ }^{173}$ However, as we saw earlier, the powers of delimitation and interpretation are so closely intertwined that it is by default hard to view them separately; and the smaller the area of exclusive cognisance becomes, the more the distinction between the two powers is rendered meaningless, since an ever narrower 'legal territory' governed exclusively by lex parliamenti leaves almost no room for Parliament to deploy its power of interpretation and application.

That the area governed by lex parliamenti is narrower today than it was at any point since the enactment of the Bill of Rights in 1689 is certain. The courts view privilege of Parliament as being restricted to matters functionally connected to Parliament's constitutional tasks. On the one hand, they assume for themselves a wide discretion to use parliamentary proceedings, for example, to help them with their task of construing statutory legislation and government policy, only limited by the obligation that proceedings in Parliament should not be impeached or questioned'. But even this boundary is today permeable, though not at the discretion of the courts, and only in defamation cases, if individual members of Parliament so desire. Despite this qualification it is clear that, for section 13 cases, the House as a whole has relinquished its power to assert privilege vis-à-vis the courts.

On the other hand, as illustrated by $R v$. Chaytor, there is hardly anything left to the jurisdiction of Parliament beyond what is specifically privileged under Article 9 of the Bill of Rights. Statutory limitations and voluntary relinquishment of the privilege of exclusive cognisance have resulted in wide inroads for lex terrae into what was once reserved to the jurisdiction of the two Houses. This concerns matters of criminal law, but also matters ranging from safety at work to contracts and torts. Only what is intimately related to actual proceedings in Parliament remains subject to exclusive cognisance - and the definition of proceedings is also increasingly narrow, as will be argued later.

We can thus see, in broad terms, that little is left to which the courts have no access, and little which is governed by Parliament alone. But does this mean that the theory of two legal systems, separate and independent from each other, is outdated and that the parliamentary law (and privilege with it) is part of the law of the land? Probably, yes. And this has already been observed by Wittke, writing in 1920, thus after Burdett, Stockdale and Bradlaugh but before Graham-Campbell, Strauss and all later case law: '[c]ourts and Parliament are today in practical agreement that the law of Parliament is part of the law of the land, and there can be no privilege of which the courts cannot take cognizance'. ${ }^{174}$ But he was careful enough to add that if 'champions of a supreme High Court of Parliament, and a separate lex parliamenti, an act which has been committed in Parliament but which constitutes an offence in criminal law and falls within the jurisdiction of the ordinary courts may still also constitute a contempt of Parliament.

174 Wittke 1970, p. 171 
were not wanting throughout the whole of the $19^{\text {th }}$ century, it would be surprising if none could be found in the twentieth, should another crisis arise' ${ }^{175}$

Returning to Chafetz's categorisation, it can be distilled from the body of case law and statute that, not too surprisingly, the current situation is an amalgamation of models (2) and (3), tilted towards the latter. The extent of privilege is fully governed by the courts, which acknowledge that Parliament governs the nature and application of privilege, but only in the very small area left to it. If this categorisation has any practical meaning, it is that the courts will take the views of Parliament into account, and tread carefully in areas of doubt.

Chafetz comes to the conclusion that there are two competing theories of the relationship between lex parliamenti and lex terrae. Either the one is part of the other, or they are in fact separate, but with the courts alone to 'police the boundaries'. ${ }^{176}$ We may not be satisfied, because on this point the British constitution is, in fact, not restlessly clear and none of these theories can be disproven. But this fact hints at a conclusion which is more relevant to the practice of parliamentary privilege, namely that it must be seen as a constitutional convention in itself that both Parliament and the courts are utterly eager to avoid conflict on this point. They must be so in order to evade a dispute to which, as we have seen, there is no definite solution. The notion that the question for the relationship between lex terrae and lex parliamenti is left open as a constitutional custom should be borne in mind when considering the nature and content of today's parliamentary privilege, which will be discussed in the following part.

\section{Parliamentary Privilege Today}

\subsection{The Modern Perception of Privilege}

Today, parliamentary privilege is still regarded as essential to the proper functioning of Parliament. As a principle, the rule that Parliament should therefore enjoy certain powers to govern and protect itself remains therefore relatively intact as a basic feature of British constitutionalism. This is true even though the development towards a more confident demeanour of the courts, statutory incisions (in particular section 13 of the Defamation Act) and the near-complete relinquishment of exclusive cognisance beyond proceedings in Parliament have somewhat pruned the autonomy of the two Houses. That the privileges of Parliament are still important and desirable is widely accepted by doctrine and also evidenced by a variety of statements from the ranks of Parliament, such as the following by the House of Commons' Committee of Privileges: 'Parliamentary Privilege is designed to ensure the proper working of Parliament, and is an essential constitutional safeguard'. ${ }^{177}$

Ibid.

Chafetz 2007, p. 47.

Public Life, First Report of the Committee of Standards in Public Life [Nolan Report], London: HMSO, 1995, Chapter 2, para 91. 
It is today an established principle that privilege does not exist in order to protect and benefit members in their personal capacity but so as to ensure the proper functioning of Parliament as a body. Accordingly, where it happens to protect individual members, it does so in order to safeguard their functioning in their capacity as constituent elements of the respective House. Apart from defamation cases, as has been shown, the principle remains that in general individual members are not able to waive their privilege if they so desire. ${ }^{178}$ After all, the possibility of a waiver could contingently be at odds with the primary aim of privilege, to protect parliament as a corporate body, by infringing on the proper functioning of one of its members.

While the overall recognition of privilege as an important protection mechanism has thus undergone little change, it must be observed that Parliament itself, the courts, as well as legal doctrine have today adopted a more moderate and limited view of the nature of privilege than that which was prevalent in the era of Blackstone. Broadly, two factors may be identified which greatly contribute to this change. ${ }^{179}$

On the one hand, Parliament, and the lower House in particular, now finds itself in a much safer position of power vis-à-vis the Crown than during the middle ages and up until the civil war, from which Parliament emerged as 'sovereign'. Thus, there is now less need to protect members and the House of Commons from intrusions by the Crown. It is a long-standing constitutional convention that the leader of the government of the United Kingdom (the Prime Minister) is recruited from the ranks of the House of Commons rather than the House of Lords. With the current Monarch's role largely reduced to ceremonial functions, and the Lords effectively deprived of much of their former powers, existential clashes between the Crown and Parliament today appear highly unlikely. On the other hand, Parliament, though de iure retaining unlimited legislative power (formally royal assent is required) and wide privilege, has conceded to modern political and societal realities also in its self-conception, accepting in principle the importance of the rule of law, 180 and developing the principle that that privilege 'must not be used for the danger of the commonwealth'. ${ }^{181}$ This contributes to the application of

178 However, prior to the enactment of the Parliamentary Privilege Act 1770, members could waive privilege (i.e. the privilege of freedom from arrest and molestation) in order to attend court, e.g. in a civil suit against them.

179 These two factors are certainly not exhaustive. Factors such as, for example, the general evolution of constitutional legal doctrine towards more emphasis on the rule of law, but also public opinion, triggered by more influential media, certainly contributed to this process as well.

180 This point requires an additional remark for clarification: undoubtedly, the law of privilege as part of lex parliamenti is law. Accordingly, the rule of law is technically not hampered by it. However, the special nature of lex parliamenti as a superseding legal system, limiting the application of ordinary laws to Parliament, may be seen as an exception to the rule of law where the application of the law of the land is limited by it and citizens are deprived of rights they would normally have. See below for a discussion of the applicability of the law to Parliament and its members.

$181 \quad$ Erskine May 2004, p. 93. 
privilege being generally more limited and more in line with contemporary concepts of democracy and the separation of powers than it has been at many instances in the past.

This change of circumstances and in mentality has of course also resulted in considerable changes in the positive law of privilege. For example, several privileges and classes of persons enjoying them have been abolished altogether: the privilege of freedom from arrest no longer accrues to members' servants (quite apart from the fact that the scope of freedom from arrest ratione materiae has been profoundly limited). ${ }^{182}$ As the single most prominent and important privilege and the least curtailed one, the privilege of freedom of speech and parliamentary debate ('proceedings') ex Article 9 of the Bill of Rights 1689 is today the vehicle through which parliamentary immunity is given effect to in Westminster Parliament. Other privileges, such as that of freedom from arrest, freedom of access to Her Majesty or, for the House of Lords, the privilege of Peerage are of very little practical relevance today.

\section{2. $\quad$ Flexibility vs. Legal Certainty}

Before we attempt to analyse the material scope of parliamentary privilege as it stands today, and to determine precisely what rights it confers on Parliament and its members, a word ought to be had on the controversial issue of its flexibility - or potential vagueness.

The fact that the rather extensive privileges of the past have in many ways been pruned back so as to jar with modern circumstances and requirements does not mean that their application has thereby become an easier exercise. As will later be shown through the example of the privileges ex Article 9 of the Bill of Rights 1689, the opposite may be the case where attempts are made to accommodate new legal needs in the old law of privilege.

Much of the difficulty one has to face in determining the exact scope of Westminster parliamentary privilege is due to its being elusive, indefinite, and framed in vague terms. This, however, has frequently been interpreted as being the vehicle of a highly intended flexibility: by keeping privilege indefinite, it is argued that it is less susceptible to dangerous loopholes, remains adaptable to novel situations and is, in consequence, better apt to protect Parliament and its independence. Back in 1939, the Select Committee on the Official Secrets Act has argued in this vein:

182 This was the effect of the enactment of the Parliamentary Privilege Act 1770, which also brought to a much needed end the abusive custom of trade in protections. Note, however, that there is still freedom from arrest for family members of peers by virtue of the privilege of peerage. 
Any attempt to translate [the privileges of Parliament] into precise rules must deprive them of the very quality which renders them adaptable to new and varying conditions, and new or unusual combinations of circumstances, and indeed might have the effect of restricting rather than safe-guarding members' privileges. ${ }^{183}$

This view is still propounded today, ${ }^{184}$ but may well be interpreted as representing the ancient 'Blackstonian paradigm' of privilege, referred to above: Parliament, according to this view, must first and foremost be protected and this need is so important that other aims such as legal certainty must yield. This opinion is a remnant of a time when Parliament was still 'in a fragile stage of its development', and it is questionable whether a more balanced approach, more in line with legal certainty and other requirements of today's legal system, would not be more desirable under today's circumstances. ${ }^{185}$ On the other hand, the advantage of safeguarding the protection of Parliament against all possible novel or 'unusual' threats achieved by such flexibility remains the same today. However, it may be argued that the disadvantages for the practical application of privilege that come with such vagueness have increased, corresponding to the increase in complexity both of the operations of Parliament and the legal system as a whole. Critics of the high degree of uncertainty surrounding privilege assert, for example, that

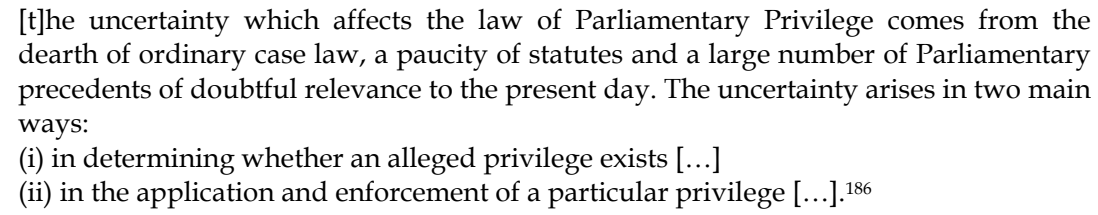

Parliamentary privilege is a body of law which regulates an extremely contentious issue: the immunity of lawmakers from the application of the law. It is conceivable that, where the exact content of this body of law is left in abeyance, this 'can sometimes give an impression of arbitrariness' ${ }^{187}$ It also gives rise to difficulties in upholding, and indeed determining, citizens' rights vis-à-vis (members of) Parliament. At several instances, questions have even arisen as to the compatibility of (absolute) parliamentary privilege with European human rights standards.

The above basically reflects the dilemma between the warranted need for Parliament to be protected and that for citizens to be respected in their rights and to be able to enforce them. The latter point of enforcement brings us, again, to the point of justiciability and the necessary question of which entity - parliament or the courts, is competent to rule on the content and scope of parliamentary privilege. As

183 Report from the Select Committee on the Official Secrets Act (1938-39, HC 101), p. 14.

184 See e.g. Public Life, First Report of the Committee of Standards in Public Life [Nolan Report], London: HMSO, 1995, Chapter 2, para. 87.

185 See supra at 180.

186 Report from the Select Committee on Parliamentary Privilege (1967-68, HC 34), p. 171-172, as quoted in Lock 1998, p. 49.

$187 \quad$ Ibid. 
we have seen, this issue has not, to this date, been finally resolved, so that, theoretically

[t]here may be at any given moment two doctrines of [the justiciability of] privilege, the one held by the Courts, the other by either House, the one to be found in the Law Reports, the other in Hansard; and there is no way of resolving the real point should the conflict arise. ${ }^{188}$

Thus, while today it certainly takes less audacity for the courts to take a strong stance against an assertion of privilege, citizens' access to legal recourse still depends to a large extent on 'the proper anxiety of [Parliament] to confine its own or its members' privilege to the minimum infringement of the liberties of others'. ${ }^{189}$ Whether this is an acceptable situation is debatable. However, cases such as $R v$. Chaytor show not only that the courts have become more assertive vis-à-vis Parliament, but that Parliament itself has displayed little interest in conflict, and has allowed - and even appreciated - the application of the law of the land to almost anything which does not actually constitute proceedings in Parliament. The situation is therefore much less serious than the above seems to suggest.

\subsection{The Modern Privileges: The Law}

Having discussed the overarching question of exclusive cognisance and the evolution and current state of the relationship between the law of Parliament and the law of the land, we will now turn to an analysis of the modern content and scope of parliamentary privilege as far as it confers immunities. This section will individually assess the specific privileges of freedom of speech, debate and proceedings in Parliament (Article 9 of the Bill of Rights), and of freedom from civil arrest. The discussion will be limited to these two essential privileges and the penal powers of Parliament, since the other specific privileges (access to her Majesty, favourable construction) are now redundant. We will omit a detailed discussion of the privilege of the House of Commons to provide for its own constitution, for it would lead us too far from the theme of immunity - much of what is relevant there has already been covered in our examination of exclusive cognisance. ${ }^{190}$

Ibid., p. 53.

A-G of Ceylon v. de Livera (1962) 3 All ER 1066

Note, however, that the right of the House of Commons to regulate their constitution seems very much alive: it was upheld relatively recently in the case of $R v$. Speaker, ex parte McGuiness (3 October 1997, unreported). The Speaker of the Commons had denied two Sinn Féin MPs the right to use the facilities of the Palace of Westminster. They had refused to take the oath of allegiance and therefore had no right to sit in the House. The Northern Ireland High Court declined jurisdiction over the matter, stating that it was 'within the realm of internal arrangements'; see Munro 1999, p. 231. 


\subsubsection{The Privileges ex Article 9 of the Bill of Rights 1689}

The most important component of Westminster parliamentary privilege law is still based on Article 9 of the Bill of Rights 1689. The Bill of Rights is a piece of statutory legislation designed for the Parliament of the 17th century, which, despite having been prima facie the very same institution performing roughly the same tasks, is in many ways hardly comparable with its modern counterpart. Hence, the application and interpretation of Article 9 to the Parliament of the $21^{\text {st }}$ century is difficult from the outset. Not only have the old questions as regards the precise meaning of certain components of Article 9 never really been conclusively resolved, the range of activities of today's Parliament and MPs is also much wider than it was in the $17^{\text {th }}$ century. Accordingly,

\footnotetext{
[t]he modern limits of and application of [proceedings in Parliament], which may have been clear enough to the legislature in the $17^{\text {th }}$ century, are no longer free from uncertainty. ${ }^{191}$
}

In this section we will therefore consider the extent, application and interpretation of the privilege granted by Article 9 of the Bill of Rights 1689 today and consider the legal issues arising therein. Bearing in mind our aim to explore what the exact rights conferred by privilege are, the wording of Article 9 shall be the starting point:

Freedom of speech and debates or proceedings in Parliament ought not to be impeached or questioned in any Court or place out of Parliament.

\subsubsection{Freedom of Speech and Debate}

As is confirmed by Erskine May, it follows from Article 9 of the Bill of Rights that 'a member may state whatever he thinks fit in debate, however offensive it may be to the feelings, or injurious to the character, of individuals; and he is protected by his privilege from any action for libel, as well as from any other question or molestation' ${ }^{192}$ This means that utterances in parliamentary debate as well as other acts which qualify as 'proceedings in Parliament' (see below) are not punishable or otherwise susceptible to legal action in the courts, for want of jurisdiction. Where an action for defamation is brought against a Member of Parliament in relation to an utterance made by him in his House, the courts will not receive the action. ${ }^{193}$ The same is true for other types of action or investigation: Munro cites the case of Duncan Sandys MP, who brought up a matter of national security in a parliamentary question, but refused to disclose the source of his information. When the government wanted to launch an investigation under official secrets legislation, 'the House asserted its privilege in order to avert the threat'. ${ }^{194}$ Further, the

Erskine May 2004, p. 98.

Erskine May 2004, p. 96.

Dillon v. Balfour (1887) 20 LR Ir 600.

HC 146 (1937-38), HC 173 (1937-38); cited in Munro 1999, p. 221 
privileges of Article 9 do not exclusively protect members, but in fact anyone who takes part in 'proceedings', thus also experts or members of the public that are heard by the House or, more likely, by a Committee ${ }^{195}$ (a fact that may be taken as further evidence for the institutional, rather than personal, character of privilege).

It is important to note, however, that Article 9 creates a privilege (similar to all other privileges of Parliament) only with regard to the legal sphere of the nonparliamentary outside world. This means that speech, debates and proceedings are subject to regulations which are part of the law of Parliament, thus mainly the rules of procedure in debate. Hence, they are also punishable, should the case arise, under the parliamentary law of contempt.

Although the text of Article 9 has never been formally amended, the scope of its application has been limited by subsequent legislation; one may thus speak of several implied amendments to Article 9. Erskine May ${ }^{196}$ mentions in this respect the Parliamentary Elections Act 1695,197 the House of Commons (Disqualifications) Act $1801^{198}$ and the Parliamentary Oaths Act 1866,199 all concerning penalties for irregular sitting in the House, as well at the Witnesses Protection Act 1892,200 the Perjury Act $1911^{201}$ and, of course, the Defamation Act 1996.202 All of these statutes derogate from, and therefore impliedly amend, Article 9 to the effect that certain proceedings may indeed be the subject of scrutiny by the courts. Hence, the areas covered by these statutes are not privileged. The same is true where statutes explicitly provide that they be applied to Parliament, as is the case in employment law pertaining to staff (other than members) of both Houses under the Employment Act $1990 .{ }^{203}$

Apart from these limitations, the immunity from application of the ordinary law conferred on Parliament by Article 9 seems, at first glance, quite wide. However it also quickly becomes clear that determining the exact extent of this immunity depends on questions of definition which turn out to be difficult.

\subsubsection{Proceedings in Parliament}

It is difficult to draw a line between what qualifies as a 'proceeding in parliament' and what does not. In order to formulate an exact idea of what is a proceeding relating to privilege, several questions have to be answered: do we have to take 'proceedings in parliament' as a spatial notion? If so, is there an additional functional requirement for an act or event to relate in some way to the constitutional tasks of Parliament in order to qualify as a proceeding? Further, while it may be

Goffin v. Donelly (1881) 6 QBD 307.

Erskine May 2004, p. 115

1695 c25 7 \& 8 Will. 3.

1801 c52 41 Geo. 3.

1866 c19 29 \& 30 Vict.

1892 c64 55 \& 56 Vict.

1911 c6 1 \& 2 Geo. 5.

1996 c31.

1990 c38. 
reasonably clear what a court is, what is a 'place out of parliament'? Does this cover public debate or media publications? What exactly is meant by the terms 'impeached' and 'questioned'? This might be very relevant where a proceeding in parliament, for example, a speech given there, could serve as evidence in court. And finally, can we rightfully infer any qualification of the privilege from the wording of the article, in that speech, debate, and proceedings ought not to be impeached or questioned - as opposed to must not? Lingering around these issues is, of course, the question if and how the antiquity of this statute should be considered in its interpretation.

Thus far, there is no statutory definition of the term 'proceedings in parliament', nor has complete agreement been reached otherwise. There has been much debate as to whether the term 'proceedings in parliament' actually covers every event or act that takes place in the Palace of Westminster. At the same time, it is not inconceivable in modern times that events or acts that do not take place in the Parliament building could qualify as proceedings in parliament because of their close connection with the business of Parliament or the parliamentary work of a member. Erskine May states that only 'a broad description' can be given, while 'comprehensive lines of decision' as to what does and what does not constitute a proceeding in parliament have not emerged. ${ }^{204}$ The Treatise thus arrives at a summary definition which leaves much room for uncertainty: as a 'technical Parliamentary term', proceedings are 'some formal action, usually a decision, taken by the House in its collective capacity'. By extension, 'proceedings' should include the various forms of business, the necessary processes and the actors which play a part in such action. ${ }^{205}$ This seems to make reasonably clear that not everything becomes a proceeding in parliament just because it happens to occur on the premises of Parliament, that is to say, at the Palace of Westminster. However, diverging views adopted in case law illustrate that this is basically the smallest common denominator, beyond which no consensus can be reached.

In Rost v. Edwards it has been judicially acknowledged that a definition cannot be achieved. ${ }^{206}$ The case brought up the question of whether or not the Register of Members' Interests and the procedure relating to it is part of the 'proceedings of parliament'. Popplewell J was of the Opinion that '[i]t is clearly not possible to arrive at an exhaustive definition' 207 of 'proceedings in parliament'. Having to deliver a judgment, the court decided that the Register of Members' Interests does not qualify as a proceeding. This decision was taken, however, on the basis of analogies to statutory definitions in other Commonwealth jurisdictions ${ }^{208}$ and, one might suggest, to a certain extent arbitrarily. Popplewell J reiterated the

Erskine May 2004, p. 111

Ibid.

Rost v Edwards (1990) 2 QB 460.

Ibid., at 478 .

Ibid., at 477. Section 16(2) of Australia's Parliamentary Privileges Act 1986 defines 'Proceedings in Parliament' as 'all words spoken and acts done in the course of, or for purposes of or incidental to, the transacting of the business of the House or of a Committee $[\ldots]^{\prime} ;$ ibid., at 477 . 
impossibility of arriving at a conclusive definition by citing Lord Pearce: 'I do not know, I only feel' ${ }^{209}$ As a consequence, the Register of Members' Interests could be used as evidence in court. Leopold cites the Canadian case of $R$. $v$ Bunting 210 in which it was ruled that 'anything [a member] might say or do within the scope of his duties in the course of Parliamentary business' 211 would be subject to privilege, a view that has at the time (1939) been accepted by the Select Committee on the Official Secrets Act. This very wide interpretation of Article 9 was, however, later not consistently upheld, either by Parliament or by the courts.

It is clear that for this issue to be resolved, a statutory definition would have to be adopted. This has been proposed at various instances. In 1999 the Joint Committee on Parliamentary Privilege pondered a wide range of individual acts, considering whether they should or should not be covered by the term 'proceedings in parliament'. Finally, the Committee called for a statutory definition:

129. The Joint Committee recommends the enactment of a definition on the following lines:

(1) For the purposes of Article 9 of the Bill of Rights 1689 'proceedings in Parliament' means all words spoken and acts done in the course of, or for the purposes of, or necessarily incidental to, transacting the business of either House of Parliament or of a committee.

(2) Without limiting (1), this includes:

(a) the giving of evidence before a House or a committee or an officer appointed by a House to receive such evidence

(b) the presentation or submission of a document to a House or a committee or an officer appointed by a House to receive it, once the document is accepted

(c) the preparation of a document for the purposes of transacting the business of a House or a committee, provided any drafts, notes, advice or the like are not circulated more widely than is reasonable for the purposes of preparation

(d) the formulation, making or publication of a document by a House or a committee

(e) the maintenance of any register of the interests of the members of a House and any other register of interests prescribed by resolution of a House.

(3) A 'committee' means a committee appointed by either House or a joint committee appointed by both Houses of Parliament and includes a sub-committee.

(4) A document includes any disc, tape or device in which data are embodied so as to be capable of being reproduced there from. ${ }^{212}$

Ibid., at 478 .

R. v. Bunting (1885) 7 OR 524 (Ont. C.A.).

Leopold 1998, p. 73.

Joint Committee on Parliamentary Privilege, First Report, 1999, HL 43-I, HC 214-I para. 129.

See also Annex B to this report, which contains several alternative proposals for a statutory definition of 'proceedings in Parliament' by the Joint Committee on the publication of proceedings in Parliament, Second Report (1969-1970) HL 109, HC 261, paras. 27-30. While the 
This or a similar definition, if adopted, would serve to clarify many of the questions relating to the interpretation of 'proceedings in parliament'. In particular the recommended introduction of a test as to whether something is 'necessarily incidental to' the work of Parliament might be of help, even though the phrase is still very broad. It would, for instance, simplify the task of answering the question whether different types of correspondence or other communication are considered to be covered by privilege as proceedings by introducing a relatively clear and binding functional criterion. That this is desirable is evidenced by the fact that both Parliament and the courts have applied a similar rationale in the past when determining the status of correspondence: where a minister invites a parliamentarian to discuss with him a matter that has been brought up in Parliament, the ensuing talk or correspondence is privileged.213 Defamatory statements about a person's former spouse in correspondence addressed to MPs do not fall under a privilege even if the letters concerned have been posted from the premises of the Palace of Westminster. ${ }^{214}$ Munro argues that, in this vein 'even unsolicited correspondence is covered [as a proceeding], if it is immediately related to a question or motion already tabled or a pending debate'.215 The problem of privilege with regard to correspondence becomes more difficult where the connection of an act, utterance or document to the 'core' parliamentary work is less evident (and less necessarily incidental, as it were). In Beach $v$. Freeson, ${ }^{216}$ it was held that letters of an MP, in which he complained on behalf of constituents to the Law Society about a law firm in his constituency, were protected by qualified privilege. ${ }^{217}$ This was the case even though the correspondence in question did decidedly not qualify as 'proceedings in parliament', but was nonetheless a result of the member's pursuit of his duties as a representative of his constituency. In the presence of a statutory definition, as recommended by the Joint Committee, it supposedly would (narrowly) have passed the test of being necessarily incidental to the parliamentary work.

However, an example of a question that would not be resolved - or not satisfactorily be resolved - even by the introduction of a statutory definition of 'proceedings', is whether courts would be allowed to conduct procedures of judicial review of decisions or of ministers (which is in principle possible) where such decisions, or the communication thereof, are effected by speech in Parliament, as is often the case. After all, the decision itself need not be directly related to parliamentary business.

application of the definitions then proposed was intended to be limited to cases involving the publication of Parliamentary materials, the definitions themselves were more detailed than the one quoted here.

213 This was decided by the Speaker of the Commons, see Munro 1999, p. 222, citing 591 HC Official Report (5 $5^{\text {th }}$ series) 208.

Rivlin v. Bilainkin (1953) 1 QB 485.

Munro 1999, p. 223.

Beach v. Freeson (1972) 1 QB 14.

Privilege which can be challenged by proving malice. This type of privilege applies also to publications of parliamentary debates. These are protected by qualified privilege if accurate or wrong without malice, but not in case of malicious misrepresentation. 
Another issue which would remain unresolved by the definition proposed by the Joint Committee is the question whether criminal acts could possibly be under a privilege, if committed in the course of proceedings in Parliament. Since the phrase 'in the course of' does not explicitly limit the scope of privilege to such acts which bear a thematic connection to the parliamentary business in progress (in which case it would hardly be conceivable how any crime could be covered by the definition), it remains theoretically possible that Article 9 would put criminal acts (other than speech acts) under privilege. This position has historically been rejected in Bradlaugh v. Gossett, ${ }^{218}$ with reference to Elliot's case, ${ }^{219}$ but was apparently accepted by the Commons in 1988, when Ron Brown MP 'damaged the mace in the course of a heated debate, and failed to apologise in the way expected' ${ }^{220}$ In that case, the issue was not left to the courts, but was dealt with by means of the penal powers of the House. Of course, one can see that this instance should not be overestimated as a precedent for criminal acts being under privilege and therefore not subject to ordinary judicial procedure; while breaking the mace admittedly can be seen as a criminal act, it is still so intimately related to Parliament's inner dealings, and so utterly unimportant to the outside world and the general interest of justice, that it may constitute a rather minor exception without the value of a precedent.

More recently, the UK Supreme Court, in its important decision in $R v$. Chaytor and others 221 (see above), was confronted with the question whether the act of submitting claims for expenses (as well as the claims forms themselves and the administrative processing thereof) falls under the definition of proceedings in Parliament. In order to answer this question, the Court had to determine whether proceedings in Parliament are defined by a functional criterion. If this were the case, something would have to be an immediate and necessary part of the constitutional functions of Parliament in order to be protected under Article 9 of the Bill of Rights.

The Court followed a number of leads: First, it conducted an extensive review of case law, citing Elliot's case, Bradlaugh v. Gossett, Pepper v. Hart and Prebble v. TVNZ. While all these cases point in the direction of a wide interpretation of proceedings in Parliament, they all relate to matters which are very obviously part of Parliament's core business, in that they mainly concern utterances in parliamentary debates. 222

Second, the Court examined corruption cases.223 The difficulty in these cases is that the act of taking or giving a bribe, or that of conspiring to deceive Parliament, is

\footnotetext{
218 Erskine May (2004, p. 117) warns that this statement should be taken to refer to criminal acts, as distinguished from criminal speech.

219 R. v. Elliot, Hollis and Valentine [1629] 3 St. Tr. 294. See also Erskine May 2004, p. 81. In this case, the Speaker of the Commons had been physically restrained in this chair so as to prevent him from adjourning the session of the House. The responsible members were arrested and sentenced for seditious libel as well as for the attack on the speaker. Although the judgment was later reversed under a writ of error, it was not denied that physical acts of violence by members in the House are not privileged.

$220 \quad$ Leopold 1998, p. 74.

$221 \quad R v$. Chaytor and others [2010] UKSC 52

222 Ibid., paras. 27-32.

$223 \quad$ Ibid., paras. 33-46.
} 
itself never part of proceedings, while it clearly has as its objective to influence proceedings. The Court cites the case Ex parte Wason of 1869,224 in which it was held that no prosecution could be based on untrue statements made in the House of Lords in the course of a conspiracy to deceive the House, because 'the motives or intentions of members of either House cannot be inquired into by criminal proceedings with respect to anything they might do or say in the House'. However, the Court also refers to the Canadian case $R v$. Bunting, ${ }^{225}$ in which conspiracy to influence a vote in Parliament by bribery was treated as an offence at common law. In the United States case US v. Brewster, 226 the US Supreme Court followed the teleological argument that the aim of freedom of debate was to protect the legislator as a body, not the individual congressman, and that 'depriving the judiciary of the power to punish bribery of Members of Congress is unlikely to enhance legislative independence'. Still, the Supreme Court recognises that the issue is difficult: it cites the Indian case Rao v. State, ${ }^{227}$ in which it was held that MPs could not be prosecuted for bribery related to voting in Parliament, because that would require judicial review of their voting behaviour. Lastly, the Supreme Court considers $R v$. Greenway. In this case of 1992, the defendant, Mr. Greenway MP, tried to invoke parliamentary privilege ex Article 9 of the Bill of Rights against his prosecution for bribery. However, the court in that case rejected this defence. Buckley J held that 'If [...] a bribe is given and taken by a member of Parliament, to use his position dishonestly [...], the crime is complete. It owes nothing to any speech, debate or proceedings in Parliament'. He also based his decision against Greenway's claim to privilege on the observation that immunity from prosecution for corruption is 'an unacceptable proposition at the present time' and that a body like the House's Committee of privileges would not be well-equipped to try a member for corruption.

From the above, the Supreme Court infers that the protection of Article 9 of the Bill of Rights 1689 is to be interpreted narrowly - yes, proceedings in Parliament remain off-limits to the courts, but only actual parliamentary debates, votes and decisions are to be considered as proceedings. Lord Phillips, author of the majority Opinion in $R v$. Chaytor, clearly assumes a functional criterion for the definition of proceedings in Parliament:

[...] the principal matter to which article 9 is directed is freedom of speech and debate in the House of Parliament and in parliamentary committees. This is where the core or essential business of Parliament takes place. In considering whether actions outside the House and committees fall within parliamentary proceedings because of their connection to them, it is necessary to consider the nature of that connection and whether, if such actions do not enjoy privilege, this is likely to impact adversely the core or essential business of Parliament. ${ }^{228}$ [Emphasis added.]

$224 \quad$ Ex parte Wason (1869) LR 4 QB 573.

$225 \quad R v$. Bunting (1885) 7 OR 524

226 US v. Brewster (1972) 408 US 501

227 Rao v. State (1998) 1 SCJ 529.

${ }_{228} \quad R$ v. Chaytor and others [2010] UKSC 52, para. 47. 
In the following paragraph of the judgment, Lord Phillips draws the obvious conclusion for the case of submitting fraudulent expenses claims:

[i]f this approach is adopted, the submission of claims forms for allowances and expenses does not qualify for the protection of privilege. Scrutiny of claims by the courts will have no adverse impact on the core or essential business of Parliament. It will not inhibit debate or freedom of speech. Indeed it will not inhibit any of the varied activities in which Members of Parliament indulge that bear in one way or another on their parliamentary duties. The only thing it will inhibit is the making of dishonest claims. $^{229}$

Finally, the Court acknowledges that this view is consistent with that expressed by the Joint Committee on parliamentary privilege in its 1999 report, by the Parliamentary Commissioner for Standards and by the Speaker of the Commons.

Does $R v$. Chaytor finally bring the old quest for a definition of 'proceedings in Parliament' to an end? Probably not, as the judgment still leaves room for 'actions outside the House' and 'committees fall within parliamentary proceedings because of their connection to them'. However, this is an almost negligible test of uncertainty: there seems to be consensus that parliamentary proceedings are those things which form or are closely connected to the 'core or essential business of Parliament, which consists of collective deliberation and decision making' ${ }^{230}$ This definition is perhaps not a panacea for all possible cases, but it limits the room for interpretative speculation considerably and, more importantly, it seems to introduce a workable judicial test. Where, in future cases, a defendant claims privilege ex Article 9 in his defence, he will need to convince the court that the subject matter of his case touches the very core functions of Parliament - in short, that it touches upon freedom of speech.

Hence, we can conclude that a narrow interpretation of Article 9 of the Bill of Rights is now widely accepted, and that the hinge of this definition is a functional criterion. Criminal acts (other than criminal speech) therefore cannot constitute proceedings in Parliament, unless they relate so directly to parliamentary debate that they must be considered part of it (think of MP Ron Brown damaging the mace without due apology). Equally, acts and documents relating merely to the administration of the Houses or the administrative concerns of members will not constitute proceedings.

\subsubsection{3. 'Questioned'}

Whereas the term 'impeached' may be regarded as relatively clear, that does not hold true for the term 'questioned' in Article 9. The main scenario in which 'questioning' is at issue is where it is intended to use parliamentary proceedings as evidence in court. Since Pepper v. Hart and Prebble v. Television New Zealand, the rule has been that, on the one hand, proceedings in Parliament may be used by judges to 
help them interpret statutory provisions, provided the proceedings would in no way be criticised. They may also be used by courts in proceedings of judicial review of government decisions or other administrative acts. ${ }^{231}$ Munro describes such usage as 'benign or neutral, rather than adverse'. 232 When looking for a definition of the term 'questioned' in Prebble, the Privy Council consulted section 16(3) of the Australian Parliamentary Privileges Act 1987, which says that:

\footnotetext{
[i]t is not lawful for evidence to be tendered or received, questions asked or statements, submissions or comments made, concerning proceedings in Parliament, by way of, or for the purpose of:

(a) questioning or relying on the truth, motive, intention or good faith of anything forming part of those proceedings in Parliament;

(b) otherwise questioning or establishing the credibility, motive, intention or good faith of any person; or

(c) drawing, or inviting the drawing of, inferences or conclusions wholly or partly from anything forming part of those proceedings in Parliament.
}

Whereas this provision is not wholly suitable as a definition of the word 'questioned' proper (as it employs the word several times itself), it does provide us with good guidance as to what may not be done with parliamentary proceedings in Court. In Prebble, the Privy Council agreed with the Australian definition. Proceedings may thus not be brought as evidence where there is any chance that what has been said or done in Parliament might be attacked, argued against, doubted or in any other way questioned. In the UK, this is of course only true as long as there is no waiver of parliamentary privilege pursuant to section 13 of the Defamation Act 1996. ${ }^{233}$ Where the prohibition to 'question' makes it impossible to determine the case, court proceedings have to be stayed. As has been mentioned previously, this situation could potentially leave MPs without a remedy where they are unable to defend themselves, or bring an action, since they would have to rely on parliamentary proceedings.

Whereas the usage of proceedings in Parliament as evidence is certainly the most common instance at which the interpretation of the term 'questioned' is at issue, one may also ask whether privilege protects proceedings from being questioned in other contexts. For example, parliamentary proceedings are very frequently the object of highly critical comment in the media which could well amount to 'questioning' if the term were to be interpreted broadly. However, Parliament today seems to favour a much narrower interpretation which does not stand in the way even of critical 'questioning' or commenting. This is still subject to the conditions that, first, proceedings are not maliciously misrepresented and,

231 Examples for such usage can be found in $R v$. Secretary of State for the Home Department, ex parte Brind (1991) 1 AC 696 and $R v$. Secretary of State for the Home Department, ex parte Fire Brigades Union (1995) 2 AC 513.

232 Munro 1999, p. 224

233 That in case of a waiver the 'questioning' may indeed amount to a challenge of the contents of a statement has been confirmed in Hamilton v. Al Fayed (2001) 1 AC 395 (H.L.). 
second, that the 'questioning' does not (potentially) entail any legal effects (which can be the case where proceedings are challenged in court). ${ }^{234}$

One may conclude that the term 'questioned', though perhaps equally in need of statutory definition, is easier to apply than 'proceedings'. The body of case law and statute which has evolved since Pepper is still somewhat imperfect, and an entirely satisfactory answer has not yet been found in UK law. However, such case law has brought quite an insight: the mere usage of proceedings is not necessarily in breach of privilege. Citing Hansard in court for the purpose of proving that a certain statement has been made, or a certain 'proceeding' has taken place in Parliament, is not 'questioning' in the sense of Article 9 of the Bill of Rights. To a certain extent, such a statement may also be understood, that is, the courts may take cognisance of its meaning, for how else could it otherwise help them to interpret statutory provisions or identify government policy? This is more debatable than it may seem at first glance because it takes away from Parliament, at least to a certain extent, the interpretative authority over its own word. What if, say, the House of Commons came to the conclusion that a court had profoundly misinterpreted a statement made in one of its debates? Clearly, even if no such error occurred, the taking into consideration of parliamentary statements in the interpretation of statutes already necessarily amounts to 'drawing inferences or a conclusion' which is unlawful under Australian law. We may therefore see, also in the seemingly harmless usage of proceedings, an intrusion into the proceedings in Parliament. The law as it stands does not seem to recognise this as a breach of privilege. Lacking a statutory definition, however, the boundary between lawful usage and prohibited questioning of parliamentary proceedings remains thin. Admittedly, it is by no means certain that a statutory definition would be able to solve this problem.

\subsubsection{4. 'Place Out of Parliament'}

The term 'place out of Parliament' is another example of how inadequate the wording of Article 9, drafted in 1689, is with regard to present-day circumstances. The Joint Committee on Parliamentary Privilege has called it 'another obscure expression of uncertain meaning'. ${ }^{235}$ The Joint Committee went on to recognise, without any doubt, that:

[t]o read the phrase as meaning literally anywhere outside Parliament would be absurd. It would prevent the public and the media from freely discussing and criticising proceedings in Parliament. That cannot be right, and this meaning has never been suggested. ${ }^{236}$

Whereas in the $17^{\text {th }}$ century the meaning of 'any place out of Parliament' may not have caused much difficulty (since a spatial or geographical reading of the phrase

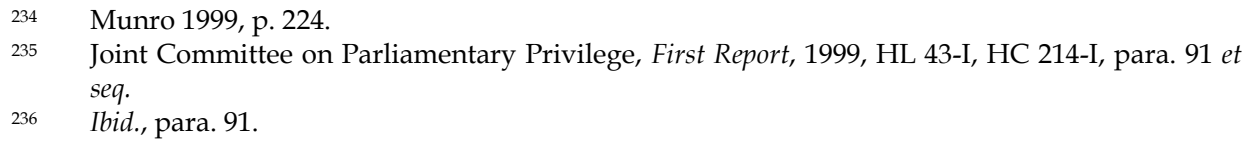


could have been conceivable), it now has to face questions like, for instance, whether or not the media and media publications are 'places'. The same question can also be asked about independent review commissions, even where they are appointed by the government, for evidently being 'independent' means that reviews are explicitly not conducted by Parliament. Hence, though ordered by Parliament, review commissions will likely operate out of Parliament.

With regard to the media, the situation has not been finally resolved; however, Parliament has at various instances made clear that it will not intervene where media coverage of proceedings in Parliament is done accurately. In cases of misrepresentations of parliamentary proceedings, especially where done wilfully, it is very likely that Parliament would treat them as breaches of privilege, applying sanctions under the law of contempt.

As for the case of independent review commissions, Leopold refers to the inquiry into overseas weapons sales to Iraq led by Sir Richard Scott. Sir Richard was a Lord Justice and, in his capacity of leader of the inquiry, he heavily criticised several statements made in Parliament. Had privilege been applied strictly, he would not have been able to discharge his task which, after all, included the 'questioning' of what had happened in Parliament - otherwise his task would have been meaningless. ${ }^{237}$ The Joint Committee on Parliamentary Privilege found it dissatisfactory that, in its view, statutory tribunals under the Tribunals of Enquiry (Evidence) Act 1921, 238 being sufficiently similar to a court, would qualify as 'places out of Parliament' whereas Scott's non-statutory independent inquiry did not. The Committee recommended, therefore, that the term 'place out of Parliament' be defined by statute,

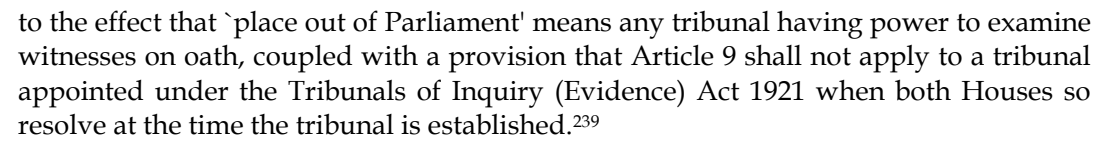
witnesses on oath, coupled with a provision that Article 9 shall not apply to a tribunal appointed under the Tribunals of Inquiry (Evidence) Act 1921 when both Houses so resolve at the time the tribunal is established. ${ }^{239}$

Erskine May notes that in 2003, members of the Foreign Affairs Committee voluntarily gave evidence to a non-statutory inquiry, which did not incite a discussion with regard to privilege. c.12) which regulates the work and procedures of inquiry panels set up by the government. With regard to parliamentary privilege, the problems which the Joint Committee saw under the Act of 1921 would also arise under the new Act. Interestingly, S. 22(1) of the Inquiries Act 2005 provides that a person may not be required to produce evidence or documents 'if (a) he could not be required to do so if the proceedings of the inquiry were civil proceedings in a court in the relevant part of the United Kingdom, or (b) the requirement would be incompatible with a Community obligation'. According to the explanatory memorandum, it follows from S. 22(1) that 'a person will be able to refuse to provide evidence [...] because it relates to what has happened in Parliament'. Joint Committee on Parliamentary Privilege, First Report, 1999, HL 43-I, HC 214-I, para. 96. 
The term 'place out of Parliament' has not yet been the subject of case law, so that we cannot attempt to draw a definition from judicial decisions. What seems sufficiently clear, however, is that 'place' should not be read strictly, and certainly not as a spatial notion, limiting 'Parliament' to the Palace of Westminster. In practice, Parliament itself has already conceded wide freedoms to criticise Parliament to the media, in the interest of public debate. It is clear that statutory as well as non-statutory inquiries, where they are officially sanctioned by Parliament, should also not be held to be places in which parliamentary proceedings must not be impeached or questioned, for this would make it impossible for them to do justice to their assignment.

\subsubsection{Recent Developments and the Future of the Article 9 Privileges}

Since the publication of the Joint Committee's report in 1999, no legislative action has taken place concerning privilege. It is therefore at this point utterly difficult to foresee future developments. However, at this point, in early 2013, it must be assumed that new legislation is imminent, as parliamentary privilege has received a great amount of - largely unfavourable - public attention in recent years.

Even before the parliamentary expenses scandal of 2009 and the subsequent Supreme Court judgment in 2010, privilege came under the spotlight in the course of what has become known as the Damian Green affair in late 2008. This affair unfolded after the Metropolitan Police, invited by the Cabinet Office, had entered into an investigation of leaks of secret material to the press. Following the arrest of a Home Office official who had supposedly given the material to Damian Green MP, who in turn had leaked it to the press, a court had issued a search warrant for Mr. Green's home and constituency office, but not for his parliamentary office. The police then asked for permission from the Sergeant at Arms to search the parliamentary office. The Sergeant at Arms was informed by the Clerk of the House that he had the delegated authority to permit the search, but only if the Speaker agreed. The Sergeant gave her consent to the police and informed the Speaker, who wrongly believed that the police had a warrant. During the search, a variety of documents were seized that were later identified as being protected under privilege as parliamentary proceedings and had to be returned. Damian Green was arrested. However, criminal charges against him under official secrets legislation were eventually dropped.

After this unprecedented search of a member's parliamentary office by the police without a warrant, the seizure of privilege-protected parliamentary documents from that office and the arrest of a member of the Commons, the House established a Committee on Issue of Privilege, whose report was published on 26 March 2010.240 Along with a review of the internal processes of the House, the terms of reference assigned the Committee with the task 'to consider any matter relating 
to privilege arising from the police operation, and to make recommendations for the future. '

The Damian Green affair brought to light, on the one hand, that the rules on privilege, especially as to the definition of proceedings in Parliament and those governing the procedure which has to be followed during investigation on the parliamentary premises, are as of yet unclear, and that it is not evident that the vagueness (or flexibility) of these rules constitutes an advantage where a detailed interpretation is needed. In the Damian Green episode it was utterly unclear whether privilege would prohibit a search, or under which conditions it would not prohibit it, since the situation was novel. ${ }^{241}$ What was also shown, on the other hand, is that another major disadvantage of unclear rules lies in the ignorance concerning privilege on the parts of members, House officials and the government, the police and the judiciary. In the minutes of evidence to the report, the Clerk of the House speaks about 'the slightly mysterious term of "exclusive cognisance'" 242 when reporting on the powers of the Speaker and those of the officials who are not members. This, and the failure of the Sergeant and the Speaker to act in a coordinated way when confronted with the request of the police for permission to search Mr. Green's office, suggests that putting privilege on a statutory footing might be a desirable step, despite the unease with which this idea is frequently met.

In its conclusion, the Committee on Issue of Privilege states that it does 'not consider that anything the police did amounted to a breach of privilege or a contempt of the House but [that] the conduct of the police in this matter clearly fell below acceptable standards $[\ldots]^{\prime} .{ }^{243}$ Then, however, the recommendations of the Committee stop short of demanding the enactment of new statutory legislation:

\begin{abstract}
As we have indicated, there are a number of issues connected with parliamentary privilege which deserve careful consideration. It would in our view be a mistake for Parliament to legislate in haste or to address only one aspect of the multi-faceted relationship between liberty, Parliament and the law. While we have no unanimous conclusion on the wisdom or necessity of legislating on parliamentary privilege, we agree in recommending that before any Government Bill on the subject was introduced it would be highly desirable for the whole question to be addressed in the round by a special joint committee drawn from both Houses. Before setting out to define and limit parliamentary privilege in statute, there needs to be a comprehensive review of how that privilege affects the work and responsibilities of an MP in the twenty-first century. [Emphasis original.] ]24
\end{abstract}

The report once again underlines the need to clarify the exact nature and content of parliamentary privilege, as in novel situations (those in which the 'flexibility' of privilege law is considered particularly useful by its supporters) it will often be the case that nobody knows the exact scope of privilege and there remains a high degree of uncertainty as to the procedural aspects of its application.

241 In para. 143 of the report, the committee acknowledged that the question had not been mentioned at all in the Joint Committee report of 1999.

Ibid. Evidence 30, question 223.

Ibid., para. 30.

Ibid., para. 169. 
After the Damian Green affair and the parliamentary expenses scandal, legislation on privilege has been expected. The Queen's speech of 2010 stated that 'A draft Bill will be published on reforming parliamentary privilege'. ${ }^{245}$ The deputy leader of the House of Commons announced in December 2011 that consultations on the desirability of legislation would be held before the end of the 2012/2013 session. ${ }^{246}$ While it seems now that the introduction of a privilege bill during this session is unlikely, ${ }^{247}$ the government has indeed published a Green Paper on parliamentary privilege in which it discusses the pertinent issues, presents the current state of the law and raises a number of questions for consultation with Parliament and the wider public. ${ }^{248}$ For instance, the paper acknowledges - with reference to the Damian Green affair - the sometimes ambiguous meaning of 'proceedings in Parliament' and asks whether there should be a statutory definition of this phrase. It also asks whether proceedings should be allowed to be used as evidence in court, whether section 13 of the Defamation Act should be repealed, and whether, following the Chaytor judgment, the extent of Parliament's privilege to organise its internal affairs should be clarified by statute.

Following the advice of the Committee on Issue of Privilege quoted above, the government Green Paper does not take a hasty, one-sided stance on the question of whether or not legislation is due. Rather, the paper attempts a holistic review of all issues arising in the context of privilege. Thus, instead of making concrete proposals, the paper mainly discusses the background of these issues and the presumed advantages and disadvantages of statutory regulation. The government acknowledges the recommendations for legislation made by the Joint Committee in 1999. It does, however, not believe that the case has been made for a comprehensive codification of privilege: '[...] in general the Government does not see enough evidence of problems in practice to justify such a significant exercise, which would inevitably have other consequences that may not be currently foreseen'. ${ }^{249}$ It adds that, "notwithstanding the discrete areas discussed in this paper where there may be a clear case for legislative change, the boundaries of parliamentary privilege have for the most part been very clear, and its operation has not been sufficiently problematic to justify such a radical departure from the UK's basic constitutional underpinning' ${ }^{250}$ In particular, the paper does not appear to call for a statutory definition of the elements of Article 9 of the Bill of Rights. The areas where the government does propose legislation relate to:

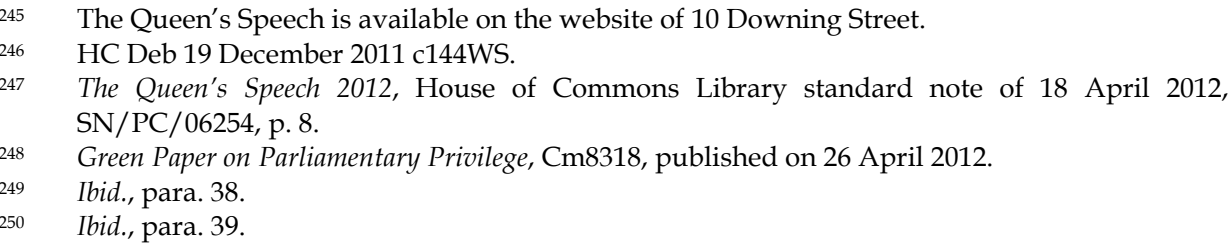


Parliamentary Privilege in the United Kingdom

- $\quad$ the use of proceedings in Parliament as evidence in criminal proceedings;

- voting rights for lay members of the House of Commons committee on standards;

- $\quad$ the reporting of proceedings in Parliament and the Parliamentary Papers Act 1840 .

The second of these points is of minor relevance to this study. ${ }^{251}$ Following the expenses scandal of 2009, the Committee on Standards in Public Life (CSPL) had made a recommendation, among others, that there should be at least two lay members who had never been parliamentarians on the standards and privileges committee (CSP). ${ }^{252}$ However, there were doubts as to whether committee proceedings in which lay members take part would still be protected by parliamentary privilege.253 In addition, the House of Commons Procedure Committee recommended that the Committee on Standards and Privileges be split in two separate committees, and that lay members with voting rights should only sit on a Committee on Standards. ${ }^{254}$ The split has in the meantime been effected. The Green Paper contains a draft clause which allows the House to grant lay members of the Committee on Standards full voting rights without prejudice to the applicability of privilege to the Committee's proceedings.

The first and second points on which the government proposes legislation are more interesting for our purpose. The government considers that it is wrong in principle to deny the courts access to any relevant evidence when the alleged act is serious enough to have been recognised as a criminal offence' ${ }^{255}$ Hence, it proposes to allow the use of proceedings, otherwise privileged by virtue of Article 9 of the Bill of Rights, as evidence in criminal proceedings. These need not necessarily relate to criminal acts committed in proceedings or even by a participant therein; the questioning of proceedings in court would be allowed as long as they contain evidence relating to the alleged criminal act. Section 1(1) of the government's draft clause on the matter reads as follows:

(1) No enactment or rule of law preventing the freedom of speech and debates or proceedings in Parliament being impeached or questioned in any court or place out of Parliament is to prevent any evidence being admissible in proceedings for an offence. 256

However, subsequent sub-sections make this permission subject to a number of exceptions in the form of a list of offences to which it would not apply. According to the Green Paper, these are offences 'related closely to the principal reason for the

Green Paper on Parliamentary Privilege, Cm8318, published on 26 April 2012, p. 59

252 Committee on standards in public life, 12 ${ }^{\text {th }}$ report, MPs' Expenses and Allowances, 2009, recommendation 51.

253 Green Paper on Parliamentary Privilege, Cm8318, published on 26 April 2012, paras. 236-237.

254 Procedure committee, $6^{\text {th }}$ report 2010-2012, Lay Membership of the Committee on Standards and Privileges, HC 1606, para. 53.

255 Green Paper on Parliamentary Privilege, Cm8318, published on 26 April 2012, para. 95.

$256 \quad$ Ibid., p. 37-41. 
protection of privilege, i.e. the protection of freedom of speech and debate in Parliament'. ${ }^{257}$ The list of offences in relation to which proceedings could not be used as evidence contains the common law offence of misconduct in public office as well as most of the offences listed in the Official Secrets Act 2000 and the Public Order Act 1986. According to an analysis published by the House of Commons Library, these exceptions would play a role where an MP (for example as a defendant in court) wants to refer to material 'which might be in breach of the law' ${ }^{258}$ Other offences listed as exceptions mainly relate to data protection law and serve the protection of persons who provide members of Parliament with information. ${ }^{259}$

Interestingly, the Green Paper discussed the danger of a 'chilling effect' on free speech in Parliament which might result from allowing the courts to use (and 'question'!) parliamentary proceedings if participants in those proceedings would be prevented from making a contribution due to fear that it might later be examined in court. The government acknowledges this danger but also contends that enacting the draft clauses (including the list of exceptions) would make it possible to balance two competing requirements - ensuring that parliamentary privilege cannot be used to evade the reach of the courts where criminality is suspected, while protecting the right of free speech and debate in Parliament. ${ }^{260}$ Moreover, privilege would still protect any participants in parliamentary proceedings - not only members - from civil actions, for example, for defamation.

Significantly, the government does not propose the repeal, amendment or replacement of section 13 of the Defamation Act 1996. If briefly addresses the criticism which the possibility of a personal waiver has received, but also points out the disadvantages of alternative solutions: repealing it would, of course, bring back the problems which it was meant to remedy. Giving the power of waiver to the House, a committee or the Speaker instead of the individual member could have a great and chilling effect on free speech, as a member could not be certain whether privilege would be waived. And allowing the House to waive a member's privilege only under the condition that he would not incur legal liability would deprive the waiver of all use. Observing that no use has been made of section 13 since Hamilton $v$. Al Fayed, the government does not offer a solution, and apparently doubts that one is needed. ${ }^{261}$

This is particularly interesting in the light of a Defamation Bill which the government introduced in the House of Commons in May 2012. ${ }^{262}$ It has already passed through three readings in the Commons and is currently being debated in the Lords. ${ }^{263}$ The Bill does not make any amendments to section 13 of the Defamation Act; the government has explicitly omitted any consideration of

Ibid., para. 98.

Gay 2012, document No. SN/PC/06390, p. 18.

Ibid.

Green Paper on Parliamentary Privilege, Cm8318, published on 26 April 2012, paras. 100-101.

Ibid., paras. 183-192.

HC Bill 5 2012-2013, introduced on 10 May 2012.

HL Bill 41 2012-2013, transmitted from the Commons on 24 September 2012. 
parliamentary privilege, for which it deems a privilege bill which might potentially follow the consultation initiated by the Green Paper a more appropriate place. ${ }^{264}$ In May 2010, Lord Lester of Herne Hill had introduced a Defamation Bill to the House of Lords. ${ }^{265}$ It envisaged the repeal of section 13 of the Defamation Act 1996 and would instead have conferred the power to waive the privilege ex Article 9 of the Bill of Rights for an individual member to the Speaker of either House. ${ }^{266}$ However, Lord Lester's Bill was not continued after the second reading in the Lords. Considering that, according to the 2012 Green Paper, the government does not necessarily see the need for legislative action as regards defamation proceedings and parliamentary privilege, it is at this point open but not very likely that section 13 will be repealed or amended in the near future.

As a final point, the Green Paper contains a draft clause concerning the publication and broadcasting of proceedings in Parliament which would, in particular, amend the Parliamentary Papers Act 1840. ${ }^{267}$ This Act, adopted as a reaction to Stockdale $v$. Hansard, protects authorised publications of parliamentary proceedings from civil and criminal suits, such as for defamation. Section 3 of the Act extends this protection to publications which were not ordered by Parliament, but only in cases where the defendant can 'show that such extract or abstract was published bonâ fide and without malice'. The burden of proof thus lies with the defendant, which is rather unusual. Next to this, the opaque wording of some of its sections has also led to calls for modernisation - the 1999 Joint Committee referred to its 'somewhat impenetrable early Victorian style'. ${ }^{268}$ The draft clause contained in the Green Paper ${ }^{269}$ provides that malice has to be proven by the claimant. It also intends to afford equal protection to publications in any form, including audiovisual media and the internet. According to the Green Paper, the government does, however, not intend to create an absolute privilege for fair and accurate reporting, since this 'would remove the existing conditions in common and statute law that reports of parliamentary proceedings are in good faith and without malice'. ${ }^{270}$ As an example of why such an absolute privilege would not be desirable, the government refers to a scenario in which the media provides a member of Parliament with private information covered by a court injunction and encourages the member to use that information in parliamentary proceedings on which it can then report without having to fear legal consequences. 271 This would clearly constitute malicious use of proceedings, which the courts should be able to examine.

The consultation phase following the publication of the Green Paper ended in autumn 2012. Whether the draft clauses will be adopted and whether any other

Horne 2012, p. 6-7.

HL Bill 3 2010/11, introduced on 26 May 2010.

Ibid., S. 16.

1840 c. 9,3 and 4 Vict.

Joint Committee on Parliamentary Privilege, First Report, 1999, HL 43-I, HC 214-I, para. 342.

Green Paper on Parliamentary Privilege, Cm8318, published on 26 April 2012, paras. 75-76.

Ibid., para. 311.

Ibid. 
statutory legislation - perhaps even a full privilege code - will emerge from this government-led review remains to be seen in the near future.

\subsubsection{The Privilege of Freedom from Arrest}

It was noted earlier that the privilege of freedom from arrest never applied in criminal cases but was limited to arrest in civil cases. However, where a member of either House is arrested on a criminal charge, the relevant House must be informed immediately about the arrest and the nature of the charges. ${ }^{272}$ The same is true where a member of either House is given a prison sentence by a court. No such notification is necessary if a member's absence from the House is explained by his being elected to the House while detained. ${ }^{273}$

As has been mentioned earlier, since the Judgments Act 1838, arrest in civil cases is no longer practised except, as the case may be, in proceedings on bankruptcy according to the Insolvency Act 1986. ${ }^{274}$ For cases of bankruptcy of members of either House of Parliament, it is explicitly provided by statute that they be, upon declaration of their bankruptcy, disqualified from their seats in the Lords or Commons and that their seats be vacated. Further, persons thus disqualified may not return for membership of the Commons. ${ }^{275}$

One further non-criminal occasion for detention is detention under mental health legislation. Such detention seems possible for members of the Commons, since the relevant Mental Health Act 1983 contains a procedure for detention of members of that House. ${ }^{276}$ As to the Lords, their Committee on Privileges accepted that neither parliamentary privilege nor the privilege of peerage overrides mental health legislation and that detention is therefore possible. ${ }^{277}$

Apart from arrest, the privilege, until recently, extended to certain other events which may prevent a member from attending Parliament, especially being summoned before a court as a witness, or to serve on a Jury. It is clear that Parliament still has the supreme right to require the attendance of its members; yet, according to Erskine May, it is doubtful whether the privilege would today be strictly enforced. ${ }^{278}$ Where a member chooses to attend court, he is free to do so at

$272 \quad$ Leopold 1998, p. 82.

273 Ibid., p. 120 et seq. The election of a prisoner is certainly unlikely but not impossible, as illustrated by the case of John Daly. Mr Daly was elected to the Commons as a member for Limerick. However, he was disqualified by the house, since at the time of his election he was serving a life sentence for treason (for conspiring to blow up Westminster Parliament!). Daly was released one year later and became the mayor of Limerick.

274 Insolvency Act 1986 c. 45, as amended by the Insolvency Act 2000. Under s. 134 of this Act, a (former) office holder of an insolvent company may be arrested upon a court order if he fails to appear for his public examination.

$275 \quad$ Ibid., s. 426 A.

2761983 c. 20 , s. 141 . This section was not amended by the Mental Health Act 2007, leaving this procedure unchanged and omitting a clear reference to the Lords.

277 Erskine May 2004, p. 124

$278 \quad$ Ibid. 
any time, with or without formal leave. ${ }^{279}$ The exemption from jury service which members and officers of both Houses, and certain other peers, used to enjoy has been abrogated by the Criminal Justice Act 2003.

Whereas it appears that the privilege of freedom of arrest today is 'largely a historical artefact' 280 which has played its role especially in very early times of parliamentary history, it has never been completely abolished. It is clear that its relevance in modern times is more than marginal, and it is in no way comparable to the freedom of arrest as it follows from parliamentary inviolability in other jurisdictions, which usually prohibits the arrest of a member of Parliament, and other measures of investigation against him or her without prior authorisation by Parliament, save where he is apprehended flagrante delicto in committing a crime. The complete abolition of what remains of the British privilege of freedom of arrest has been recommended by parliamentary committees several times during the $20^{\text {th }}$ century, and was last done so by the Joint Committee in 1999 which viewed it as 'anomalous and of little value'. 281 Without explicitly saying so, the 2012 Green Paper on parliamentary privilege suggests the same, and therefore asks the question whether freedom from arrest in civil matters should be abolished. 282

That this privilege, which must indeed be deemed to add but very little to the necessary protection of Parliament, is outdated and can create unjustifiable adverse effects is illustrated by the case of Stourton $v$. Stourton. ${ }^{283}$ The wife of William M. Stourton, a Peer, had secured a decree of separation from her husband and was suing for the return of certain property. A court order was issued accordingly, but when Baron Stourton failed to comply (and thus was in contempt of court) the wife issued a summons for leave to issue a writ of attachment (arrest) against him. Baron Stourton countered this by pleading the parliamentary privilege of freedom from arrest, which he enjoyed as a Peer. After examining the nature of the writ of attachment, the court in that case concluded that it was not a means to punish the contemnor - which would have brought it into the sphere of criminal law to which the privilege does not apply - but a means of coercion in a civil matter. Therefore, Baron Stourton could indeed rely on privilege to avoid his arrest. As this case shows, a particular concern raised by the privilege of freedom from arrest is that there is no requirement of a functional connection of the matter in which the privilege is asserted with the parliamentary work of a member or Peer. While such a requirement has developed for the privileges of Article 9 of the Bill of Rights, with the effect that no privilege exists where parliamentary business is untouched by the case, freedom from arrest applied regardless of the circumstances of the case (although, or probably because, the cases in which it does apply are extremely rare). Due to the marginal role played by this privilege, the abolition of freedom from arrest appears to be a sensible choice. Yet, this could only be achieved by Parliament enacting a statute to that effect, which has so far not been done. Whether a potential

Ibid.

Chafetz 2007, p. 132.

(1998-99) H.L. 43, H.C. 214, para. 327.

Green Paper on Parliamentary Privilege, Cm8318, published on 26 April 2012, paras. 315-323.

Stourton v. Stourton (1963) 2 WLR 397. 
privilege bill, following consultations on the 2012 Green Paper, will address this issue is uncertain. Unless such a bill will actually endeavour a comprehensive codification of privilege, freedom from arrest in civil matters seems too unimportant an issue to be the subject of any forthcoming statute.

\subsubsection{The Enforcement of Privilege: Penal Powers of Parliament}

At the outset of this chapter we described how Parliament developed out of the ancient Curia Regis, a body that fulfilled a variety of tasks and did not distinguish between its legislative and judicial powers. These functions have subsequently grown apart and are now exercised by the King in Parliament and the courts respectively. However, with regard to lex parliamenti, Parliament is not only acting as a legislator; the two Houses both retain penal jurisdiction over so-called contempts. In this, the powers of the Houses of Parliament very much resemble those of judges where they exercise penal jurisdiction in cases of contempt of court. Erskine May explains that the origin of the power to punish for contempt is probably to be found in the medieval concept of the English Parliament as primarily a court of justice'. ${ }^{284}$ Indeed the power to penalise for contempt does resemble that same power as it accrues to the common law courts. It is noteworthy, in this respect, that the view of Parliament as a court, as least as regards its own affairs and the lex parliamenti, is still alive today, as for example in the Nolan Report of 1995, where it is argued that 'it is [...] important for Parliament, the highest Court in the land, to have established procedures which operate as a matter of course rather than of chance' 285

The term contempt does not come with a precise definition. It is clear, however, that contempt must be understood as a concept much wider than only the breach of one of the privileges enjoyed by Parliament:

[A]ny act or omission which obstructs or impedes either House of Parliament in the performance of its functions, or which obstructs or impedes a member or officer of such House in the discharge of his duty, or which has a tendency, directly or indirectly, to produce such results, may be treated as a contempt, even if there is no precedence of the offence. ${ }^{286}$

In addition to this extremely broad definition of contempt, the exercise by either House of Parliament of its penal powers is discretionary: no body or individual but the relevant House itself is competent to decide whether a contempt has occurred and whether and how it should be punished. However, upon recommendation of the Committee of Privileges ${ }^{287}$ the House of Commons resolved in 1978 to exercise

$284 \quad$ Erskine May 2004, p. 167.

285 Public Life, First Report of the Committee of Standards in Public Life [Nolan Report], 1995, para. 90.

286 Erskine May 2004, p. 128

287 Third Report of the Committee of Privileges 1976-1977, HC 417, paras. 9-12. 
its penal jurisdiction 'in any event as sparingly as possible, and only when satisfied that to do so is essential to provide reasonable protection for the House' ${ }^{288}$

It must be noted that under the law of contempt on which the penal powers of Parliament are based there is no need for a breach of any clearly defined privilege or any other precisely formulated legal rule. The above definition by Erskine May makes this abundantly clear. Since the law of contempt does not in fact require any previously defined conditions to be met in order for one of the Houses to make use of its penal powers, it is in principle evident that the law of contempt does not abide by the principle of 'nullum crimen, nulla poena sine praevia lege poenali'. In practice, however, this no longer seems to bear as much adverse effect as might be expected, as at least the House of Commons has self-limited the use of its penal powers. This does not, of course, limit the competence of any (consecutive) Parliament to make use of such powers in the manner it pleases, since ' $t$ t]he Houses, and they alone, are the proper judges of when these powers may be rightly exercised' ${ }^{289}$

What exactly are the penal powers of Parliament? First of all, both Houses have the power to order persons to appear before them to answer charges of contempt or breach of privilege. ${ }^{290}$ This is true for both members and non-members of the respective House; notification of the object or cause of the order is not required.291 As to further-reaching punishments, it seems that one had, until very recently, to make a distinction between the House of Lords, which was undoubtedly a court of record and thereby was able to inflict all forms of punishments which other courts of record have at their disposal, and the House of Commons, whose status as a court of record has historically been asserted but is nonetheless doubtful. ${ }^{292}$ In consequence, the possibility to punish by imposing a fine was only open to the House of Lords. It is likely that this possibility no longer exists since the House of Lords ceased to be a court of record. Both Houses, however, have the power to commit, id est, imprison, those they find guilty of a grave contempt or breach of privilege. Whereas the Lords commit by simple order, the Commons usually issue a warrant to that effect. While power of the Lords, as the highest 'regular' court, to impose proper prison sentences has not been doubted, it has historically been uncertain whether the Commons enjoy this power without any restriction or whether the ordinary courts (and thereby previously the House of Lords) are competent to review the cause for committal and possibly admit a committed person to bail. According to Erskine May, a distinction has subsequently been made between situations where a warrant for committal, issued by the

Erskine May 2004, p. 167

Ibid., p. 156. See in this respect Gosset v. Howard (1847) 116 ER 158.

Erskine May 2004, p. 156

Ibid.

Ibid., p. 161. Since the UK Supreme Court started to operate in October 2009 and replaced the House of Lords as the highest regular court of the United Kingdom, it is likely that the status of the House of Lords must today be equated to that of the House of Commons. As constituent parts of the High Court of Parliament, however both exercising their penal jurisdiction independently, they can be seen as courts equipped with jurisdiction over lex parliamenti. 
Commons, is expressed 'in general terms'293 or whether it states explicit facts constituting the contempt for which the person in question is committed. Curiously, in the former case it has historically been held that:

When the House of Commons adjudge anything to be a contempt or a breach of privilege, their adjudication is a conviction, and their commitment in the consequence is execution; and no court can discharge or bail a person that is in execution by the judgment of any other court. ${ }^{294}$

This was tantamount to acknowledging that (a) the Commons, at least with respect to their own privileges and with respect to contempt of their House, are a court of law and (b) that consequently the other courts had no right to review decisions of the Commons as to the content and scope of their privileges and of what does or does not constitute contempt. In cases where the warrant does state facts and reasons for committal, it has been observed that courts 'may be obliged to consider it and pronounce it defective' ${ }^{295}$ It is uncertain whether courts would or would not take this view today.

It has been acknowledged that the Lords, when they were still a court of record, had the powers to commit for a specified term, id est, to impose a fixed prison sentence. According to Erskine May, the House of Commons 'is now considered as without power to imprison beyond the session' 296 so that prisoners must be released upon the prorogation of Parliament. At the time the Commons last used their powers to commit persons for contempt, it was practice 'to keep them in custody until they presented petitions expressing proper contrition for their offences and praying for their release $[\ldots]^{\prime}{ }^{297}$ A similar practice has been used in the Lords.

With respect to members of the Commons, the House can also inflict the punishments of reprimand, suspension, or expulsion from the House, the latter two accompanied by withholding the salary of the respective member. The Lords do not have the power to exclude a member of their House permanently. ${ }^{298}$

Lastly, where the offence in question is not merely a contempt or a breach of privilege, but in addition also an offence under the normal law of the land, such as assault (or in fact any offence), both Houses have the power - and have made use of it - to direct the Attorney General to commence prosecution. While this is quite logical and does, in principle, not give rise to much difficulty, it must be noted that this does not take away the power of the respective House to exercise its penal jurisdiction. Thus, a person could theoretically be prosecuted for an offence at law and for contempt at the same time, contingently receiving a prison sentence by a court and being committed by the relevant House. The likelihood for this scenario

Ibid., p. 158.

Brass Crosby's case (1771) 95 ER 1011.

Burdett v. Abbot (1810) 104 ER 501.

Erskine May 2004, p. 160-161.

Erskine May 2004, p. 161 Erskine May lists a number of examples from the 19th century (note 1). Detainees were also frequently reprimanded before they were freed upon their petition. Erskine May 2004, p. 163. 
to become reality is undoubtedly low; however as an academic thought experiment it does reveal, once more, the peculiar nature of the relationship between the lex parliamenti and the law of the land.

Another scenario which has proven problematic in the past is the fact that, while certain matters fall under the exclusive jurisdiction of Parliament and are therefore only justiciable in the relevant House, acting as a court, there is no 'regular' way of legal recourse to that House. This means that non-members who lack a remedy in the ordinary courts for matters which fall under privilege have no legal means of instigating proceedings. A complaint of breach of privilege or contempt may only be made by a Member of Parliament, by written notice to the Speaker of the House who will, under his discretion regarding the priority to be granted to the matter, proceed to bring it to the attention of the House. ${ }^{299}$ This lack of a commonly available remedy has given rise to human rights concerns in the context of British parliamentary privilege.

Of course, neither Chamber is likely to make use of the more extreme punishments which it theoretically has at its disposal to avenge contempt. It is quite safe to predict that we will not see anyone thrown into a parliamentary dungeon again. One reason for this is certainly that this would simply not fit a modern conception of the rule of law and that it would cause public outrage. However, a much more important reason for the demise of Parliament's penal powers - or rather of their being used - lies in the increasing curtailment of parliamentary privilege itself. After all, Parliament can only punish for contempt.

We have already observed that contempt does not necessarily have to correspond with a breach of privilege. However, where privilege is not at issue and an offence is sufficiently grave, it falls within the realm of the law of the land. This means that the ordinary courts have jurisdiction and Parliament is probably not inclined to exercise concurrent jurisdiction. In other words, the penal powers of Parliament were much more useful, and in fact very much needed, when Parliament still had truly exclusive jurisdiction over near enough everything that happened within its precincts. Certainly, grave criminal offences (like the murder of the Prime Minister in the Lobby of the House of Commons) were at all times subject to the jurisdiction of the ordinary courts. Nevertheless, until well into the $20^{\text {th }}$ century (Graham Campbell was decided in 1935!) the judges still largely adhered to the doctrine that 'a Court knows nothing judicially of what takes place in Parliament' ${ }^{\prime 300}$ and kept well clear of matters which fell within their relatively wide interpretation of exclusive cognisance. Today, Parliament may reprimand or require apologies of members or other persons who use inappropriate language in proceedings. It may even punish a member for damaging the mace. But already - to use the most recent example again - defrauding the House of Commons' allowances scheme is no longer considered a matter for the penal powers of the House.

$299 \quad$ Erskine May 2004, p. 167.

$300 \quad$ Wellesley v. Beaufort (1827) 2 Russell 1; 28 ER 236. 


\section{Conclusion}

This chapter has been a long journey through the legal field of British parliamentary privilege and the law of Parliament. We are now able to draw a set of conclusions about privilege. Before doing so, however, we must consider one important caveat: for reasons closely entangled with British parliamentary history and with the nature of its common law legal system, a succinct and final definition of the nature of parliamentary privilege, its scope, and its content cannot be distilled from any examination, however comprehensive or specific. The reason for this is that the law has never produced such a definition - that it has rejected the idea of a clear-cut concept. On the one hand, the need for absolute certainty has never arisen with sufficient urgency, partly because the vagueness of the law was widely held to be beneficial and can also be expressed in the more positive term 'flexibility'. On the other hand, none of the relevant actors (the two Houses of Parliament, the courts, and the Crown) has ever had sufficient authority to impose such a definition on the respective others and thereby risk latent conflict to flare up. This notion, it must be said, is a very ironic one. There was never an incisive moment in the history of Parliament and its privileges at which the separation of powers between Parliament and the courts had fully and formally been established, and the remainder of the historic mingling of functions between the two remains today as a historic artefact, but one which is still relevant where the application of privilege is concerned. The irony lies in the fact that, very probably, it was exactly the non-occurrence of a sudden formal-constitutional separation of powers which has eventually proven to preserve the inter-institutional checks and balances which other systems had to create artificially, such as by inscribing them in a definite and rigid constitution.

In the light of these considerations, what are the 'peculiar rights' which, according to Erskine May, constitute privilege in their sum? We can infer from the discussion of privilege in this chapter that all privileges derive ultimately from one principle, namely that Parliament rules autonomously over its own affairs and that it does so in order to secure the unimpeded and effective discharge of its constitutional tasks (id est, primarily its tasks as a legislator). This is the principle of exclusive cognisance. Within this über-privilege, eclipsing all other specific privileges, the most important privilege is that of Article 9 of the Bill of Rights 1689: proceedings in Parliament must not be impeached or questioned by any person or institution out of Parliament. As a basic principle, this privilege still stands firmly. However its scope has been increasingly curtailed by statute, case law and Parliament's own interpretation. Even though the precise boundaries remain somewhat unclear, certain conclusions are safe: proceedings in Parliament include first and foremost everything said within parliamentary debates and any written documents which contribute to such debates. At times, proceedings may reach slightly beyond this. As a blunt rule of thumb, the more connected a potential proceeding is with matters belonging to the core tasks of Parliament, the more likely they are to be covered by Article 9 of the Bill of Rights. Meanwhile, it is clear that Parliament as a geographical lieu of application of privilege is no longer of supreme importance, albeit that speech and debate that does not take place at the Palace of Westminster does not usually qualify for privilege. 
What exactly may not be done with regard to speech, debate, and proceedings in Parliament? So far, they certainly may not be impeached or questioned. That is, they may not be attacked, examined as to their truth, misrepresented to the public or otherwise, or treated in any other way which might harm their integrity as elements of parliamentary proceedings. In the future, if legislation to that effect is adopted, this might change in that proceedings will be allowed as evidence in criminal cases, which would necessarily involve their 'questioning'. Today, proceedings may already be used by courts in order to identify the intended aim and content of statute or government policy. The courts may also use proceedings where they merely serve to establish facts, id est, where they are not in any way impeached but merely 'registered'. Proceedings may be reported to the public, but only where such is done accurately and without malice, and if Parliament has not prohibited their publication. However, it must be noted that publications and restatements of parliamentary proceedings outside Parliament are not in themselves parliamentary proceedings and are therefore not automatically privileged as such. This means, for instance, that privilege will not bar legal action for defamation against a publisher or broadcaster if the latter has published a parliamentary statement with malicious intent, even if the statement was accurately reproduced.

Next to the privilege of freedom of speech, there still exists, nominally, the privilege of freedom from civil arrest. However, as civil arrest has ceased to be a common occurrence in British law, this privilege has long since been marginalised. The privilege might be relevant in the unlikely case of imprisonment for contempt of court. Moreover, civil arrest is still possible in certain cases under bankruptcy law; however, bankruptcy of a member of the Commons also leads to the loss of the mandate, thus making the application of the privilege superfluous. With regard to Peers, however, the privilege of freedom from arrest could possibly still be applied.

Other statutes either explicitly provide for their applicability to parliamentarians regardless of the privilege, or the Houses have resolved not to apply the privilege in the cases pertaining to these statutes (the latter is the case under mental health legislation). Overall, the privilege of freedom from arrest has all but lost its practical relevance.

For the enforcement of its privilege, Parliament is still equipped with penal powers. Those powers are also inherent in the notion that Parliament must be able to take charge of its own affairs, and do so exclusively. Even though there is no doubt as to their existence, the penal powers of Parliament are very rarely applied in modern times, primarily due to the curtailment of exclusive cognisance: there is little left over which the two Houses have exclusive jurisdiction, as statute, case law and the voluntary deference of Parliament have created extensive inroads through which the courts have gained access to matters which once fell under exclusive cognisance.

The latter is of importance for the question of how the law of Parliament relates to the law of the land. We have illustrated that this question of constitutional theory cannot be finally resolved: there are two theories, one of which states that lex terrae and lex parliamenti are in fact two different and separate legal systems which co-exist, but where it is for the administrators of lex terrae (that is, the courts) to 
determine the borderline between the two. The other theory treats lex parliamenti as a part of lex terrae in which, however, the material and procedural rules of the latter are of limited application. Both are supported by a long range of historic precedence and by a body of constitutional doctrine; however it is for the want of an imposed, conclusive definition that none of the two can ultimately be proven right or wrong. In practice, however, this is of little relevance. While friction may arise from time to time between Parliament and the courts, history (continuing up until very recent case law) has shown that it is in fact a constitutional convention for both institutions, Parliament and the courts, to avoid conflict in this matter. Case law shows, however, that privilege has recently been treated as merely an exception to the otherwise applicable law. In practice, privilege takes the form of a procedural bar for court proceedings rather than being treated as its very own body of rules.

Much of what we have seen in our examination of the modern privileges indicates one very clear general trend: both the courts and Parliament increasingly interpret, assess and apply privilege according to a functional approach. This means that privilege is still deemed important in order to protect and guarantee the unimpeded performance of the core functions of Parliament - but no more than that. Hence, we can observe that recent developments of British parliamentary privilege constitute case in point for our hypothesis that immunity systems are generally evolving towards a functional approach.

A century ago, it would have been almost unthinkable not to treat the expenses claims submitted by members of the Commons as proceedings in Parliament; ${ }^{301}$ the search of an MP's parliamentary office without a warrant would have been treated as contempt of Parliament. Until Pepper v. Hart, so as recently as 1993, the prohibition to 'impeach or question' proceedings in court was taken to mean that judges could not even refer to proceedings in order to elicit the true intention behind the wording of an Act of Parliament. Twenty years later, the government has proposed legislation which would explicitly allow the use of proceedings as evidence in nearly all criminal cases (with the exception of offences relating directly to freedom of speech in Parliament); and such use would certainly include the 'questioning' of proceedings. Already from 1996 section 13 of the Defamation Act has allowed individual members to waive privilege in certain cases. The Supreme Court's decision in $R v$. Chaytor has shown that the privilege of exclusive cognisance does not fill the gap which the ever narrower privilege of Article 9 leaves on its retreat. Seen individually, these developments are incidental. Neither the courts, Parliament, or its committees (or the government, in its Green Paper) have formally and explicitly committed to an agenda which aims at reducing the overall scope of privilege. Nevertheless, they have done just that. What has changed is the general attitude towards the purpose of privilege: it is now understood to serve a specific function, to protect Parliament from undue influence and enable it to carry out its constitutional tasks. At the outset of this chapter we stated that parliamentary privilege is more than just the British term for parliamentary immunity. However,

301 If any allowances for members had existed. Prior to 1911, members of Parliament did not receive any salary and could not claim expenses. 
the functional reduction of parliamentary privilege, the demise of the notion of lex parliamenti as a special legal territory, leads to the daring conclusion that privilege is developing to become just that: parliamentary immunity, much as it exists elsewhere. 
Chapter 4

\section{PARLIAMENTARY IMMUNITY IN FRANCE}

\section{Introduction}

\subsection{Structure of this Case Study}

Following this introduction (part one) are four component parts to this case study. In part two, the history of parliamentary immunity is explored with a particular focus on the French Revolution, in which both French parliamentarianism in general and parliamentary immunity in particular find their common origin. In this part particular regard will be given to the interrelation between the revolutionary events and the shaping of the first immunity provisions.

Part three is devoted to an account and analysis of the theoretical foundations and justifications of parliamentary immunity and its two elements, irresponsabilité (non-accountability) and inviolabilité (inviolability), respectively. Part four describes and analyses the current law and practice of parliamentary immunity and discusses legal problems existing in their context. Finally, part five lays out the conclusions which can be drawn from this analysis of the French system of parliamentary immunity.

\subsection{Parliamentary Immunity in France}

This case study examines the system of parliamentary immunity of the French legislature, consisting of the National Assembly and the Senate. The French immunity regime is laid down in Article 26 of the French Constitution, which reads as follows:

No member of parliament may be prosecuted, investigated, arrested, detained or tried based on opinions expressed or votes cast by him in the exercise of his functions.

No member of parliament may be arrested or subjected to any other measure of a criminal or correctional nature depriving him of or restricting his liberty without the authorisation of the bureau of the Chamber to which he belongs. Such authorisation is not required in case of a crime or misdemeanour in flagrante delicto or in case of a final conviction. 
The detention of a member of parliament, any measures depriving him of or restricting his liberty, or his prosecution shall be suspended for the period of the session if the Chamber to which he belongs so requires.

The affected Chamber shall convene by operation of the law for supplementary meetings in order to allow, where appropriate, the application of the preceding paragraph. ${ }^{1}$

Article 26 thus creates a two-tier immunity in which two distinct elements together provide parliamentarians with a relatively wide protective shield. On the one hand, non-accountability (irresponsabilité) ex paragraph 1 protects members of either chamber of parliament from legal action or any measure of investigation or prosecution for opinions expressed and votes cast in the exercise of their mandate. On the other hand, inviolability (inviolabilite) ex paragraph two protects members of either chamber from being deprived of their liberty (that is, from being arrested or detained) in criminal or correctional matters, save flagrante delicto, without the approval of the bureau of their respective chamber. This second layer of immunity extends to matters which are not covered by inviolability: anything that goes beyond 'opinions or votes expressed in the exercise of the parliamentary mandate'. Whereas non-accountability is absolute and perpetual, inviolability is limited ratione temporis to the parliamentary session, does not apply in the case of an arrest flagrante delicto or a final criminal sentence and may be lifted by the bureau ${ }^{2}$ of the respective

1 The French original reads as follows:

'Aucun membre du Parlement ne peut être poursuivi, recherché, arrêté, détenu ou jugé à l'occasion des opinions ou votes émis par lui dans l'exercice de ses fonctions.

Aucun membre du Parlement ne peut faire l'objet, en matière criminelle ou correctionnelle, d'une arrestation ou de toute autre mesure privative ou restrictive de liberté qu'avec l'autorisation du Bureau de l'assemblée dont il fait partie. Cette autorisation n'est pas requise en cas de crime ou délit flagrant ou de condamnation définitive.

La détention, les mesures privatives ou restrictives de liberté ou la poursuite d'un membre du Parlement sont suspendues pour la durée de la session si l'assemblée dont il fait partie le requiert.

L'assemblée intéressée est réunie de plein droit pour des séances supplémentaires pour permettre, le cas échéant, l'application de l'alinéa ci-dessus'.

2 The bureau is the executive organ of either chamber. It regulates its deliberations and organises its services (see Art. 14 of the règlement of the National Assembly, Art. 2 of the règlement of the Senate). In the National Assembly, it comprises the president of the Assembly, six vice-presidents, three questeurs (treasurers) and twelve secretaries (Art. 8 of the règlement of the National Assembly). Except for the president, who is elected for the entire legislature, the members of the bureau are elected annually, except in the year preceding general elections. A list of candidates is drawn up by the leaders of the political groups. If the list of candidates for one of the bureau functions does not exceed the number of offices available, the candidates are appointed. Otherwise, they are elected, using a majoritarian list system (scrutin plurinominal majoritaire) (Art. 10). This way, the political configuration of the bureau roughly matches that of the Assembly, which the reglement explicitly recognises as the purpose of these elections (Art. 10(2)). The bureau of the Senate comprises the president of the Senate, eight vice-presidents, three treasurers and 14 secretaries. The Senate also has a procedure in place to ensure the proportional representation of the political groups in the bureau (see Art. 3 of the règlement of the Senate). That the political configuration of the 
chamber. However, pursuant to sub-paragraph three of Article 26, either chamber of parliament has the power to demand the suspension, for the duration of the chamber's session, of any measure of prosecution or detention of one of its members.

Like all other countries with a system of parliamentary immunity, France is confronted with the fundamental dilemma which lies in the fact that immunity stands in contrast - or possibly even conflicts - with the principle of equality before the law enshrined in democratic constitutions. ${ }^{3}$ Nevertheless, some degree of parliamentary immunity is regarded as a fundamental and necessary safeguard of the functioning of parliament in that democratic system. ${ }^{4}$ It has therefore been described as an 'inégalité qui est un fondement de la démocratie parlementaire'. ${ }^{5}$

However, even if one accepts that parliamentary immunity is thus justified in principle, its scope and legal implementation as well as its application in practice always requires careful balancing - and occasional re-balancing, as the sociopolitical and institutional framework in which parliaments operate are subject to evolutionary processes and change. This case study endeavours to elicit the French solution to the immunity dilemma, to examine the particular balance which the French immunity system has found (and occasionally lost during parts of its history) between the competing legal needs of protecting the legislature and safeguarding equality before the law.

\subsection{Delineation}

In its examination of parliamentary immunity in France, this chapter is limited to the national parliament of the French Republic. Assemblies which exist at a subnational level (namely the regional, departmental and communal councils) as well as the parliaments of other entities or states, in particular former French colonies, whose parliamentary systems are sometimes modelled after the French example, are not considered. This twofold delineation is necessary for the following reasons.

First, France is a unitary state in which the constitutional nature of the subnational territorial entities is in essence that of an administrative organ rather than a sub-state. Accordingly, regional assemblies cannot be equated to parliaments as they exist on a sub-national level in federal states or in the countries of the United Kingdom by virtue of devolution legislation (where they do possess legislative capacity, if only at the will of the central legislator). The assemblies of the French sub-national assemblies (conseils municipaux, généraux, régionaux) do not possess

respective bureaux reflects that of the chambers should be borne in mind when considering the role of the bureaux in lifting parliamentary inviolability.

3 This is also true for the French constitution. Art. 1 assigns the republic with the task to ensure the equality of all citizens before the law. The first article of the Declaration of the Rights of Man and the Citizen of 26 August 1789 states that '[m]en are born and remain free and equal in rights'.

4 While this thought is occasionally questioned in the literature (in particular as regards inviolability), it is still the prevalent legal opinion. See amongst others: Bigaut 1996, p. 81 et seq. Luchaire \& Conac 1980, p. 440. 
proper legislative powers. While they do have the (limited) competence to issue regulations (règlement) and to take policy decisions in local matters, ${ }^{6}$ these powers depend entirely on the competences attributed to the communes, départements and régions by statute. Thus, although deliberations of a political nature do take place in the assemblies of the respective territorial entities, the latter should be considered as administrative rather than legislative bodies. Since the object of the present study is a comparison of the immunity systems of national legislative bodies, a detailed examination of the immunities of members of the French sub-national assemblies would exceed our purpose, as it would not contribute to the envisaged comparison. However, it can be noted at this point that the members of sub-national assemblies in France are not fully devoid of protection: they enjoy a limited form of professional immunity for unintentional misdemeanours in office. ${ }^{7}$

Second, although the parliamentary systems of many countries predominantly former French colonies in Francophone Africa, have been modelled after the French example, their immunity systems are also not considered in this chapter. While some of them certainly offer interesting aspects for a study of parliamentary immunity, it is nonetheless justifiable not to take them into account here. Not only would a detailed examination of these systems exceed the scope of this study, they would also, for the most part, lack the necessary comparability on a variety of important social, political and economic issues with the three European systems studied. Moreover, there is no continued legal interdependence, similar to that between the British law of parliamentary privilege and that of other Commonwealth countries, ${ }^{8}$ between the French system and those derived from it, which would merit and, in fact, necessitate such an examination.

\section{The History of Parliamentary Immunity in France}

This part of the present chapter is devoted to the history of the French parliamentary immunity regime, concerning the immunities enjoyed by members of the consecutive legislative bodies which existed after the Revolution, up until the

$6 \quad$ Under Art. 72 of the constitution, the territorial entities administer themselves freely through elected councils and possess regulatory powers [pouvoirs réglementaires] for the exercise of their competences, which are attributed to them by law. The competences of the three levels of local government, the communes, départements and régions lie in the field of cultural, social, environmental and economic affairs, as well as education.

$7 \quad$ Members of municipal, departmental and regional councils as well as the respective mayors and presidents of these councils may not, on the basis of Arts. 121-123 of the Criminal Code, be convicted for unintentional acts committed in the exercise of their functions, even where these would otherwise be punishable as misdemeanours, safe where it is established that they did not act with reasonable diligence and effort (Arts. L2123-34, L3123-28 and L4135-28 of the General Territorial Collectives Act [Code général des collectivités territoriales]. There is no such protection in case of punishable acts committed intentionally, nor for punishable acts committed in the extra-professional sphere. Interestingly, there is also no form of nonaccountability, e.g. for utterances in council, even though the proceedings in these subnational organs must be considered political - i.e. deliberative, but not legislative in nature. E.g. through Privy Council case law with precedent value for the UK; see Chapter III. 
establishment of the Fifth Republic in 1958. While all relevant constitutional provisions will be dealt with in the chronological order of each constitution, the primary focus of this historical account will rest on the earliest occurrence of parliamentary immunity in the days of the Revolution. As will be shown, this focus is justified by the importance which must be ascribed, in hindsight, to the revolutionary events which first gave rise to the idea of parliamentary immunity in France and which must still be seen as the foundation on which all later immunity systems were built.

\subsection{The Concept of Parliament in Pre-revolutionary France}

Very much unlike its counterpart in Westminster, the French parliament - or the concept of parliament in France ${ }^{9}$ - cannot trace its origins back to the uncertain depths of early medieval history. Instead, its existence, along with that of the entirety of France's modern constitutional tradition, is largely owed to one incisive moment in history: the French Revolution. The revolutionary National Assembly is therefore the natural starting point for an analysis of the history of parliamentary immunity in France.

This does not mean, however, that no representative and consultative bodies existed in pre-revolutionary France. Numerous national and regional assemblies were convened from time to time; however, none of them reached the level of institutionalisation which is commonly associated with a parliament, and which already existed in Westminster during the Middle Ages. While not all of the prerevolutionary assemblies are of interest in the context of this study, some of them will be briefly discussed, in order to provide an understanding and conceptual delineation of the notion of parliament prior to the Revolution.

\subsubsection{Representative and consultative assemblies in pre-revolutionary France}

\subsubsection{The Curia Regis}

In Capetian France, ${ }^{10}$ a medieval kingdom with feudal structures comparable to those which existed across Europe at the time, there was a Curia Regis, a council of the King's highest-ranking vassals similar to the one found in Anglo-Norman England, which is assumed to have exercised mainly judicial functions, ${ }^{11}$ but which also more generally served as a forum for the feudal interrelations and interactions between the monarch and his tenants-in-chief. Along with this assembly of the highest-ranking vassals there were a number of other consultative assemblies. These

9 On the term 'parliament' in the context of the Ancien Régime and the question whether the pre-revolutionary États Généraux can rightfully be called a parliament in the modern sense, see below

10 After the dynastic House of Capet, which ruled France from 987 until 1328.

11 Major 1980, p. 10 
were convened irregularly and without a fixed composition at the behest of the King to advise him upon request, but had no binding power. ${ }^{12}$

\subsubsection{The Conseil du Roi}

Over time, the old curia regis has split up into separate and more permanent organs, such as the chambre des comptes, ${ }^{13}$ parlement and a conseil d'état ${ }^{14}$ which together formed the conseil $d u$ roi (the latter is to be understood as an umbrella term for all the institutions auxiliary to the King). Duverger notes that these institutions were composed of members of the nobility and clergy as well as relatives of the King, who had a traditional claim to membership of the conseil, but also with 'functionaries of modest origin but of great competence'.${ }^{15}$ Over time, the monarchy, developing towards absolutism, increasingly sought to put the latter category of non-noble members of the different sub-organs of the conseil in a dominant position by either eliminating the old feudal Lords from the conseil, or by confining them to purely honorary positions. ${ }^{16}$

\subsubsection{Parlement}

One of the organs which formed part of the conseil du roi was the parlement. Despite the similarity in names, the institution of parlement under the French monarchy must be clearly distinguished from Parliament as it existed in England at the time, or from our modern conception of parliament as a body with legislative and representative functions. From medieval times up until the $18^{\text {th }}$ century, the term parlement was used to refer to a variety of regional or provincial councils which primarily functioned as courts or tribunals, exercising regional jurisdiction (in the absence of a central, codified body of law). ${ }^{17}$

Ibid.

A court of audit which originated in a specialised section of the curia regis and later became an independent proto-institution.

14 The name conseil d'État first appeared in 1578 under King Henri III; it referred to the section of the royal council which was charged with the interior administration of the kingdom and with jurisdiction in administrative disputes. Later, a special judicial section, referred to as the conseil d'État privé or conseil privé assumed the role of a court of last instance. In absolutism the monarch retained the right to dispense justice and interpret the law with final authority (justice retenue), so the conseil d'État privé exercised supreme jurisdiction and had the power to overturn judgments of the parlements (see below), primarily on grounds of errors of law or interpretation. The conseil d'État privé can thus technically be said to be ancestral to today's Court of Cassation. (while in an absolute monarchy this will probably have meant to overturn judgments which displeased the monarch). For an informative historical overview, see the website of the modern Conseil d'État, the highest administrative court in France.

15 Duverger 1991, p. 19.

Ibid.

Whereas initially there was only one parlement (of Paris), similar organs were established as new territories and were incorporated in the kingdom. These factually separate assemblies existed under the fiction of forming an aggregate institution of parlement, hence the singular use of the word. 
This does not mean that the parlement did not play any political role. It must be borne in mind that the concept of separation of powers was entirely absent from pre-revolutionary political reality in France, to the effect that the entities collectively referred to as parlement, in their decisions as well as in their self-perception, could also be seen as political bodies. ${ }^{18}$ Regional parlements, however, had the important task of receiving and implementing royal edicts and decrees, which did not take effect until their registration with the parlement and other high courts. They also had the right to raise objections or make remonstrance against royal orders or legislation, which could then only take effect after having been registered with the parlement in the King's personal presence, in a procedure referred to as 'lit de justice'. Duverger observes that, in this respect, the parlement played a role of 'conseil $a$ posteriori', as it gave its advice only after an initial royal decision had been taken. ${ }^{19}$ Despite the self-image of the regional parlements, however, who collectively regarded themselves as 'le gardien des lois fondamentales du royaume', ${ }^{20}$ the final decision was always the King's alone. Nevertheless, their resistance could at times be considerable. The reason for this is found in the relative independence vis-à-vis the monarch, which the parlements enjoyed mainly because membership was either venal or hereditary, and so not subject to royal nomination. This also makes it evident, however, that the institution of the parlement did not bear any element of representation of the people or nation, other than perhaps in their self-perception: 'Le Parlement n'était representatif que dans l'imagination des parlementaires' ${ }^{21}$

\subsubsection{Les États Généraux}

Of all the pre-revolutionary institutions in France, the one which certainly bore the closest resemblance to a parliament in the modern sense, and which was eventually transformed into one in the Revolution, was the états généraux. However, prior to the Revolution the états also still lacked many characteristics of a modern parliament - for example, they did not have regular sessions or an institutionalised set of functions and powers.22 Originally conceived as one of the various bodies which together formed the conseil $d u$ roi, it did not develop a fixed form and

Duverger 1991, p. 25.

Ibid.

Duverger 1991, p. 26 et seq. Duverger also discusses the content of these fundamental laws and in how far the (increasingly absolute) monarch was bound by them.

Duverger 1991, p. 27

22 In principle, the King was at complete liberty to ignore the advice of the états généraux. Notable exceptions were the right of the états to determine royal succession in the case of a vacancy of the throne (i.e. in case there was no heir) and the right to authorise new taxes - or to refuse their imposition. While the latter can be seen as an important right with the potential to strengthen the institution exercising it (as was the case in the UK after Magna Carta), several factors prevented such a development in France. On the one hand, taxes, once granted, could be levied by the Crown without any temporal constraints, since only new taxes required authorisation. On the other hand, the lack of regular meeting intervals of the états and the habit of Kings to levy new taxes even without the authorisation of the états prevented its emergence as a powerful organ of state. 
organisation until the late $15^{\text {th }}$ century, by which time it had already degenerated into 'an occasional instrument to be used in time of crisis'. ${ }^{23}$ Such crises frequently took the form of wars which required funding. The King therefore had to raise taxes for which he requested the consent and collaboration of his vassals in the états généraux, often without success, which led to the rare use of the assembly and the (formally illegal) imposition of taxes without its consent. Maingot notes, therefore, that '[i]n France by the end of the $15^{\text {th }}$ century, the Estates General could be said to have acquired its main characteristics but it was not nor would ever become an institution' ${ }^{24}$

In 1614 the états généraux was convened for the last time in the prerevolutionary era, formally on the occasion of Louis XIII reaching majority age, but more likely upon the pressure of the nobility who sought to preserve their influence against emerging absolutism.

\subsubsection{The États Généraux as a Proto-parliament}

Despite its irregular sessions, its institutional weakness and the lack of clear-cut functions and powers which was typical for the institutions of medieval states, the aspect which nonetheless could justify a view of the états généraux as a protoparliament is its representative nature. Having been first convened in 1302 by King Philippe IV, ${ }^{25}$ its members were elected by the members of the three estates, the nobility, clergy and the tiers état (the third estate, primarily peasants and craftsmen).

The election system for the états has changed often over time, but the états généraux of 1789 was, among other things, particularly noteworthy for its remarkably democratic election mode: while elections were held by estate (clergy, nobility and the third estate voted separately for their respective representatives), every born or naturalised Frenchman of at least 25 years of age who was inscribed in the tax register and had his domicile in one of the electoral districts had the right to vote. ${ }^{26}$ Apart from a citizen's status as a tax payer, which required at least a minimum level of wealth, there was thus no census or other requirement apart from nationality, age and domicile. This made suffrage for the elections of the états généraux of 1789 considerably more 'universal' than it was under many postrevolutionary constitutional systems to come. ${ }^{27}$ In the unusual case that a woman held a fief of her own she was also entitled to vote, to the effect that even female suffrage was not completely excluded. ${ }^{28}$

23 Major 1980, p. 11. Major notes that the assemblies of Paris (1302) or Tours (1308) have often been named as the origin of the National Assembly in its final form. He argues, however, that this is wrong, since other national assemblies have been convened during the same period, but with a different composition and for different purposes.

$24 \quad$ Maingot 2010, p. 39.

Also referred to as Philippe the Fair, 1268-1314.

See the règlement électoral, reproduced in Brette 1894-1915.

See on this point Thumerel 2010

Art. XX of the règlement électoral, see also Duverger 1991, p. 22. Note, however, that this is a truly marginal exception. Due to the requirement of holding an independent fief, only very 
Once elected, the états généraux only theoretically formed one assembly; in reality, the representatives of the three estates met and voted separately (vote par ordre). Whereas in previous états all three estates were represented by an equal number of deputies, the representation of the tiers had been doubled in that of 1789 . However, this did not greatly improve the representativeness of the états généraux, nor did it initially lead to a shift of power towards the tiers: on the one hand, the third estate, whose members made up about 96 per cent of the French population, was still significantly underrepresented. On the other hand, more importantly, the vote by estate was initially maintained, so that the increase in the number of deputies for the tiers did not add to its political weight. The ensuing country-wide campaign for substituting the vote by estate by an individual vote par tête provoked the transformation of the états généraux into the Assemblée Nationale and thereby initiated the Revolution on the parliamentary level. ${ }^{29}$

An important characteristic of the pre-revolutionary états which clearly distinguishes it from later French parliaments is the nature of the mandate of its members. ${ }^{30}$ Representation in the états généraux was direct in the sense that the deputies received from their constituents an 'imperative mandate'. This means that they were not at all free to profess their personal opinions in the états and to vote as they deemed appropriate. Instead, they were bound by written instructions, ${ }^{31}$ drawn up by the electoral assembly of their respective constituency, ${ }^{32}$ which contained the grievances for which the deputies were to demand redress and the concessions they were authorised to make. The imperative mandate precluded per definition the free deliberations which are deemed necessary for the proper functioning of a parliament in the modern sense, since it also entailed a right of recall where a deputy did not follow the instructions of his constituents: '[s]i le député ne tient pas compte, il peut être révoqué par ses commettants'. ${ }^{33}$

As a consequence, parliamentary immunity was impossible in this system, as far as it is understood as being for the protection of free parliamentary deliberations, also shielding members from their electorate. In other words, the system of representation itself, providing for the immediate accountability of the

few women of the second estate (nobility) enjoyed the right to vote; no corresponding exception existed for the tiers.

29 Duverger 1991, p. 23.

30 On the importance of the nature of the parliamentary mandate and the bearing it has on the theory of parliamentary immunity, see part II of the current chapter.

These instructions were called cahiers de doléance (books of complaint).

Members representing the first and second estate were elected per baillage (bailiwick) while the election procedure for members of the tiers differed between rural communities (baillages, paroisses) and the cities. In the countryside, depending on the size of the constituent community, two hundred households (feux) or less elected two deputies, less than three hundred elected three, etc. In the cities, the different guilds and crafts formed constituencies which elected certain numbers of deputies depending on the number of their members. Citizens of cities who were not comprised in any of these professional communities but who were eligible to vote (i.e. they were French, male, at least 25 years old and paid taxes) then formed 'rest-constituencies' who also elected a certain number of deputies, depending on the number of electors. See Art. XXIV et seq. of the règlement électoral. Duverger 1991, p. 23 
members of the estates general vis-à-vis their constituents, stood in the way of basic parliamentary non-accountability, and did so quite independently of any considerations regarding the relationship between the états and the monarch.

\subsection{The Emergence of Immunity in the Revolution}

\subsubsection{Minimal Privilege under the Ancien Régime}

In principle, members of the pre-revolutionary états généraux cannot be said to have enjoyed any form of immunity in the strict sense of protection against the regular application of the law. The 'law' could take the form of a royal lettre de cachet, a directly enforceable order by which the King could cause the arrest or impose any punitive measure against any person in his realm. In short, the law was what pleased the King, without exception. In this sense, the very nature of the absolute monarchy precluded the existence of any immunity, except that of the King himself, who was by definition not subject to the law. ${ }^{34}$

However, the états were one of the assemblies which had evolved out of the medieval curia regis and together formed the conseil $d u$ roi, so the deputies were considered members of the latter organ and therefore enjoyed a special status as advisors of the King. This status did entail certain privileges. However, these were minimal, essentially limited to a suspension of trials ${ }^{35}$ against members of the états in the 15 days prior to the beginning of the session, the duration of the session itself, and the 15 days immediately after the end of the session, although always subject to a ruling by the conseil d'état, which could override the suspension. ${ }^{36}$

The similarity between the privilege of the French conseillers $d u$ roi and that of the members of the early English curia regis is conspicuous. However, the fact that in France this privileged status did not evolve along the same lines is readily explained by the different routes the two countries took in their constitutional development. In England the very origins of parliamentary privilege can be traced to the special status which royal advisors enjoyed under the pax regis. Privilege then evolved, in the wake of Magna Carta and due to a great and lasting dependence of the King on an increasingly assertive parliament. It became a body of law with parliament itself as its institutional base. Such an institutional shift never occurred in France, where the rare and instrumental use of the états généraux by the King eventually made it succumb completely to absolutism.

Consequently, when the états généraux were finally reconvened on the eve of the French Revolution, their self-image still adhered to a traditional, monarchical concept of representation. ${ }^{37}$ This entailed that, as advisors to the monarch, the

34 With the exception of the theoretically existing 'fundamental laws of the kingdom', see the discussion of the institution of parlement above.

35 It may be assumed that these did not include measures of prosecution ordered by the King himself by means of letter de cachet.

36 Guérin-Bargues 2011, p. 24.

$37 \quad$ Ibid. 
deputies only enjoyed a minimal degree of protection which also ensued from his immunity and not, crucially, from any immunity attached to their own institution.

As has been explained above, there was also no form of non-accountability of members of the états vis-à-vis their constituents in the sense of freedom of speech and a free vote, independent of the cahiers de doléance. Deputies who did not speak or vote in accordance with the imperative mandate, which was the basis of their membership in the états, could theoretically be recalled by their constituents who had sent them to the capital to speak in their place and who paid for their expenses.

\subsubsection{The National Assembly}

On 17 June 1789, the third estate, together with a number of clergymen and nobility who had accepted the invitation of the tiers to join its sessions, adopted the name Assemblée Nationale, reasoning that its members represented at least 96 per cent of the nation. ${ }^{38}$ In an effort to contain the revolutionary momentum which was building up within this new National Assembly, the King tried to prevent its session of June 20 by closing the assembly hall, under the false pretence of necessary construction works in preparation of the lit de justice to be held on 23 June. ${ }^{39}$ This led to the well-known serment $d u$ Jeu de Paume, in which the members of the National Assembly, provisionally convened in the Palace's tennis hall, declared themselves la constituante, the constituent assembly of France, by taking the famous oath not to dissolve the assembly and to convene wherever necessary until a constitution had been adopted for the kingdom:

'L'Assemblée Nationale [...] [a]rrête que tous les membres de cette Assemblée prêteront, à l'instant, serment solennel de ne jamais se séparer, et de se rassembler partout où les circonstances l'exigeront, jusqu'à ce que la Constitution du Royaume soit établie et affirmie sur des fondements solides' ${ }^{40}$

\subsubsection{The Earliest Immunity Provisions}

It is apparent from the wording of the oath of the tennis hall that the National Assembly was not yet, at this early stage, pursuing any plans to do away with the monarchy as such (after all they vowed to give a constitution to the kingdom). Rather, it was only to limit its absolute power by embedding it into a binding constitution. It is clear that the limited protection enjoyed by the deputies as advisors to the King had already become all but meaningless.

On the one hand, by declaring itself the National Assembly and by assuming the role of constituante, the legal foundation of this royal protection, the status of members of the estates as conseillers $d u$ roi, had already been undermined, because, both in its actions and in its self-image, the National Assembly was clearly no longer

38 See the Histoire résumée de l'Assemblée Nationale, published on the website of the National Assembly.

$39 \quad$ Guérin-Bargues 2011, p. 27.

40 As quoted in Buchez \& Roux 1834, p. 3. 
an advisory body. On the other hand, the members of the tiers had already begun to openly oppose the wishes of the monarch and continued to do so. On 23 June, the King rejected the act by which the tiers had declared itself the National Assembly, and ordered it to meet separately from the two privileged estates. But the Assembly no longer obeyed him. 'We are here by the will of the people and we will leave only by the force of bayonets' 41 - the words with which Mirabeau is said to have refused to receive the order of the King have become famous; the reference to the will of the people, used to refute the order of the monarch, marks the definite departure from absolutism.

This open disloyalty to the King did not only make it impossible for the members of the National Assembly to rely on his protection, but also made direct attacks by the royal apparatus on members of the National Assembly very likely. The need to protect members of the National Assembly from royal interference had suddenly become most acute. During the session which saw the dismissal of the bearer of the royal order to convene separately, guards of the royal corps were already lining up outside the Assembly Hall and it was believed that 60 members would be arrested the following night. ${ }^{42}$

This is the historical context in which the adoption of Mirabeau's motion to introduce immunity on 23 June 1789 became one of the first 'acts of national sovereignty'. The motion was introduced as follows:

'C'est aujourd'hui que je bénis la liberté de ce qu'elle mûrit de si beaux fruits dans l'Assemblée Nationale. Assurons notre ouvrage, en déclarant inviolable la personne des députés aux États généraux. Ce n'est pas manifester une crainte: c'est agir avec prudence; c'est un frein contre les conseils violents qui assiègent le trône' ${ }^{43}$

That the primary aim of the motion was merely to pre-empt the influence of aggressive advisors 'besieging the throne' is doubtful. Despite Mirabeau's assertion that declaring the deputies immune 'is not a manifestation of fear', it is almost certain that the imminence of reprisals by the royal executive was the primary motive for adopting an immunity regime. Therefore, it was a circumstantial and reactive measure directed against an imminent and tangible threat.

The National Assembly adopted Mirabeau's motion by a majority of 493 votes to $34^{44}$ and established the immunity of each individual deputy by the following decree: probably not used these exact words.

$42 \quad$ Soulier 1966, p. 14 (citing Michelet 1889, p. 174-175).

43 Minutes of the National Assembly, session of 23 June 1789, as quoted by Soulier 1966, p. 13. See also: website of the National Assembly, <http://www.assembleenationale.fr/histoire/mirabeau.asp\#>. Soulier 1966, p. 13. 
'L'Assemblée Nationale déclare que la personne de chaque député est inviolable; que tous particuliers, toutes corporations, tribunal, cour ou commission qui oseraient, pendant ou après la présente session, poursuivre, rechercher, arrêter ou faire arrêter, détenir ou faire détenir un député, pour raisons d'aucunes propositions, avis, opinions, ou discours par lui faits aux États généraux; de même que toutes personnes qui prêteraient leur ministère à aucun desdits attentats, de quelque part qu'ils fussent ordonnés, sont infâmes et traîtres envers la Nation, et coupables de crime capital. L'Assemblée Nationale arrête que dans les cas susdits, elle prendra toutes les mesures nécessaires pour rechercher, poursuivre et punir ceux qui en seront les auteurs, instigateurs ou exécuteurs' ${ }^{4}{ }^{4}$

The wording of this decree leaves no doubt that the meaning which the assembly members attached to the term inviolabilité at the time conforms more to what we understand today as non-accountability:

'any individual, body, tribunal, court or commission that dares, during or after the present session, to prosecute, search, arrest or order to arrest, detain order to detain a deputy for any proposition, opinion or speech uttered by him in the Estates General' was declared 'dishonourable and a traitor to the nation',

as was anyone who would lend their faculty to such an offence. However, the scope of the decree was limited to speech in the états généraux; it did not touch upon anything that happened outside of it.

The second layer of immunity - the one currently referred to as inviolability was only added by a decree of 26 June 1790 which completed the picture of the French two-tier system of parliamentary immunity, the essence of which persists to the present day:

'L'Assemblée Nationale [...] déclare que [...] les députés de l'Assemblée Nationale peuvent, dans le cas de flagrant délit, être arrêtés conformément aux ordonnances, qu'on peut même $[. .$.$] recevoir des plaintes et faire des informations contre eux, mais$ qu'ils ne peuvent être décrétés par aucuns juges, avant que le corps législatif, sur le vu des informations et des pièces à conviction, ait décidé qu'il y a lieu à accusation'. ${ }^{46}$

This decree set limits for judicial action against members of the Assembly beyond the scope of utterances in debates. While charges against them were admissible and judicial enquiries allowed, they could only be arrested if caught in the act, and never sentenced by any judge 'before the legislative body has, on the basis of enquiries and evidence, decided that there is reason for indictment'.

It is particularly interesting to trace the historical circumstances which led to the adoption of the latter decree. Guérin-Bargues observes that it followed - and was indeed directly instigated by - the arrest of the deputy de Lautrec, who had been suspected of counter-revolutionary activities by the municipality of Toulouse. ${ }^{47}$ The rapporteur $d u$ Comité des recherches, Voidel, was of the opinion that

45 Décret du 23 Juin 1789 sur l'inviolabilité des députés

46 Décret du 26-27 Juin 1790 qui règle provisoirement les cas où les députés à l'Assemblée Nationale peuvent être arrêtés, et la forme des procédures à faire contre eux.

47 Guérin-Bargues 2011, p. 99. 
Lautrec did not enjoy the protection prescribed by the decree of 13 June 1789 . Crucially, he did not reach this conclusion by reference to the fact that the alleged activities had been performed outside the scope of Lautrec's mandate (thus rendering the decree inapplicable to his case). It was by concluding that Lautrec's situation differed from that to which the decree applied, in that Lautrec had been legally indicted, proceedings had commenced, and a warrant had been duly issued. He argued that the advanced stage of proceedings rendered the application of the decree of 13 June 1789 unnecessary..$^{48}$ The Assembly took the opposite view - that the first immunity decree of 23 June 1789 did in fact apply in this case - and ordered the release of deputy Lautrec. ${ }^{49}$

Guérin-Bargues draws a conclusion from this episode about the intention of the Assembly in subsequently issuing the second immunity decree of 26 June 1790. It was not to create a new layer of immunity which had not existed previously, but to reiterate and interpret the content of the decree of 23 June 1789, which in the Assembly's opinion had already merited the release of Lautrec. ${ }^{50}$ Her argumentation, based on transcripts of debates in the Assembly, seems convincing. ${ }^{51}$ If it holds true, however, that the decree of 26 June 1790 was intended only as a restatement, necessitated by circumstances of the immunity established previously, this must change our reading of both decrees. It means that (a) the immunity created by the first decree was in fact meant, seemingly in contrast to its wording, to cover extra-parliamentary activities including acts other than utterances, and that (b) it was not the intention of the Assembly to create a new, further-reaching layer of immunity (id est, inviolability) by issuing the second decree. Such a reading would have a significant impact on both our interpretation of the contents of parliamentary immunity as it was designed during the Revolution (to be discussed further below) and on our assessment of the theoretical foundations on which French doctrine traditionally bases the system of inviolability.

In practice, however, the two immunity decrees of 1789 and 1790 in conjunction have formed the historical basis of the French two-tier immunity system: no member of the legislature could be arrested or subjected to any measures of investigation or prosecution for his utterances or the vote cast in the assembly. For punishable acts committed outside the scope of the mandate of a deputy, he could be arrested flagrante delicto. Measures of investigation and legal complaints against him were also permitted, but he could not be detained without a decision to that effect having been taken by the legislative body, following its own examination of the evidence against him. The decision to put a member of the corps législatif in a state of accusation was thus an exclusive right of the assembly.

The first codification of immunity in formal legislation (id est, not by decree) added clarification as to its temporal scope. Pursuant to Article 51 of the loi of 13-17 June 1791, the representatives of the nation were 'inviolable' as of the

48 Ibid. For an account of the facts which led to Lautrec's arrest, Guérin-Bargues refers to A.P., 1 ère série, t. XVI, p. 458-459 [session of 25 June 1790].

Ibid.

Ibid.

Other authors do not share her opinion; see e.g. Soulier 1966. 
announcement of their election, during the entire legislative term and the month immediately after the end of that term. Further, pursuant to Article 53 of the same Act, a representative could be arrested flagrante delicto or on an arrest warrant, but his prosecution could not be continued until the legislature had decided that there was reason for his indictment. The French original of these two articles reads as follows:

'Art. 51: Les représentants de la Nation sont inviolables depuis le moment de leur élection proclamé, pendant toute la législature dont ils sont membres, et en outre, pendant un mois à compter de cette législature.

Art. 53: Ils pourront, pour faits de crimes commis hors de leurs fonctions, être saisis soit en flagrant délit, soit en vertu d'un mandat d'arrêt; mais la poursuite ne pourra être continuée qu'après que le corps législatif aura déclaré qu'il y a lieu à accusation' ${ }^{52}$

The adoption of the Act of 13-17 June 1791 brought the first stage of the development of French parliamentary immunity to an end: it consolidated the immunity system which had been created ad hoc by the National Assembly. What is remarkable about these statutory provisions is that they did not seem to contain a reference to non-accountability (in the modern sense) - only inviolability for crimes committed outside the sphere of the legislative mandate was explicitly regulated in Article 53. This should not be taken to mean that non-accountability was not intended by the legislator. Not only would that be illogical in the presence of inviolability for extra-parliamentary crimes, it would also be inconsistent with the opinio iuris of the National Assembly, both prior to the adoption of the Act (as expressed in the two decrees discussed above), and immediately afterwards, when the first republican constitution was adopted on 3 September 1791. Therefore, a more convincing interpretation of the Act of 13-17 June 1791 seems to be that nonaccountability was, for a reader at that time, so obviously included in the members' inviolabilité that an explicit, separate mention of it was deemed unnecessary.

It should also be noted that the immunity provisions in the Act of 13-17 June 1791 did not provide for a comprehensive freedom from arrest: as long as an arrest was carried out flagrante delicto or on a valid arrest warrant, a representative of the nation could indeed be deprived of his liberty, at least until the legislature had decided not to allow his prosecution to continue. The immunity provisions focused much more on due observance of procedure in prohibiting arbitrary arrests and they required that the deputy concerned be actively indicted by the legislature after the arrest in order for the prosecution to continue. This must, again, be taken to have applied only to cases involving alleged criminal acts outside the scope of the legislative mandate; in the context of the decrees of 1789 and 1790 and the Constitution of 1791, arrest and prosecution for utterances in the Assembly are likely to have been prohibited in general. 
The Constitution of 1791 contained two articles with wording very similar to that of the statutory provisions discussed above. However, both layers of immunity are now explicitly recognisable: non-accountability was laid down in Title III, Chapter I, section 5, Article 7, which provided that the representatives of the nation could not be investigated, charged or condemned at any time for what they had said, written or done in the exercise of their function as representatives:

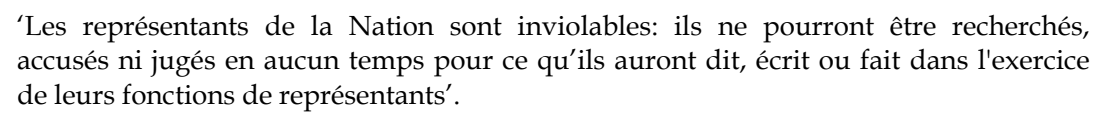

An interesting feature of the first constitutional non-accountability provision is the incorporation of acts ('what they have done') other than utterances, whereas the decree of 23 June 1789 had still spelled out 'propositions, advice, opinions or speech' uttered in the Assembly as the material scope of non-accountability. If the new wording meant more than simply a more concise formulation, it is unclear which acts precisely the drafters of the constitution had in mind, but it seems unlikely that they actually intended to broaden the scope of non-accountability.

The second layer of immunity, inviolability, was laid down in Article 8 of the same section, and added a degree of procedural precision to the wording of Article 53 of the Act of 13-17 June 1791. It stipulated that representatives could be arrested for criminal acts, either flagrante delicto or upon an arrest warrant, but that the legislative body had to be notified of such an arrest without delay. As under the Act of 13-17 June, the prosecution was not allowed to continue unless the legislature decided that there was reason for indictment:

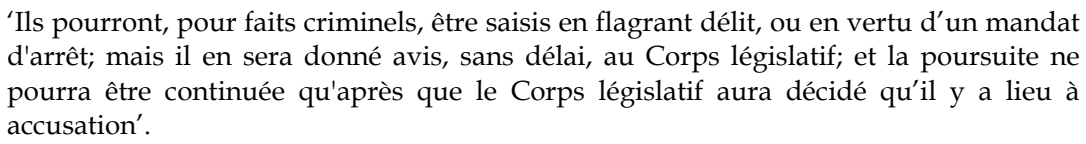

\subsubsection{Two Possible Interpretations of the Emergence of Immunity}

The wording and legislative expression of parliamentary immunity have been subject to considerable change since its first emergence in 1789 , but the system on the whole displays a remarkable degree of continuity. This is true for its content and structure: a two-tier system which provides members of the legislature with nonaccountability for utterances and acts associated with their legislative mandate. Also, doctrine has traced the theoretical justification of immunity back to its historic origin, laying a justificatory link between the alleged necessity of, in particular, inviolability, and the concepts of national sovereignty and the representative legislative mandate, as opposed to the imperative mandate which the members of the états généraux received from their constituents. In order to facilitate a later evaluation of the doctrinal base of immunity, it is necessary to have a closer look at the possible interpretations of the first immunity provisions and their emergence in the context of the French Revolution. 
Different interpretations are conceivable for several aspects of the earliest immunity provisions. First, the establishment of what the National Assembly then called the 'inviolability of its members' can be understood in two ways, a more abstract one and one which can be called historic realism. Traditionally, doctrine holds that its emergence in the very first days of the Revolution was a logical and necessary consequence of the shift from absolute royal sovereignty to national sovereignty realised through representation. ${ }^{53}$ The argument is that, in order to allow for the will of the (abstract) sovereign nation to manifest itself in its representatives, these must be protected from any interference. ${ }^{54}$ National sovereignty therefore cannot exist without the full set of immunities, id est, both non-accountability and inviolability, because only together can the integrity of the body representing the nation be safeguarded..$^{55}$

The historic realist interpretation ${ }^{56}$ focuses more on the revolutionary context and seeks to explain the emergence of immunity by reference to historical circumstances: the members of the National Assembly, openly opposing the king, feared serious reprisals by the executive. The adoption of the decree of 23 June 1789 was directed solely against the executive and motivated by an acute threat perceived by the Assembly. Similarly, the adoption of the decree of 26 June 1790 was merely circumstantial, a reaction to events which urgently required measures to be taken.

These interpretations are not necessarily irreconcilable, in so far as we do not attach too much importance to the question of which view is correct on the cause of the establishment of immunity. Even if the motivation of the National Assembly to issue the two decrees establishing immunity was merely circumstantial, this does not mean that it was not also necessary to do so from a theoretical point of view. However, the adoption of either view can have far-reaching consequences for the assessment of, in particular, inviolability (in the modern sense, of a far-reaching immunity for acts committed in the extra-professional sphere). If we assume that the establishment of this second layer of immunity was merely circumstantial and that it is not at least also a necessary consequence of the idea of national sovereignty, this would considerably weaken the justification of inviolability in the constitutional system.

It is therefore interesting to further examine the interpretation which the National Assembly itself attached to the immunity system it first created in its decrees of 23 June 1789 and 26 June 1790. Is it true that the first decree was only intended to create basic non-accountability and that the second decree established

53 We will discuss the details of this line of reasoning in section 3 of this chapter.

54 An immunity based on this thought is akin, though not identical, to that enjoyed by the absolute monarch before the Revolution. In absolutism, the monarch could not be subject to the law since, as the sovereign, his will was identical with the law. The comparison is impure, since the National Assembly did not claim to be but to represent the sovereign nation.

55 This argumentation, in much more detail, can be found in most works on French parliamentary immunity, of which the most comprehensive to date is still the work of Soulier 1966.

56 Proposed recently by Guérin-Bargues 2011. 
inviolability as a second layer of immunity? First, it is certain that the drafters of the two decrees did not differentiate between non-accountability and inviolability as distinct concepts. ${ }^{57}$ Whereas the wording of the decree of 23 June 1789 suggests an interpretation of the term 'inviolabilité' as non-accountability, a wider interpretation has also been proposed. 58

According to Guérin-Bargues, a wider interpretation is corroborated by a number of historical leads, such as the answer Mirabeau gave to a member who opposed the adoption of the decree of 23 June 1789, because the establishment of immunity would mean 'to arrogate an exclusive privilege, whereas all citizens have the same right to the security we claim'. ${ }^{59}$ Mirabeau responded that 'undoubtedly all citizens must be protected from arbitrary imprisonment; but the deputies are the only ones who must not be investigated during the session, even where this would be done in a legal manner' ${ }^{60}$ If this was the opinion of the majority which adopted the decree, the intention must indeed have been to establish a wider immunity than mere non-accountability and, in its own view, this was then also what the National Assembly had done.

Guérin-Bargues also found in the parliamentary archives a version of the decree of 23 June 1789 which contained a paragraph providing that 'toutes poursuites, civiles et criminelles' against members of the National Assembly are prohibited unless they are explicitly authorised by the assembly. ${ }^{61}$ Thus, apparently the term 'inviolabilite' was understood by the drafters of the decree as meaning a broad immunity, covering both utterances and acts within and outside the scope of the legislative mandate. This would also justify the proposition, explained earlier, that the decree of 26 June 1790 should be understood as a mere reiteration, or a specification at most, of the decree of 23 June 1789.

In conclusion, both the drafting process and the content value of the first immunity provisions can be interpreted in different ways. While the interpretation of the former depends on whether one assumes a more abstract, theoretical perspective or a historic realist view of the revolutionary events, the interpretation of the latter largely depends on whether one adopts a purely literal or a more contextual reading of the two decrees. The ambiguous term 'inviolabilité" in the earliest immunity provisions should very probably be read as having a similar content value as it has today, while also covering non-accountability.

It is important to bear this in mind when discussing the relationship between the conception of national sovereignty, the representative legislative mandate and parliamentary immunity (part three of this chapter).

Guérin-Bargues 2011, p. 96.

Soulier 1966, p. 14; Guérin-Bargues 2011, p. 96 et seq.; Duez 2004, p. 569.

As quoted by Guérin-Barges 2011, p. 97 (my translation).

Ibid. (author's translation).

Ibid., note 8 . 


\subsection{The 'Waltz of Constitutions' ${ }^{62}$}

Between 1789 and today, France has had a multitude of constitutions. The exact number depends on what one accepts as a constitution. An example is whether the Charter of 1815, in force during the 100 days reign of Napoleon after his return from exile on Elba, and formally only an amendment to the Charter of 1814, is counted as a proper constitution. But it is safe to say the number of constitutions amounts to more than eight. While the wording of the immunity provisions contained in these constitutions $^{63}$ varies considerably, the principal features of the two-tier immunity system of non-accountability and inviolability are a recurring theme. Not all constitutions contained both elements of this two-tier system, especially in the autocratic, non-republican periods of the $19^{\text {th }}$ century, but the idea of both immunities has resurfaced, time and again, with the adoption of a new system.

It cannot be said that the multitude of immunity provisions French parliamentarians have seen during the 'waltz of constitutions' have had a decisive impact on the doctrine of parliamentary immunity - which usually refers to the origin of immunity in the Revolution. An all too extensive treatment of the details of the immunity regimes under all these constitutions is thus not necessary for the purposes of this study. It will consequently be omitted where it does not contribute to a better understanding of parliamentary immunity: instead, a short account of the respective constitutional systems and their immunity provisions will be given in order to illustrate the continuity of the fundamental idea of parliamentary immunity, and to provide the necessary historical background for an examination of the system as it applies in the Fifth Republic.

\subsubsection{The Period of the National Convention}

The development of the immunity regime during the years of the National Convention (21 September 1792 - 26 October 1795) is most interesting. It illustrates the limitations of the possibility to protect parliamentarians, and parliament as an institution, in a situation in which the rule of law is all but absent, and in which any system of legal protection is therefore ineffective.

The factual circumstances and subsequent legal provisions which effectively abolished both components of the immunity regime (but especially inviolability) during that time have subsequently been taken back. This has characterised the time of the Convention in essence as an interruption rather than a stage in the development of parliamentary immunity in its own right. The fact that, and the

Duverger 1991, p. 34

63 Not all of them did contain immunity provisions. The constitution of 1852, establishing the second French Empire, did not provide for any immunity, although two (very weak) parliamentary Chambers (Sénat and Corps Législatif) existed under the Empire. The full text of the constitution of 1852 is available on the website of the Conseil Constitutionnel. Several other documents which are occasionally counted as constitutions are de facto only far-reaching amendments of previous constitutions and did not contain immunity provisions as they left the unamended parts of the previous constitutions intact. 
manner in which, the immunity provisions lost their effect nonetheless teaches us an important lesson about the mechanisms of any immunity regime - especially about its shortcomings.

On 10 August 1792, the masses of Paris stormed the Tuileries, the seat of the legislative assembly provided for by the Constitution of 3 September 1791, demanding the end of the monarchy. Subsequently, the legislative assembly suspended the monarchy, decreed its own dissolution, and the election by universal (male) suffrage ${ }^{64}$ of a National Convention tasked to draft a new constitution for France. After these elections had taken place, the National Convention held its first session on 20 September 1792. The next day, it abolished the monarchy, thus creating the first French Republic.

The National Convention did proceed with the drafting of a new constitution; however, that constitution never entered into force. ${ }^{65}$ Instead, the Convention, initially intended to function as a (constitutional) legislator, assumed executive power as well, which it exercised through several committees, most notably the committee of public welfare (comite de salut public) and the committee of general safety (comité de sûreté générale). In doing so, the Convention acted in direct contravention of the ideas which formed the theoretical basis of the Revolution, in particular the Montesquieuvian idea of the separation of powers.

The period of the National Convention was marked by the grande terreur, the terror regime during which, between the summer of 1793 and the summer of 1794, tens of thousands of death sentences were handed down - and executed - for alleged counter-revolutionary activities.

The system of immunity of members of the legislature, established by the National Assembly and enshrined in the Constitution of 1791, was not formally abolished during the rule of the Convention. However, it was subject to serious assaults and, for all practical purposes, was not observed. This is particularly true for the time of the grande terreur. On the first of April 1793, the Convention adopted the following decree upon the proposition of Marat:

The National Convention, considering that the well-being of the people is the supreme law, decrees that, notwithstanding the inviolability of a representative of the French Nation, it will order the indictment of those of its members against whom there are grave presumptions of complicity with the enemies of freedom, of equality and of the republican form of government, resulting from denunciations or from written evidence submitted to the committee of general defence [later: committee of general safety],

64 As opposed to suffrage under a census, as it had been provided for in the constitution.

65 Constitution of 24 June 1793 (Under the revolutionary calendar which the national convention adopted in 1793 and which declared the day following that of the deposition of the King the $1^{\text {st }}$ Vendemière of year one, this constitution is referred to as la constitution de l'an I). Having been drafted and approved by referendum in times of war and a general national crisis, the constitution never entered into force. Ironically, the constitution of the year one would have been much more democratic than the one of 1791 and the one of 1795 (constitution de l'an III); amongst other things, it would have provided for universal suffrage without a census. As regards immunity, the constitution of the year one would have maintained non-accountability and inviolability along the lines of the previous constitution (Arts. 43 and 44). 
which shall be responsible for matters relating to orders of indictment to be issued by the Convention. ${ }^{6}$

The effect of this decree is striking: not only could the immunity of members be lifted by the Convention (which had always been the case), it was now automatically rendered inapplicable to any member against whom there were presumptions of complicity with counter-revolutionary activities or persons. And the mere denunciation of a member was already sufficient to give rise to such presumptions. Further, the decree not only lifted a member's immunity, allowing the arrest of a member, it also automatically put the member concerned in a state of accusation.

After the period of terreur had begun, concerns about the negative effects of the above decree seem to have increased among the members of the Convention. They tried to mitigate the automatisms described by adopting, on 10 November 1793, a decree which provided that members could not be arrested before being heard by the Convention. ${ }^{67}$ However, this decree was taken back only two days later, justified as being done for 'the national interest, the justice owed to the people and the principle of equality' ${ }^{68}$ The period of terreur culminated in the adoption, by the Committee for Public Welfare (comite de salut public) of the law of 10 June 1794 (22 prairial of year II under the new revolutionary calendar). This law aimed at simplifying the proceedings of the revolutionary tribunal and at making trials more expedient. It limited the tribunal to only two possible judgments: acquittal or death. ${ }^{69}$ It also provided for a 'definition' of the punishable counter-revolutionary crimes, which was so broad that a guilty verdict was all but inevitable. ${ }^{70}$ At the same time, it obliged citizens to denounce conspirators and counter-revolutionaries ${ }^{71}$ and denied the accused the right to counsel. ${ }^{72}$

On the day after the adoption of the law of 10 June 1794, the members of the Convention tried to exclude themselves from its application, by decreeing that, 'by yesterday's decree concerning the revolutionary tribunal, [the convention] did not intend to derogate from laws which prohibit the committal to the revolutionary tribunal any representative of the people against whom no decree of accusation has

66 As quoted by Soulier 1966, p. 15 (my translation). The French original reads as follows:

'La Convention nationale, considérant que le salut du people est la suprême loi, décrète que, sans avoir égard à l'inviolabilité d'un représentant de la nation française, elle décrètera d'accusation celui ou ceux de ses membres contre lesquels il y aura des graves présomptions de complicité avec les ennemis de la liberté, de l'égalité et du gouvernement républicain, résultant des dénonciations ou de preuves écrites déposées au Comité de défense générale, chargé des rapports relatifs aux décrets d'accusation à lancer par la Convention'.

Soulier 1966, p. 15

Ibid. (author's translation).

Law of 22 prairial of year II, Art. 7.

Ibid., Arts. 5 and 6.

Ibid., Art. 9.

Ibid., Art. 16. This article is particularly cynical, as it states that 'slanderously accused patriots are provided with patriotic jurors as defenders. None are provided to conspirators', thus making the condemnation of any accused person in advance practically explicit. 
been issued previously' ${ }^{73}$ However, the de facto dictatorial Committee of Public Welfare retracted this decree the next day. ${ }^{74}$

During the period of terreur, a multitude of members of the Convention - and finally also the group around Robespierre that had designed the law of 10 June 1794 - were sentenced to death by the revolutionary tribunal and executed. As has been mentioned previously, the period of the National Convention should not be seen as a stage in the development of immunity but as a phase during which exceptional circumstances led to its suspension. The period may serve as one of the most extreme illustrations of the limitations of parliamentary immunity and the protection it can offer. It shows that any immunity fails to fulfil its purpose where its guarantees cannot be relied upon against those in power, for example, under a dictatorial regime, in a state of lawlessness or in another situation in which fundamental constitutional guarantees and the rule of law are either abused or disregarded. In other words, any legal immunity still requires that the law be observed, and not abused, by the persons or institutions in power.

Another interesting aspect which can be observed when looking at the period of the National Convention is that the decrees of 1 April and 12 November 1793 suspend the immunity regime with reference to, amongst others, the principle of equality. While this principle, understood as equality before the law, is rendered de facto meaningless in times where no legal guarantees exist, these references do hint at the fundamental dilemma which arises in the context of parliamentary immunity - the clash of two constitutional principles of the same order. ${ }^{75}$ While it is certain that the motives for the suspension of immunity during the time of the National Convention was not based on such theoretical considerations, it serves to draw our attention to the problem of invoking one constitutional principle against another, which will be discussed further in part three of the current chapter.

\subsubsection{The Constitution of Year III}

After the fall and execution of Robespierre and other prominent figures who had overseen the reign of terror, a commission of 11 members of the National Convention was charged with drafting a new constitution, as the Convention now rejected the idea of a late entry into force of the Constitution of year I.

On 22 August 1795 (5 fructidor of year III), the new constitution was approved by the Convention. In a subsequent popular referendum it was also accepted by the French people. It entered into force on 23 September 1795 (1 vendémaire of year IV).

The new constitution re-introduced a clear separation of powers. However, it was one which came at the price of a political deadlock, as Martin and Cabanis explain: '[...] the members of the constituante [...] tried to fragment power in order to avoid tyranny both of the executive and of the legislature. In the end, they achieved nothing but a system which favoured immobilism and corruption' ${ }^{76}$

Soulier 1966, p. 16 (author's translation).

Ibid.

This has also been observed by Soulier 1966, p. 56 et seq. and other authors.

Martin \& Cabanis 2000, p. 19. 
Indeed, the constitution contained many safeguards against tyranny, but no mechanism for the resolution of inter-institutional conflict, which made its application cumbersome.

The Constitution of year III provided for a bicameral legislature consisting of a Council of Five Hundred 77 and a Council of Elders. ${ }^{78}$ Membership of either body was incompatible with any other public office. ${ }^{79}$ A third of both assemblies, respectively, was to be elected each year by a body of electors (itself composed of members elected by so-called Primary Assemblies; regional gatherings of citizens eligible to vote). The executive consisted of five so-called Directors ${ }^{80}$ (the period during which the constitution of year III was in force is also referred to as the time of the directoire) and a number of ministers appointed by the Directorate. The Directors were chosen by the Council of Elders from a list of candidates drawn up by the Council of Five Hundred from among the former members of the legislature and the former ministers. ${ }^{81}$ The term of office of the Directors was five years. They could not be re-elected for a period of five years following the end of their term. Furthermore, one Director was to be replaced each year (during the five years following the entry into force of the constitution, the order by which the Directors were replaced was determined by a ranking among the members of the first Directorate).

The legislative procedure provided for an equilibrium of powers between the two chambers of the legislature (and for the possibility of a complete dead-lock). It also strictly adhered to the principle of separation of powers. Bills were introduced to the Council of Five Hundred by one or more of its members and, if adopted, transferred to the Council of Elders as resolutions. In order to enter into force as lois,

Constitution of year III, Arts. 73-81.

Ibid., Arts. 82-109.

Ibid., Art. 47.

Ibid., Arts. 132-173.

Ibid., Arts. 135 and 136. Pursuant to Art. 135, the requirement of formerly having been a minister of member of the legislature was only to be applied as of the ninth year of the republic (i.e. the fifth year from the entry into force of the constitution). However, as of the fifth year of the republic, current members of the legislature and members whose mandate had expired less than a year ago could not be elected directors (Art. 136). These articles must be read as an emanation of the separation of powers between the legislative and the executive branch; however, they must also be read in the context of the décret des deux tiers, a decree, adopted by the National convention prior to the entry into force of the new constitution, which stipulated that, in the first election of both chambers of the new legislature, two thirds of the members of either chamber had to be elected from among the members of the former national convention. This measure was meant to provide for a degree of political continuity after the introduction of the new system and thus to avoid the events which followed the exclusion of all members of the National Assembly after the entry into force of the constitution of 1791. In fact, the décret des deux tiers effectively imposed the a political majority (that of the drafters of the constitution) on the new legislative institutions. This rule, read in conjunction with the provisions concerning the eligibility criteria for directeurs during the year immediately following the entry into force of the new constitution and, subsequently, five years later, leads to a picture of a composite mechanism designed to exclude certain political groups (the royalists, who opposed the republic) from power, both in the executive and in the legislative institutions. 
such resolutions then had to be adopted by the Council of Elders, which had neither a right of initiative nor of amendment. They were promulgated by the Directorate, which could not refuse to do so without thereby committing an 'attentat contre la sûreté de la République' - an assault on the security of the Republic. ${ }^{82}$

The Constitution of year III must, to a large extent, be read as a reaction to the experience of the period of terror which the Republic had undergone during the time of the National Convention. This is illustrated, on the one hand, by the many provisions the constitution included as precautions against a usurpation of power by the directoire, and on the other hand, by the number and the degree of precision of its provisions on legislative immunity. The members of the Directorate disposed of the armed forces but were not allowed to command them directly. ${ }^{83}$ They were also not allowed to leave French territory until two years after the end of their term, ${ }^{84}$ nor to be absent for longer than five days from the seat of the Directorate, ${ }^{85}$ from which they could also not remove themselves by more than 40 kilometres without prior authorisation by the legislature. ${ }^{86}$ Thus, the constitution did not only limit the room for political manoeuvre but also the physical freedom of the Directors. This certainly reflects the extreme degree of fear, on the part of the drafters of the constitution, of dictatorial government (and perhaps of foreign conspiracy).

Similarly, it is owing to the proximity of the events during the period of terreur, which the deputies of the National Convention must still have had vividly in mind when drafting the new constitution, that the immunity provisions in the Constitution of the year III were the most detailed than any other French constitution to date. No less than 13 articles ${ }^{87}$ of this constitution stipulated very precisely not only the immunities which members of the corps legislative were to enjoy, but also the procedure which had to be followed for the authorisation of the prosecution of a member, the prosecution itself, and the consequences such proceedings entailed for the mandate of that member. The same immunity regime applied to the members of both chambers of the legislature and, in part, to the members of the directoire. ${ }^{8}$ First of all, Article 110 provided for absolute nonaccountability:

82 Constitution of year III, Art. 104. The role of the directoire in the legislative process was formally limited to this duty to promulgate statutes without objection. However, Art. 63 provided that it could 'invite' the conseil des cing cents to take a certain matter into consideration, however not in the form of presenting it with a legislative proposal.

Ibid., Art. 144.

Ibid., Art. 157

Ibid., Art. 164.

Ibid.

Ibid., Arts. 110-123, 'de la garantie des membres du Corps législatif'

By virtue of Art. 158, Arts. 112-123 applied analogously to the directeurs. They did not enjoy the non-accountability afforded to members of the legislature by Art. 110. This is explicable from a doctrinal point of view, given that the Directoire did not take part in legislative deliberations, i.e. their utterances were not important to the formation of the national will, and thus did not deserve equal protection. 
The citizens who are, or have been, members of the legislative body may not be investigated, accused nor tried at any time for what they have said or written in the exercise of their functions. ${ }^{89}$

Next to this primary layer of immunity, members of both chambers of the legislature as well as the Directors were protected by a remarkably complex system of inviolability. Article 111 of the constitution determined that the scope of this inviolability ratione temporis extended from the moment of their election ${ }^{90}$ up to 30 days after the expiry of their mandate. During this time, members enjoyed freedom from arrest - except flagrante delicto, or where the lifting of inviolability had been proposed by the Council of Five Hundred, and subsequently decreed by the Council of Elders. In case of an arrest flagrante delicto, any further proceedings against the member concerned had to be authorised in the same manner. This means that, irrespective of which chamber the person concerned belonged to, the active consent of both chambers was required in order to instigate judicial proceedings against him, even where he had been arrested flagrante delicto. ${ }^{91}$ If proceedings against a member were authorised, he was to be tried before the High Court of Justice (haute cour de justice), a special, non-permanent court staffed by judges of the tribunal de cassation and several hauts-jurés, jurors elected by the same electoral college as the chambers of the legislature. ${ }^{92}$ The constitution also stipulated explicitly that the same court (and probably, for want of any provision suggesting otherwise, the same authorisation procedure) was to try members of the legislative body and Directors for the crimes of treason, squandering as well as 'manœuvres pour renverser la constitution et d'attentat contre la sûreté intérieure de la République'. ${ }^{93}$ In Articles 116 to 122 of the constitution, details were laid down as to formal requirements for complaints against members (these had to be in writing, signed and addressed to the Council of Five Hundred) as well as the procedure to be followed by the two chambers; amongst others, the accused member had to be heard by both chambers before they took their respective decisions. Article 123 provided that the mandate of a member who had been put in a state of accusation (that is, those whose prosecution had been authorised by the legislature) was suspended and could be resumed if that member was acquitted by the haute cour.

It is readily apparent from the above that the immunity regime provided for by the Constitution of year III was exceptionally elaborate and that the protection it afforded to members of the legislature (and by analogy also to members of the Directorate) was exceptionally strong. It did not, however, deviate in its legislative form and its basic content from the two-tier immunity system established by the first immunity decrees of 1789 and 1790. In effect, just as one can see the period of the National Convention as a historic low point in the effectiveness of immunity but peuvent être recherchés, accusés ni jugés en aucun temps, pour ce qu'ils ont dit ou écrit dans l'exercice de leurs fonctions'.

90 The original French term is 'nomination'. Constitution of year III, Arts. 112 and 113

Ibid., Art. 266.

Ibid., Art. 115 
not as a stage in its development, one may similarly regard the period following the adoption of the Constitution of year III as a particularly high amplitude on an immunity scale, but not one which brought any lasting change to the system. The entire constitution provided for inter-institutional relations marked by a highly accentuated separation of powers and, in particular, for a tightly controlled executive. Much in line with this spirit, the immunity regime of year III is characterised by the inter-institutional distrust which is undoubtedly owed to the experience of terreur. In this sense, later constitutions can be seen as a return to normality.

\subsubsection{The Constitution of Year VIII}

On 9 November 1799 (18 brumaire of year VIII), the constitutional system of the Directorate was overthrown by Napoleon Bonaparte in a coup d'état which abolished the Directorate and installed a nominally three-headed provisional consulate to take its place. It consisted of Napoleon as the First Consul (premier consul) and two others, Sieyès and Ducos, who had been members of the Directorate and had sympathised with a military coup. In reality, however, the First Consul, Napoleon, had assumed near-dictatorial powers which were later formalised in the Constitution of year VIII, adopted on 13 December 1799 (22 frimaire of year VIII).

While an extensive account of the content of this constitution would lead us too far, it is sufficient to say that it provided for the peculiar construction of a tricameral parliament, ${ }^{94}$ consisting of a Conservative Senate (sénat conservateur) of 80 members for life, a Tribunate (tribunat) of 100 members and a Legislative Body (corps legislatif) of 300 members. The members of the latter two chambers were appointed by the Senate, ${ }^{95}$ which itself was a self-replenishing assembly: the first 60 members were picked by the two former, and lesser, consuls of the provisional consulate, Sieyès and Ducos, whom the constitution explicitly assigns with that task, together with the two lesser consuls of the new consulate. Subsequently, the Senate was to elect the remainder of its own members. ${ }^{96}$

Though the constitution re-established universal male suffrage, the influence exercised by the people through elections was extremely limited, since elections only produced lists of notables from which the holders of any public office had to be picked; thus, the people did not bear any immediate influence on national politics. This is all the more true since the constitution prescribed a legislative process in which the government held the sole right of initiative (in which it was assisted by a Council of State, which gave legal advice on bills); bills were discussed in the Tribunate and subsequently voted without debate in the Legislative Body. The

94 It may, however, be seen as inappropriate to refer to the sénat conservateur as a parliamentary chamber, as it does not have a role in the legislative process apart from a constitutionality check. One could, therefore, also speak of a bicameral parliament (tribunat and corps legislatif) and count the sénat as an institution auxiliary to the executive.

95 Constitution of year VIII, Art. 20.

$96 \quad$ Ibid., Art. 24. 
Senate had the right to pronounce on the constitutionality of bills adopted by the Legislative Body as long as they had not yet been promulgated by the First Consul.

The system of immunity laid down in the Constitution of year VIII covered the members of the Conservative Senate, the Tribunate and the Legislative Body as well as the members of the Council of State. It again maintained the two-tier structure of non-accountability and inviolability, the former also covering the consuls. In what appears to be a very remarkable deviation from all other immunity regimes in French constitutional history, the Constitution of year VIII did not, however, provide for freedom from arrest. It did contain an element of inviolability, but that was limited to an authorisation requirement for the prosecution of members of the respective assemblies. The immunity provisions laid down in Articles $69-71$ of the constitution read as follows:

Article 69. The functions of members of the Senate, the Legislative Body and the Tribunate, as well as those of the Consuls and the members of the Council of State do not give rise to any responsibility.

Article 70. Criminal acts [délits personnels] punished with an afflictive or infamous penalty, committed by a member of the Senate, the Tribunate, the Legislative Body or the Council of State, are prosecuted in the ordinary courts after this prosecution has been authorised by a decision of the body of which the accused is a member. ${ }^{97}$

Accordingly, it can be concluded that the protection enjoyed by members of the legislature was indeed considerably more limited under Napoleon's Consulate than ever before since the beginning of the Revolution, with the exception of the period of terreur. The relative loss of protection becomes strikingly evident when compared to the immunity regime under the Constitution of year III, which had provided for a wide inviolability, including freedom from arrest and which had required the authorisation of both legislative chambers for the prosecution of a member of either chamber. The detailed formal requirements for complaints against members of the legislature have also been omitted from the first Napoleonic constitution.

To conclude that the temporary decline of parliamentary immunity under Napoleon was a consequence of the departure from revolutionary ideas would probably be inaccurate - after all, parliamentary immunity was to be restored, more or less, to its revolutionary form during the subsequent monarchies and republics. However, its decline certainly signifies the slowing-down of the revolutionary momentum or, according to some, the end of the Revolution. ${ }^{98}$ It underscores the impression that the Constitution of year VIII, though formally still republican, in fact created a republican façade which concealed the return of certain mechanisms characteristic of the ancien regime, including personal rule and weak representative assemblies wielding very little actual power.

97 For the purposes of both immunities, ministers (whose role was comparable to that of ministers under the constitution of year III) were regarded as conseillers d'état. This follows from Art. 71 of the constitution of year VIII.

98 Martin \& Cabanis 2000, p. 22. 
The system established by the Constitution of year VIII underwent two significant amendments in 1802 and 1804 - equally often referred to as constitutions in their own right, the Constitutions of year X and year XII. The former installed Napoleon Bonaparte as First Consul for life, the second as Emperor of the French. Both documents also introduced other changes of the institutional setup and the functioning of the state, without, however, changing the system of immunity introduced by the Constitution of year VIII.

\subsubsection{The Constitutional Charters of 1814 and 1830}

After Napoleon had been exiled in 1814, the monarchy of the house of Bourbon was restored, however without a return to absolutism. Instead, the Constitutional Charter of 1814 (the restoration brought with it the end of the revolutionary calendar) established a constitutional monarchy in which the King held a strong position. Similarly to Napoleon, he had the sole right to introduce legislative proposals to the bicameral legislature, consisting of a Chamber of Peers (chambre des pairs), which comprised an indefinite number of peers appointed by the King, and a Chamber of Deputies of the Departments (chambre des députes des départements).

The monarchy of the restoration lasted until 1830, briefly interrupted by the Napoleon's return from exile for the period of 100 days during which the empire was restored. In the revolution of July 1830, King Charles $X$ had to abdicate. His successor, Louis XIX, famously reigned for only 20 minutes, before abdicating in favour of Henri d'Artois, the grandson of Charles X, who then became Henri V of France, establishing the July Monarchy (monarchie de juillet). This lasted until 1848 and featured a very similar institutional setup as the monarchy of the restoration, albeit under a new constitution.

The immunity provisions of both constitutional Charters, though numbered differently, were identical. For the Chamber of Peers, Article 34 of the constitutional Charter of 1814 (Article 29 of the Charter of 1830) provided that

No peer may be arrested except by order of the Chamber, and only the Chamber may judge a peer in criminal matters.

For the Chamber of Deputies of the Departments, Articles 51 and 52 (43 and 44) provided that:

No physical restraint may be imposed on a member of the Chamber during the session and within the six weeks preceding or following it.

During the session, no member of the Chamber may be prosecuted nor arrested in criminal matters, except flagrante delicto, without the prior permission of his prosecution by the Chamber.

Several elements of these provisions set the immunity system of the two monarchies apart from those of previous and subsequent constitutions. First, none of these constitutional rules seems to provide for non-accountability, or at least they do not 
do so explicitly. However, members of both chambers were protected from any criminal prosecution, which must be interpreted as including prosecution for utterances in parliament deemed to be of a criminal nature. Nevertheless, even if criminal proceedings for parliamentary speech and other acts related to the mandate of a peer or deputy was thus barred, for the Chamber of Deputies this was only the case during the session and the six weeks preceding and following it. In other words, even if the material scope of non-accountability could potentially be read into the much wider material scope of inviolability, this is not true for the temporal scope which usually renders non-accountability absolute. The immunity system of the two monarchies can thus be said to have limited non-accountability where the duration of the parliamentary session is concerned. ${ }^{99}$

From a doctrinal point of view, this may be explained or justified by the return to royal sovereignty. While the monarch was bound by the constitution and thus did not reign as an absolute ruler, it was once again he, and not the nation, in whose name legislation was passed. From a merely theoretical perspective, the complete and utter freedom of speech, which is held to be a prerequisite for the formation of the national will in legislative debate, was therefore not necessary as a matter of principle.

The second remarkable characteristic of the immunity regime of the monarchies was that the inviolability afforded to the members of the Chamber of Peers was considerably stronger than that granted to the Deputies. On the one hand, the inviolability of the peers did not have the exception of an arrest flagrante delicto. On the other hand, while a member of the Chamber of Deputies could, during the session, only be prosecuted with the permission of the Chamber but was then tried before an ordinary court, a peer was protected from ordinary criminal justice for life; he could only be judged by his chamber, which then acted as a court. 100

\subsubsection{The Constitution of 1848}

The July Monarchy ended with the Revolution of 1848, which led to the election of a new constituent National Assembly, assigned with the task of drafting a new constitution. This constitution was finally adopted by the assembly and entered into force on 4 November 1848. It established the second French republic, in which sovereignty rested with 'the entirety of the French people'. ${ }^{101}$ In turn this delegated legislative power to a unicameral parliament, the Assemblée Nationale, ${ }^{102}$ elected for three years by universal (male) suffrage. Executive power was vested in a president of the republic, elected by the people for a term of four years (renewable after an

99 For the chambre des pairs, however, this was irrelevant, since they were appointed for life.

100 It is of interest that, in several respects, the chambre des pairs resembled the British House of Lords, membership in which (peerage) is also granted by the monarch either for life or (formerly) even as a hereditary right and which also held judicial functions (and continues to do so as regards parliamentary privilege).

101 Art. 1 of the constitution of 1848

102 Ibid., Art. 20. 
interval of one term) and was equipped with the right of legislative initiative as well as the right to demand a renewed deliberation of bills by the assembly, before promulgating laws 'in the name of the French people'. ${ }^{103}$

In the Second Republic, the constitutional provisions on parliamentary immunity almost reached their modern form. The immunity rules for the unicameral parliament read as follows:

Article 36 - The representatives of the people are inviolable. - They may not be investigated, accused, nor tried, at any time, for the opinions they have expressed in the National Assembly.

Article 37 - They may not be arrested in criminal matters, except flagrante delicto, nor prosecuted unless the Assembly has permitted the prosecution. - In case of an arrest flagrante delicto, this shall be reported to the Assembly immediately, which will authorise or refuse the continuation of the prosecution. This provision also applies to the case in which a detained citizen is nominated as a representative.

In essence, these constitutional provisions comprise most of the elements which we also find in the immunity regime currently applicable in the Fifth Republic. Several observations can be made, however, which are specifically characteristic of the system of the Second Republic. First, it appears from the wording of Article 36 that the term inviolabilité had not yet undergone a process of disambiguation during the time between the revolution of 1789 and that of 1848. Article 36 declared the members of the assembly 'inviolable' and attaches to that term the definition which, according to our modern understanding, pertains to non-accountability. Another possible reading is that both elements of immunity, defined in Articles 36 and 37, are subsumed under the heading of 'inviolability'. In light of the considerations presented in section 2.4 above, it is likely that the latter reading is more accurate.

Second, neither of the two articles limits the temporal scope of immunity, as did the constitutional Charters of 1814 and 1830, where members of the Chamber of Deputies enjoyed immunity only while the chamber was in session and in the weeks immediately preceding and following it. This lack of a limitation of the temporal scope of immunity is explicable, given that the constitution provides for a session which is in principle permanent, while granting the assembly the right to adjourn its session. ${ }^{104}$

Finally, Article 37 provided that the authorisation requirement it stipulated also applied where a detainee is elected a representative. It is questionable whether this should be interpreted to mean that the assembly could free an elected member serving a prison sentence to which he had been sentenced by a court. This is unlikely, because the article only allows the assembly to refuse the authorisation of (the continuation of) the 'poursuite', the prosecution. In case of a definite criminal promulgate laws. Instead, Art. 59 provided that promulgation may be done by the president of the National Assembly in case the president fails to promulgate within the prescribed period of time. 
sentence already issued by a court, the prosecution would already have come to an end, which renders the object of the authorisation, or the refusal to authorise, moot. However, at any stage of proceedings short of an actual sentence, the assembly was able to secure the release of both a sitting member (for example, in case of an arrest flagrante delicto) and a newly elected member.

\subsubsection{The Constitutional Laws of 1875}

In 1852, the Second Republic had already turned into a de facto dictatorship, and later into the Second Empire. On 14 January, the President of the Republic, Louis Napoleon Bonaparte, announced his plans to return to the institutional structure of the First Empire. After all, the Empire under Louis Napoleon's famous uncle had proven its worth for the nation and it had 'taken the whole of Europe allied against us to abolish it'. A new constitution was promulgated on the same day, by which 'the government of the republic of France [was] conferred for ten years on Prince Louis Napoleon Bonaparte, the current President of the Republic' ${ }^{105}$ Later in the same year, the republican façade was finally abandoned with the Sénatus-Consulte of 7 November 1852, which re-established the Empire after the Napoleonic model and vested imperial power in Louis Napoleon Bonaparte and his heirs.

The imperial Constitution of 1852 was the only post-revolutionary French constitution which did not contain any immunity provisions, even though, to a large extent, its text drew on the model of the Constitution of year VIII. Parliamentary immunity also remained entirely absent from the Second Empire throughout all subsequent amendments (by Sénatus-Consulte) of its constitution.

The Second Empire ended in the defeat of France in the Franco-Prussian war of 1870-71. A provisional republican government was installed, which negotiated the peace with the newly established German empire. With the election of a new constituent assembly on 8 February 1871 and the tumultuous socialist episode of the commune de Paris in between March and May of that year, it took four more years before the institutional setting of the new republic was formalised in a constitution.

This constitution did not take the form of a single document but consisted of three individual documents: the constitutional laws of 24 February, 10625 February, ${ }^{107}$ and 16 July $1875 .{ }^{108}$ These constitutional documents stipulated that the Third Republic should have a bicameral parliament, consisting of a Senate and a Chamber of Deputies. The Senate was composed of 300 members, of whom 225 were elected by the Departments and the colonies and the remainder by the (constituent) National Assembly. The Chamber of Deputies was elected by universal (male) suffrage; the number of its members varied over time, as it was not fixed in constitutional law but left to statute. The joint session of both chambers constituted the National Assembly (to be distinguished from the constituent assembly which was dissolved after the entry into force of the new constitutional

Constitution of 14 January 1852, Art. 2.

Loi constitutionnelle du 24 février 1875, relative à l'organisation du Sénat.

Loi constitutionnelle du 25 février 1875, relative à l'organisation des pouvoirs publics. Loi constitutionnelle du 25 février 1875 sur les rapports des pouvoirs publics. 
documents), which elected the president of the republic. He, as well as the members of either chamber of parliament, had the right of legislative initiative; statutes were promulgated by the president, who also appointed the ministers. Those, in turn, were politically accountable both collectively and individually to both chambers of parliament.

It was this institutional setting with which France finally broke the cycle of constitutional volatility and instability: '[la constitution] met également fin à un rythme de production constitutionnelle et de succession politique relativement soutenu, au plan quantitatif comme au plan qualitatif, pour s'ouvrir sur une ère de stabilité' ${ }^{109}$ Indeed, in terms of longevity the Third Republic is the most successful post-revolutionary French state to date. It lasted 70 years until 1940, when it was ended by the German invasion and not by a revolution or coup.

The immunity regime laid down in Articles 13 and 14 of the loi constitutionnelle of 16 July 1875 is already very similar to the one which applies today and was, in essence, maintained both in the Fourth and in the Fifth Republic, where the scope of inviolability was only reduced by a constitutional amendment in 1995 (see part IV). Other than this recent amendment, no significant changes have been made to French parliamentary immunity since 1875. The provisions laying down nonaccountability and inviolability for the Third Republic read as follows:

\begin{abstract}
Article 13 - No member of either Chamber may be prosecuted or investigated on the basis of the opinions he expressed or the votes he cast in the exercise of his functions.

Article 14 - No member of either Chamber may, for the duration of the session, be prosecuted or arrested in criminal or correctional matters without the authorisation of the Chamber of which he is a member, except flagrante delicto. The detention or prosecution of a member of either Chamber is suspended during the session, and for its entire duration, if the Chamber so requests.
\end{abstract}

While these articles do not mention the words inviolability (inviolabilite) and nonaccountability (irresponsabilite) explicitly, they do formalise the immunity regime in its well-known two-tier structure, clearly separating the two elements and formulating them in an exhaustive way (id est, stating both the material and temporal scope of both elements of immunity in a clear manner). There is no longer any difference between the immunity regime which accrues to members of the Senate and that enjoyed by members of the Chamber of Deputies. In effect, nonaccountability for opinions uttered and votes cast in the exercise of the mandate is absolute for members of both chambers; during the session, both the criminal prosecution and the arrest of a member of either chamber are prohibited where they are not either authorised by the chamber concerned or where they happen flagrante delicto. ${ }^{110}$ In all cases, either chamber has a discretionary right to suspend the

109 Martin \& Cabanis 2000, p. 45.

110 It should be noted that the parliamentary session, during which members enjoyed inviolability, was markedly short during the Third Republic. The first article of the constitutional law of 16 July 1875 (sur les rapports des pouvoirs publics) only stipulates that the session should last for a minimum of five months, while the president had the power to 
detention or prosecution of one of its members. Such a suspension is, however, limited to the duration of the session. As a consequence, inviolability is a nonabsolute form of immunity, limited by the discretionary power of the respective chamber (which means that it cannot, other than non-accountability, be described a right of the member), and is contained by the limited duration of the parliamentary session.

\subsubsection{The Vichy Regime}

The Third Republic - or in any event the effectiveness of its constitution - ended with the adoption of the loi constitutionnelle of 10 July 1940, by which the National Assembly (the Chamber of Deputies and the Senate in joint session) ceded all constitutional power to Marshal Petain. The only article of this act reads as follows:

The National Assembly gives full powers to the government of the Republic, under the authority and signature of Marshall Pétain, to promulgate by one or several acts a new constitution for the French state. This constitution shall guarantee the rights of work, of the family, and of the homeland.

It shall be ratified by the National and applied by the Assemblies which it will have created. [...].111

By virtue of this constitutional act, Petain was at liberty to assume dictatorial powers. He did so on the very next day by decreeing three constitutional acts ${ }^{112}$ which deposed the president of the republic, transferred all legislative and executive powers of the state to Petain himself, adjourned both chambers of parliament indefinitely ${ }^{113}$ and abolished all provisions of the constitutional

adjourn both chambers twice for one month per session (Art. 2). These short sessions meant that parliamentarians of the Third Republic were only inviolable for a relatively short time per year, since inviolability was limited to the time of the session. Today, the French parliamentary session lasts 9 months.

111 The French original:

'L'Assemblée Nationale donne tout pouvoir au gouvernement de la République, sous l'autorité et la signature du maréchal Pétain, à l'effet de promulguer par un ou plusieurs actes une nouvelle constitution de l'État français. Cette constitution devra garantir les droits du travail, de la famille et de la patrie.

Elle sera ratifiée par la Nation et appliquée par les Assemblées qu'elle aura créées [...]'.

The reference to travail, famille, patrie was meant to replace the famous French motto of liberté, égalité, franternité. In his article 'Politique sociale de l'avenir' (Revue des Deux Mondes, 15 September 1940), Pétain justified the new motto as follows:

'When our young people enter their lives [...] we shall tell them that it is nice to be free, but that real liberty cannot be had except under the shelter of an absolute authority [...]. We shall tell them that equality is a good thing [...], but that [...] [equality] must be encased in a rational hierarchy, based on the diversity of functions and merits and committed [...] to the public good. We shall tell them that fraternity is a great ideal, but that [...] real fraternity can only exist within natural groups, the family, the city, the fatherland'.

112 Actes constitutionnels nos. 1, 2 and 3 of 11 July 1940.

113 The second constitutional act of 11 July 1940 provides that the chambers could only be reconvened by order of Petain. 
documents of the Third Republic which were inconsistent with these measures. Since parliament, consequently, was all but abolished in Vichy France for the remainder of World War II, parliamentary immunity was ineffective during this time, although Articles 13 and 14 of the constitutional law of 16 July 1875 were technically still in force. Article 13, providing for non-accountability for parliamentary speech and vote, was rendered irrelevant by the inactivity of parliament. Inviolability ex Article 14 was inapplicable as it only applied during the session, which was continuously suspended.

\subsubsection{The Constitution of 1946}

It has been alleged that the main difference between the Third and the Fourth Republic is to be found in their numbering. ${ }^{114}$ While this is of course a stark exaggeration, a comparative reading of the Constitution of 1946 and the constitutional laws of 1875 reveals that the differences between the two systems were indeed limited and in some cases only consisted of a difference in names.

After a first draft constitution, devised by a constituent National Assembly elected in October 1945, had been dismissed by the people in a referendum on 5 May 1946,115 a newly elected constituent assembly drafted a new constitution, which was adopted by referendum on 13 October 1946 and entered into force on the 27th of the same month. It provided for a bicameral parliament, consisting of a National Assembly and a Council of the Republic (corresponding to the Chamber of Deputies and the Senate of the Third Republic), the former elected by direct universal suffrage under proportional representation, the latter indirectly. ${ }^{116}$ Both chambers jointly elected the president of the republic, ${ }^{117}$ who appointed the ministers. The latter were accountable only to the National Assembly. ${ }^{118}$ Interestingly, the Council did not have anything but a limited suspensive veto right in the legislative procedure, ${ }^{119}$ which reinforced the dominance of the Assembly. The political functioning of the Fourth Republic was deeply troubled by the instability and volatility of government under its parliamentary system: a government only lasted six months on average. ${ }^{120}$

As was the case in the constitutional laws of 1875 , the regime of parliamentary immunity laid down in the constitution of the Fourth Republic reflects the strong position of the legislature in the system.

$114 \quad$ Duverger 1991, p. 91.

115 For the historical backgrounds of the negative result of the referendum, see Martin \& Cabanis 2000, p. 59 et seq. and Duverger 1991, p. 92-93. It is noteworthy that this was the first referendum in French history which the people answered in the negative.

116 Constitution of 1946, Art. 6. In an amendment of 1954, the conseil was renamed into sénat.

$117 \quad$ Ibid., Art. 29.

$118 \quad$ Arts. 49 and 50.

119 Art. 20

$120 \quad$ Duverger 1991, p. 99. 
Article 21 - No member of parliament may be prosecuted, investigated, arrested, detained or tried on the basis of the opinions expressed votes cast by him in the exercise of his functions.

Article 22 - No member of either Chamber may, for the duration of his mandate, be prosecuted or arrested in criminal or correctional matters without the authorisation of the Chamber of which he is a member, except flagrante delicto. The detention or prosecution of a member of either Chamber is suspended if the Chamber so requests.

The text of the immunity provisions of Articles 21 and 22 does not differ significantly from that of the previous constitution, except for a broader temporal scope of inviolability. Whereas Article 14 of the loi constitutionnelle of 16 July 1875 had merely declared members of parliament inviolable during the parliamentary session, Article 22 of the Constitution of 27 October 1946 provided for inviolability for the entire duration of the mandate. The arrest or prosecution of a member of either chamber, except flagrante delicto, was now also subject to an authorisation requirement. The constitutional amendment of 30 November 1954 brought a further modification of the inviolability provision. It re-introduced the differentiation between the period of the parliamentary session and the remaining time by creating a discretionary power for the bureau of either chamber, instead of the chambers themselves, to authorise the prosecution or arrest of a member outside the session. Further, it provided that an arrested member be freed automatically if his chamber failed to decide on the lifting of his inviolability within 30 days after the opening of the session:

Article 22 - No member of either Chamber may, for the duration of the session, be prosecuted or arrested in criminal or correctional matters without the authorisation of the Chamber of which he is a member, except flagrante delicto. Any parliamentarian arrested outside the parliamentary session may vote by delegation as long as the Chamber of which he is a member has not decided on the lifting of his parliamentary immunity. If it has not decided within thirty days following the opening of the session, the arrested parliamentarian shall be freed by operation of the law. Except in cases of arrest flagrante delicto, authorised prosecution or a final judicial sentence, no parliamentarian may, outside the session, be arrested without the authorisation of the bureau of the Chamber of which he is a member. The detention or prosecution of a member of parliament is suspended if the Chamber of which he is a member so requests.

First, the amendment of 1954 re-introduced the differentiation between the period of the parliamentary session and the remaining time. For the time when parliament was not in session, it was now for the bureau of the respective chamber to take the discretionary decision to authorise the arrest or prosecution of a member. In addition, the amended text of Article 22 now also provided for a right of an arrested member to be released if the chamber concerned failed to pronounce itself on the authorisation of his prosecution within 30 days of the beginning of the session.

This was to be the state of affairs, with regard to parliamentary immunity, for approximately four years. Then, in 1958, the Fourth Republic came to an end, and the Constitution of 1958 introduced the immunity regime which still applies today, though with a reduced material scope of inviolability after the constitutional amendment of 1995. 
Parliamentary Immunity in France

\subsection{The History of Parliamentary Immunity in France: A Summary Picture}

From the above description and discussion of the emergence of the French regime of parliamentary immunity, the circumstances under which it came into being and the subsequent development it underwent in the long succession of constitution systems during the 'waltz of constitutions' of the $19^{\text {th }}$ century, a number of conclusions should be drawn at this point. This shall help to understand the theoretical foundations of immunity and the current system to be discussed in the following parts of this chapter.

In France, parliamentary immunity cannot be said to have 'evolved' in the proper sense of the word. It is not the result of a gradual process of crystallisation from ancient legal institutions, as we have observed in the case of the United Kingdom. Instead, it has been established in the course of a most incisive and radical revolutionary process, which ended the monarchical concept of sovereignty and of popular representation under an imperative mandate, and was replaced by national sovereignty and legislative independence. The National Assembly had become the representation and, for the purpose of national will-formation, (see part III) the personification of the abstract sovereign nation and could thus claim inviolabilité, 121 which before had pertained to the sovereign monarch himself. At the same time, the Revolution should be understood not as a more or less inanimate process of change, but as a time of distressing volatility, political instability, uncertainty and threat, which the members of the National Assembly sought to alleviate by declaring themselves inviolable. Depending on which perspective one chooses in an examination of the very first immunity provisions of 1789 and 1790, they can either be seen as concomitant to the process of revolutionary change, borne out of acute fear of reprisals, or as a necessary consequence of the change of systems.

The exact legal meaning of the first immunity provisions is not certain. The wording of the National Assembly's decrees of 23 June 1789 and 26 June 1790, and the early instances of their application leave little doubt that the drafters of the decrees did not understand the term inviolabilité as excluding non-accountability. Whether they used it synonymously with non-accountability, or whether they understood it as encompassing both elements of immunity present in our modern categorisation cannot be determined conclusively. However, various historical leads indicate that the latter was the case.

Ensuing from the first immunity provisions, a two-tier system has developed which has as its primary elements, (a) absolute non-accountability of members of the legislature for utterances done in the exercise of their mandate, and (b) freedom from arrest except flagrante delicto and freedom from prosecution. The latter two are usually limited to the time of the parliamentary session and subject to a discretionary right of the chamber concerned to authorise the arrest or prosecution.

121 Note, however, that the process of terminological disambiguation between inviolabilité and irresponsabilité had not yet taken place at the time of the first National Assembly. 
Not all constitutions between the Revolution of 1789 and today provided for both of these elements; where they did, details differed considerably. However, none of the constitutions (except for the rare case of a constitution from which immunity was entirely absent, most notably the constitution of the Second Empire) $)^{122}$ departed significantly or inexplicably from the idea of the immunity system as it was conceived during the Revolution. That is to say, none added entirely new concepts to the legal organisation of immunity. Especially when contrasted to the tremendous volatility of other parts of the constitutional system, such as the form of government, immunity has thus been a remarkably stable part of constitutional law since the Revolution and has become a fixed part of what may be called French constitutional culture.

\section{Theoretical Foundations of Parliamentary Immunity}

\subsection{The Significance of Constitutional Theory}

An examination of the theoretical foundations of parliamentary immunity in France serves a double purpose. First, it is necessary to conduct such an examination in order to understand the underlying logic of the French immunity system. In order to compare this system to those of other countries, as is the aim of this study, we need to establish the relationship between the positive law of immunity and other elements of the constitutional edifice of a state. This can only be achieved by showing the links and cause-effect constructions which theory uses to support the grand structure of the state. On the other hand, theory necessarily contains elements of factitiousness. Only rarely is the complex structure of a state built entirely in pursuance of a theoretical blueprint; more often, doctrine follows the development of a state by seeking to explain and justify a posteriori the shape and form of certain elements of the grand structure. Therefore, a critical assessment of the justification provided by constitutional theory is necessary for a meaningful appraisal of the positive law.

The following will show that this is particularly true with regard to the French system of parliamentary immunity. In part II it was already observed that the emergence of parliamentary immunity in France can in principle be understood in two profoundly different ways. First, through the lens of what we called historic realism, the adoption of immunity was essentially circumstantial. From this perspective, decreeing themselves 'inviolable' was an attempt by the members of the revolutionary National Assembly to protect themselves against reprisals which they had good reason to fear, the guards already lining up outside the convention hall. In other words, non-accountability and inviolability were not conceived as a logical consequence of the new order of state. Instead they were, at first, nothing but the circumstantial by-products of a time in which the members of the National

122 Whether this was the only constitution without immunity provisions depends on the definition one chooses to apply to the term 'constitution'. 
Assembly led a rather dangerous life and the new form of government had yet to be established.

From a more detached theoretical perspective, immunity was the necessary result of the assumption, held by the first National Assembly and later written into the constitution of 1791, that the members of the legislature held a representative mandate: that they, constituting the assembly, represented the sovereign nation. ${ }^{123}$ In this sense, French doctrine describes immunity as a necessary tool to guarantee the complete liberty which is necessary to properly represent the people (see section two below).

It has already been found that these two interpretations of the emergence of immunity are not necessarily mutually exclusive. In a comprehensive study of parliamentary immunities, both perspectives on the emergence of nonaccountability and inviolability are worth exploring in their own right. Nevertheless, it may be worthwhile to distinguish the different purposes which these two perspectives serve in such an analysis. An account of the historical events which led to the adoption of immunity is useful, as it explains how and why, from a practical point of view, the immunity provisions were originally formulated, and why they developed over time in the way they did. Without such information, a comparative study could be no more than a snapshot of the current situation. An analysis of theory, on the other hand, can show how parliamentary immunity is embedded in the overarching constitutional system. Theory also provides the framework of reference for assessing the justification of immunity. While the political context of the immunity system of the Third, Fourth and Fifth Republic is hardly comparable to that of the Revolution, its doctrinal base has remained remarkably - or perhaps suspiciously - stable.

Guérin-Bargues recognises that the reason for this doctrinal stability is mainly to be found in the tremendous influence of the work of Raymond Carré de Malberg. ${ }^{124}$ She argues that his positivist theory of law and state lies at the basis of several doctrinal works on parliamentary immunity throughout the $20^{\text {th }}$ and early $21^{\text {st }}$ century. ${ }^{125}$ No other author has seriously challenged the theoretical justification of parliamentary immunity through Carré de Malberg's theory of state. In the following, we will try to trace the lines of argumentation of both this classical justification of parliamentary immunity, and the criticism offered by GuérinBargues.

It should be noted - but ignored for practical reasons, since the term is commonly used in this way - that the phrase 'representative mandate' is a contradiction in terms. This is at least the case when defining 'representation' as it is done in French constitutional doctrine. The term 'mandate' (latin mandatum) originally means 'commission' or 'order' (Cf. Lewis \& Short, A Latin Dictionary). Thus, being someone's mandatary means to act for that person upon his instructions or order, whereas a representative acts independently in lieu of the represented. For the same reason the term 'imperative mandate' is tautological.

$124 \quad$ 1861-1935.

125 Guérin-Bargues 2011, p. 103 et seq. In particular, she refers to Marchand 1950; Soulier 1966; Bonnotte 2002. In the relatively scarce body of legal literature on the subject of parliamentary immunity, these works stand out as the most exhaustive contributions. 


\subsection{The Justification of Parliamentary Immunity in Classical Theory after Carré de Malberg}

The tremendous constitutional volatility of the $19^{\text {th }}$ century has led to the emergence and demise of a variety of forms of government during the 'waltz of constitutions', outlined earlier in this chapter. However, a major part of French constitutional theory still draws on the earliest developments of the Revolution of 1789 and not, crucially, on doctrinal elements and constitutional texts which were introduced at a later stage. The doctrinal justification of parliamentary immunity as a condition for the representative mandate relies on the conception of national sovereignty as believed by Raymond Carré de Malberg and several others. Their theories, in turn, were based on the revolutionary thinking from which Siyès had derived the notion of representative and democratic government as opposing concepts.

The continued validity of the idea of national sovereignty as proposed by Carré de Malberg as the basis of immunity is not entirely self-evident, though almost globally accepted in the literature. At the time that Carré de Malberg wrote, during the Third Republic, the concept of national sovereignty was no longer inscribed in the text of the constitution. Nor had it been in several previous constitutions since the Revolution (see section 2.3 above). Nevertheless, he argued:

'Et si, aujourd'hui, on ne trouve aucune formule spéciale, à ce sujet, dans la Constitution si laconique de 1875, les auteurs n'en sont pas moins d'accord pour dire que toute l'organisation constitutionnelle actuellement existante est basée sur l'idée de souveraineté nationale' ${ }^{126}$

In his view, the concept of national sovereignty was thus still supported by doctrine, even though it was no longer part of the positive constitution itself. Carré de Malberg attributes this to the constitution being 'laconic'. Accordingly, it was the silence of the constitutional laws of 1875 on the matter of sovereignty which allowed him to build his doctrine on earlier constitutions and, for the most part, on doctrine alone. However, when we look at the now much longer timeline of constitutional development with hindsight, we can observe that, after the first revolutionary constitution, national sovereignty has never again been unreservedly endorsed in constitutional texts. While this does not automatically allow any conclusions as to the validity of the concept, we must at least question its unconditional position at the foundation of substantial parts of French constitutional law - most notably parliamentary immunity.

\subsubsection{National Sovereignty and Representation}

The link between the concept of national sovereignty and parliamentary immunity is the mode of representation. Applied to the legislative branch of government, this 
is translated into the nature of the parliamentary mandate. ${ }^{127}$ In order to understand if and how the mandate justifies or in fact necessitates immunity, one must first see how, in constitutional theory, the nature of the mandate (id est, representative or imperative) is conditional on the concept and form of sovereignty. A considerable body of literature has dealt with this question. ${ }^{128}$

One of the cornerstones of classical French constitutional theory ${ }^{129}$ is the assumption that representative government is a necessary consequence of national sovereignty. Although to a certain degree blended into one in the text of the present-day constitution, it is necessary to distinguish the two concepts of national and popular sovereignty. This is for the purpose of understanding exactly why representative government should follow from national sovereignty, and what is meant, in this context, by the term 'representation' as opposed to 'delegation'. Traditional doctrine presents this thought in the following way.

In order to distinguish 'people' from 'nation' - and thus popular from national sovereignty - it helps to attach to the term 'nation' a set of abstract qualities which are lacking in the 'people': 'la nation forme une entité, personne morale, distincte de ceux qui la composent ou qui la constituent. La nation serait faite des vivants et des morts et de ceux à naître'. ${ }^{130}$ Thus, the nation is an entirely abstract being, which is distinct from its component parts. Those comprise not only the contemporary nationals, but also the dead and those yet to be born. This signifies that the nation is a timeless, entirely abstract concept and its abstract nature is a defining part of its existence. The term 'people', on the other hand, merely means those who currently live, taken as a collective of individual beings physically present in the world.

Because the nation exists, both materially and temporally, in the abstract, it is indivisible, inalienable and imprescriptible. ${ }^{131}$ This means that it cannot be said to 'belong' partly to each of its components (in particular not to individual citizens or to the people as a whole), that 'nationhood' cannot be transferred or limited to some of them while excluding others, and that it cannot cease to exist. Since these characteristics apply to the nation, they also apply to the primary property of the nation, sovereignty. ${ }^{132}$ Carré de Malberg defines sovereignty as supreme power, with no force above it and none coequal with it:

'La souveraineté, c'est le caractère suprême d'un pouvoir: suprême, en ce que ce pouvoir n'en admet aucun autre ni au-dessus de lui, ni en concurrence avec lui'.133

The executive also exercises sovereign power. For the purposes of this study, however, it need not be considered separately.

An influential part of this body of literature is still the work of Carré de Malberg 1920-22. For a more specific and much more recent discussion of the theory of sovereignty and representation, see Brunet 2004.

Brunet 2004, p. 31.

Brunet 2004, p. 30.

Ibid.

This is the refutation of the idea of Rousseau that every citizen is part-sovereign, the thought which lies at the basis of popular sovereignty.

Carré de Malberg 1920-1922, Vol. 1, p. 70. 
The link between representative government and national sovereignty can be found in the problem that the nation, abstract entity that it is, is unable to form and manifest a will. On the one hand, national will-formation cannot take place in those of its component parts which are physically present (the living citizens who constitute the people), since this would conflict with the indivisibility of sovereignty and since it would violate the principle that the nation is essentially distinct from its parts:

'La souveraineté [...] est dite nationale, en ce sens qu'elle réside indivisiblement dans la nation tout entière, et non point divisément dans la personne, ni davantage dans aucun groupe, de nationaux. La nation est donc souveraine, en tant que collectivité unifiée, c'est-à-dire en tant qu'entité collective, qui, par là même qu'elle est le sujet de la puissance et des droits étatiques, doit être reconnue comme une personne juridique, ayant une individualité et un pouvoir à la fois supérieurs et indépendants d'eux' ${ }^{134}$

Accordingly, sovereignty is vested in an entirely abstract entity, which, however, must be understood as having individual legal personality. This construction, on the other hand, bears one readily apparent problem: while the nation is assumed to have individual legal personality, the abstract entity evidently does not have at its disposal a physical mind of its own in which any process of national will-formation could take place, nor any possibility to manifest its will. Classical doctrine derives from this the conclusion that, in order to exercise sovereignty, the nation must be represented. ${ }^{135}$ However, as already mentioned, representation cannot mean that sovereign powers are for practical purposes simply transferred to the not-soabstract part of the nation, to the people. This would be at odds with the nature of the nation, and, according to a classical definition, it would not amount to proper representation.

When considering the latter thought, it must be borne in mind that representation is essentially different from mere delegation. In classical French constitutional theory, the representative is distinguished from the delegate by his characteristic independence and autonomy. ${ }^{136}$ The delegate does not represent the sovereign, as 'he has [...] no decision-making power of his own, all his acts are determined in advance by legal rules or by binding instructions, or he may not decide anything without the ratification of the sovereign' ${ }^{137}$ The true representative, however, decides autonomously in lieu of the sovereign and must therefore be capable of true independent will formation. ${ }^{138}$ It must therefore be concluded, in the words of Christophe Bonnotte, that what is transferred from the sovereign nation to her representatives is not the ownership or enjoyment of sovereignty ('sa propriété ou sa jouissance'), but merely its exercise. The representatives are thereby made 'titulaires effectifs' of this supreme power. ${ }^{139}$ In short, the bearer of a truly

Carré de Malberg 1920-1922, Vol. 2, p. 173.

Brunet 2004, p. 30.

Bonnotte 2002, p. 74

Esmein 1927, p. 441.

Bonnotte 2002, p. 74

Bonnotte 2002, p. 73. 
representative mandate exercises sovereignty autonomously, while not being sovereign himself. In a seemingly paradoxical twist, it is thus precisely the severance of every link between the representative and the represented nation which enables true representation.

If these thoughts are translated from mere theory into an actual constitutional system, this leads to the notion that national sovereignty requires a representative legislative mandate in which the representatives are not accountable. They are certainly not accountable to the people, and in principle not to anyone, since the only entity to which account would theoretically be due - the nation - is incapable of holding them to account. Consequently, national sovereignty is incompatible with delegation, that is, with an imperative legislative mandate as it was enjoyed by the members of the états généraux prior to the Revolution.

The opposite situation materialises under popular sovereignty. The 'people' is not abstract, it is the very physical community of all individual living citizens. Because popular sovereignty therefore rests with a group of actual persons, it can and must be partitioned between those: every citizen is part-sovereign and this sovereignty is thus 'atomised' ${ }^{140}$ Apart from being split, however, the properties of sovereignty must remain essentially the same. Popular sovereignty cannot be exercised through representation because the part-sovereign citizens who are in a position to exercise their share of power would alienate sovereignty (which means, would be no longer sovereign) if they were to be represented. However, it would be practically impossible for every citizen to opine on every issue for the purpose of national will formation, so popular sovereignty allows for delegation. ${ }^{141}$ This means that certain individuals are assigned to conduct the will formation process. However, this would have to be understood as an imperative mandate. Delegates equipped with such a mandate do not exercise sovereign decision making powers autonomously but are bound by instructions they receive from their principals - the electors - to whom they would also remain accountable.

From a juxtaposition of national and popular sovereignty and the consequences ensuing from either, classical French constitutional doctrine infers that the two types of sovereignty and the two types of mandate stand in complete opposition to each other. This means that neither concept of sovereignty could sustain the type of mandate which ensues from the other.

It is important to note, at this point, that representation as defined in classical theory is not synonymous with (representative) democracy; in a strictly formal sense the assumption of national sovereignty even precludes it. ${ }^{142}$ In the view of Carré de

Brunet 2004, p. 31.

Ibid.

As a formal notion, democracy is synonymous with popular sovereignty. Along with this rather obvious conflict between national sovereignty and democracy, the definition of representation in classical French theory also makes representative democracy formally incompatible with national sovereignty: Kelsen argues that '[a]ccording to the traditional definition, a government is 'representative' because and insofar as its officials during their tenure of power reflect the will of the electorate and are responsible to the electorate'; General Theory of Law and State, Cambridge (Ma.): Harvard University Press, 1945, p. 289. In French 
Malberg, the concept of representation as a necessary consequence of national sovereignty does neither automatically entail nor favour any of the classical forms of government of monarchy, democracy or aristocracy. ${ }^{143}$ Instead, he argues that representative government - regardless of which organ, entity or collective represents the sovereign - should be added to that list as a new form of government. ${ }^{144}$ For there is an essential difference, in the light of the logic of representation, between a sovereign monarch as he existed in absolutism and one that, together with the National Assembly, merely exercises sovereignty as a representative in lieu of the sovereign nation. This was envisaged by the French constitution of 1791 . The difference is that, in the latter situation, sovereignty precedes and justifies royal power, but is by no means identical with it. Under the Constitution of 1791 the form of government was therefore neither true monarchy nor true democracy, since neither king nor people were considered sovereign. ${ }^{145}$ Instead, national sovereignty had led to a new form of government - representation.

What, if any, are the practical implications of the above? Is there more to national sovereignty and the ensuing theory of representation than an intellectual exercise in 'legal metaphysics'? It has been argued that the attribution of sovereignty to an entirely abstract entity was meant to prevent that any actual entity or organ would assume sovereignty. For de Soto, this is the quintessential function of the idea of national sovereignty. Where the highest power is ascribed to an entirely abstract - and thus harmless - nation, we can evade the dangers of one omnipotent institution:

\footnotetext{
'La vérité c'est qu'en déclarant la Nation « omnipotente », on a voulu supprimer toute souveraineté véritable [...]. Le peuple omnipotent, chez Rousseau, ne fournit plus ici que des électeurs et il n'y a pas plus de corps électoral souverain qu'il n'y a pas de Parlement souverain ou de chef d'Etat ou de Constituant souverain : il y a seulement des électeurs, des députés, un exécutif, des constituants, représentants de la Nation souveraine. ${ }^{146}$
}

It will easily be admitted that both the concept of national sovereignty and that of representation in the strict sense are constitutional fictions - virtual constructions which are imposed on a factual situation in order to explain or legitimise it, or, in this case, to withhold legitimacy from any one organ that might claim it. ${ }^{147}$ In this light, the historical importance of the theory of national sovereignty and representation lies in the fact that it provided legitimacy to the revolutionary

classical theory, however, a mandate with these characteristics precisely is not representative but imperative and as such is irreconcilable with national sovereignty.

143 Carré de Malberg 1920-1922, Vol. 2, p. 181.

144 Carré de Malberg 1920-1922, Vol. 2, p. 180.

145 Carré de Malberg 1920-1922, Vol. 2, p. 184.

146 de Soto et al. 1946, p. 82-83.

147 A comparable and related constitutional fiction is that of the people's authorship of a constitution, a virtual tool to bridge the gap between the factual constitutional legislator and the legitimate pouvoir constituant. Cf. Riberi 2007. 
transformations of the French state in which now none of the institutional actors could claim supreme power.

At the same time, and perhaps even more importantly, the concept of national sovereignty and representation provided the self-proclaimed representatives of the sovereign nation with virtually unlimited constituent freedom, both vis-à-vis the monarch and vis-à-vis the people. Carré de Malberg confirms this in his conclusion:

‘[C]e que la Révolution française a fondé en vertu du principe de la souverainté [sic] nationale, c'est le régime représentatif, un régime dans lequel la souveraineté, étant réservé exclusivement à l'être collectif et abstrait nation, ne peut être exercée par qui que ce soit qu'à titre de représentation national. Telle est, en dernière analyse, la signification de la souveraineté nationale'.

One cannot but admire the elegance of this construction: While nobody can claim to possess sovereignty, the representatives can claim to be the ones entitled to exercise it. At the same time no-one is empowered to hold them to account.

If we accept this conclusion we can thus observe that, historically, the primary function of the theory of national sovereignty and the system of representation was to justify the self-conception of the revolutionary representatives of the nation and the system of government which they were about to create. In light of the historical events of the Revolution and the novelty - or, one could say, the experimental nature - of the post-revolutionary system at its time, the development of this theoretical superstructure is not surprising, as it de-legitimised the ancien régime and simultaneously provided legitimacy to virtually any new form of government to be chosen in its place. Hence, the constitutional fiction that is national sovereignty was by no means an intellectual exercise devoid of any practical purpose or use, since it was taken to legitimise the most incisive factual measures.

Positive (constitutional) law has drawn on this fiction. The results of that are still visible today, as doctrine still assumes that national sovereignty and representation constitute the foundation of immunities of holders of high offices of state and of members of the legislature. The following is to show how the representative mandate is assumed to necessitate the two elements of nonaccountability and inviolability.

\subsubsection{Parliamentary Immunity as a Corollary of the Representative Mandate}

We have seen that, whereas the holder of an imperative mandate is an agent bound by the instructions of his principal, a true representative decides freely in lieu of the sovereign. According to Bonnotte, building on the reasoning of Carré de Malberg, Esmein and others, the will expressed by those endowed with public power must therefore not be considered the proper will of these individuals themselves; rather, it is an expression of the national will. ${ }^{148}$ However, any difference in content between the two is by definition excluded. Carré de Malberg expresses this even more poignantly: 'l'essence de la représentation, c'est que le représentant possède les 
mêmes pouvoirs que s'il était personnellement souverain'. ${ }^{149}$ It is this assumption of complete liberty of the representative vis-à-vis the represented from which classical French theory deduces the requirement of the greatest possible independence of the representative. 150

On this note, Bonnotte observes that, for the constituent National Assembly of 1789-1791, the defining element which distinguished the true representative from a mere functionary or civil servant was the former's complete autonomy. ${ }^{151}$ The will of the representative, after all, could only properly substitute for the will of the nation - or in fact be that will - if it was completely free from any distortion or interference. Since the abstract sovereign nation is incapable of will formation other than through its representatives, it is unable to bind or limit the will expressed by them by means of instructions. The electorate (the people), on the other hand, must also not interfere with the process of will formation which takes place among the elected representatives. After all, the electors do not exercise sovereign power, their constitutional role as the physically present fraction of the nation is merely to physically provide the representatives by electing them (électorat-fonction as opposed to électorat-droit). ${ }^{152}$ Other than this constitutive act there is no link between election and representation. ${ }^{153}$

That the justification for parliamentary immunity should lie in the independence of the representative seems curious, or at least counter-intuitive, especially if one looks beyond mere theory and takes into account the very real possibility of abuse of power by a representative completely unbound by the will of the represented and unaccountable to him. This argument can be found in the work of the constitutionalist and legal historian Adhémar Esmein (1848-1913). He argues that it is precisely the complete autonomy of the representative which at first sight seems quite irreconcilable with immunity - after all, the representative wields power, though independently, not in his own right but for the nation and should, consequently, be accountable to her:

149 Carré de Malberg 1920-1922, p. 208.

150 In outcome, this thought is very reminiscent of the British doctrine of parliamentary sovereignty. The route taken to reach this conclusion, however, could not be more different.

$151 \quad$ Bonnotte 2002, p. 75.

152 The distinction between électorat-droit and électorat-fonction refers back to the concepts of national and popular sovereignty. Under national sovereignty, where 'the people' is not identified with 'the nation' and where elections are merely a function exercised by the people in order to provide representatives of the nation, there would be no need for universal suffrage, since the political will of the electorate and the reflection of that will in the legislative assembly is immaterial. Conversely, where (ideally) all citizens enjoy a right to elect the candidate they see fit according to their own political views, this is taken to be an attribute of popular sovereignty. That the current French constitution no longer adheres to the idea of the électorat-fonction becomes evident, among others, when considering the possibility of referenda, by which 'the people exercise national sovereignty', as can be read in Art. 3 of the constitution of 1958 .

Bonnotte 2002, p. 76 . 
It seems that national sovereignty has as its necessary consequence the full responsibility of all those who exercise public authority, under whichever title. All of them act, after all, not pursuant to their own right, but in name of the nation in whom sovereignty resides. This seems true not only with regard to so-called functionaries, [...] but also and above all with regard to the representatives, that is, with regard to those who hold a more or less arbitrary power of decision and who will for the nation. As the danger to see the delegate [le délégué] abuse a power which does not belong to him is greater in the second case, responsibility appears to imply two things: 1 . a sanction, each time a functionary or representative exceeds his powers; 2 . the revocability of any functionary or representative by the authority which has conferred his power or his function on him, whenever this authority may fear that he, without trespassing the limits of the powers conferred on him, exercises them [...] in a manner which is not useful or even dangerous. This is the natural condition of someone who merely exercises the right of another by the will of another. ${ }^{154}$

The reasons why these 'natural' consequences of national sovereignty and representative government - responsibility and the possibility of a recall - had to be abandoned in practice are, in Esemin's view, only of practical nature. On the one hand, he observes, they are very difficult to organise and to cast in concrete legislation while staying true to the principles of representative government. On the other hand,

[responsibility] would most often turn against the public interest, against the veritable interest of the represented, since the action of the representatives, who most often need to be free in order to be useful, would be paralysed by fear and since the continuous interplay of the representative institutions would be troubled or interrupted. ${ }^{155}$

He therefore concludes that, contrary to his initial considerations, 'one can almost say that representative government naturally tends towards non-accountability [irresponsabilité] of the representatives'. ${ }^{156}$ With regard to members of the legislature specifically, he notes that their mandate is 'the most representative one', as it is in them that the national will manifests itself. Consequently, they necessarily enjoy the widest measure of irresponsabilité. In addition, their mandate cannot be revoked, for want of an authority which could have jurisdiction to do so; after all, while the members of the legislature derive their mandate from elections, it would amount to a fundamental change in the nature of this mandate - from representative to imperative - if the power to revoke the mandate were granted to the electorate. Even if the electorate could not issue direct instructions to the representatives as they did in the états généraux before the Revolution, the power of recall would indirectly bind the representatives to the wishes of the electors.

Parliamentary immunity has generally received relatively little doctrinal attention throughout the Fourth and Fifth Republic. Still, it is clear that constitutional theory after Esmein and Carré de Malberg generally sees immunity as a necessary consequence of the representative mandate, which in turn is seen as a

Esmein 1927, p. 444-445.

Esmein 1927, p. 445.

Ibid. 
corollary of the concept of national sovereignty. Some important works ${ }^{157}$ confirm this. Pierre Marchand, in his thesis of 1950 on parliamentary immunity in the Fourth Republic, acknowledges the completely fictional nature of the concept of national sovereignty. However, he remains firm on the point of the necessity of the absolute freedom in which the parliamentarians, who may not be but do act as sovereign, must exercise their mandate in a representative system, the existence of which he does not deny. With regard to the legislator in a representative system, he writes: 'les immunités parlementaires apparaissent comme un prolongement naturel du même dessein dont elles garantissent le respect'. ${ }^{158}$ In this sense, he sees both elements of parliamentary immunity as 'natural' attributes of parliament, but not of the individual parliamentarian: 'l'irresponsabilité et l'inviolabilité parlementaires ne sont pas établies dans l'intérêt personnel de chaque député, mais dans l'intérêt du [...] Parlement tout entier quelle qu'en soit par ailleurs la nature'.159

Gérard Soulier's thesis on parliamentary immunity of 1966 is the most extensive work of the $20^{\text {th }}$ century on this subject. He is even less critical of the Malbergian fiction of national sovereignty, which he assumes as the starting point for the straight line of argumentation which we tried to outline above: national sovereignty necessitates a representative mandate, which in turn necessitates the complete liberty of the parliamentarian. The protection of this liberty is the aim of parliamentary immunity. ${ }^{160}$ In contrast with Marchand, Soulier does recognise the distinctness of the two elements of immunity, non-accountability and inviolability. However, he views them as two sides of the same coin, each in itself rather worthless without the other:

Without inviolability, non-accountability would be [...] futile. For what would it serve the deputy to be totally free in debate and in his vote if he were intimidated, constrained by the threat of prosecution or, more radically yet, prevented from debating or voting by the exercise of such prosecution? In reality, if inviolability is complementary to non-accountability, it is its necessary, indispensible complement. ${ }^{161}$

Much in the same vein, Christophe Bonnotte, in his comprehensive theoretical analysis of the notion of immunity in French constitutional law, finds that

[T] he requirement that the representatives be autonomous constitutes an almost axiomatic principle. This requirement demands for the institution of immunities insofar as they aim to make sure that the governing are not troubled by legal proceedings which are inappropriate, ill-founded or which constitute political manoeuvres: in this sense, the constitutional immunities appear to be both the guarantee and, at the same time, the condition for the independence of the representatives. ${ }^{162}$

Cf. supra at 125 .

Marchand 1950, p. 27.

Marchand 1950, p. 29.

Soulier 1966, p. 18 et seq.

Soulier 1966, p. 38.

Bonnotte 2002, p. 72-73. 
The one author who has recently pleaded for a more differentiated appraisal of nonaccountability and inviolability is Cécile Guérin-Bargues. On the basis of an extensive review of the history, doctrine and recent application of parliamentary immunity in France, she reaches the conclusion that the link between both components of the immunity system and the representative mandate, assumed by others to be a logical necessity and a constitutional 'axiom', is in reality much weaker than commonly assumed. She reasons that, since the two immunities have been adopted at different points in time and for different political and practical reasons, they should, first of all, be considered individually. ${ }^{163}$ Second, she argues that the purely abstract Malbergian concept of representation does not - and due to its paradoxical nature cannot ${ }^{164}$ - match with political reality, which however has to be taken into account in a meaningful appraisal of the justification of immunity. Third, while she still views non-accountability as a condition for the functioning of parliament under a concept of representation adjusted to constitutional reality, she contests the justification of inviolability. Whereas non-accountability aims at safeguarding the complete freedom of speech and the parliamentary vote, she claims that inviolability aims primarily at the completeness of the legislative assemblies, since it prohibits the arrest of members. ${ }^{165}$

However, it is, in her view, not necessary for the legislative assemblies to be complete in the sense that they accurately reflect the results of their elections, since it would be manifestly at odds with the concept of the representative mandate to assume that the will expressed by the legislator must conform or reflect the political will of the electorate. In this sense, Guérin-Bargues argues, the justification of inviolability as a means to ensure the completeness of parliament would be paradoxical even if we were to accept the theory of representation in the form presented by Carré de Malberg. ${ }^{166}$

The work of Guérin-Bargues' is a 'reality check' on the traditional justification of parliamentary immunity, with the outcome that the justification of, in particular, inviolability, is defective for the reasons outlined above. These reasons seem to lead to the conclusion that - since the assumption of a straightforward systemic necessity of non-accountability and inviolability turns out to be indefensible - one had better look for a justification of the immunity system in today's political and institutional reality. For Guérin-Bargues, this does not mean that the element of inviolability, namely, freedom from arrest even for crimes and misdemeanours committed in the

163 Guerin-Bargues 2011, p. 409. This is one of her central propositions, setting her approach apart from that of previous authors.

164 The paradox which she sees in the theory of national sovereignty and representation is, in short, to be found in the assumption that it is precisely the complete severance of the link between the representative and the represented has as its ultimate effect the identification, for all practical purposes, of the two with each other. Since the will formed by the representatives is the will of the sovereign nation and since no accountability mechanisms exist between the assumed sovereign (or anyone else) and its representatives, the differentiation between the two is rendered meaningless. Hence, no valid justification of the immunity system can be derived from this differentiation. Cf. Guérin-Bargues 2011, p. 108-112.

165 Guérin-Bargues 2011, p. 117 et seq.

166 Guérin-Bargues 2011, p. 123-130. 
extraprofessional sphere, should be abolished, as persisting institutional imbalances still pose the threat of politically motivated proceedings. ${ }^{167}$ We will look more closely into the latter argument in part three of the present chapter.

The argumentation presented by Guérin-Bargues suggests that the justificatory power, with regard to parliamentary immunity, of the theory of national sovereignty and representation is intrinsically weak. Furthermore, a justification on this basis is not useful if constitutional reality does not reflect the Malbergian idea of national sovereignty. A justification of the immunities which emanates from the logic of this idea can thus only be of any value if the idea itself is, at least in principle, accepted as the foundation of the system. In order to complete our discussion of the theoretical foundations of parliamentary immunity, we need to establish whether that is actually the case.

\subsubsection{Popular vs. National Sovereignty: Constitutional Text and Reality}

Both the declaration of 1789 and the Constitution of 1791 express the principle of national sovereignty. Article 1 of the latter states as follows:

'La Souveraineté est une, indivisible, inaliénable et imprescriptible. Elle appartient à la

Nation; aucune section du peuple, ni aucun individu, ne peut s'en attribuer l'exercice.

Between these early stages of the Revolution and the Constitution of 1793 (constitution de l'an I; it never entered into force), however, a certain shift has taken place, replacing national sovereignty with popular sovereignty. Article 7 of the Constitution of 1793 allocates sovereignty with the people:

Le peuple souverain est l'universalité des citoyens français.

It has been suggested that this shift can be attributed to the Montagnard group of deputies who drafted this constitution and expressed their left-leaning political views by the adoption of popular sovereignty. However, this should be considered an oversimplification. It is true that the concept of national sovereignty can, to a certain extent, be linked with more conservative political views and popular sovereignty with more progressive political ideas. However, this categorisation is not reflected by other provisions of the Constitutions of 1791 and 1793. Curiously, the Constitution of 1793 maintains the explicit prohibition of an imperative mandate, which, as we have seen, doctrine has deemed a necessary consequence of popular sovereignty. The view that the adoption of popular sovereignty was a corollary of a political swing to the left is also not confirmed by the Constitution of 1795 (constitution de l'an III, the Constitution of the Directorate), which reiterates in Article 2 the sovereignty statement of its predecessor but then maintains the prohibition of imperative mandates, does not allow referenda and furthermore provides for census suffrage - ideas which can hardly be attributed to leftist 
ideology. 168 Rather, these inconsistencies should be read as signs of a certain 'confusion'169 or, more precisely, an indication of the lack of conceptual clarity and disambiguation at the time.

While the Constitutions of year VIII (the Constitution of the Consulate) and also those of the first Empire and the restored monarchy are silent on the matter of sovereignty (the latter stipulates in Article 14 that the King is 'chef suprême de l'État'), Article 1 of the Constitution of the Second Republic reads as follows:

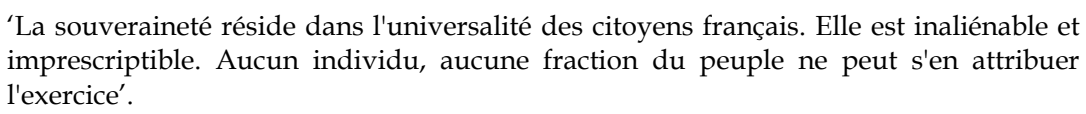

Hence, the conceptual blur which could already be observed in the Constitutions of the First Republic had not become any clearer.

The restoration of the French empire in 1852, though of course factually a coup d'état, might be seen as a test case for the question whether popular or national sovereignty was the prevailing concept in this era. This is not to say that adherence to either concept would have made a practical difference to the events of 1851 and 1852. However, the constitutional documents by which Napoleon III had his coup d'état legalised, and the procedural form in which he chose to cast the pretence of its legitimacy, reveal that the new emperor deemed popular sovereignty better suited to legitimise his usurpation of power. In the proclamation of 14 January 1852, the soon-to-be emperor refers to the 'sovereign judgment' of the people he is addressing. ${ }^{170}$ Later that year, the decree by which the empire is restored is ratified by a referendum in which the French people accept a formula by which the restoration of the empire is attributed to its will, not that of a sovereign nation: 'Le peuple veut le rétablissement de la dignité impériale dans la personne de Louis Napoléon Bonaparte [...]'. There is no evidence of national sovereignty being considered in any way in establishing the Second Empire.

The documents which form the Constitution of the Third Republic, again, do not contain an allocation of sovereignty to either the people or the nation at all. Also the texts of the Constitutions of the Fourth and Fifth Republic did not return to an 'undiluted' concept of national sovereignty. Article 3 of the Constitution of 1946 states:

'La souveraineté nationale appartient au people français. Aucune section du peuple ni aucun individu ne peut s'en attribuer l'exercice'.

The same article, in the Constitution of 1958, maintains this formula and adds that the people shall 'exercise sovereignty by its representatives and by referendum'.

Cf. Bermann \& Picard 2008, p. 6.

Pactet \& Mélin-Soucramanien 2007, p. 84-85.

'La Constitution actuelle proclame [...] que le chef que vous avez élu est responsable devant vous; qu'il a toujours le droit de faire appel à votre jugement souverain, afin que, dans les circonstances solennelles, vous puissiez lui continuer ou lui retirer votre confiance'. 
The above analysis of constitutional texts alone readily shows that national sovereignty, conceived of in the early days of the Revolution, was by no means passed down from one form of government to the next throughout the 'waltz of constitutions' without ever being disputed or altered. Instead, the modern constitutional realisation of national sovereignty - if one can still speak of the same concept - seems to attempt the levelling-out of any perceptible, practical difference between national and popular sovereignty and to install a sort of 'blended sovereignty' instead.

The wording of Article 3 of the Constitution of 1958 leaves no doubt as to who is sovereign: the people. However, the abstract concept of 'nation' is preserved in the first half-clause, which does not exactly identify the people with the nation but only declares that national sovereignty belongs to the people. If this statement, paradoxical as it appears when read against the light of classical constitutional theory, is the only remnant of national sovereignty today, can we then conclude that popular sovereignty is the concept which truly applies in the Fifth Republic? And is it the one which we should use as the benchmark for an assessment of the theoretical justification of parliamentary immunity? This would probably be a step too far; after all, the declaration of the rights of man and the citizens of 1789 whose Article 3 proclaims national sovereignty is still part of the bloc de constitutionnalite, the entirety of French constitutional norms and values. ${ }^{171}$ It is therefore assumed today that the main significance of national sovereignty, limited though it is by Article 3 of the Constitution, lies in the prohibition of the imperative mandate. Each elected deputy is still a representative of the entire nation. ${ }^{172}$ True, the introduction of universal suffrage ${ }^{173}$ and the possibility of direct democracy - most remarkably also in the constitutional amendment procedure (Article 89 of the Constitution of 1958) - have made popular sovereignty 'gain territory' over the past two hundred years, while national sovereignty seems to be on the retreat. ${ }^{174}$ Nevertheless this does not merit the conclusion that the blended concept of sovereignty inscribed in the constitutions of the Fourth and Fifth Republic does not warrant, in principle, the system of representation. Members of the Senate and the National Assembly are unbound by the will of their electors; they do not represent their constituents and cannot be recalled, other than in regular new elections. Therefore, parliamentary immunity will still have to be assessed and justified with the representative

171 The preamble of the constitution of 1958 refers, among others to the declaration of the rights of man and the citizens of 1789. In a fundamental decision of 16 July 1971 (Decision No. 71-44 DC, Liberté d'association) the Constitutional Council has recognised that the preamble, and with it the documents to which it refers, together with the current constitution, form the socalled bloc de constitutionnalité, the body of constitutional law which the Council accepts as its framework of reference.

172 Pactet \& Mélin-Soucramanien 2007, p. 85.

173 Which is, however, never truly universal, since it usually excludes minors and other categories of citizens deemed incapable to make a conscious and informed decision. In this sense, popular sovereignty, of which universal suffrage is taken to be an attribute, is of course also based on elements of constitutional fiction.

174 Pactet \& Mélin-Soucramanien 2007, p. 85. 
mandate as a framework of reference, though the stringent Malbergian logic should be applied with care and without losing sight of constitutional reality.

\subsection{Theoretical Foundations: A Summary Picture}

With regard to constitutional theory it is generally impossible to proceed in the same way as we do with theories of natural science. We cannot prove or dismiss the doctrine of national sovereignty or popular sovereignty in the sense that we could determine its 'truth' according to assumed pre-existing laws of nature against which it could be tested. Where constitutional theory introduces and defines at the very basis of a constitutional system a set of principles or 'axioms', such as those of national or popular sovereignty or also that of parliamentary sovereignty in the UK, these will always take the form of legal fictions with their own inherent logic. Whenever we work with constitutional fictions, therefore, we have to be aware of our vantage point.

In one analytical approach, we may analyse the positive law of parliamentary immunity, using as our framework of reference the systemic grid of a legal fiction like national sovereignty. Such an analysis allows us to determine whether positive law matches the legal fiction, id est whether, for instance, the rules of parliamentary immunity are reconcilable with or justified by national sovereignty and representation. Any such conclusion, however, will only be valid in the light of the inherent logic of our constitutional fiction. In another analytical approach, we can question the justificatory model created by a constitutional fiction by using the positive law and its factual development as our framework of reference.

In the foregoing, we have tried to trace both analytical approaches as they have been used by other authors in order to elucidate the relationship between the French system of parliamentary immunity and classical French constitutional theory. We have found, first, that the principle of national sovereignty was laid down as the foundation of the constitutional system during the French Revolution with the specific purpose of creating a system in which those who exercised constituent and legislative power were independent from the executive and from their electorate. In this system of representation, the will of the representatives is identified with the general will and is completely unchallengeable.

Second, national sovereignty as the basis of the constitutional system has not been preserved after the Revolution without serious concessions. Already during the Third Republic, the period in which the most influential contributors to constitutional doctrine reiterated national sovereignty and postulated the representative system as its logical consequence, the actual constitutional and institutional setup of the French state reflected a blend of elements attributed to national and popular sovereignty, with a strong trend towards the latter. Nevertheless, the representative mandate - formulated negatively as the prohibition of the imperative mandate - has remained in place despite elements of direct democracy and the électorat-droit (instead of the électorat-fonction) which are attributed to popular sovereignty. Thus, the representative legislative mandate still stands as the key concept for an analysis of parliamentary immunity. 
Considering the two-tier system of parliamentary immunity in the light of the internal logic of the system of representation, we have seen that non-accountability appears to be a natural corollary of representation. Inviolability, on the other hand, has at times been presented as the necessary 'prolongation' of non-accountability, that is, as an indispensable additional layer of protection for the representatives of the nation. However, there are strong arguments against the justification of inviolability as a necessary consequence of the representative mandate. While inviolability is of course not precluded by representation, it can be argued that this theoretical justification alone is too weak to support an immunity which reaches that far.

Consequently, the question whether inviolability is necessary cannot be answered on the basis of a theoretical analysis alone. In order to reach a conclusion on this issue, we will have to turn to an analysis of the current state of affairs and assess the institutional balance which inviolability is meant to ensure.

\section{The Immunity Regime of the Fifth Republic}

We have already seen that the two-tier immunity system of non-accountability and inviolability for members of both chambers of parliament has undergone relatively little change since the adoption of the constitutional documents of the Third Republic in 1875. After having discussed the evolution of the French immunity system in the 'constitutional laboratory' that France has been since the Revolution and the doctrinal superstructure in which it has been embedded, a closer look at the precise content of the two immunities will serve to clarify the exact extent of the protection which French parliamentarians enjoy. The text of Article 26 of the Constitution appears relatively straightforward at first glance, in particular when compared to the much less elaborate provisions of other systems such as the United Kingdom. Article 26 reads as follows:

No member of parliament may be prosecuted, investigated, arrested, detained or tried based on opinions expressed or votes cast by him in the exercise of his functions.

No member of parliament may be arrested or subjected to any other measure of a criminal or correctional nature depriving him of or restricting his liberty without the authorisation of the bureau of the Chamber to which he belongs. Such authorisation is not required in case of a crime or misdemeanour in flagrante delicto or in case of a final conviction.

The detention of a member of parliament, any measures depriving him of or restricting his liberty, or his prosecution shall be suspended for the period of the session if the Chamber to which he belongs so requires.

The affected Chamber shall convene by operation of the law for supplementary meetings in order to allow, where appropriate, the application of the preceding paragraph. 
A number of important questions do, however, remain with regard to the exact scope of the immunities. For instance, how exactly are the 'functions' of a parliamentarian defined? When exactly does the parliamentary mandate begin and when does it end - what is the temporal scope of the immunities? What is the procedure for lifting the inviolability of a member and which political and institutional implications does it have? Since we are particularly interested in the entanglement of parliamentary immunity with the constitutional and legal system as a whole, we also need to inquire into its legal nature: do we have to understand parliamentary immunity as a 'privilege' in the proper sense of the term - a system which creates a class of individuals which is exempt from the application of the general law? Or does it have to be understood as either an exculpation ground, a material exception to provisions of the (criminal) law or a mere procedural impediment? Finally, we shall attempt to answer the question whether there is a justification, beyond constitutional theory, for the element of inviolability which, after all, is the broadest immunity discussed in this study.

\subsection{The Constitutional Amendment of $\mathbf{1 9 9 5}$}

The current wording of the second paragraph of Article 26 of the Constitution is relatively recent. Until 1995, inviolability was significantly broader than it is today, since it barred for the duration of the parliamentary session not only the arrest of members but also any criminal proceedings against them. In the course of an extensive constitutional overhaul in 1995, 175 this prohibition of criminal prosecution was lifted. Prior to this amendment, the second paragraph read as follows:

No member of parliament may, for the duration of the session, be prosecuted in criminal or correctional matters without the authorisation of the Chamber to which he belongs. No member of parliament may, outside the session, be arrested without the authorisation of the bureau of the Chamber to which he belongs, except in case of an arrest flagrante delicto or pursuant to a final judicial sentence.

Thus, in addition to a complete bar on criminal prosecution during the session, the power to lift a member's inviolability was allocated with the respective chamber as a whole, though again only during the session. Outside the session, members could be prosecuted but not arrested, except flagrante delicto or following the authorisation by the chamber or a criminal sentence in final instance. During this period, the bureau of either chamber ${ }^{176}$ was competent to lift this freedom from arrest. The constitutional amendment of 1995 essentially limited the scope of inviolability to freedom from arrest both during and outside the session and rationalised the lifting procedure. 
Several reasons led to this significant limitation. First, the constitutional amendment also changed Article 28 of the Constitution, which previously provided for two ordinary parliamentary sessions per year, each of a duration of only up to three months. In addition to allowing only very limited parliamentary control of the government during half the year and an often rushed legislative process, these short sessions meant that members enjoyed the broadest form of inviolability only for six months a year and with an interval of three months between sessions. The constitutional amendment of 1995 prolonged the parliamentary session to nine months; it now lasts from October to June with no winter break. This would have meant a very significant broadening of inviolability if the immunity regime had not been amended simultaneously, introducing the longer session. Second, a series of corruption affairs ${ }^{177}$ and 'une certaine incompréhension de la part du citoyen $[\ldots]^{\prime},{ }^{178}$ which had previously also contributed to the decision to modify the constitutional provisions on the criminal responsibility of ministers, ${ }^{179}$ motivated the proposal to amend the immunity system. The explanatory memorandum attached to the amendment bill shows that the revision was meant to remedy a perceived institutional disequilibrium brought about by the extreme scope of inviolability:

[...] with a view to achieving a better equilibrium between the necessary protection of members of parliament and the observance of the rules of criminal procedure, the system of parliamentary inviolability is modified. Inviolability should be limited to the guarantees strictly necessary for the exercise of the parliamentary mandate. The requirement to obtain the authorisation of the Chamber before initiating the prosecution of a parliamentarian during the session is therefore abolished. However, the authorisation requirement for an arrest and the power of the Chamber to require the suspension of the prosecution or detention of a member are maintained. ${ }^{180}$

Thus, while freedom from arrest was still deemed necessary by the government which drafted the amendment bill, it felt that parliamentarians should, as far as possible in the light of this necessity, be subject to the rules of criminal procedure. ${ }^{181}$ The amendment was adopted on 4 August 1995 after receiving the required supermajority of two thirds in both parliamentary chambers.

\subsection{The Scope of Non-accountability and Inviolability}

In the following, the scope of non-accountability and inviolability will be considered in more detail. It is convenient to examine the temporal and personal scope of both immunities together, as the duration and capacity of the

Pactet \& Mélin-Soucramanien 2007, p. 443.

Isar 1994, p. 676.

Loi constitutionnelle No. 93-952 of 27 July 1993.

Projet de loi $\mathrm{n}^{\circ}$ 2120, exposé des motifs, 28 June 1995.

It has been argued that the constitutional amendment was not so much instigated by circumstantial pressure emanating from 'bad press' and public opinion but by the desire to modernise the parliamentary system as a whole; $c f$. Fraisseix 1999, p. 503. 
parliamentary mandate is the basis for both. The material scope of the immunities shall be considered individually, since it is here that the systemic divide between the two manifests itself.

\subsubsection{The Temporal Scope of the Immunities}

At first sight it does not seem too difficult to determine the temporal scope of nonaccountability and inviolability: the protection enjoyed by each parliamentarian on the basis of non-accountability sets in with the beginning of the mandate - the moment that the member assumes the capacity of parliamentarian - and lasts perpetually. This means that the protection afforded by this first layer of immunity extends beyond the duration of the mandate; members of the National Assembly and the Senate can never be held accountable for their votes and utterances in parliament. However, at one specific instance in history, this rule was not observed: after World War II, those parliamentarians of both chambers who had voted for the granting of full powers to marshal Pétain (see part two, section 3: the Vichy regime) were declared ineligible for the post-war parliament by a jury d'honneur. ${ }^{182}$

The application of inviolability is limited to the duration of the mandate. It sets in at the same time as non-accountability but ends with the expiry of the mandate. As a result, while measures depriving a parliamentarian of his liberty are barred ${ }^{183}$ for the period during which a person is a member of the National Assembly or the Senate, this person may be arrested or otherwise deprived of his liberty immediately after the termination of the mandate. It is important to note that such measures may then also relate to criminal acts or misdemeanours committed during the time of the mandate: inviolability only defers the arrest temporarily.

In the case of inviolability, it is also important to note that paragraph two of Article 26 of the Constitution, prohibiting arrests or other measures depriving parliamentarians of their liberty, applies both during the session and in between sessions. ${ }^{184}$ However, the suspension of detention or prosecution of a member according to paragraph three of Article 26 can only be demanded for the duration of the session.

As both immunities only start to apply at the moment that a citizen becomes a member of the National Assembly or a senator, it is important to determine exactly the moment at which membership of parliament begins. As inviolability ceases to apply at the end of the mandate, the moment of termination of the mandate is also of interest. One might expect that the mandate begins with the day on which the election results are announced. However, at least for the Senate this does not seem to be the case. Half of its members are elected every three years (series 1 and 2), so

Avril \& Gicquel 2010, p. 50.

Unless they are authorised by the respective chamber or its bureau, as the case may be.

The term 'session' refers to both ordinary and extraordinary or supplementary sessions. Cf. Calvo 1995, p. 7-11. 
that the mandates of senators do not all start and end at the same time. ${ }^{185}$ Article LO277 of the electoral code provides as follows:

In each series, the mandate of the senators begins with the opening of the ordinary session which follows their election. At the same time, the mandate of the senators previously in office expires.

One could possibly argue that the term 'member of parliament' in Article 26 of the Constitution can be construed to mean any citizen elected a member. However, this interpretation does not appear very convincing, since ultimately the notion of a member of parliament not (yet) equipped with a parliamentary mandate and not yet performing any parliamentary tasks makes little sense. It may thus be the case that a senator-elect, whose election has been proclaimed, does not yet enjoy parliamentary immunity, since his mandate has not yet begun. This is self-evident for non-accountability, whose application is only possible with regard to parliamentary acts and utterances (see below). With regard to inviolability, the fact that there can be a time gap between the announcement of election results and the moment at which the immunity starts to apply can be significant in cases where a senator-elect has not yet taken up his mandate.

The situation for members of the National Assembly seems to be the same, although here the electoral code does not explicitly mention the mandate of its members, but simply provides, in Articles LO121 and LO122 respectively:

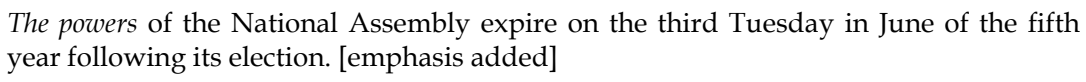

Except in case of dissolution [of the Assembly], general elections take place during the sixty days preceding the expiry of the powers of the National Assembly.

If we may assume that the parliamentary mandate of a newly elected member cannot commence before the 'powers' of the outgoing assembly have expired, a situation could arise in which a newly elected member is entitled to a mandate but that mandate has not yet begun. If election results are announced before the end of the last session of the outgoing assembly, this will mean that the newly elected members do not yet enjoy parliamentary immunity. This appears, on the one hand, from the fact that the number of members is fixed to 577 members by Article LO119 of the electoral code, to the effect that a brief period of a 'double assembly' is not only technically inexpedient but legally impossible. ${ }^{186}$ On the other hand, if the members-elect were to enjoy immunity without 'their' assembly having been convened yet, this would place any request to lift the inviolability of a member-elect at the disposal of the outgoing assembly. ${ }^{187}$ Considering the possibility of changing 
political majorities between the outgoing and the new assembly, this appears highly undesirable. As is the case for senators, non-accountability before the beginning of the mandate would be completely immaterial for the members-elect, as they do not perform any parliamentary tasks before taking up their mandate.

In addition, it should be noted that a pending review of election results for (a member of) either chamber by the Constitutional Council does not have suspensive effect according to Articles LO182 and LO325 of the electoral code. A member whose election is under review may therefore take up his mandate and consequently enjoy parliamentary immunity.

In conclusion, we may assume that that both immunities apply from the moment that the parliamentary mandate begins, and not the moment that election results are published. The mandate starts, in simple terms, at the moment that the member begins to take part in parliamentary activity. From the beginning of the mandate onwards, non-accountability applies perpetually whereas inviolability ends with the expiry of the mandate.

\subsubsection{The Personal Scope of the Immunities}

The personal scope of both non-accountability and inviolability is strictly limited to the member of parliament himself. It does not extend to his family or his staff. ${ }^{188}$ It is noteworthy that 'places frequented by the parliamentarian' as well his domicile and goods are also not protected by parliamentary immunity. ${ }^{189}$ While Isar made this observation before the constitutional amendment of 1995, it appears to be unaffected by the changes to Article 26 of the Constitution. It follows from the limitation of the scope of the immunities to the person of the parliamentarian proper that even such places and material which are attached to the person and can be characterised as 'parliamentary' are not covered. Nothing indicates, for instance, that parliamentary offices and documents are off-limits to measures of prosecution and investigation against a member of parliament, ${ }^{190}$ while such prosecution itself is no longer impeded by inviolability even during the session. It is clear that immunity would in any event bar legal proceedings and measures of investigation against a member on the basis of such documents if they fell under the material scope of nonaccountability (see section 2.4). However, it is noteworthy that, after the constitutional amendment of 1995, criminal measures against a member on any extraprofessional grounds are perfectly allowed as long as his physical liberty remains unaffected and as long as the relevant chamber has not made a demand under paragraph three of Article 26 of the Constitution.

Isar 1994, p. 681-682.

Ibid.

Searches of the parliamentary offices of senator Charles Ceccaldi-Reynaud (10 February 2004 and Assembly member Joëlle Ceccaldi-Reynaud (9 April 2004) have been performed by an investigating judge (juge d'instruction). In case of the senator's office, this was done in the presence of the president of the Senate. Cf. Avril \& Gicquel 2010, p. 52. 
Only relatively recently, with the adoption of the act of 14 November 2008, ${ }^{191}$ has one important exception to the strict limitation of non-accountability to the person of the member been introduced. This act introduced an extension of nonaccountability, by virtue of Article 41 of the Act of 29 July 1881 on the freedom of the press, to the testimony of any person heard as a witness by a parliamentary enquiry committee of the Senate or the National Assembly. This extension of nonaccountability, though very important to the work of enquiry committees, was previously not accepted by the courts. ${ }^{192}$ The inserted provision reads as follows:

Neither any written or oral utterances made before an enquiry committee of the Senate or the National Assembly by a person asked to testify there, except where these utterances are unrelated to the object of the enquiry, nor any reproduction in good faith of the proceedings of public meetings of such an enquiry committee, give rise to any legal action for defamation, libel or insult.

This is a case in point of the argument that parliamentary immunity has at its aim the protection of parliament, not the parliamentarian as a person. Also in the French context, that is an argument frequently heard. ${ }^{193}$ On the one hand, this institutional reasoning is reinforced by the existence of freedom from arrest in criminal matters, which allows parliament to secure the presence of its members at all times, and the recent extension of non-accountability to committee witnesses. On the other hand, any provision which adds to the personal scope of immunity an 'institutional scope' by covering parliamentary buildings, documents, and also persons other than witnesses involved with parliamentary affairs who are not members is glaringly absent from the French immunity system. ${ }^{194}$ This stands in sharp contrast to the British system of parliamentary privilege, where the protection of 'proceedings in parliament' is given much more prominence than the protection of the members personally.

\subsubsection{The Material Scope of Non-accountability}

Non-accountability constitutes a legal immunity in the proper sense of the term. Its effect is absolute in that it prohibits any form of legal proceedings, civil or criminal, against a member for acts performed, votes cast or opinions uttered by him in the exercise of his parliamentary functions. We have already seen that it is also perpetual and does not end with the end of the mandate. The material consequences in cases where non-accountability applies are therefore clear: due to its perpetual effect, non-accountability means true legal impunity for the parliamentarian even if

Act No. 2008-1187 of 14 November 2008, modifying Art. 41 of the Act of 29 July 1881 and Art. 6 of Ordinance No. 58-1100 of 17 November 1958

Cour de Cassation, 22 February 1956, bull. civ., II, No. 137, p. 87.

Cf. for instance Fraisseix 1999, p. 497.

Perhaps with the exception of Art. 100-7 of the French code of criminal procedure which prohibits the tapping of a member's phone line without prior notification of the president of the chamber concerned, while the member himself does not have to be notified. 
his utterances are defamatory or injurious or incite murder or treason. ${ }^{195}$ Similarly, it is immaterial whether the parliamentary act or utterance causes any damage. ${ }^{196}$ The absolute nature of non-accountability is not hampered by the fact that nonaccountability is deemed to be offset, though not legally enforceable outside the chamber, by a devoir de reserve which obliges members to mitigate the tone and content of their utterances in parliament. ${ }^{197}$

But what exactly is protected by non-accountability for 'opinions expressed and votes cased in the exercise of [a member's] functions'? After all, the term 'opinions' in the first paragraph of Article 26 of the French constitution is not much clearer than the British 'proceedings in Parliament'. It is generally given a wide interpretation, practically synonymous to 'utterances'. The protection of nonaccountability does not only extend to votes, speeches, questions and other oral interventions in the plenum of either chamber, but also to utterances made in committees, parliamentary groups or on parliamentary missions. ${ }^{198}$ Such utterances (or 'opinions') may be oral or written.

The wording of Article 26 of the French Constitution, as opposed to the wording of Article 9 of the English Bill of Rights 1689, leaves little doubt that the connecting factor which places an utterance under the protection of nonaccountability is not a spatial or geographical one: it is clear that 'parliamentary functions' are exercised not only in the hemicycle or the building of the chamber. With a view to Title IV and V of the constitution on parliament and the relations between parliament and the government, one may also include the proposal and signing of a motion of censure, the drafting (and the ensuing text) of a bill and similar acts and products of a parliamentarian in the list of possible ways of expressing an 'opinion in the exercise of [the] functions' of a member. ${ }^{199}$

If the term 'opinions' must be given a broad interpretation and if parliamentary 'functions' may be performed outside the parliamentary premises, this makes it hard to assess, in an individual case, whether a certain utterance falls under the material scope of Article 26(1) of the Constitution. As a rule to help determine whether non-accountability applies in a certain case, Isar has suggested that non-accountability only covers utterances (speech acts) of which only a parliamentarian is capable, due to his mandate. 200 Whether such a test will yield accurate results in all cases is doubtful. On the one hand, many speech acts can be

$195 \quad$ Isar 1994, p. 688.

196 Pactet \& Mélin-Soucramanien 2007, p. 443.

197 Transcript of the debates of the National Assembly, 2nd session of 3 November 1986, p. 5696; cf. Avril \& Gicquel 2010, p. 51.

198 Avril \& Gicquel 2010, p. 50. Note that the notion 'parliamentary missions' only means missions undertaken in a member's capacity as a parliamentarian. Missions with which a member is assigned by the executive are not covered; Cf. Vivien c/ Eglise de Scientologie, Cour d'appel de Paris 11 March 1987 and the corresponding case note by Bigaut 1989, p. 12. The Conseil Constitutionnel subsequently declared an act which would have placed reports emanating from such a government-assigned mission under the cover of non-accountability unconstitutional; Conseil Constitutionnel, 7 November 1989, No. 89-262 DC.

$199 \quad$ Isar 1994, p. 684.

$200 \quad$ Isar 1994, p. 689. 
imagined which can only be performed by parliamentarians because they require information to which only they have access. On the other hand, in such a case the exclusive capability does not actually relate to the speech act itself but to certain prerequisites for that act. If all such cases were to be covered by non-accountability, this would lead to results which are, in all likelihood, politically unacceptable: imagine, for instance, that parliamentarians - only parliamentarians - have access to certain classified information from non-public committee meetings or other sources inaccessible to non-members and that they disseminate or 'leak' such information to the press. According to the test proposed by Isar, at least if we interpret the 'exclusive capability' requirement generously, non-accountability would easily protect parliamentarians who engage in 'leaking' and betrayal of state secrets. This however, will in all likelihood be hard to defend as being done 'in the exercise of [a member's] functions'. For determining whether or not a certain act is covered by non-accountability, therefore, the 'exclusive capability' test is only useful if that requirement is indeed given a restrictive interpretation. On a side note, the recent extension of non-accountability to committee witnesses and their testimony has added an exception to the rule that only parliamentarians can enjoy nonaccountability (see above). By means of an exception to this exception, however, non-accountability for committee witnesses has been limited to such utterances as are related to the object of the enquiry. It is not hard to imagine a scenario in which the latter condition is excessively hard to test for a judge confronted with a committee witness accused of criminal speech.

The definition of 'parliamentary functions' is relatively narrow. The term does include literal reproductions of parliamentary utterances and documents in the press $^{201}$ as well as discussions of such utterances by journalists in good faith. ${ }^{202}$ It does not, however, extend to utterances and written statements by a parliamentarian in newspaper or journal articles or at public gatherings. ${ }^{203}$ Statements of parliamentarians in radio or television broadcasts, where it does not concern direct transmissions of the parliamentary session, are not covered by nonaccountability. ${ }^{204}$ Case law has confirmed that this is the case even where a parliamentarian is invited to take part in a television debate in his capacity as head

201 Art. 41 of the Freedom of the Press Act (loi sur la liberté de la presse) of 29 July 1881, as amended by loi no. 2008-1187 of 14 November 2008:

'Ne donneront ouverture à aucune action les discours tenus dans le sein de l'Assemblée Nationale ou du Sénat ainsi que les rapports ou toute autre pièce imprimée par ordre de l'une de ces deux assemblées.

Ne donnera lieu à aucune action le compte rendu des séances publiques des assemblées visées à l'alinéa ci-dessus fait de bonne foi dans les journaux.

Ne donneront lieu à aucune action en diffamation, injure ou outrage ni les propos tenus ou les écrits produits devant une commission d'enquête créée, en leur sein, par l'Assemblée Nationale ou le Sénat, par la personne tenue d'y déposer, sauf s'ils sont étrangers à l'objet de l'enquête, ni le compte rendu fidèle des réunions publiques de cette commission fait de bonne foi [...]'.

Chantebout 2007, p. 498

Avril \& Gicquel 2010, p. 52.

Calvo 1995. 
of a parliamentary inquiry committee on the issue of that committee. The Tribunal de grande instance de Paris held that Jacques Guyard, chairman of an inquiry committee of the National Assembly on religious sects, could not rely on parliamentary nonaccountability as a defence in defamation proceedings against him. Mr. Guyard had referred to the anthroposophy movement as a 'sect' in a television interview, thereby repeating the content of a committee report. The Court reasoned as follows:

\footnotetext{
The circumstance that Mr. Guyard has been invited to speak in his capacity of president of the enquiry committee on sects does not suffice to give his contribution the character of an act of the parliamentary function; consequently, the statements of the defendant - uttered outside the parliamentary premises - cannot be regarded as a prolongation of the report drafted by the committee. ${ }^{205}$
}

While this ruling was not upheld on appeal, the cour d'appel based its decision on the merits of the defamation case (it held that the anthroposophy movement could legitimately be referred to as a 'sect') and not on parliamentary nonaccountability. ${ }^{206}$ The reasoning of the lower court therefore seems to remain intact on the issue of the applicability of non-accountability.

Similarly, utterances of parliamentarians are not protected by nonaccountability where they are done in the context of an assignment which a member has been given by the government. ${ }^{207}$ This has been decided by the Constitutional Council on the basis of the argument that, while such missions are compatible with the parliamentary mandate, they are by no means part of it: ' [...] la rédaction d'un rapport, à la demande ou pour le compte du Gouvernement, diffusé sur son ordre, ne semble pas pouvoir être rattachée à l'exercice du mandat parlementaire' ${ }^{208}$

We can conclude that the material scope of non-accountability is demarcated rather strictly along the boundaries of a parliamentary mandate which is not deemed to include communication with the outside world, other than indirectly through broadcast debates or through documents officially sanctioned by parliament. The only point where the application of non-accountability crosses this boundary and goes beyond the parliamentary mandate is the exception adopted very recently for witnesses in inquiry committees mentioned earlier. This strict demarcation limits the material scope of non-accountability significantly and can be seen as a counterweight to the unlimited duration of this immunity.

\subsubsection{The Material Scope of Inviolability}

On top of non-accountability, which protects the work of a member of parliament itself, inviolability is a measure of 'protection of the physical and intellectual liberty

205 Guyard, Tribunale de grande instance de Paris, 21 March 2000

206 Cour d'Appel de Paris, 6 September 2001, No. 00-02776.

207 While membership of the government is incompatible with the parliamentary mandate, temporary government assignments are compatible with it according to Art. LO144 of the code électoral.

208 Conseil Constitutionnel, 7 November 1989, No. 89-262 DC. 
of parliamentarians', ${ }^{209}$ whereby the 'intellectual' protection must be understood as an indirect one: members are not to be troubled by fear of an imminent arrest or, under certain circumstances, measures of criminal prosecution. It is argued that,

\begin{abstract}
It is perfectly conceivable that the political adversaries of a parliamentarian seek to destabilise him by prosecution (which will often turn out to be unfounded), if not even to prevent him from taking his seat in parliament by arranging for his arrest while in reality he cannot be blamed with anything, or, simply, by exerting pressure on him by simple threats. ${ }^{210}$
\end{abstract}

While preventing this is certainly the declared aim of both non-accountability and inviolability, the material scope of the latter is also not unlimited. As we have seen, inviolability can be characterised as a temporary and provisional immunity. Temporary, because it is limited to the duration of the parliamentary mandate and because the right of the chambers to demand a stay of measures of prosecution against a member or to have him released from detention pursuant to paragraph three of Article 26 of the Constitution is limited to the duration of the session. Provisional, because the immunity may be lifted by the bureau of the chamber concerned at any time and because it does not apply in case of an arrest flagrante delicto or upon a criminal sentence pronounced in final instance.

In principle, the acts covered by inviolability are acts which qualify as crimes or misdemeanours (délit) committed in the extraprofessional sphere, id est, outside the immediate scope of activities which can be attributed to the parliamentary mandate. Evidently, this means that the simultaneous application of nonaccountability and inviolability to the same act or utterance is impossible.

Avril and Gicquel define the sphere of application of inviolability as encompassing 'anything which may be examined by an investigative judge [magistrat instructeur] under the conditions of the general law'.211 Conversely, inviolability prohibits for the entire duration of the mandate the arrest of a member of parliament and any other measures of a criminal or correctional nature which deprive him of or limit his liberty. These 'other measures' have been added to paragraph two of Article 26 by the constitutional amendment of 1995, taking into account the implications of an earlier amendment made in 1970 to Article 138 of the code of criminal procedure. That amendment introduced 16 measures of contrôle judiciaire, to be imposed on a suspect by the investigative judge, among which some limit the freedom of the suspect. ${ }^{212}$

It is important to note that the freedom from arrest effected by inviolability only concerns deprivation of liberty in criminal and correctional matters. Certainly, arrest in civil matters has long been abolished in France as it has been elsewhere. Situations in which a member of parliament could be deprived of his liberty other than in criminal matters are nonetheless conceivable, if yet unlikely. For instance, it

Hamon \& Troper 2009, p. 675.

Luchaire \& Conac 1980, p. 793

Avril \& Gicquel 2010, p. 52.

For instance, the investigative judge may order a suspect not to leave his place of residence, not to visit certain places, etc. 
would be imaginable that a parliamentarian is placed under quarantine or taken into custody on grounds of his mental health. In contrast to the situation in the UK, where this possibility needed to be made explicit by statute for members of the House of Commons and is still not finally decided for members of the House of Lords, Article 26 of the French Constitution sets a very clear boundary.

In addition to the prohibition of arrest which applies throughout the time of the mandate, the chamber concerned may demand the release of a detained member or the stay of any measures of investigation or pursuit against time for the duration of the session (paragraph three). Since this demand cannot be made by the bureau but only by the full chamber, supplementary sessions may be convened to make such a demand. Thus, subject to the condition that a political majority must be obtained for the chamber to make this demand, a member can still enjoy complete freedom from any measure of criminal investigation for the duration of the session and can even be released from detention where it does not concern imprisonment as the consequence of a final judicial sentence.

As regards the material scope of inviolability, we can conclude that it presents itself as a broad but by no means limitless immunity. Most importantly, any effect it has ceases with the end of the parliamentary mandate. During the time of the mandate, however, it automatically bars the application of the criminal law only as far as it would lead to a deprivation of liberty. Criminal investigations, trials and detention not based on a final criminal sentence can be suspended only at the behest of an active intervention by the chamber concerned.

\subsection{Procedures for Lifting Inviolability and for the Suspension of Detention or Prosecution}

\subsubsection{The Procedure for Lifting Inviolability}

When considering the lifting of parliamentary immunity, we should first consider that neither of the two layers of immunity is placed at the disposal of the individual parliamentarian himself, that is to say, a member can under no circumstances waive his immunity. This appears logical in the light of the thought that immunity is not considered a personal privilege of the individual member as a person but a means to safeguard the functioning of parliament as an institution.

As has been mentioned previously, non-accountability is perpetual and cannot be lifted, while inviolability is temporarily limited and can be lifted at the behest of the chamber or bureau. This means that, save in cases of arrest flagrante delicto ${ }^{213}$ or after a member has incurred a final criminal sentence pursuant to which the arrest is made, any arrest or other criminal measure restricting the liberty of a

213 Avril and Gicquel observe that this notion has at times been subject to abuse. They cite the curious case of Jacques Duclos, member of the National Assembly for the communist party. During a time of violent protests, two pigeons were found in his car on 28 May 1952 Subsequently he was accused of using the birds to give secret instructions to the protesters and the lifting of his inviolability was requested. Later, it was established that the pigeons were rather normal birds and by no means secret messengers. Cf. Avril \& Gicquel 2010, p. 54. 
parliamentarian requires prior authorisation. Such authorisation must, on sanction of nullity, be requested in writing by the procurator general at the competent court of appeal and transmitted, via the minister of justice, to the president of the chamber concerned.214 The steps of this line of communication must be strictly observed: it has repeatedly been reiterated that the minister of justice is the only interlocutor' that the Senate recognises in such matters; ${ }^{215}$ the same procedure applies to requests made to the National Assembly. Requests must indicate precisely for which measures authorisation is requested, unless the request relates to all possible measures; 216 requests to the Senate must also indicate the motives which the request is based on. ${ }^{217}$

In both chambers, the decision whether the requested authorisation is granted is taken by the respective bureau alone, which is seized by the president of the chamber upon receipt of the request; no debate or vote is held in the plenum of the chamber as was the case before the constitutional amendment of 1995 . In the National Assembly, the request will be dealt with and the decision prepared by a committee formed within the bureau, while no such delegation takes place in the bureau of the Senate. ${ }^{218}$ Finally, where the authorisation is granted, it is limited to the measures explicitly mentioned in the request. ${ }^{219}$ In reality, this procedure can and does lead to a partial lifting of inviolability. This happens either where the request is formulated in such a way that authorisation is sought for only one or several specific measures or where an initial request is turned down by the bureau and subsequently reformulated, as it happened in the case of the assembly member Bernard Tapie in 2001, where the bureau resolved that measures of contrôle judiciaire ${ }^{220}$ should suffice for the due administration of justice. ${ }^{221}$

It is not without a certain irony that the constitutional revision of 1995, while reducing the scope of inviolability significantly, has had one very important side effect which results from the new lifting procedure: requests to lift inviolability are no longer publicly debated in the plenary chamber. As a result, there is now much less opportunity for - or danger of, as perspectives change - public scrutiny and media attention. This may, on the hand, have a positive effect, since it has been observed that, under the previous system,

Art. 9 bis of Ordinance No. 58-1100 of 17 November 1958.

Avril \& Gicquel 2010, p. 53.

Art. 16 of the Instruction Général du Bureau (IGB) of the National Assembly and Art. III bis of the IGB of the Senate, respectively.

Ibid.

Ibid.

Art. 9 bis para. 2 of Ordinance No. 58-1100 of 17 November 1958.

Cf. supra at 212.

Avril \& Gicquel 2010, p. 53. 
The parliamentarian concerned will inevitably see how the decision to lift his immunity is interpreted as an implicit recognition of his guilt: conversely, the decision to refuse the lifting of his immunity or the inadmissibility of the request will be perceived as an evasive maneuver with the aim of delaying judicial action (...).222

This effect is certainly mitigated by excluding the public and the media from the decision making process, which may also have the effect that votes on a request to lift inviolability are less likely to be influenced by public opinion and thus, it is hoped, more likely to be based on merits. On the other hand, the constitutional overhaul of 1995 had the aim of bringing the legal situation of a member of parliament more in line with that of an ordinary citizen. It is questionable whether the enormous reduction in transparency which comes with the new lifting procedure works towards that end. On the one hand, the prosecution of an ordinary citizen is usually, and rightfully, not publicly scrutinized before the trial. On the other hand, however, inviolability can be a powerful and, lacking the political will in parliament to overcome it, insurmountable obstacle to the judicial process which ordinary citizens certainly do not have in their arsenal.

\subsubsection{The Procedure for the Suspension of Detention and Measures of Prosecution}

Paragraph one of Article 80 of the Rules of Procedure (règlement) of the National Assembly stipulates that a permanent immunities committee of 15 members be formed for the purpose of examining demands to suspend the detention, measures restricting the liberty, or the prosecution of a member. The political composition of this committee must be proportionate to that of the assembly. In the Senate, an ad hoc committee composed of 30 members, also representing the composition of the Senate proportionally, exercises the same task by virtue of Article 105 of the Rules of Procedure of the Senate. The member concerned or (for example, if that member is in detention) a colleague authorised by him may submit to this committee a request to make a demand pursuant to Article 26, paragraph three of the constitution. After hearing the member or his agent, the committee prepares a draft resolution which it submits to the respective plenary chamber.

Paragraph seven of Article 80 of the Rules of Procedure of the National Assembly provides that a limited oral debate shall take place on the basis of the draft resolution, at which only the rapporteur of the committee, a representative of the government, the concerned member himself or his agent, as well as one speaker pro and one speaker contra may have the floor. A subsequent vote in the assembly adopts or rejects the demand. If it is rejected, no further request with regard to the same matter may be made for the remainder of the session, pursuant to paragraph nine of Article 80.

The procedure in the Senate, ex Article 105 of its Rules of Procedure, is regulated far less strictly. Article 105 does not provide for any limitations to the oral

222 Rapport No. 2138 of the commission des lois, 5 juillet 1995, p. 27, as quoted by Fraisseix 1999, p. 538 . 
debate in the Senate; however, the chamber may, similarly to the assembly, only vote on the suspension of the detention or other measures in question. This means that it may decide the full or partial suspension of these measures but may, for instance, not determine the duration of the suspension or issue an opinion on the merits of the case.

If a decision to demand a suspension pursuant to paragraph three of Article 26 of the Constitution is taken by either chamber, that suspension is only effective during the remainder of the current session.

\subsection{The Legal Nature of Parliamentary Immunity}

The question of the legal nature of immunity appears particularly interesting in the light of a comparison between the immunity systems of different countries, since it is a strong indicator of the place that immunity takes within the legal system as a whole. Different interpretations of this legal nature are possible. Especially with regard to speech acts which in themselves qualify as criminal but which are covered by non-accountability, one could think of irresponsabilité as an exculpation ground, which does not take away the criminal nature of the act but renders the perpetrator inculpable by virtue of his parliamentary mandate. One could also think of it as a legal justification, similar to legitimate defence or necessity.223 Finally, and perhaps most logically, non-accountability can be perceived as a 'real' immunity, in the sense that it creates a class of people generally exempt from the application of certain provisions of the general law where they would apply to acts attached to their parliamentary mandate.

The legal outcome for the parliamentarian would be the same, regardless of which legal nature is assumed for non-accountability. Nevertheless, it might have consequences for the way in which criminal proceedings against members are conducted in court. If non-accountability is either merely an exculpation ground or a justification, the criminal judge would still have to establish the alleged act and its criminal nature in principle, before he could apply paragraph one of Article 26 of the constitution. If, on the other hand, non-accountability is to be understood as an immunity in the proper sense of the word, proceedings would have to be abandoned the moment it is established that the defendant is a member of parliament and the act concerned falls under his parliamentary activity. It appears most reasonable to assume that the latter interpretation of non-accountability is the correct one, which is also confirmed by court practice and the opinion of practitioners. 224 As a result, the difference between French parliamentary nonaccountability and British parliamentary privilege does not seem too large and lies mainly in the material scope of UK privilege, which covers all "proceedings in Parliament', regardless of the person involved.

The legal nature of inviolability is very different from that of nonaccountability. We have repeatedly mentioned that inviolability neither de-

Isar 1994, p. 685.

Isar 1994, p. 686. 
criminalises the criminal act committed by a parliamentarian nor affects the culpability of the perpetrator. It is also not what we have called an 'actual immunity', since legal proceedings remain possible at all times and may, in case of a final sentence, even result in incarceration during the time of the mandate. More importantly, inviolability never has more than a deferring aspect. After the end of the mandate at the latest, prosecution and arrest can proceed as provided by the criminal law. Therefore, it is best to understand inviolability as a mere procedural impediment, rather than an immunity in the strict sense.

\subsection{A Justification for Inviolability?}

We have seen in part III that a justification of inviolability on the basis of mere theoretical considerations is probably too weak to sustain the system as it exists in reality. First, this justification is largely based on the logic of the doctrine of national sovereignty and a very strict notion of the representative mandate which ensues from it. However, this doctrine is no longer rooted in the text of the constitution, nor is it reflected in the actual institutional structure of the state. To accept parliamentary immunity of formal grounds as a necessary corollary of national sovereignty is therefore insufficient to justify the legal phenomenon of parliamentary immunity as it exists in practice. Second, the argument that the legislature must be complete in order to perform its task of defining and formulating the national will can be refuted, since there is no need under the theory of representation for the legislature to reflect the political will of the electorate. ${ }^{225}$ Perhaps more importantly, parliamentary practice does not suggest that the absence of a member is an impediment to decision making, as long as the relevant quorum for a particular decision is present. Thus, if completeness of the chambers of parliament alone does not justify inviolability, do other considerations justify it?

Two arguments may, in fact, contribute to a justification. First, inviolability reinforces the institutional equilibrium and maintains the balance of power between the judiciary and the legislature. Keeping in mind that inviolability is temporary and only effective as long as a citizen is indeed part of a legislative organ, a justification of inviolability from this angle is conceivable. However, it is doubtful whether such a justification suffices in times where the assertiveness of parliament vis-à-vis the judiciary is not so much fuelled by actual conflict or threat as it is a 'corporate reflex'. ${ }^{226} \mathrm{~A}$ much more important institutional argument in favour of maintaining inviolability can be derived from the fact that the public prosecution service (ministère public) is not entirely independent and even bound by direct instructions from the government. Article 30 of the code of criminal procedure provides that the Minister of Justice is not only competent to formulate policy rules with regard to prosecution but to order the commencement of proceedings in a case.

225 Cf. Guérin-Bargues 2011, p. 117 et seq.

226 Guérin-Bargues 2011, p. 371. 
The Minister of Justice carries out the policies of public prosecution determined by the government. He ensures the coherence of its application throughout the territory of the Republic.

To this end, he issues general instructions of public prosecution to the members of the prosecution service.

He may report any violations of the criminal law of which he has knowledge to the procurator general and order him, by means of written instructions deposited in the case record, to initiate proceedings or to cause them to be initiated, or to seise the competent court [jurisdiction] of such written orders as the minister deems appropriate.

This involvement of the government with the ministere public is more worrying in terms of the separation of powers and institutional balance, since the government and, in particular, minority members of the legislature may pursue opposing interests which could potentially lead to politically motivated proceedings. Several authors share this worry and therefore find inviolability, at least to a certain extent, justified. ${ }^{227}$

\subsection{The Immunity Regime of the Fifth Republic: A Summary Picture}

In this part, we have described the current French immunity regime which presents itself as a two-tier system of two complementary elements: non-accountability and inviolability. Non-accountability is an immunity in the strict sense of the term: it permanently bars the application of the general law to a certain group of people acting in a specific function. Inviolability, however, is better understood as a temporary procedural impediment which is neither permanent in terms of its temporal scope nor absolute, since it can be lifted. Both immunities cannot, at any time, be waived by an individual member.

We can observe that, even looking at a relatively small timeframe of less than 20 years, the system of parliamentary immunity in France is anything but static. A major constitutional amendment has significantly reduced the material content of inviolability and changed the lifting procedure from a plenary vote to a more discrete decision of the bureau. Non-accountability has been slightly broadened in 2008 by including non-members who testify in parliamentary inquiry committees as witnesses. On a general note, one may conclude that the French immunity regime has recently undergone a modernisation process aiming at adapting it to a more modern understanding of representative democracy and responding to current needs.

Whether inviolability, certainly the more contentious element of immunity, is fully justified in its current form might be doubted. However, institutional arguments show that its complete abolition is not called for, as it still plays a role, at least potentially, in maintaining an institutional balance and safeguarding the separation of powers. 


\section{Conclusion}

The comprehensive analysis of the French parliamentary immunity system undertaken in this chapter has spanned a period of more than two hundred years and a wide array of individual aspects of immunity.

In contrast to parliamentary privilege in the United Kingdom, the origins of the French immunity system do not lie in the mists of medieval history but can be traced to two exact dates in the early days of the French Revolution. The historical background of the two first immunity decrees of the National Assembly of 23 June 1789 and 26 June 1790 leaves no doubt that the immunity system was initially adopted out of circumstance, for fear of reprisals and to assert the independence of the young Assembly. Even though the Assembly did not clearly distinguish between the two different forms of immunity, the two-tier system of nonaccountability and inviolability which remains in place to this date has its historical basis in these two decrees. Since the Revolution and throughout the French 'waltz of constitutions', this system has undergone remarkably little change. It is therefore fair to say that, in France, parliamentary immunity is a very stable and timehonoured constitutional tradition.

One of the reasons why the two-tier system of non-accountability and inviolability has proven so surprisingly persistent despite its evidently circumstantial origin can be found in constitutional theory. Classical French doctrine has created an intimate - though largely implicit - link between parliamentary immunity and two core concepts of French constitutional thinking: national sovereignty and representation. According to classical reasoning, the idea that the national will has to be formed by completely independent representatives of the nation and that this justifies and requires the severance of any (legal) link between parliament and the outside world. Parliamentary immunity is an essential tool to safeguard this complete independence. In short, national sovereignty requires a representative parliamentary mandate, which requires absolute independence, which in turn requires parliamentary immunity. This line of reasoning relies on legal fictions which the French Constitution had already factually abandoned at the time it was formulated by Carré de Malberg and others. It is nevertheless still the near-axiomatic justification for parliamentary immunity in France and has only recently received some criticism. In particular, it has been argued that non-accountability remains essential for the functioning of parliament, but that the classical justification of the immunities is weak with regard to inviolability because it relies on assumptions which do not match the conditions of today's constitutional and political reality.

Despite its historical stability, the French immunity regime is not static. The constitutional amendment of 1995 has severely limited the material scope of immunity; members of parliament can now be prosecuted without the prior authorisation of the chamber concerned. While both chambers remain able to suspend the prosecution of one of their members, the default inviolability has thus essentially been reduced to freedom from arrest. According to the explanatory memorandum, the aim of the amendment was to limit inviolability to the 
guarantees strictly necessary for the exercise of the parliamentary mandate'. On a larger scale and seen in conjunction with recent doctrinal calls for a more practical approach to the justification of parliamentary immunity, the development of the French immunity systems seems to match our hypothesis (see Chapter II, section 4) that immunity regimes have a general tendency to develop in the direction of a slowly developing European standard whose core is a functional approach to immunity. Under this approach, inviolability is especially problematic where it exceeds the level of protection which is necessary to protect the functioning of parliament. However, with general freedom from arrest and the power of parliament to suspend criminal proceedings against its members at will, France still roams near the upper end of the 'immunity scale'. 

Chapter 5

\section{PARLIAMENTARY IMMUNITY IN THE NETHERLANDS}

\section{Introduction}

\subsection{Structure}

After an introduction (part one), this case study is split into three parts. As in the previous case studies, part two explores the origins and history of parliamentary immunity. Part three discusses the Dutch immunity system as it applies today. This part also pays particular attention to an often neglected or 'dormant' constitutional provision of only potential relevance to parliamentary immunity: Article 119 of the Dutch Constitution. This part also contains a discussion of recent debates with regard to broadening the scope of the immunity system. The final part, part four, contains the conclusions which can be drawn from a comprehensive analysis of the Dutch immunity regime.

\subsection{Terminology}

The most frequently used Dutch terms for parliamentary immunity are parlementaire immuniteit and parlementaire onschendbaarheid. The latter term is often used to refer to the immunity laid down in Article 71 of the Constitution. It has, however, been identified as misleading, ${ }^{1}$ since it literally translates into 'inviolability' whereas Article 71 only provides for non-accountability. Thus, the term onschendbaarheid suggests a degree of immunity which the Dutch Constitution does not offer to members of the States-General. In addition, the same term is used to denote the actual inviolability of the Dutch monarch ex Article 42(2) of the Dutch Constitution, which is much more substantial.

Belgian authors, writing about the Belgian immunity system (which is very similar to the French one), often speak of onverantwoordelijkheid when discussing non-accountability as opposed to onschendbaarheid, by which they mean 
inviolability. ${ }^{2}$ This term is not generally used in Dutch literature, presumably because using the term onverantwoordelijk in the context of immunity results in an involuntary pun: it translates into both 'unaccountable' and 'irresponsible'. Where not accompanied by a precise explanation of the legal content of parliamentary immunity in the Netherlands (which is hard enough to give!), it is imaginable that the ambiguity of the term onschendbaarheid causes misconceptions and thus may contribute to an often observed overestimation of the degree of immunity enjoyed by members of the States-General. ${ }^{3}$

A term which has sometimes been used in Dutch literature to denote inviolability or, more specifically, freedom from arrest, is vrijwaring. This term has several slightly different meanings depending on the context in which it is used, but translates roughly into 'guarantee'. ${ }^{4}$ In the context of early Dutch immunity provisions, it could be understood as a guaranteed right to personal liberty (freedom from arrest), or a right of free passage.

\subsection{Parliamentary Immunity in the Netherlands}

The present case study is concerned with the system of parliamentary immunity of the Netherlands. As with the two previous case studies, this means that the primary object of study is the immunity which applies to members of the upper and lower chambers of the national parliament. In the case of the Netherlands, these are the First and Second Chamber of the States-General, respectively. The current Dutch system of parliamentary immunity is essentially limited to non-accountability, which is laid down in Article 71 of the Constitution. This reads as follows:

The members of the States-General, the ministers, the secretaries of state and other persons who participate in deliberations may not be prosecuted or held liable for what they have said in the meetings of the States-General or of committees thereof, or for what they have submitted to them in writing. ${ }^{5}$

The persons thus covered by Dutch non-accountability are not only the members of the two chambers of the States-General but also the ministers, secretaries of state (also referred to as 'junior ministers' in the Netherlands) and 'other persons who participate in deliberations'. Accordingly, non-accountability has a wide personal

See for instance Sottiaux 2010, p. 50 .

This overestimation has been discussed in Drexhage 2011, p. 65-82.

In private law, for instance, the term vrijwaring can denote the duty of the seller of a good to guarantee the buyer the free and full enjoyment of the sold good. If it turns out that a third party is entitled to the good, this may result in an obligation of the seller to compensate the damage suffered by the buyer; in civil procedure, the possibility to seek redress from a third party is also referred to as vrijwaring.

Translation from Kiiver \& Kornet 2010. The Dutch original reads as follows:

'De leden van de Staten-Generaal, de ministers, de staatssecretarissen en andere personen die deelnemen aan de beraadslaging, kunnen niet in rechte worden vervolgd of aangesproken voor hetgeen zij in de vergadering van de Staten-Generaal of van commissies daaruit hebben gezegd of aan deze schriftelijk hebben voorgelegd'. 
scope which reaches beyond actual members of parliament. In part, this is certainly explained by the incompatibility of the parliamentary mandate with government office: ministers and secretaries of state may not be members of the States-General. At the same time, however, the government is part of the Dutch legislature. Ministers and secretaries of state will therefore regularly take part in legislative debates in parliament. It would therefore appear absurd to deny them the same freedom of speech as is enjoyed by parliamentarians, at least if parliamentary immunity is to be understood as the legislator's privilege.

In the Netherlands, no additional layer of inviolability is available on top of the non-accountability provided by Article 71, with one possible qualification: Article 119 of the Constitution designates the Supreme Court as a forum privilegiatum for the trial of crimes committed in office. The provision reads as follows:

The members of the States-General, the ministers and the secretaries of state are tried for crimes committed in these capacities before the Supreme Court, also after having left office. The order to prosecute is given by royal decree or by a decision of the Second Chamber. 6

This provision thus prescribes a special procedure for the prosecution and adjudication of crimes committed by the designated persons in the exercise of their office or mandate. Article 119 bears a certain resemblance to provisions which regulate the criminal liability of members of the government in the constitutions of other countries. ${ }^{7}$ The existence of such provisions is normal in countries where government office is incompatible with the parliamentary mandate, as this means that members of the government do not enjoy parliamentary immunity. However, such provisions are not normally mutually applicable to parliamentarians but constitute a separate and usually more limited immunity regime for the government alone. ${ }^{8}$

Article 119 of the Dutch Constitution certainly does not create an immunity stricto sensu, since it does not even temporarily bar legal proceedings and only applies to a limited set of criminal acts, referred to as crimes in office [lit: 'office crimes' - ambtsmisdrijuen]. It is nevertheless reasonable to consider Article 119 in a comprehensive analysis of parliamentary immunity. On the one hand, our account of the history of the Dutch immunity regime will show that Article 119 is a constitutional remnant of actual inviolability, which existed in the early $19^{\text {th }}$ century but later disappeared. On the other hand, it has been claimed that Article 119 bears at least a hypothetical 'immunity potential', even though it has never been applied

6 Translation: ibid. The Dutch original reads as follows:

'De leden van de Staten-Generaal, de ministers en de staatssecretarissen staan wegens ambtsmisdrijven in die betrekkingen gepleegd, ook na hun aftreden terecht voor de Hoge Raad. De opdracht tot vervolging wordt gegeven bij koninklijk besluit of bij een besluit van de Tweede Kamer'

7 See e.g. Art. 68(1) of the French Constitution and Art. 103 of the Belgian Constitution.

8 For a comparison of a number of such provisions, see Hardt \& Eliantonio 2011, p. 17-39. 
in practice. ${ }^{9}$ After all, the decision to prosecute a parliamentarian or member of the government for crimes in office may not be taken by the public prosecution service on its own motion; the order to prosecute must be given either by the government or by the Second Chamber. Hence, an element of political scrutiny is required before the prosecution of crimes in office can take place. This suggests that Article 119 has an immunity dimension which cannot be ignored in this case study.

\subsubsection{Issues}

As with the previous two case studies, this chapter attempts to comprehensively examine the constitutional phenomenon of parliamentary immunity. Following a similar structure to the chapters on the British and French immunity systems, this means that, prior to an analysis of the current positive content of the immunity provisions and their practical application, the historical foundations of parliamentary immunity in the Netherlands will also be examined. More specifically, this examination focuses on a number of issues which are of particular interest in the case of the Netherlands.

\subsubsection{Historical Reasons for Limited Parliamentary Immunity}

In how far does Dutch constitutional history explain the comparatively limited nature of immunity in the Netherlands? We have learned in the previous two case studies that parliamentary immunity in Britain and France was originally created or has evolved, if we look at the broader historical picture - in order to answer a real and specific need for the protection of parliament against, in particular, the monarch. Even though immunity has been embedded in constitutional theory both in the United Kingdom and in France, its origins were of a practical nature. Can we thus assume that the reason for a more modest immunity regime in the Netherlands was a comparative lack of conflict?

It has been argued that the reason why the Dutch chose to settle for a much more limited system of parliamentary immunity - which contents itself with nonaccountability - lies in their republican past. ${ }^{10}$ This statement may not hold true without qualification. First of all, while it is true that Dutch parliamentary immunity is, in essence, nothing more than freedom of speech in parliament, the system still contains, in the form of Article 119, remnants of inviolability which remind us of a different system that existed in the past. Second of all, it will be shown that there was no true non-accountability for members of the provincial states and the States-General during the republican period; the immunity system in its current form was adopted much later. It is therefore at least questionable whether the impact of the republican period on the development of the parliamentary immunity system really amounted to much more than laying the

$9 \quad$ R. Nehmelman proposes such a reading of Art. 119 in Nehmelman 2010. He rightly observes that Art. 119 goes largely unnoticed in the literature on parliamentary immunity in the Netherlands.

$10 \quad$ Elzinga \& De Lange 2006, p. 572. 
foundations of an egalitarian legal culture with only limited space for privileges and immunities. What is certainly owed to that Republic, however, is that the Netherlands have neither undergone an age-long struggle between monarch and parliament - as the one that had spurred the evolution of parliamentary privilege in Britain -, nor a full-fledged revolution against absolute monarchy. ${ }^{11}$ It is thus likely that the limited nature of parliamentary immunity in the Netherlands can at least partly be attributed to a lack of historical conflict between parliament and monarch. This chapter takes a closer look at the historical origins of the Dutch immunity system in light of this hypothesis.

\subsubsection{How Limited is Dutch Parliamentary Immunity in Reality?}

At first glance, parliamentary immunity in the Netherlands does not seem to be much more than basic non-accountability: Article 71 of the Dutch Constitution provides for freedom of expression in parliament. The details regarding the scope and interpretation of this provision, as well as its historical origin, will be looked at in the present chapter. It is readily apparent, however, that Article 71 provides for an immunity that is even more limited than its British counterpart. Though only vaguely defined, the latter seems to be a more encompassing institutional privilege than the freedom of speech in parliamentary debates granted by the Dutch system. It withdraws 'proceedings in Parliament' in their entirety from the ordinary course of justice and, moreover, contains remnants of a much broader immunity in the form of freedom from arrest in civil matters (although this is all but defunct today)..$^{12}$ Much more striking, still, is the difference in the degree of protection afforded to parliamentarians if one compares Article 71 of the Dutch Constitution to Article 26 of the French Constitution, which affords members of the National Assembly and the Senate the strong protection of inviolability in criminal and civil matters alike. When looking solely at Article 71, the protection which the Dutch Constitution offers members of the States-General is thus very meagre compared to the immunity systems of other states. However, as mentioned above, there might be slightly more protection: it has been proposed that Article 119 of the Dutch Constitution, which regulates criminal procedure for crimes committed in office by members of the States-General, ministers and secretaries of state, could be read as an additional layer of immunity, or transformed into one with the help of relatively minor changes in statute. ${ }^{13}$ Since Article 119 only covers crimes committed in the exercise of the office or mandate, and because prosecution under this article may be ordered by the government, it can hardly be said to constitute fully-fledged inviolability. However, depending on its interpretation and usage, it might slightly qualify our view on the Dutch immunity system. We will try to establish whether the claim that Article 119 has 'immunity potential' has any merit.

11 Although the Batavian Revolution of 1795 was certainly also directed against absolutist tendencies of the stadholders.

12 See Chapter III for a detailed discussion on the notion 'proceedings in parliament' and its practical consequences for the scope of parliamentary privilege.

13 Supra at 8 


\subsubsection{Parliamentary vs. Political Immunity}

Is the Dutch system of parliamentary immunity adequate in light of the role which parliamentarians play in modern society? Recent debates on parliamentary immunity in the Netherlands revolve around this question. Of course, a legal analysis of immunity cannot provide an exhaustive answer, since that answer will partly depend on a political definition of what we see as the content of the parliamentary mandate: are members of parliament still exercising their mandate when they disseminate their views outside parliament? Is it part of their task to participate in public debate through the media? The law does not answer these questions with certainty. However, a legal study of parliamentary immunity can demarcate the legal parameters within which this political discussion needs to take place. This chapter attempts to achieve this by clarifying the content of the law and the implications of possible modifications thereof. In particular, the proposal to expand the scope of non-accountability beyond parliamentary debates is discussed in light of the question of whether immunity is a personal right of the parliamentarian or an institutional privilege of the States-General.

\subsection{Delineation}

As in the other two states under consideration, legislative immunity does not only exist on a national level: in the Netherlands, members of regional and local assemblies also enjoy certain immunities. In particular, there is a system of nonaccountability for members of the Dutch provincial assemblies (provinciale staten) and municipal councils (gemeenteraden). ${ }^{14}$ In light of our aim to compare the immunity systems of national parliaments, an extensive discussion of the immunity rules pertaining to members of sub-national parliamentary assemblies is omitted from this chapter; the immunity rules for representative bodies on the sub-national level will only be touched upon where necessary for the discussion of the national immunity system.

On a much more limited scale than the immunity systems of France and the United Kingdom, the Dutch model of parliamentary immunity has also found its way into the constitutions of former colonies, some of which still use a comparable system. In particular, this applies to the Caribbean states which still form part of the Kingdom of the Netherlands. ${ }^{15}$ Nevertheless, because the developments in these states do not, on the contrary, have any significant impact on parliamentary

14 See Arts. 22 and 57 of the Provinces Act (Provinciewet) and Arts. 22 and 57 of the Municipalities Act (Gemeentewet). These provisions regulate the immunity of members of provincial assemblies and municipal councils as well as provincial governments (gedeputeerde staten) and the municipalities' councils of mayor and aldermen. All four provisions, mutatis mutandis, have identical wording and are very similar to Art. 71 of the Constitution. 
immunity in the Netherlands, a more detailed examination of these systems is not included in this chapter. ${ }^{16}$

\section{The History of Parliamentary Immunity in the Netherlands}

\section{1. $\quad$ The Republican Period}

The history of parliamentary immunity in the Netherlands is older than is frequently represented in the literature. Most accounts of the history of parliamentary immunity which can be found in Dutch literature begin with the constitution of the Batavian Republic of 1798. By then, however, the basic notion of parliamentary immunity was not new in the Low Countries. Evidence of instruments which resemble modern-day parliamentary immunity can already be found in the period of the Republic of the United Netherlands in Holland, then the most influential province of the republic.

Clearly, the institutional setup and tasks of the provincial states and the republican States-General of that time make it difficult to compare them to the parliament of the later kingdom. Nevertheless, a discussion of these very origins of immunity in the Netherlands is useful to test the hypothesis that the reasons for the limited nature of immunity in the Netherlands can be discovered in its republican past.

\subsubsection{The Republic of the Seven United Netherlands (1579-1795)}

The Union of Utrecht of 1579 and the Act of Abjuration (Plakkaat van Verlatinghe) of 1581 laid the foundation for the independence of the seven northern Dutch provinces from the Habsburg Empire. ${ }^{17}$ After both the King of France and the Queen of England had declined the offer to assume sovereignty over the seven provinces of Holland (Zealand, Utrecht, Gelderland, Overijssel, Friesland and the city and province of Groningen), 18 it was decided in 1588 that they should henceforth be the Republic of the Seven United Netherlands. ${ }^{19}$

This state, which the legal historian van Caenegem refers to as 'one of the most interesting legal experiments of the Old European era', ${ }^{20}$ is hard to describe in modern constitutional terms: first, the Republic cannot be categorised as either a federation or confederation. On the one hand, it was created as an alliance of

16 It should be noted that the Charter for the Kingdom, the overarching constitutional document for all states within the Kingdom of the Netherlands, does not make any mention of parliamentary immunity but leaves it to the constitutions of the individual states within the Kingdom. The Charter, though of higher rank than the Dutch constitution, is therefore of no relevance to our study.

17 Elzinga and De Lange 2006, p. 121-122.

18 The Republic included an eighth province, Drente. However, since it did not contribute to the union financially, it was not represented in the States-General of the Republic as a fullyfledged 'member'.

19 Elzinga and De Lange 2006, p. 122

$20 \quad$ Van Caenegem 1995, p. 142. 
nominally sovereign provinces which never formally relinquished their status. On the other hand, there were a number of increasingly powerful central institutions which played a significant role in the administration of the Republic. ${ }^{21}$ Moreover, although the characterisation of this union of provinces as a republic is certainly correct in a technical sense since it never had a monarchical head of state, the House of Orange did exercise a quasi-monarchical role in this republic during much of the two centuries of its existence.

It was from the ranks of this family, the descendants of William the Silent, that the 'stadholders' (stadhouders) were usually recruited. In pre-republican times, the stadholders had been provincial representatives of the foreign feudal lords to whose realm the seven provinces belonged..$^{22}$ In the Republic - where the title 'stadholder' was maintained even though the absence of a monarch or feudal lord had rendered it a paradox - they were the highest functionaries ${ }^{23}$ of the provinces and commanders of their armed forces. In principle, each province could appoint its own stadholder, but over time the position turned into a hereditary office, which members of the House of Orange exercised for the majority of the provinces and eventually for the entire Republic. However, the Republic also experienced protracted periods (1650-1672 and 1702-1742) during which most of the provinces had no stadholders. As will be shown, the political dispute between supporters and opponents of a stadholder government stood at the root of the developments of the earliest Dutch immunity provisions.

In the context of parliamentary immunity, the institutions of the republican period which are of most interest to us were the proto-parliamentary bodies of the Dutch provinces, referred to as the provincial states, and, to a much lesser extent, the States-General. As the name suggests, the provincial states were assemblies made up of representatives of the different social components (states or estates) of early modern Dutch society. ${ }^{24}$ In the case of the predominantly protestant Netherlands, only the nobility and the commons were represented, not the clergy. In republican times, the votes of the landed nobility (ridderschap) were often combined in the person of the Land's Advocate, later the Grand Pensionary, who also functioned as chairman of the states. The commons were represented by delegates of the cities; the peasantry did not send any representatives to the states but were deemed to be represented by the nobility.

Van Caenegem 1995, p. 144.

The office of stadholder in the feudal system was equivalent to that of a steward, viceroy or lieutenant. As with the latter, stadholder literally means place-holder.

23 Next to the Grand Pensionary (raadspensionaris, formerly Landsadvocaat, Land's Advocate), a high-ranking civil servant appointed and dismissed by the provincial States. The Grand Pensionary acted as chairman of the provincial states and represented the nobility in them. While this office existed in principle in all the provinces, the Grand Pensionary of Holland soon acquired a dominant position. After the office had been shaped and given much prominence by Johan van Oldenbarnevelt (1547-1619), the Grand-Pensionary mainly played an important role in foreign relations, and could, depending on the officeholder's personality, at times even take the role of 'prime minister'; See Elzinga and De Lange 2006, p. 125. 
It must not be assumed that the representatives of the cities were democratically elected in their 'constituencies' and that they were equipped with a free mandate. Rather, the delegates were chosen by an urban oligarchy, and bound by instructions from home. In pre-republican times, the states had been convened at irregular intervals at the behest of the provinces' feudal lords and had an advisory function similar to their counterparts in other European feudal states of the time, for instance, the états in early modern France. After the provinces had formed the Republic, the states themselves became the sovereign organs of each province.

The States-General, also referred to as the 'Generality', was a central assembly of delegates of the provincial states in which all provinces except Drente had one vote. ${ }^{25}$ The size of the delegation of each province was in principle undetermined; in the $17^{\text {th }}$ century it fluctuated around 30 members. ${ }^{26}$ The mandate of these members differed from that of British parliamentarians at the time or members of the modern Dutch parliament: the provincial delegates to the States-General did not enjoy an independent mandate but were mere 'spokespersons' of their home provinces. They were at all times bound by instructions they received by their mandate givers, the provincial states of which they were members, with whom they consulted continuously. ${ }^{27}$ The stadholders had access to the meetings of the States-General, but only had an advisory vote. ${ }^{28}$ Voting in the States-General usually took place by majority, but the treaty of the Union of Utrecht required unanimity for important decisions such as international alliances as well as issues of war and peace. In addition, the (very unequal) financial contributions of the various provinces were customarily fixed by a unanimous decision of the States-General.

Although the States-General were originally conceived as an irregular forum for negotiations between the provinces, they quickly developed into the Republic's 'permanent principal organ', which remained constantly in session. ${ }^{29}$ The StatesGeneral can be understood as both the (con)federal legislator and the government of the Republic, but its competences were limited to common affairs of the united provinces; the latter remained sovereign with regard to their internal affairs. However, a small part of the Republic, the so-called 'Generality Lands', was under the direct rule of the States-General. The Generality Lands were a cluster of fragmented territories and exclaves successively conquered from the Spanish during the early $17^{\text {th }}$ century, which had not received provincial status and were therefore treated as a possession of the Republic as a whole.

In light of the institutional structure of the Dutch Republic, it is not surprising that the first occurrence of parliamentary immunity of which we find evidence did not take place in the States-General but in the provincial states of the vastly

25 Elzinga and De Lange 2006, p. 125. However, in practice the States-General were dominated by the rich province of Holland, which contributed more than half of the budget of the entire republic.

$26 \quad$ Ibid. Elzinga and De Lange report that the number of delegates might have been restricted by the size of the assembly hall and the 28 available seats.

Van Caenegem 1995, p. 144.

Elzinga and De Lange 2006, p. 126.

Van Caenegem 1995, p. 144. 
dominant and most developed province, Holland. On the one hand, as opposed to other emerging parliaments, the States-General did not have to wrench their power from a potentially hostile monarch, since after the treaty of Utrecht its central position in the administration of the Republic was unchallenged. On the other hand, the States-General functioned as a forum for confederal (in the very early days of the Republic possibly even intergovernmental) deliberations between the sovereign provinces.

The participants in these deliberations did not bear a personal mandate to the States-General which would have allowed them to negotiate freely. Instead, they remained emissaries of the provincial states of which they were members and by whose instructions they were bound at all times. It is probably owing to these characteristics that non-accountability, one of the two classical components of parliamentary immunity, never had issue to emerge in the States-General of the Republic: it did not have to be asserted against a 'rival' institution at the level of the Republic, and the accountability of the delegates to their respective provincial states would have made it paradoxical to assert it against the provinces. Rudimentary forms of both components of immunity, non-accountability (freedom of speech) and inviolability (freedom from arrest) did, however, occur in the States of Holland.

\subsubsection{The Earliest Immunity Provisions in Holland}

For as far as the governing states of the provinces can be considered equivalent to modern parliaments, legislation which resembled modern parliamentary immunity can already be found in the late $16^{\text {th }}$ century. In 1588, mayor Boom of Amsterdam was arrested and held in the city of the Hague (for reasons unknown) and was therefore prevented from attending the provincial States of Holland, to which he had been summoned. Thereupon, the States issued the following acte van vrijwaring (act of guarantee).

[...] that the States understand, that the delegates of the cities, having been summoned, may not, while travelling [to the meeting of the States] or returning, nor during the time that they deliberate, for any reason concerning their cities or themselves in particular, be arrested in pursuit of the justice of the land, neither proceeded against by way of execution. ${ }^{30}$

At first glance, it appears strange that this act does not seem to cover all members of the States of Holland, but only the deputies of the cities. This may, however, not be very surprising in light of the ad hoc manner in which it was adopted by these

30 The word 'understand' should probably be read as equivalent to 'decree'. The Dutch original reads as follows:

'Dat de Staten verstaan, dat de Gedeputeerden van de steden ter dagvaart komende, in het reizen noch keeren, noch ook gedurende den tijd, dat zij compareren, uit geenerhande oorzaken, hunl. steden noch hunl. in het particulier concernerende, achtervolgende de geregtigheid van den lande, zullen mogen worden gearresteerd, noch ook tegen hunl. geprocedeerd bij wege van executie'. As quoted in Kluit 1803, p. 39-40; see also Elzinga 1990, p. 119 . 
States. While little is known about the precise circumstances, the fact that the acte van wrijwaring was a direct consequence of the imprisonment of a deputy of one city by another suggests that it was the product of a spontaneous reaction rather than a planned legislative act. It is also imaginable that the States of Holland understood their act as a reiteration in a particular case of what was already customary law. However, such a reading of the acte van vrijwaring of 1588 appears to be incorrect when considering of later developments.

How can the immunity provided by this Act be classified, applying the modern framework of reference of non-accountability and inviolability? It seems that it only protected the deputies of the cities of Holland from arrest for the time of their journeys to and from the meetings of the States of Holland and during the meetings themselves. This suggests that the aim of this act of freedom from arrest was merely to guarantee the attendance of the deputies of the cities. It appears hard to read into its text any form of non-accountability, or freedom of speech, which would render members of the States of Holland immune from judicial action for their utterances in the States. While the guarantee against the arrest of a member of the States for any reason certainly entails the prohibition of such an arrest for utterances of that member during the meeting, the limited temporal scope of vrijwaring prevents true freedom of speech. Meaningful non-accountability would per definition have to be permanent, or at least have a greater temporal scope than merely the time of the meeting plus the time required for travelling, since the anticipation of being arrested or prosecuted later could already dissuade a member from speaking his mind.

Nevertheless, it has been suggested that a certain freedom of speech was at least claimed at the time: A.J. van Emden, in his doctoral thesis of 1857, reports that Johan van Oldenbarnevelt, then Land's Advocate of Holland, ${ }^{31}$ claimed immunity (onschendbaarheid) for his utterances in the States of Holland, ${ }^{32}$ but legislation and resolutions of the States do not provide evidence for a further-reaching immunity than the act of freedom from arrest quoted above. Moreover, van Emden explains that 'freedom of discussion', like freedom from arrest, was only granted for the time during which the members deliberated. ${ }^{33}$ As argued above, such a temporal limitation acts against the assumption of freedom of speech. Moreover, absolute non-accountability would have been profoundly at odds with the terms of the deputies' mandate. Since the representatives of the free cities were also bound by instructions from home and were only provided with limited authority to negotiate, it is logical to assume that the cities had a right to hold their own deputies to account. $^{34}$ We may thus assume that the immunity adopted in 1588 by the provincial States of Holland only provided for a temporarily limited freedom from arrest and that non-accountability or freedom of speech was unknown at the time.

31 The speaker of the nobility and chairman of the provincial states (see supra at 23). In the 17th century, the office was renamed to be the Grand Pensionary.

Van Emden 1857, p. 16

Van Emden 1857, p. 17

Van Emden 1857, p. 16. Van Emden speaks of the privilege 'not to be tried but by one's natural judge'. 
This is further confirmed by developments in the 17th century, during the first 'stadholderless' period (1650-1672). This period was marked by stark opposition between supporters and opponents of stadholderless government, which gave rise to growing fears of supporters of the stadholderless status quo of future reprisals in case the political situation might change. In 1663 this led the States of Holland, in which a majority opposed the appointment of a new stadholder, to pass an acte van indemniteit (act of indemnity). This Act, quoted by van Os in his work on parliamentary immunity of 1910,35 was the first legal instrument which shows a certain similarity to modern non-accountability provisions. The States of Holland resolved:

[...] to indemnify all such members of the assembly who, in the course of time, may incur any injury to their body, goods, office or honour by reason of their proposals, discourse, advice or decisions in favour of the current government and the maintenance of freedom, and to compensate them or their heirs out of the funds of the Land. ${ }^{36}$

Van Os correctly notes that the resemblance of the act of indemnity with actual freedom of speech or non-accountability is only superficial. He argues that 'indemnity' only covers speech with a specific content: namely that which is in favour of the current stadholderless government. In effect this means, that freedom of speech is only granted to members who hold the corresponding political views the majority at the time the Act was passed. ${ }^{37}$ It may be added that a further great difference between the Act of 1663 and modern non-accountability lies in its aim and legal consequence: it does take the form of an explicit prohibition of future legal action (or in fact other, more physical forms of reprisal!) against members for their utterances in the States. Instead, the Act provides members who suffer such reprisals - or their heirs in case the suffered injury was lethal - with a claim to pecuniary compensation. Yet, the unlimited temporal scope of the Act makes it comparable to modern non-accountability instruments.

Next to the act of indemnity, van Os refers to another instance where the political conflict between supporters and opponents of a stadholderless government has brought up the question of immunity for the States of Holland. While the States opposed the appointment of a new stadholder, other institutions, in particular the Court of Holland (Hof van Holland), were strongly in favour of stadholdership. In the course of time, the Court had developed from an institution with both judicial and executive functions into a purely judicial body. However, it was feared that its

35 Van Os 1910, p. 63. This book, which will later be of interest in a discussion of the theoretical background of parliamentary immunity in the Netherlands, presents a fiery and radical plea for the complete abolition of non-accountability.

36 The Dutch original reads as follows:

'[...] om alle zulke lede der vergadering, welke in vervolg van tijd ter oorzake van de voorslagen, vertogen, raad of besluiten, tot handhaving der tegenwoordige regeering en behoudenis der vrijheid eenig nadeel in lijf, goed, ambt of eere, mogt overkomen, schadeloos de houden en hun of hunne erfgenamen vergoeding te doen uit 's lands middelen'. Van Os 1910, p. 63. 
political agenda, seeking the restoration of stadholdership, could lead to the prosecution of members of the States for their political views. ${ }^{38}$ Therefore, the delegation of the city of Amsterdam had already proposed in 1667 that the Court of Holland should not be competent to try matters relating to government, unless ordered to do so by the States. ${ }^{39}$ Further, members and former members of the States (regenten) who were to stand trial for crimes committed in the exercise of their function should have the choice between their local court, the Court of Holland and the Hoge Raad van Holland en Zeeland, the High Council of Holland and Zealand, which acted as a supreme court for these provinces. ${ }^{40}$ While these proposals were never realised, the Court of Holland eventually lost competence in 'political matters' in 1674, though an authoritative distinction between political and judicial matters was never adopted. ${ }^{41}$

Until the end of the Dutch Republic, the measures taken by the provincial States of Holland were to remain the only manifestations of parliamentary immunity in the Netherlands. It is easy to admit that the instruments quoted above are circumstantial consequences of moments of political crisis, rather than evidence of an evolving culture of parliamentarianism as has been noted in England at the same time. Apart from periods of quarrelling over the question of stadholdership, the proto-parliamentarian states of the Dutch Republic and its provinces never found themselves on one side of the divide between an increasingly assertive legislature and a potentially hostile (monarchical) executive: in the absence of a monarch, they functioned as a combination of both. In addition, the States-General did not develop an immunity system to protect its members because stricto sensu it did not have any members of its own, and with a mandate separate from membership of the provincial states.

Accordingly, parliamentary immunity did not develop into a structural component of the Republic's constitutional law but remained incidental and limited in scope. In this respect, it can be concluded that, indeed, the Dutch Republic did not lay the foundation for a tradition of parliamentary immunity similar to that of France or the United Kingdom. Whether the absence of such a tradition is sufficient to explain the limitations of parliamentary immunity in the Netherlands today must, however, be doubted.

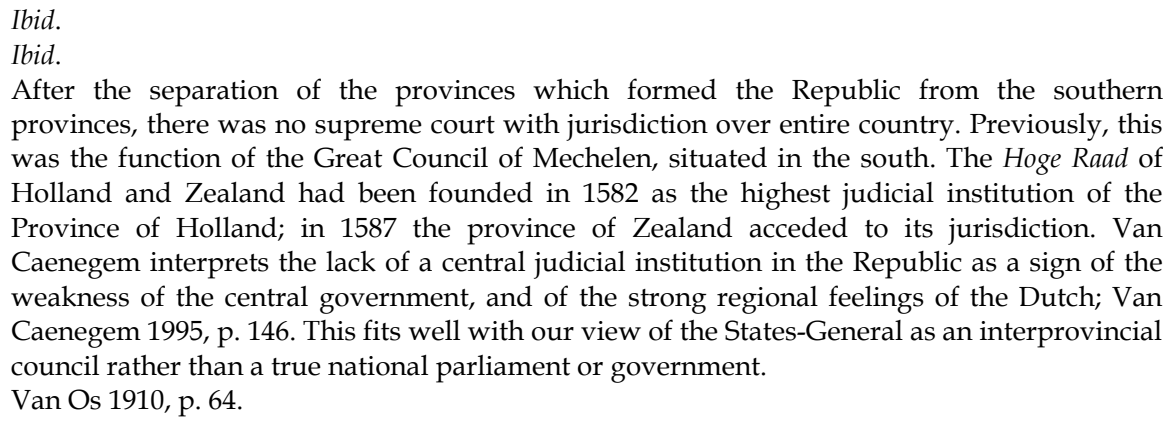
provinces, there was no supreme court with jurisdiction over entire country. Previously, this was the function of the Great Council of Mechelen, situated in the south. The Hoge Raad of Holland and Zealand had been founded in 1582 as the highest judicial institution of the Province of Holland; in 1587 the province of Zealand acceded to its jurisdiction. Van Caenegem interprets the lack of a central judicial institution in the Republic as a sign of the weakness of the central government, and of the strong regional feelings of the Dutch; Van Caenegem 1995, p. 146. This fits well with our view of the States-General as an interprovincial council rather than a true national parliament or government. Van Os 1910, p. 64. 


\subsection{The Batavian and French Period: 1795-1814}

In January 1795, the Dutch Republic, by then ruled in a quasi-monarchical style by stadholder William V, was overrun by the armies of revolutionary France and the stadholder fled to England. What followed was a period during which the Netherlands found itself in the sphere of influence of post-revolutionary France, by which it was finally annexed in 1810. The country's new position in the shadow of the mighty neighbour saw an import of many constitutional ideas, among which is the Montesquieuvian concept of the separation of powers, and parliamentary immunity. ${ }^{42}$

\subsubsection{The Batavian Republic}

Very soon, the Dutch cities, and with them the majority of the provincial states, were taken over by members of the anti-stadholder movement of the Patriots (patriotten), ${ }^{43}$ which thereby also gained a majority in the States-General. ${ }^{44}$ Following the French example, the States-General drew up a procedure for the election of a national assembly, whose task it would be to draft a constitution for the newly proclaimed Batavian Republic.

In 1796, elections were held for this national assembly, which became the first democratically elected parliament of the Netherlands. Eligible to vote were all male Dutch citizens over the age of 20 with a permanent residence and a certain income (census). For every 500 citizens of the Republic one member of an electoral college was elected. Subsequently, 30 electors elected one representative, resulting in an assembly of 126 representatives. ${ }^{45}$

Drafting a constitution for the Republic turned out to be an extremely difficult endeavour due to fierce opposition between federalists - who wanted to maintain the confederal structure of the old Dutch Republic, and unitarists - who favoured a more radical new beginning as a unitary state after the French model. The attempt to find a compromise resulted in a highly complex and lengthy document of 918 articles - commonly referred to as 'the thick book'. However, this was rejected in a referendum of August 1797.46 A new national assembly was elected the following month. This was as divided as the former, and would have had similarly dim prospects of arriving at a workable compromise. However, its work was interrupted

42 To imagine the Batavian Republic as a mere satellite state of France does, however, not do justice to this important period in Dutch constitutional development. For a comprehensive account and a partial re-evaluation of the Batavian and French period, see Van den Berg en Vis 2013, Chapters 1-4.

43 The Patriots (Patriotten) were a political movement in the latter half of the $18^{\text {th }}$ century which opposed the authoritarian rule of stadholder William V. Inspired by the recent American revolution and ideas of enlightenment, the Patriots opposed hereditary rule and promoted democracy, freedom of religion and equality. Initially, they also looked back to the Act of Abjuration sought to restore the initial confederal structure of the Republic. Elzinga and De Lange 2006, p. 130.

Ibid.

Ibid. 
by a coup d'état staged in January 1798 by radical unitarists. The remaining assembly members were forced to sign a declaration of their 'rrevocable renunciation of stadholder government, federalism, aristocracy and the absence of government' and quickly drew up a new draft constitution that was partly inspired by - and to a considerable extent literally copied from - the French Constitution of 1795 (constitution de l'an III). ${ }^{47}$ This was the Constitution for the Batavian People (Staatsregeling voor het Bataafse Volk). It was adopted on the $23^{\text {rd }}$ of April 1798 by popular referendum, for which voters had to make a declaration similar to the one cited above. ${ }^{48}$

\subsubsection{Immunity under the Constitution for the Batavian people of 1798}

As regards the structure of the state, the new constitution almost transformed the Batavian Republic into a Dutch clone of revolutionary France: the self-governing provinces and free cities which had been a central characteristic of the old Republic and a part of its constitutional identity were abolished and replaced by departments and municipalities without sovereign rights. ${ }^{49}$ For the main institutions of the national government, the constitution followed the Montesquieuvian model of the separation of powers. It deviated from the latter, however, by providing for a highest power - parliament.50 The Constitution refers to parliament simply as 'he representative body' which consisted of 'as many members as twenty thousand souls are found in the Batavian Republic'. ${ }^{51}$ Elected in a similar manner to the national assembly described above, the complete representative body would, once per year, elect 30 of its members to form the Second Chamber, while the remaining members formed the First Chamber. The government of the Batavian Republic, the executive organ (uitvoerend bewind) consisted of five members who were also elected by the representative body out of its own ranks; subsequently, one of the members of the executive organs was to be replaced each year..$^{52}$

The election system and composition of parliament and the government were very similar to the corresponding bodies in France under the Constitution of year III, which was adopted after the period of terreur. As argued in the previous chapter, that constitution can, in many respects, be seen as a reaction to the atrocities and the complete suspension of the rule of law during that period..$^{53}$ This is especially true for the almost excessively precise regulation of parliamentary immunity, which also found its way into the Batavian Constitution, whose

47 For more detail on the French influence on the content and drafting process of the Batavian Constitution, see Verhagen 1949.

$48 \quad$ Elzinga and De Lange 2006, p. 131.

49 Art. 147 of the Batavian Constitution provides that the administration of the departments and municipalities was 'subordinate and accountable to the [national] executive'.

50 The introductory article to title III of the Batavian Constitution states that 'the three main powers in a well-governed republic are: 1 . the representative highest power; 2 . the executive power; 3. the judicial power'.

Art. 51 of the Batavian Constitution.

Arts. 83, 84 and 86 of the Batavian Constitution.

The French constitution of year III is discussed in part II, section 3 of the previous chapter. 
immunity provisions are not identical to but are very clearly inspired by their French counterparts.

First, Article 71 of the Batavian Constitution provided that 'members of the representative body may never be arrested, accused or judged for what they have said or written in the exercise of their post'. ${ }^{4}$ This clearly amounted to absolute non-accountability. Depending on how broadly one interprets the phrase 'exercise of a member's post', this may have even exceeded the scope of today's Article 71, which limits non-accountability to utterances in actual parliamentary debates.

The Batavian Constitution also contained a detailed system of inviolability, laid down in Articles 71 to 82: for the duration of their mandate, members of the representative body could not be arrested, accused or put on trial, except with the approval of both chambers (so not only their own). Arrests for serious crimes were permitted flagrante delicto or within a day of the criminal act being committed, but had to be reported to the representative body without delay. An arrested member was to be released and rehabilitated immediately unless both the First Chamber, by a majority of two thirds, and the Second Chamber, by a simple majority, decided that there was reason for indictment.

Where a member was not arrested flagrante delicto, he could only be prosecuted and charged if his inviolability was lifted as a result of a petition, signed by at least three citizens and submitted to the First Chamber along with written proof of the signatories' right to vote in general elections. The First Chamber could then decide immediately that there was no reason for indictment, or resolve that a further examination was required. In the latter case, the accused had to be given the opportunity to defend himself before the two chambers, whereupon the First Chamber, and if necessary, the Second Chamber, deliberated the case in three readings and subsequently decided by secret ballot. The accused was tried by a High National Court (Hoog Nationaal Geregtshof) only if a majority of both chambers then decided that there was reason for indictment.

Whilst the complex inviolability mechanism already provided strong safeguards for parliamentarians against politically motivated prosecution, a similarly complex procedure decided on the composition of the High National Court in order to guarantee a non-biased trial. Pursuant to Article 295 of the Batavian Constitution, the High National Court was to be staffed by judges of the departmental courts. On an ad hoc basis, each of the eight departmental courts selected three of its judges by lot. Of the resulting 24 judges, eight could be rejected by both the prosecution and the defendant without justification. If reasons for the rejection of any of the remaining 16 judges were put forward by either the defendant or the accusing petitioners, a departmental court of the defendant's choice determined whether the rejection was well-founded. If this was the case, the rejected judges were replaced, again by lot, and without further appeal. Of the 16 judges who now constituted the court, four were dismissed once again by lot. One

54 The Dutch original reads as follows:

'De Leden van het Vertegenwoordigend Lichaam kunnen nimmer agterhaald, beschuldigd, of geoordeeld worden, over hetgeen zij, in de uitoefening van hunnen Post, gezegd of geschreven hebben'. 
of the remaining 12 was assigned (also by lot), the role of public prosecutor, and another that of chairman of the High National Court.

It is obvious that both the procedure for lifting parliamentary inviolability in Articles 72-82 of the Batavian Constitution, as well as the procedure by which the composition of the High National Court was determined, were extremely complex and excessively lengthy. The complicated nature of these procedures must not be understood as a consequence of previous experiences or concrete fears of the Dutch drafters of the constitution. As they did with most other parts of the constitution, the drafters imported parliamentary immunity from France, in a form which was hardly suited to - and certainly not necessitated by - the circumstances in the Netherlands. Thus, the two-tier system of non-accountability and inviolability had entered the Dutch Constitution as a 'foreign matter'. It is unsurprising, therefore, that the system did not become a lasting institution which the Dutch would have found useful to retain after the end of the French period.

However, the rapid disappearance of immunity from Dutch constitutional law was as much imposed by the French, as had been its adoption. In France, Napoleon Bonaparte had overthrown the Directorate in the coup d'état of 9 November 1799 and installed the pseudo-dictatorial government of the consulate, formalised by the Constitution of the year VIII in December 1799. At the behest of Napoleon, the Batavian Constitution of 1798 was quickly replaced in 1801.55

\subsubsection{No Immunity under the Batavian Constitutions of 1801 and 1805}

Even though the Batavian Constitution of 1798 provided in Article 304 that no amendments could be made to the constitution until the end of the year 1803, a majority of the executive body proclaimed a new draft constitution in September 1801. A vote on this draft was held in the primary assemblies (regional gatherings of citizens able to vote) but achieved a very low turnout: less than 20 per cent of eligible voters, of which a large majority rejected the draft. ${ }^{56}$ However, it was quickly decided that all votes not cast were to be counted as votes in favour, so that the new constitution could enter into force in October 1801.57

In response to the Dutch tradition of regionalism and strong identification with the old provinces, some of the overly centralistic elements of the Constitution of 1798 were mitigated. The departmental borders were redrawn to match, to some extent, the old provincial boundaries and the departments regained a degree of autonomy. ${ }^{58}$ With regard to the central government and parliament, most of the democratic elements of the old Batavian Constitution were lost, bringing the system in line with the increasingly authoritarian style of government in which Napoleon now ruled France. The Dutch Constitution of 1801 no longer referred to the representative organ, parliament, as the highest power. The new centre of gravity was clearly the executive, now consisting of 12 members, seven of whom were

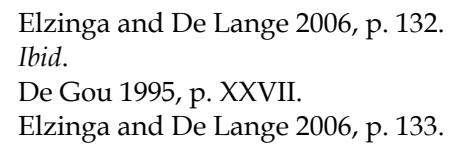


appointed by the sitting executive - the remaining five were subsequently coopted. 59

Parliament, now soberly referred to as the 'legislative body' (wetgevend lichaam) was composed of 35 members. All of them were initially appointed by the executive; the mode of subsequent elections was left to ordinary statute. ${ }^{60}$ The right of legislative initiative rested exclusively with the executive and the number of speakers in parliamentary debates was limited to 12 out of the 35 members. ${ }^{61}$

This radical cut, which limited the powers of parliament, is also evidenced by the absence of parliamentary immunity in the Constitution of 1801 . The latter was generally much more concise than its predecessor in all respects - the number of articles was reduced from 308 to 106 - and made no provision for immunity, not even basic freedom of speech. This is remarkable in light of the corresponding French Constitution of year VIII (Constitution of 13 December 1799), which maintained the two-tier system of non-accountability and inviolability (though the material scope of inviolability had been reduced). The members of the Dutch legislative body were, however, granted a certain procedural guarantee: Article 91 provided that members of the legislative body and of the government, as well as high officials of the state, could only be tried by the National Court (Nationaal Geregtshof). The members of this court were elected for life by an electoral college of five members of the legislature and five members of the government, acting by absolute majority.62 As opposed to similar procedural guarantees in later constitutions, parliamentarians were tried before this court for all criminal acts committed either in the exercise of their mandate or in the private sphere during the time in which they held the mandate. It did not, however, amount to actual inviolability, since judicial action against members of the legislature was at no time barred, as is the case, in principle, where the authorisation of parliament is required to prosecute or try one of its members. Van Os is therefore right when he claims that 'the constitution of 1801 is silent as a grave on anything that would amount to judicial non-accountability'. 63

In 1804, Napoleon took the streamlining of the Dutch vassal state one step further. He urged another constitutional reform by which the number of members of the executive was reduced to one. A new and even shorter constitution was adopted by the primary assemblies in 1805 - with a turnout of less than 5 per cent which installed a Grand Pensionary as a single-headed government. ${ }^{64}$ The office was manned by the candidate of Napoleon's choice, the previous Batavian envoy to France, Rutger Jan Schimmelpenninck. The legislative body, meanwhile, had shrunk to 19 members who were first appointed by the Grand Pensionary and who would have been later appointed by the executive bodies of the departments, had

Art. 30 of the constitution of 1801.

Arts. 49 and 55 of the constitution of 1801 .

Arts. 37 and 50 of the constitution of 1801.

Arts. 89 and 90 of the constitution of 1801.

Van Os 1910, p. 71.

Elzinga and De Lange 2006, p. 133. 
the constitution lasted longer. ${ }^{65}$ Again, the members of the legislative did not enjoy any form of parliamentary immunity beyond the right to be tried by the National Court as a forum privilegiatum for all crimes committed in the exercise of their functions as well as during the time of the mandate. ${ }^{66}$ True parliamentary immunity would only be reintroduced under the short-lived monarchical Constitution of 1806.

\subsubsection{The Kingdom of 1806 and the French Annexation}

Only one year after the last constitutional overhaul, Napoleon Bonaparte, by then 'Emperor of the French', installed his brother Louis Napoleon as King of the Netherlands, thus establishing the Kingdom of Holland. ${ }^{67}$ The decree of 5 May 1806, by which Louis Napoleon accepted kingship, as well as the Constitution of 7 August of the same year, brought relatively little change in the institutional structure of the formerly republican state. The former Grand Pensionary was appointed president for life of the legislative body, whose size was doubled to 38 members (the 19 sitting members retained their mandate, whilst the remaining 19 members were appointed by the king from a list of persons proposed by the sitting members and the provinces).$^{68}$

Interestingly, the Constitution of the Kingdom of Holland reintroduced parliamentary immunity for 'Their High Mightinesses' (Hun Hoog Mogende), as the legislative assembly was now called. The immunity was laid down in Article 73, of which the relevant parts read as follows:

The members of the assembly of Their High Mightinesses and of the Council of State are never responsible for the advice given by them.

\section{$[\ldots]$}

The members of the assembly of Their High Mightinesses, the Ministers of State, the members of the Council of State, and the High Officers of State shall at all times stand trial before the High National Court for crimes which they may have committed in the exercise of their post; as well as for crimes which they may have committed during the time for which they held their post; however, having returned to ordinary life, they shall stand trial for the latter crimes before their ordinary civil judge. ${ }^{69}$

Ibid.

Art. 80 of the constituton of 1805.

Elzinga and De Lange 2006, p. 133.

Section 4, Arts. 3 and 4 of the decree of 5 May 1806.

The Dutch original as quoted in Van Hasselt 1987, p. 163:

'De Leden der Vergadering van Hun Hoog Mogende en van den Staatsraad zijn nimmer verantwoordelijk voor de door hun uitgebragte advisen. [...]

De Leden der Vergadering van Hun Hoog Mogende, de Ministers van Staat, de Leden van den Staatsraad, en de Hooge Ambtenaren van Staat, zullen voor het Hoog Nationaal Geregtshof ten allen tijde te regt staan wegens misdrijven, welke zij in de waarneming van hunne Posten mogten hebben begaan; alsmede wegens misdrijven, welke zij mogten hebben bedreven, gedurende den tijd dat zij deze Posten bekleeden; doch tot het gewone leven terug 
In Article 73 of the Constitution of the Kingdom of Holland we consequently observe the reappearance of absolute non-accountability for the 'advice' given by members of the legislature. Article 73 did not provide any definition or requirements which an utterance of a member of the legislature needed to fulfil in order to qualify as advice. It is thus not clear, for instance, whether written words were covered and whether an utterance needed to be have occurred in the exercise of the mandate in order to fall under non-accountability. In light of judicial interpretation of the term 'advice' later in the 19 ${ }^{\text {th }}$ century (see section 2.4 .3 below), one may however speculate that both must be answered in the positive, namely, that non-accountability in the Kingdom of Holland only applied to both oral utterances and written words, in parliamentary debate.

In addition to non-accountability, Article 73 of the Constitution of 1806 contained the same procedural guarantee which had already been present in the two previous constitutions: parliamentarians and certain other office holders could only be tried before the highest judicial organ, now called the High National Court. The members of the republican National Court remained in office, but Article 72 of the new constitution provided that in case of a vacancy, the new member was to be elected by the legislature alone, from a list presented by the other members of the Court.

In 1810, after only four years as a vassal monarchy, the Netherlands finally lost even nominal independence. By imperial decree of 9 July of that year, the Kingdom of Holland was annexed by Napoleon's Empire and remained an integral part of France, ruled by a governor-general, until November 1813.

\subsection{The Kingdom of the Netherlands 1814/15-1848}

\subsection{1. 'Enlightened Absolutism' and a Weak Parliament}

After the defeat of Napoleon in the Battle of Leipzig in 1813, the northern part of the Netherlands regained their independence as a sovereign principality under William Frederik of Orange-Nassau, heir to the last stadholder William V. In spring 1814, an assembly of notables adopted a new constitution for the United Netherlands. ${ }^{70}$ It provided for a unicameral parliament, now (once again) called the States-General, whose 55 members were appointed by the states of the provinces and exercised legislative power jointly with the sovereign prince. ${ }^{71}$

Just one year later, pursuant to a decision of the Congress of Vienna, the northern Netherlands were reunited with Belgium. The incorporation of the southern provinces necessitated a few important institutional changes and,

gekeerd, zullen zij wegens laatstgemelde, voor hunnen gewonen Burgerlijken Regter worden teregt gesteld'.

$70 \quad$ Elzinga and De Lange 2006, p. 136.

71 Arts. 46, 56, 68 and 69 of the constitution of 1814 . 
formally, a new constitution. ${ }^{72}$ Even though a consultation of notables in the south resulted in a rejection of the draft text, it was declared approved on 24 August 1815: the sovereign prince, later King, reasoned that many opponents of the draft were in fact in favour and only truly opposed to freedom of religion and state-run education. However, these points were not debatable since they had been inscribed in the constitution at the demand of the great powers at the congress of Vienna. ${ }^{73}$ The sovereign prince assumed the title of King William I and despite the many changes made since, the Constitution of 1815 can be seen as the founding document of the modern Dutch state.

Van Caenegem characterises the monarchical regime under William I as 'enlightened absolutism after the $18^{\text {th }}$ century continental fashion, but tempered by the constitution and a thin parliamentary veneer' ${ }^{\prime}{ }^{74}$ Indeed, the constitution placed the King in a position in which he could pursue an authoritarian style of government: the executive was firmly in his hands, assisted by ministers who were only accountable to him and by a Council of State whose members he appointed. The 'thin parliamentary veneer' was added by the now bicameral States-General. Though officially representing the people, it was hardly representative by modern standards: the First (or upper) Chamber was composed of 40 to 60 members, appointed by the King for life 'out of those who, by evidence of their service to the State, by their birth or means, belong to the most notable of the realm' ${ }^{75}$ The 110 members of the Second Chamber were elected by the provincial states in a 'complicated system conceived to accentuate their oligarchic, undemocratic character and ensure their loyalty to the crown' ${ }^{76}$ After all, the members of the provincial states were composed of representatives of the provincial nobility, cities and the rural estate, who were themselves elected indirectly by the members of the respective estates. ${ }^{77}$

Although legislative power was exercised jointly by the King and the StatesGeneral, with the right of initiative resting with the monarch and the Second (or lower) Chamber, parliamentary opposition was thus kept weak with the help of a system of elections and royal appointment which strongly favoured supporters of the crown. In addition, the clout of the States-General vis-à-vis the King was severely limited by a decennial budget, which did not allow for parliamentary control during the budgetary term. ${ }^{78}$ indeed a new one or merely an amendment to that of 1814. See among others Kranenburg 1958, p. 46.

Cf. Elzinga and De Lange 2006, p. 137-138.

Van Caenegem 1995, p. 132.

Art. 80 of the constitution of 1815. Van Caenegem argues that the purpose of the newly introduced First Chamber was to give a political role to the nobility, which accounted for about 90 per cent of the members of the Chamber and which still enjoyed considerable social prestige in the southern provinces. Van Caenegem 1995, p. 232.

Van Caenegem 1995, p. 232.

Art. 129 of the constitution of 1815.

Art. 123 of the constitution of 1815. 
In 1830, fierce opposition by both Catholic conservatives and liberals spurred the Belgian revolution and very quickly led to the secession of Belgium from the Kingdom of the Netherlands. ${ }^{79}$ The loss of Belgium was met with relative content by the population of the northern provinces, where many appreciated 'the return to their own national cocoon' ${ }^{80}$ The King, however, was deeply disappointed. The tension created by this dichotomy of feelings between the King and his people initiated a process of general alienation between King William I and his people. This process also increasingly sparked criticism of the King's authoritarian ruling style and eventually culminated his abdication in 1840, after the Second Chamber had rejected the national budget, causing the minister of finance to resign - a first augury of ministerial accountability. ${ }^{81}$

\subsubsection{Inviolability for Crimes in Office: Indirect Freedom of Speech?}

Where the Kingdom of Holland of 1806 had granted its parliamentarians absolute non-accountability for their 'advice', no similar provision could be found in the Constitutions of 1814 and 1815. Conversely, while the Constitution of 1806 did not provide for inviolability (members were to be tried by the High National Court, but such trials did not have to be authorised by parliament), the States-General of the Principality and the Kingdom of the Netherlands had to grant explicit leave for the trial of their members and certain other classes of persons for crimes committed 'in the exercise of their functions'. Article 177 of the Constitution of 1815 provided as follows:

The members of the States-General, the heads of the departments of general administration [ministers], the members of the Council of State, the King's Commissioners in the province, stand trial before the High Council [supreme court, Hoge Raad] for all crimes, committed during the time in which they held their functions. For crimes committed in the exercise of said functions, they may never be held legally responsible unless explicit leave has been granted to that effect by the States-General. ${ }^{82}$

The Dutch original:

'De leden van de Staten-Generaal, de hoofden der depertementen van algemeen bestuur, de leden van de Raad van State, de commissarissen van de koning in de provincien, staan te regt voor den hoogen Raad, wegens alle misdrijven, gedurende den tijd hunner functien begaan. Wegens misdrijven in het uitoefenen van derzelver functien begaan, worden zij nimmer in regten betrokken, dan na dat door de vergadering der Staten-Generaal daartoe uitdrukkelijk verlof is verleend'. As reproduced in De Grondwet 1987: met verwijzingen per artikel naar overeenkomstige bepalingen van eerdere grondwetten, $12^{\text {th }}$ edition, Zwolle: Tjeenk Willink, 1994, $\mathrm{p}$. 185. Apart from the different names of some of the mentioned offices, the corresponding provision of the constitution of 1804 is identical. After the constitutional revision of 1840, Art. 177 was renumbered Art. 175. 
A close examination of this provision gives rise to several issues with regard to the scope and effect of the inviolability it creates.

First, Article 177 required that, in order to try a member of the States-General or holder of one of the mentioned offices, explicit leave had to be obtained from 'the States-General'. Did this mean that both chambers had to authorise the trial independently from each other, or possibly in joint session? Alternatively, was each chamber responsible for the inviolability of its own members, as is the case in many immunity systems today? Article 177 was silent on such procedural details and the reason for this is easily found: the wording of Article 177 of the Constitution of 1815 was left identical to that of Article 104 of the Constitution of 1814. The latter, however, provided for a unicameral States-General and therefore made no mention of the separate chambers; neither did the Napoleonic Code d'Instruction Criminelle which applied in the Netherlands between 1811 and 1838 alongside the Code Pénal, which even remained in force until 1886. Only the new Dutch Code of Criminal Procedure which entered into force in 1838 clarified the procedural aspects of Article 177 of the Constitution.

J.R. Thorbecke, the influential politician and constitutionalist who was to play a key role in preparing the grand constitutional revision of 1848, explains the details of this procedure in his commentary on the constitution. It follows from Article 318324 of the new Code of Criminal Procedure that the procurator-general at the Hoge Raad first had to apply to the Second Chamber for leave to try one of the designated persons for a crime committed in the exercise of his functions. If the Second Chamber rejected his request, the member's inviolability remained intact and no trial could take place. However, if the Second Chamber gave its permission to try the member of the States-General, this decision had to be confirmed by the First Chamber before taking effect. Both chambers had to hear the defendant member or officeholder individually before taking a decision. The procedure was to be followed in this order, regardless of which office the defendant held or of which chamber he was a member. ${ }^{83}$

In his commentary, Thorbecke also raises a second question, namely whether the second sentence of Article 177 (renumbered 175 by the time of Thorbecke's writing) equips the professional inviolability it creates with an unlimited temporal scope: If members of the States-General and office holders 'may never be held legally responsible $[\ldots]$ ', does this mean that they may be held responsible as soon as they no longer are members or office holders? Thorbecke observes that such a reading is perhaps supported by the French version of the article (which was equally authoritative before the Belgian secession), in which the word 'never' (Dutch nimmer) does not appear. ${ }^{84}$ Still, he concludes that it is probably not correct to read a temporal limitation into the inviolability provision laid down in Article 177 , 'although some doubt remains'. ${ }^{85}$ Thorbecke does not state any reasons for his

83 Cf. Thorbecke 1843, p. 180-181.

84 The French text of the second sentence of Art. 177 reads as follows:

'Pour délits commis dans l'exercice de leurs fonctions, ils ne peuvent être poursuivi qu'après que les états-généraux ont autorisé la poursuite'.

85 Thorbecke 1843, p. 188. 
conclusion, but it may be supported by the fact that the factor which triggers inviolability is not the quality of being a member of parliament or holding a high office of state per se but the presence of a material link between that quality and the alleged criminal act at the time it is committed. This link persists, regardless of whether or not the person in question still holds this function at the time of the trial.

In addition, while in the case of parliamentarians it could be argued that inviolability, even if limited to the duration of the mandate, at least serves the function of guaranteeing the member's attendance of parliamentary meetings, this is not true for other office holders. The latter can be removed from their post by the government at will, which renders inviolability futile as a measure of protection against the executive. Hence, it appears logical to follow Thorbecke's conclusion and assume that inviolability was not limited in time.

A third and perhaps the most interesting issue in the context of Article 177 is the question of how 'crimes committed in the exercise of their functions' were exactly defined. After all, a member was only protected by inviolability - that is, he could only be tried with the consent of the chambers - if the alleged criminal act in question had indeed been committed in the exercise of his functions. As for criminal acts committed independently of those functions, Article 177 only provided for the old procedural guarantee of a criminal trial in first instance before the highest court, which could, however, proceed without the authorisation of the States-General.86 Whereas the Napoleonic Code Pénal contained several norms against crimes specifically associated with the professional life of public officeholders or civil servants (such as bribery), matters become more difficult in case of criminal acts which can be committed both 'privately' and in the exercise of a public office or parliamentary mandate.

This problem was acknowledged by Thorbecke in his commentary on the constitution, where he realises that '[1]egislation on the delicta propria or crimes in office of members of the States-General is still a wasteland' ${ }^{87} \mathrm{He}$ does not offer a solution to this problem, but sees that that it is of particular relevance with regard to potentially criminal utterances of parliamentarians: '[d]id the member of the StatesGeneral who, speaking in the Chamber is deemed to have insulted a minister [...], commit a crime in the exercise of his mandate?'. ${ }^{88}$ The only argument which speaks against a positive answer to that question is that insults, by their very nature, cannot constitute an element of proper parliamentary debate and therefore fall outside a very narrow understanding of the functions of a member of the States-General. ${ }^{89}$

86 It should be noted that a first-trial before the Hoge Raad did not necessarily work in favour of the defendant, since there was no possibility of appeal against a judgment of the highest court.

87 Thorbecke 1843, p. 188.

$88 \quad$ Ibid.

89 This argument is not as far-fetched as it may seem. On the one hand, it is imaginable that utterances of certain content are exempt from the protection of parliamentary immunity. The German constitution, for instance, provides for absolute non-accountability, but with the exception of defamatory insults (Art. 46 of the Basic Law). On the other hand, a similar argument was used in the Netherlands in the latter half of the 19th century in order to circumvent non-accountability, which by then rendered parliamentarians and members of 
Such a narrow interpretation is unlikely, and was so even in the early $19^{\text {th }}$ century, precisely because Article 177 did not even purport to guarantee absolute freedom of speech, but only required a political judgment of the States-General to precede judicial trial, wherever an alleged criminal act was connected to the duties of a member of the States-General or officeholder. There is thus reason to assume that crimes committed in the form of utterances in parliament were covered by inviolability under the Constitutions of 1814 and 1815.

This view conflicts with some accounts of the history of parliamentary immunity found in the literature. These accounts argue that freedom of speech in parliament did not exist under the Constitutions of 1814 and 1815. While it had still been present in the Constitution of 1806, it had then been bartered for inviolability. Consequently, it is argued that, under the Constitutions of 1814 and 1815, members of the States-General could be held liable unconditionally for their utterances in the States-General. ${ }^{90}$ However, in light of the considerations above, it may be doubted whether this picture is accurate. This doubt is confirmed by several other accounts which offer a different assessment, acknowledging that the inviolability laid down in Article 177 of the Constitutions of 1814 and 15 also protected members from trial for criminal utterances which today are protected by non-accountability. ${ }^{91}$

Certainly, it must not be forgotten that the legal nature of non-accountability differs from that of inviolability: the former withdraws utterances in parliament from the field of application of the criminal law, while the latter does not decriminalise them but merely constitutes a procedural bar which inhibits the trial of members for such utterances. Nevertheless, provided that the inviolability of a member is not lifted, the practical effect is the same. One prominent Dutch constitutionalist of the $19^{\text {th }}$ century, J.T. Buijs, has even made the remarkable observation that the limited inviolability regime of the Constitutions of 1814 and 1815 offered a higher level of protection than the absolute inviolability which took its place in 1848. Comparing the two systems with regard to their effect on the independence of parliament, he wrote:

Has the independence of the people's representative really increased after this reversion [from inviolability to non-accountability]? It does not seem so. True, in the past he was subject to the general law, also for what he said during the meeting. But since he could not be prosecuted for any crime committed in the exercise of his functions without explicit leave by the States-General, the latter were able to factually withdraw him from the general law. The guarantee which was granted thus entailed, at least to a certain extent, the other guarantee which was not granted. ${ }^{92}$

This leads to the perhaps surprising conclusion that despite the absence of explicit non-accountability, the Constitutions of 1814 and 1815 provided for a considerable degree of protection which also covered criminalised speech in parliament, along

provincial and municipal assemblies immune for their 'advice'. This term, it was claimed, did not cover insults and strong language.

Cf. Van Os 1910, p. 71; Akkermans 1987, p. 655.

Cf. Van Emden 1857, p. 28-29.

Buijs 1883-1888, p. 537-538. 
with other offences committed in the exercise of the mandate. It should be noted, however, that this protection could be lifted by a majority in both chambers and was therefore not absolute. Thorbecke, pleading for non-accountability instead of inviolability, also observed that 'even if [a member] can count on the majority of the States-General, the request for leave to put him on trial is already the beginning of a criminal charge, from which he is saved, except that it may seem that he owes his being saved exclusively to the favour of his fellow members' ${ }^{93}$

\subsection{Towards the Constitution of 1848}

In 1840, the year of the abdication of William I, a general constitutional revision introduced criminal liability of ministers for breach of the constitution and statute. This was laid down in the newly introduced Article 75 of the Constitution, which provided as follows:

The heads of the ministerial departments are responsible for all acts, performed by them personally or to whose accomplishment or execution they have contributed, through which the constitution or statutes may have been violated or disobeyed.

Nevertheless, for the time being, the criminal violation of the constitution or statutes by ministers remained within the scope of inviolability pursuant to the former Article 177 of the Constitution, which had now been renumbered Article 175.

Moreover, the constitutional revision of 1840 reduced the budgetary term from 10 to two years and adapted the size of the States-General to the reduced population size after the Belgian secession. However, the main lines of the constitutional system in which the balance of power tilted strongly towards the King - through the lack of political ministerial accountability to parliament and a profoundly undemocratic election system - remained unchanged for almost another decade.

After a series of proposed constitutional amendments after 1840 had failed for various reasons, the revolutionary mood which led to upheaval in several states on the European continent in 1848 caused William II to agree with an incisive and fundamental constitutional overhaul. ${ }^{94}$ The King appointed a committee under the leadership of J.R. Thorbecke to draft a set of far-reaching amendments, which were finally adopted on 11 October 1848. Crucially, Thorbecke had already been involved in the preparation of earlier proposals for constitutional revision; in particular, he had led the committee of nine members of the Second Chamber commonly referred to as 'the Nine Men' (Dutch: de negenmannen) which proposed a series of farreaching amendments in $1844 .{ }^{95}$

Probably the most important novelty brought about by the amendment of 1848 was, finally, the introduction of political ministerial accountability. Article 53

Thorbecke 1841, p. 237.

Elzinga and De Lange 2006, p. 142.

These proposals were largely based on Thorbecke's own ideas, presented in his book (Thorbecke 1840). However, in spring 1845, the Second Chamber decided not to adopt the proposal of 'the nine men'. 
contained the formula according to which 'the King is inviolable; the ministers are responsible' - which established one of the main roots of the parliamentary system by which the Netherlands is still governed today. ${ }^{96}$ Further, direct elections (under a census) were introduced for municipal councils, provincial states and the Second Chamber of the States-General. The competences of the latter were also strengthened by the right of enquiry and a further shortening of the budgetary period to one year. Finally, the members of the First Chamber, previously appointed by the monarch at will, were now elected by the provincial states for a term of nine years, a third of them to be replaced every three years.

\subsubsection{The Abolition of Inviolability}

With the general overhaul of the constitutional system, the system of parliamentary immunity was fundamentally changed from limited inviolability to nonaccountability.

The loss of inviolability owed to an amendment of the provision which regulated the trial of members of the States-General, ministers and other high officeholders for crimes in office. Prior to 1848, Article 177 (later Article 175) of the Constitution had required that the procurator-general obtained the explicit authorisation of both chambers of the States-General before such trials could be conducted before the Hoge Raad. While the new constitution did not abolish this provision completely, Article 159 now provided the following:

\footnotetext{
The members of the States-General, the heads of the ministerial departments, the governors-general or the high officeholders endowed with the same power under another name in the colonies or possessions of the Kingdom in other parts of the world, the members of the Council of State and the Commissioners of the King in the provinces stand trial before the High Council Supreme Court [Hoge Raad] for crimes committed in office [ambtsmisdrijuen], prosecuted either by the King or by the Second Chamber. ${ }^{97}$
}

This provision differed from its predecessors in various respects. First, the Hoge Raad was no longer designated as the trial court for all criminal acts committed by the mentioned persons as had previously been the case, but only for crimes

96 It should be noted, in this respect, that the constitution of 1848 did not introduce the parliamentary system of government expressis verbis. While Art. 89 of the constitution of 1848 obliged ministers to provide either chamber of the States-General with any information they might request, the confidence principle or the possibility of a motion of censure was never laid down in any constitutional provision but exists as a constitutional convention.

The Dutch original:

'De leden der Staten-Generaal, de hoofden der ministeriele departementen, de gouverneursgeneraal of de hooge ambtenaren onder een andere naam met gelijke magt bekleed in de kolonien of bezittingen des Rijks in andere werelddeelen, de leden van den Raad van State en de commissarissen des Konings in de provincien staan, wegens ambtsmisdrijven, ter vervolging hetzij van Koningswege, hetzij vanwege de Tweede Kamer, te regt voor den Hoogen Raad'. 
committed in office. ${ }^{98}$ The Dutch original now referred to the latter with the word ambtsmisdrijven, whereas Article 177 (now Article 175) of the previous constitution had still used the cumbersome formula of 'crimes committed in the exercise of their functions'. Most importantly, however, the 'immunity value' of Article 159 decreased significantly compared to that of its predecessor, as both the Second Chamber and the King (read: the government) could now unilaterally decide to put a parliamentarian or officeholder on trial for crimes in office. This had previously required the assent of the States-General in separate decisions of the chambers, both of which had to give the defendant the opportunity to be heard. Crucially, the Constitutions of 1814 and 1815 had also not allowed the executive to prosecute members of parliament and high officeholders for crimes committed in office without leave of the States-General, which now became possible pursuant to the last sentence of Article 159 of the Constitution of 1848.

For members of the States-General, this change brought an end to inviolability as a means of protection against the possibility of politically motivated prosecution instigated by the government, because leave of the States-General was no longer required for their prosecution. It could now be ordered either by the chamber or directly by the government.

The criminal responsibility of ministers for violation of the constitution or of statute, which had been regulated in a separate constitutional provision (Article 75) since the revision of 1840 , also fell within the scope of Article 159. The details of criminal procedure in case of the prosecution of ministers were left to ordinary statute, ${ }^{99}$ which led to the adoption of the Criminal Ministerial Accountability Act in 1855 (wet op de strafrechtelijke ministeriële verantwoordelijkheid).

With several amendments, this Act is still in force today. According to its provisions, the Second Chamber may order the procurator-general at the Supreme Court to prosecute a minister. However, it may only do so upon a request of at least five of its members and after an in-depth examination of the allegations by a parliamentary enquiry committee. The order may not be given if the enquiry committee comes to the conclusion that there is no reason for indictment, or if no decision has been taken within three months after the initial request. Before the Second Chamber orders the procurator-general to begin the prosecution of the minister before the Supreme Court, it 'tests the alleged acts against the law, reason, morality and the interest of the state'. ${ }^{100}$ Alternatively, the government may order the prosecution without a prior committee enquiry or if the enquiry period of three months has lapsed without result, but not if the committee has decided that there is

98 However, the abolition of the forum privilegiatum for ordinary criminal acts only acquired practical effect when the States-General made the necessary changes to ordinary legislation in 1884. Therefore, it was still possible in 1880 that a member of the First Chamber was tried in first instance by the Hoge Raad for an ordinary crime. This was the only instance to this day in which a member of the States-General stood trial before Dutch Supreme Court in first instance. See Van Raalte 1971, p. 179.

$99 \quad$ See Art. 73(2) of the constitution of 1848.

$100 \quad$ Art. 18(1) of the Criminal Ministerial Accountability Act in 1855. 
no reason to indict the minister. Finally, the procurator-general is obliged to follow the order by the Second Chamber or the Government to prosecute the minister.

\subsubsection{Inviolability Traded for Non-accountability}

Instead of inviolability, the Constitution of 1848 introduced absolute nonaccountability. At first, the new immunity, laid down in Article 92 of the Constitution, only covered the members of the chambers, and not the ministers and others:

The members of the Chambers may not be judicially prosecuted for the advice given by them in the assembly. ${ }^{101}$

With the introduction of this provision and the abolition of inviolability, the constitutional legislator of 1848 had created the immunity system to which the Netherlands, in principle, still adheres today, although the personal scope of nonaccountability has later been broadened to cover others speaking in parliament, and the wording of the constitutional provision has changed slightly.

What, however, were the reasons which led the constitutional committee around Thorbecke to trade limited inviolability - which, as we have argued, could with relatively little effort be construed so as to cover criminalised speech in parliament - for absolute non-accountability? This development stands in contrast to all incisive changes and development leaps we have observed in the immunity systems of the United Kingdom and France, where they were always linked to political crisis or (the fear of) imminent threats to parliament. While 1848 was certainly a year of widespread political upheaval and general insecurity, the members of the Dutch States-General were under no concrete or circumstantial pressure to avail themselves of freedom of parliamentary speech. The reason for which the Constitution of 1848 traded inviolability for non-accountability must thus be found elsewhere.

It is likely that the main cause for this trade was the urge to adapt the immunity system to the changed relationship between parliament and the monarch. With the Constitution of 1848, the power balance between the States-General and the executive started to tilt towards the former, and in the general wish to modernise the system, in line with 'most newer constitutions'. ${ }^{102}$ In a much more assertive parliament, now equipped with the right of enquiry and the power to question and critically comment on government policy, it was only logical that members should enjoy freedom of speech. Conversely, inviolability as a means of protection against a government that was increasingly subject to parliamentary scrutiny was deemed less useful. This view is supported by the fact that the inviolability provided by the constitution prior to 1848 had led a non-contentious,

101 The Dutch original:

'De leden der Kamers zijn niet geregtelijk vervolgbaar wegens de advijzen, door hun in de vergadering uitgebragt'.

102 Thorbecke 1841, p. 238. 
dormant existence, which led Buijs to conclude that the privilege it had created had lost its raison d'être, since: 'the times are long gone that governments tried to maintain themselves by interfering with the freedom of deputies and resorted to unjustified judicial prosecution to prevent them from fulfilling their mandate'. ${ }^{103}$

In addition, Thorbecke's personal preference for a Westminster-oriented immunity system and his dislike for the vagueness of the Dutch inviolability model may have had a decisive impact. With regard to crimes committed in office by members of the government, he had already voiced criticism on an inviolability system which was at all times conditional on the political will of the majority, as well as the expertise and political sensitivity of the procurator-general whose task it was to launch criminal proceedings under Article 177 (now Article 175) of the Constitution. In Thorbecke's opinion, criminal law was generally not a good instrument in political matters, which notoriously escaped neat legal definition and categorisation and required the interference of the procurator-general:

'Take the letter of the constitution. Remind yourself of how the simplest and clearest articles are subject to argument. What a weak safeguard against criminal liability for the highest and most dangerous injustice in the state, if it always depends on the way in which the procurator-general understands the law!'.104 [emphasis original]

Rather, he argued, matters of political sensitivity require an authority 'with a much greater freedom [than that of the criminal judge], a freedom which borders on the legislative power itself'. ${ }^{105}$

However, it appears that this did not make Thorbecke a proponent of absolute and unconditional non-accountability. The proposal for constitutional amendments which the 'Nine Men' drafted under his aegis in 1844 still contained a nonaccountability provision that rendered members of the States-General immune from criminal proceedings for their 'advice' in parliament, 'unless in cases specified by statute'.106 According to the explanatory memorandum, this exception was inserted for fear that the chambers' Rules of Procedure could perhaps not offer sufficient safeguards against every possibility of abuse. ${ }^{107}$ Interestingly, when the proposal of the 'Nine Men' was discussed in committee, it was rejected as unnecessary, as experience had shown that no constitutional protection was necessary to safeguard free speech in parliament. ${ }^{108}$ Nevertheless, non-accountability was again included in the successful constitutional revision of 1848 , and accepted by both chambers entirely without debate.

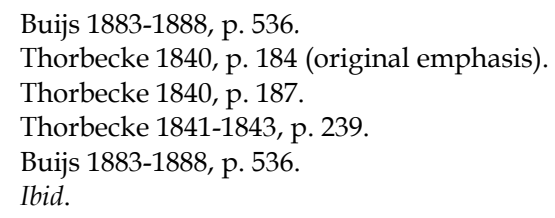




\subsubsection{The Disputed Scope of Non-accountability}

Buijs identified two essential characteristics of non-accountability as laid down in Article 92 of the Constitution of 1848. First, he argued, the new immunity was not a personal privilege but one that was tied to the place and time of the parliamentary meeting. Accordingly, its aim was not to protect the member of parliament as a person, but to 'keep the criminal judge out of the States-General', and to put the Rules of Procedure of the chambers in place instead. Second, the material purpose of Article 92 was to relieve the parliamentarian of all criminal liability for anything he might say in the chamber. ${ }^{109}$ Even though these characteristics were formulated clearly in the explanatory memorandum, they did not appear unequivocally from the wording of Article 92. In particular, the word 'advice' proved problematic.

During the second half of the $19^{\text {th }}$ century, a series of judicial rulings showed that the wording of the non-accountability provision was susceptible to an extremely narrow interpretation by the courts. ${ }^{110}$ These rulings concerned Article 47 of the Municipalities Act (Gemeentewet), which granted members of municipal councils non-accountability for their 'vote or opinion'. While 'opinion' might even seem to be a more comprehensive term than 'advice' and in any event does not suggest a more restrictive interpretation, the Hoge Raad read it as a 'statement about a pending proposal'. After all, the Court argued, the aim of Article 47 of the Municipalities Act was 'to safeguard the independence and freedom of deliberations', so that 'the non-accountability of members of the council cannot reach further than such utterances as were part of their vote or opinion, expressed during the meeting about an object being debated there'. ${ }^{111}$ In particular, both the Hoge Raad and lower courts repeatedly repudiated the opinion that municipal nonaccountability covered insults or defamatory statements. Buijs reports another case in which the Advocate General at the Hoge Raad opined that it would be 'contrary to any notion of social order if membership of a representative council would provide a carte blanche to insult and defame other members with impunity'. The Court concurred with this Opinion. ${ }^{112}$ The precise scope of the non-accountability of members of the States-General ex Article 92 of the Constitution of 1848 was never litigated, but the vehemence with which the courts opposed the reading of Article 47 of the Municipalities Act as providing for absolute non-accountability for utterances in council suggests that such a reading would have been rejected even more vigorously for the constitutional provision - after all, while an insult may very well express an 'opinion', it hardly constitutes 'advice' in a narrow sense.

Nevertheless, in light of the aim which the constitutional legislator pursued, Buijs was certainly correct in his radical dismissal of the extremely restrictive interpretation given to non-accountability by the courts: 'a more complete misconception of any constitutional provision [...] is hardly thinkable' ${ }^{113}$ Indeed,

Ibid.

Elzinga 1986, p. 217, note 12; see also Buijs 1883-1888, p. 540-545.

HR 30 July 1861, Weekblad van het Recht No. 2297.

HR 1 March 1854, as quoted in Buijs 1883-1888, p. 543.

Buijs 1883-1888, p. 539. 
the reading which the courts gave to Article 92 of the Constitution of 1848 and to the non-accountability provisions for provincial and municipal assemblies missed the point and purpose of non-accountability, because it meant that judges made the decision as to which utterances in parliament deserved protection. The consequences of this discretion in cases involving non-accountability for national parliamentarians have never been tested in case law and indeed it is not beyond doubt that the Supreme Court would have assumed the same discretion in such high-profile cases. However, if it had done so, this would have had the paradoxical consequence that non-accountability only protected such utterances as were - in the eyes of the Court - manifestly not punishable in the first place. This strongly reminds us of the United Kingdom, where the differentiation between the power of Parliament to determine the content of its privileges and the power of the courts to define their boundaries has led to friction and conflict.

The Dutch constitutional legislator took the case law with regard to the nonaccountability of municipal councils explicitly into account in the constitutional revision of 1887. The explanatory memorandum to the amendment of Article 92 proposed by the government states that:

[a]ccording to case law of the Hoge Raad concerning article 47 of the Municipalities Act, article 92 of the constitution does not provide sufficient safeguards against the prosecution of members of the States-General for what they have said in the meeting or submitted in writing. The wording must therefore be clarified. ${ }^{114}$

As some members of the Second Chamber wished to maintain the term 'advice' for fear that a broadening of non-accountability would lead to chaos if members could with impunity say anything they liked even when not given the floor, the government argued that the disciplinary powers of the chambers would suffice to maintain order. ${ }^{115}$ Accordingly, what had become Article 97 after a renumbering in the revision of 1887 now provided for non-accountability in the following terms:

The members of the States-General may not be judicially prosecuted for what they have said in the assembly or submitted to it in writing. ${ }^{116}$

The phrase 'what they have said in the assembly' no longer left any room for a restrictive interpretation by the courts. With this wording, the non-accountability of Dutch parliamentarians had finally become truly absolute.

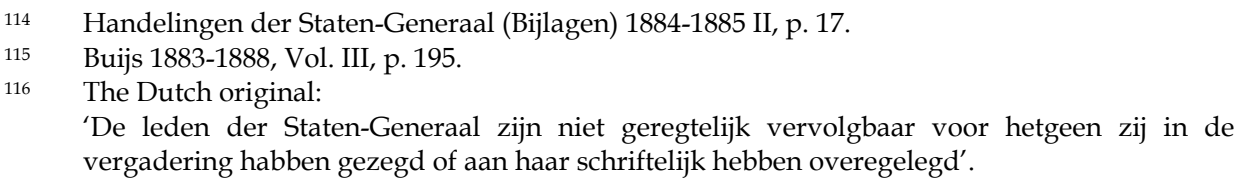




\title{
2.5. More Non-accountability and Less Inviolability: A Negative Correlation?
}

In exchange for this broadening of the material scope of non-accountability, the scope of the provision which governed criminal proceedings in cases of crimes committed in office - which can be understood as a trace or remnant of the actual inviolability that existed earlier - has been further limited in the constitutional revision of 1887. Two small additions were made to the text of Article 159 of the Constitution of 1848, now renumbered Article 164. This provision was now also merged with former Article 160, pursuant to which the special procedure for crimes in office could be applied to offices other than those mentioned. Article 164 (additions of 1887 in italics) now reads as follows:

\begin{abstract}
The members of the States-General, the heads of the ministerial departments, the governors-general and the high officeholders endowed with the same power under another name in the colonies or possessions of the Kingdom in other parts of the world, the members of the Council of State and the Commissioners of the King in the provinces stand trial, also after having left office, before the High Council for crimes committed in office in these capacities, prosecuted either by the King or by the Second Chamber.
\end{abstract}

Statute may determine that other officeholders and members of high colleges stand trial before the High Council for crimes committed in office. ${ }^{117}$

The incorporation of the former Article 160 is of no further relevance with regard to parliamentary immunity. The addition of the phrase 'also after having left office' merely made explicit the reading which Thorbecke had already accepted as the most logical one 40 years earlier, namely that a member or officeholder would stand trial before the Hoge Raad, regardless of whether he still held his mandate or office at the time of the trial.

More interestingly, the addition 'committed in these capacities' can be read as a real material limitation. This is because the persons to whom Article 164 applied may well have held other public offices simultaneously to those specifically mentioned there, as was frequently the case in the $19^{\text {th }}$ century. Under Article 159 of the Constitution of 1848, crimes committed in the exercise of another office would have triggered the legal consequence of standing trial in first and last instance before the Hoge Raad. This possibility was now explicitly ruled out, to the effect that

117 Dutch original:

'De leden der Staten-Generaal, de hoofden der ministeriele departementen, de gouverneursgeneraal of de hooge ambtenaren onder een andere naam met gelijke magt bekleed in de koloniën of bezittingen des Rijks in andere werelddeelen, de leden van den Raad van State en de commissarissen des Konings in de provincien staan, wegens ambtsmisdrijven in die betrekkingen gepleegd, ook na hunne aftreding ter vervolging hetzij van 's Konings wege, hetzij vanwege de Tweede Kamer, te regt voor den Hoogen Raad.

De wet kan bepalen, dat nog andere ambtenaren en leden van hooge collegien wegens ambtsmisdrijven voor den Hoogen Raad te regt staan'. [emphasis added] 
the required material link had to exist between the alleged criminal act and one of the offices specifically mentioned in Article 164. ${ }^{118}$

Certainly, these changes were hardly spectacular and, seen individually, rather minuscule. However, they illustrate once more the negative correlation which seems to have existed between non-accountability and what we may call 'rest-inviolability' throughout the development of the immunity regime during the $19^{\text {th }}$ century. Whenever one of the two was newly introduced to the constitution or its scope increased, the other one disappeared or was substantially reduced in scope. For the Dutch immunity regime as a whole, this has resulted in the virtual disappearance of inviolability. This is thought-provoking from a comparative perspective - in particular if we remind ourselves that the French tradition of parliamentary immunity tends to justify the co-existence of non-accountability and inviolability by presenting them as complementary sides of the same coin, none of which provides parliament with adequate protection without the other.

In addition, the negative correlation between non-accountability and the provisions governing the special criminal procedure for high office holders during much of the Netherlands' constitutional history may constitute a historical argument against the interpretation of the current Article 119 of the Constitution as a form of inviolability. We will return to this at a later point.

\subsection{Developments during the $20^{\text {th }}$ Century}

At several instances during the early $20^{\text {th }}$ century, the personal scope of nonaccountability was significantly broadened. First, the constitutional revision of 1922, in which the non-accountability provision was renumbered Article 98, extended non-accountability to the ministers, commissioners of the King, ${ }^{119}$ and certain civil servants appointed by the ministers. ${ }^{120}$ The constitutional revision of 1948 added the secretaries of state. ${ }^{121}$ The main argument brought forward in support of these amendments was that an immunity limited to members of the States-General would discriminate between ministers who were members and thus enjoyed nonaccountability and ministers (and civil servants) who were not at the same time members of one of the chambers. ${ }^{122}$ Before the constitutional revision of 1938, the parliamentary mandate was not required for, but was compatible with ministerial office. After the amendment of 1938, the two were mutually exclusive, while ministers and civil servants continued to take part in the debates of the StatesGeneral. Given that, at the same time, there was no separate immunity regime for members of the government other than the special procedure for crimes in office which no longer amounted to actual immunity, it was thus completely logical to extend parliamentary immunity to ministers and high civil servants. However, the

118 See on this Buijs 1883-1888, Vol. III, p. 113-114.

119 Civil servants appointed by the king whose task it was to support the ministers in debates on government bills in the States-General (constitution of 1922, Art. 111). Art. 95 of the constitution of 1922.

Art. 79 of the constitution of 1948. The former Art. 98 was renumbered Art. 100.

Elzinga 1986, p. 217. 
extension of non-accountability to members of the government and their support staff marks a clear departure from the traditional idea of parliamentary immunity as a means of protecting parliamentarians against a potentially hostile executive. Rather, the emphasis was now on protecting parliamentary debate as such, independently of the capacity in which a person took part in it. Materially, the Dutch immunity system was thereby brought in line with that derived from Article 9 of the English Bill of Rights 1689, which protects 'debates and proceedings in Parliament' rather than the member as a person.

During the 1930s, the material scope of (national) parliamentary nonaccountability was clarified by case law of the appeal courts of Amsterdam and Arnhem. ${ }^{123}$ Confronted with this question for the first time on a national level, the courts ruled that the prohibition of 'judicial prosecution' (niet gerechtelijk vervolgbaar) for utterances in parliament did not only bar criminal prosecution but all judicial proceedings, including civil lawsuits. It has been argued that this interpretation of Article 98 of the Constitution of 1922 constituted a further broadening of nonaccountability, since there had been doubt as to whether civil liability was indeed excluded. ${ }^{124}$ However, it is likely that the reading given to Article 98 by the courts was congruent with the initial intentions of the constitutional legislator - and thus did not actually add a new facet to the immunity: the possibility of civil liability would have defied the purpose of non-accountability.

During the first two decades of the $20^{\text {th }}$ century, scholarly debate about parliamentary immunity still revolved almost exclusively around the question whether it was justifiable to grant members of the States-General the freedom to say or write whatever they like. Mostly, this question was approached with a moralistic undertone. Often, the arguments against non-accountability were based on the thought that anything which amounted to criminal insult or defamation could not possibly be in the interest of constructive legislative debate and therefore did not deserve protection. ${ }^{125}$

In the 1930s, however, the Dutch legislature was increasingly confronted with political movements on the extreme left and the extreme right of the political spectrum. In particular, parliamentarians affiliated with the National Socialist Movement (Nationaal-Socialistische Beweging, NSB) used their non-accountability not only to insult and defame their political enemies in and outside parliament and to taunt the targets of their racist agenda, but also to advocate the Nazi 'revolution' and the overthrow of the constitutional order. ${ }^{126}$ This presented the constitutional legislator with a new dilemma: how to proceed with parliamentarians who swear

123 Hof Amsterdam, 10 January 1934, NJ 1934, 1453; Hof Arnhem, 18 March 1937, NJ 1937, 367.

$124 \quad$ Elzinga 1986, p. 217.

125 See among others the rather polemic analysis of parliamentary immunity of Van Os 1910 and, in particular, the preface to his book by H. Krabbe. However, their conservative arguments were rebutted by others who first defended a broad reading of the term 'advice' in the constitution of 1848 and later argued in favour of the new wording in which inviolability was cast by the constitution of 1887: See Buijs 1883-1888 and Baron de Vos van Steenwijk 1927, p. 103-125.

126 Wijman 1995, p. 7-8. 
allegiance to the constitution and take cover behind constitutional safeguards aimed at the preservation of the democratic order, but who use this protection to sabotage and agitate against that very order?

In 1934, the leader of the liberal party group in the Second Chamber, Knottenbelt, aware of the difficulty of amending of the constitution, proposed to introduce a provision to the criminal code. By virtue of this, a member of the StatesGeneral could be deprived of his active and passive voting right (which would result in the loss of the parliamentary mandate of a sitting member) if he violated, for example by seditious utterances in or outside parliament, his oath of allegiance to the constitution. Knottenbelt urged the government to propose legislation to that effect. ${ }^{127}$

The government reacted hesitantly to Knottenbelt's proposal but established a committee, referred to as the 'Koolen committee' after its chairman, assigned with the task to investigate the necessity and expediency of 'statutory and other measures relating to the membership of representative bodies of persons whose efforts are evidently directed at changing the institutions of the state by way of unlawful means'. ${ }^{128}$ The committee found two possible measures, both of which would, in its view, not have required an amendment of the constitution.

The first measure it recommended was the introduction of a possibility to sanction members of any representative body on a national, provincial or municipal level who in their [official] activities as such or by making use of the power, opportunity or means derived from their membership, express their intention to change the existing legal order by using or facilitating unlawful means'. ${ }^{129}$ The sanction envisaged by the Koolen committee was forfeiture of membership of the representative body in question, to be declared by the department of the Council of State (a body with both advisory and judicial functions) which was assigned to deal with the resolution of disputes between organs of state. ${ }^{130}$

The second recommendation of the Koolen committee aimed at an amendment of the criminal code which would introduce the loss of active and passive voting rights as a mandatory additional punishment for certain crimes such as sedition and lèse-majesté. ${ }^{131}$ This punishment would have automatically entailed the forfeiture of the mandate of a sitting member of any representative body. According to the critics of the proposal, this proposed sanction gave rise to serious constitutional concerns, as it would have led to the underrepresentation of the revolutionary-minded electorate of the member whose mandate was lost. ${ }^{132}$

Neither recommendation of the Koolen committee was accepted or processed into a legislative proposal by the government, which reasoned that a satisfactory

127 Handelingen van de Staten-Generaal 1933-1934 II, Voorlopig verslag der Rijksbegroting, Bijlage A, p. 24-25.

128 The Koolen committee, officially the 'Committee on the membership of representative bodies' was established by Royal Decree of 12 February 1934, No. 6.2.

Report of the Committee on the membership of representative bodies 1934, p. 7-8.

Afdeling geschillen van bestuur.

Wijman 1995, p. 10-11.

Ibid. 
solution could only be reached by an amendment of constitutional immunity. ${ }^{133}$ When the government established a new committee in 1936 that was assigned with the task to investigate the desirability of constitutional amendments in several areas and to make recommendations accordingly, the possibility to introduce measures against 'revolutionary' members of representative bodies was therefore one of the points of attention. ${ }^{134}$

The committee subsequently came up with a proposal to amend the constitutional non-accountability provision of Article 98. According to the proposed amendment, the phrase 'except for sedition or betrayal of secrets' was to be added to the article which prohibited the judicial prosecution of members for what they had said in their chamber or submitted to it in writing. ${ }^{135}$ The government later took over the committee's proposal without making any changes. In the explanatory memorandum, it argued that sedition and betrayal of secrets needed to be exempted from the protection of non-accountability because the harm caused by these particular forms of criminalised speech could not be prevented or undone by any sanction at the disposal of the chairperson. After all a state secret, once betrayed to the public, could not be made unheard. ${ }^{36}$ However, the proposal to change Article 98 later failed to achieve the necessary majority in the States-General.

In addition to an amendment of Article 98, the committee proposed to amend Article 86, which stipulated that the term of the mandate of members of the Second Chamber was four years and that they could be re-elected. To the existing text, the committee proposed to add the following:

During the term of their mandate, the Council of State may declare the forfeiture of their membership, if they express an intention aimed at changing the existing legal order by using or facilitating unlawful means.

Statute shall determine the applicable procedure as well as the consequences of forfeiture; the consequences may also concern membership of other representative organs mentioned in the constitution. The seat of a member whose mandate has been forfeited remains vacant for the remainder of the term. ${ }^{137}$

The government agreed with the committee in principle but made one significant change to the proposed amendment of Article 86. Instead of leaving the task to judge the potentially revolutionary intentions of parliamentarians to the Council of State, the amendment bill which was eventually introduced by the government left it to the individual chambers of the States-General themselves to declare the forfeiture of a member's mandate with an elevated majority of two thirds.

When the amendment bill on Article 86 was debated in the Second Chamber, it was criticised as being both too vaguely formulated and too limited, because it

Wijman 1995, p. 2

134 Committee on partial revision of the constitution, unofficially named after its chairman de Wilde, established by Royal Decree of 24 January 1936.

Report of the Committee on partial revision of the constitution 1936, p. 36.

Handelingen Staten-Generaal 1935-1936, No. 477, 15, p. 13.

Handelingen Staten-Generaal 1935-1936, No. 477, 18, p. 20. 
provided for forfeiture of the mandate as the only possible sanction. ${ }^{138}$ The main point of controversy, however, was still the question to which forum the power to declare the forfeiture of the parliamentary mandate should be attributed. In particular, the argument was put forward that this power should not be left to the chamber itself; the potential for abuse of this, in essence, judicial power by political actors would be too great, regardless of the supermajority required to deprive a member of his mandate. ${ }^{139}$ Instead, a compromise was adopted which would leave the power to declare the forfeiture of the parliamentary mandate to a special body, on whose composition the Chamber would, however, have a decisive influence. Hence, the proposal to revise Article 86 of the Constitution was amended to read as follows:

The members of the Second Chamber are elected for four years. They stand down at the same time and their mandate is renewable.

During the term of their mandate, their membership can be declared forfeited by a body [college] established by statute, if they express an intention aimed at changing the existing legal order by using or facilitating unlawful means.

Statute shall determine the composition of the body mentioned in the second paragraph, but each of its members shall be appointed by the King from a list of three persons put forward by the Second Chamber. Statute shall further determine the applicable procedure as well as the consequences of forfeiture; the consequences may also concern membership of other representative organs mentioned in the constitution. The seat of a member whose mandate has been forfeited remains vacant for the remainder of the term. ${ }^{140}$

The final proposal for constitutional revision was adopted in first reading by large majorities in both chambers. ${ }^{141}$ After new elections, however, the amendment failed to yield the necessary majority of two thirds in the Second Chamber by a very large margin. ${ }^{142}$

Consequently, the constitutional revision of 1938 did not bring about a limitation of freedom of speech in parliament - neither by means of exempting certain content of parliamentary speech from non-accountability nor by introducing a sanction for members who agitated against the constitutional system. Even though, during a time of increasing political radicalism both in and outside parliament, the need to develop legal mechanisms against 'revolutionary' agitation

138 For a more detailed account of the arguments exchanged in the Chamber, see Wijman 1995, p. 15-18.

$139 \quad$ Kranenburg 1947, p. 327.

$140 \quad$ Handelingen Staten-Generaal 1936-1937, No. 105, 33, p. 65

141 The procedure for constitutional amendment requires that the proposed amendment be adopted in first reading by both Chambers according to the ordinary legislative procedure. Subsequently, the Chambers are dissolved (usually at the instance of regularly scheduled general elections) and both Chambers of the newly elected States-General have to confirm the amendment by an elevated majority of two thirds (Art. 198 of the constitution of 1922; Art. 137 of the constitution of 1983).

14260 of 97 votes cast were against the amendment, $c f$. Wijman 1995, p. 18. 
was widely perceived, the Dutch parliamentary immunity regime remained unchanged.

While the concerns about anti-democratic currents in Dutch politics - and of course about the developments in Germany - were grave and justified, the reason why the attempt to limit free speech in parliament failed was a strong and deeply rooted belief in the strength and resilience of the parliamentary system. The arguments and reservations put forward against constitutional amendments which would limit freedom of parliamentary speech and impose sanctions on those who use their parliamentary mandate to promote anti-democratic revolution were mainly inspired by this belief and the resulting opinion that any such amendment would create more problems than it could solve. Much less emphasis was put on legal considerations or constitutional theory, according to which uninhibited parliamentary debate was crucial to the democratic system and indispensable for national will-formation - arguments which have historically played a very significant role in upholding parliamentary immunity in other countries and, to a large extent, continue to do so. The influential Dutch constitutionalist Kranenburg, reflecting on the failed amendments in 1938, phrased the prevailing opinion as follows in his standard volume Nederlandsch Staatsrecht:

In my view, a state with free institutions as ours is in abstracto entitled to take measures through which members who use their competences to the detriment of the system itself are deprived of the possibility to do so.

\begin{abstract}
Another question is whether such measure would be expedient here and now? I answer this question in the negative, for the following reasons. The place where destructive elements are least dangerous is the Dutch parliament. In our parliament we are more sensitive to speech which violated the legal order, to revolutionary speech, than anywhere else. Nowhere is seditious speech cooled down in an ice-cold bath of criticism and irony more quickly than [in the Dutch parliament]. ${ }^{143}$
\end{abstract}

It is probably not due to an editorial lapse - or editorial irony - that the very same passage can be found in the 6th edition of Nederlandsch Staatsrecht of 1947, now published with the German occupation and the collaboration of many of those 'destructive elements' with the Nazis freshly in mind. Rather, the Dutch attitude towards freedom of speech in parliament had not changed significantly even after the Nazi reign, and was not going to change in the decades to come.

In 1950, a new committee on general revision of the constitution was established. ${ }^{144}$ This committee, again, occupied itself with the question of how to proceed with revolutionary members of parliament and whether to exempt sedition and betrayal of secrets from freedom of parliamentary speech. However, in its final report of 1954, the committee found that no constitutional amendments should be made:

$143 \quad$ Kranenburg 1938, p. 321.

144 Established by Royal Decree of 17 April 1950, unofficially named commissie van Schaik after its chairman. 
Parliamentary Immunity in the Netherlands

The committee is of the opinion that it should not take over the proposal, made on the occasion of the constitutional revision of 1938 , to lift parliamentary immunity as a consequence of sedition and betrayal of secrets. It deems the principle of parliamentary immunity, which was adopted in England already with the Bill of Rights of 1689 and later taken over by all countries with a free parliament, too precious to deviate from it without any evident necessity.

The Chambers must react to seditious speech themselves: the rules of procedure contain sufficient disciplinary measures. Also with regard to betrayal of secrets there is, in the opinion of the committee, no need to lift parliamentary immunity. Lifting would, moreover, have little effect, since a person who is willing to betray a secret will usually not do so in the Chamber. If, however, the betrayal takes place outside the Chamber, the member can already be prosecuted according to the criminal law. This is equally true in case of sedition. ${ }^{145}$

Hence, to this date no amendment has been made to the Dutch Constitution which would limit the freedom of parliamentary speech, either in the form of a material exemption of certain content from that freedom, or in that of sanction - such as forfeiture of the mandate - other than those at the disposal of the chairman by virtue of the Rules of Procedure.

The last inconspicuous, yet significant, change in the wording of the constitutional immunity provision was made in the constitutional revision of 1983 . Whereas that provision - Article 107 after the last renumbering of 1972 - had previously stipulated that the members of the States-General, ministers and other persons mentioned 'cannot be judicially prosecuted [zijn niet gerechtelijk vervolgbaar] for what they have said in the meeting or submitted to it in writing', this was rephrased to read '[...] cannot be prosecuted or held legally liable [kunnen niet in rechte worden vervolgd of aangesproken] [...]'. This is the current text of what is now Article 71 of the Dutch Constitution. According to the explanatory memorandum with the proposed revision, the purpose of this last, rather tiny, amendment to the immunity provision was to express that the immunity did not only free the designated persons from criminal, but also from civil liability for their utterances in parliament. ${ }^{146}$ The amendment of 1983 did not, however, constitute a material change in the immunity system but only a clarification: as pointed out earlier, it was established in case law that immunity also covered civil liability.

To this date, the amendment of 1983 has marked the last act in the development of the Dutch system of parliamentary immunity. Even though in recent debates (see part III, section 4) the desire has been expressed to broaden the scope of Article 71 or to replace parliamentary immunity with a wider, political immunity altogether, actual legislative and constitutional developments in this direction do not seem imminent at the moment. 


\title{
3. The Dutch Immunity System Today
}

After having discussed the origins and the historical development of parliamentary immunity in the Netherlands, the content of the current immunity system will be examined more closely. This will be done in four steps: First, a detailed account will be given of the scope of non-accountability under Article 71 of the Dutch Constitution. Second, a closer look will be had at the disciplinary powers of the States-General to see what means the Chambers and their respective chairpersons have at their disposal to regulate parliamentary speech (which by virtue of nonaccountability is exempt from ordinary justice). Third, an assessment of Article 119 of the Constitution will show whether this provision has an actual or potential 'immunity dimension', that is, whether and under which circumstances the special procedure for crimes committed in office can be considered part of the immunity system. Lastly, we will review the recent exchange of arguments about the adequacy of the limited immunity of Dutch parliamentarians and the question of whether it should be broadened into 'political immunity'.

\subsection{The Scope of Non-accountability ex Article 71 of the Constitution}

\author{
'De leden van de Staten-Generaal, de ministers, de staatssecretarissen en andere \\ personen die deelnemen aan de beraadslaging, kunnen niet in rechte worden vervolgd \\ of aangesproken voor hetgeen zij in de vergadering van de Staten-Generaal of van \\ commissies daaruit hebben gezegd of aan deze schriftelijk hebben voorgelegd'.
}

The members of the States-General, the ministers, the secretaries of state and other persons who participate in deliberations may not be prosecuted or held liable for what they have said in the meetings of the States-General or of committees thereof, or for what they have submitted to them in writing.

If we compare the wording of Article 71 to that of Article 9 of the English Bill of Rights of 1689, it becomes apparent that the modern Dutch provision is phrased much more clearly: '[...] what they have said in the meetings of the States-General or in committees thereof, or [...] what they have submitted to them in writing' seems unambiguous as compared to 'proceedings in Parliament'. The same is true for 'may not be prosecuted or held liable' as compared to 'ought not to be impeached or questioned'. Nevertheless, for a good understanding of the precise scope of the Dutch non-accountability system, it is worth paying attention to some points regarding the exact interpretation of Article 71.

In most cases, the wording of Article 71 leaves no doubt as to whether or not a given utterance is covered by non-accountability. Usually the case is obvious, as the requirements of Article 71 are clear: for instance, a member of the States-General, speaking in a TV studio, will not be entitled to non-accountability despite his parliamentary mandate, because non-accountability is only effective in the parliamentary meeting. In other cases, the situation is less clear. Suppose that a member delivers a speech in his chamber which contains criminal utterances, and that this member later publishes the text of his speech as an article in a newspaper - 
may this member be prosecuted? If so, is the situation different in case of a TV broadcast of the parliamentary debate or a quotation in the press which is not published on the member's own motion? Does non-accountability extend to the testimony of non-members who are merely heard as witnesses in parliamentary committees but do not participate in deliberations in a strict sense? To answer these questions and others that are similar, it is first of all necessary to note that the elements of Article 71 always need to be fulfilled cumulatively, id est, in particular, that the temporal, personal and material criteria for non-accountability all have to be met in order for Article 71 to take effect. ${ }^{147}$

\subsubsection{Personal Scope}

\subsubsection{Members, Ministers, Secretaries of State}

The personal scope of parliamentary non-accountability in the Netherlands is unusually broad: it covers not only members of the States-General but also ministers, secretaries of state (also referred to as junior-ministers) and 'other persons who participate in deliberations'. With regard to members of the States-General, it is clear that non-accountability only covers utterances made by them during the time of their mandate. However, as non-accountability is in any case limited to utterances made in parliamentary meetings, the precise point in time at which the parliamentary mandate begins and ends is not as contentious in the case of the Netherlands as, for instance, it is in the case of inviolability in France, where much depends on this question.

The inclusion of ministers and secretaries of state in Article 71 is motivated, on the one hand, by the incompatibility of government office with the parliamentary mandate, due to which ministers and secretaries of state cannot be members of either chamber. ${ }^{148}$ On the other hand, the Dutch Constitution provides that legislative power is exercised by the States-General and the government jointly. ${ }^{149}$ To extend the immunity system to members of the government is therefore consistent with the logic of the constitution, even if it is at odds with a traditional view of parliamentary immunity as a means of protecting the legislature against the executive. ${ }^{150}$

\subsubsection{Other Persons}

The inclusion of 'other persons who participate in deliberations' in the scope of nonaccountability gives rise to the question who these other persons are and under

$147 \quad$ Nieuwenhuis and Janssens 2011, p. 387.

148 Art. 57(2) of the Dutch constitution provides that a member of the States-General may not at the same time be a minister, secretary of state, member of the Council of State or a member, procurator-general or Advocate General of the Supreme Court.

149 Art. 81 of the Constitution provides that 'statutes are made jointly by the government and the States-General'

$150 \quad$ Elzinga and De Lange 2006, p. 572 
which circumstances a person is considered to take part in parliamentary deliberations. The purpose of including 'other persons' in Article 71 was to grant non-accountability to non-members who participate in parliamentary debate with the permission or upon the invitation of the chambers or one of its members, a minister or secretary of state. This may be the case, for instance, where nonmembers - such as civil servants - are invited to help explain and defend a legislative proposal in support of the initiator or the government. It is for the chambers themselves to determine which persons are considered to take part in deliberations. ${ }^{151}$ Persons who merely attend the meetings of a chamber or committee either on their own motion or upon an invitation but who are not deemed to take part in deliberations are never covered by parliamentary non-accountability for what they might say during the meeting. ${ }^{152}$

A person who is heard as a witness or expert by one of the chambers or a committee does not fall under the category of persons who take part in deliberations and, as such, remains legally responsible for his oral and written utterances. ${ }^{153}$ Likewise, persons who provide or contribute to written evidence and reports, even where these are commissioned by a chamber or committee, do not enjoy non-accountability.

The latter has been established in one of the very few judicial decisions with regard to the immunity of the Dutch national parliament, the Van de Bunt case of 2002.154 In 1996 the parliamentary enquiry committee on methods of criminal investigation (parlementaire enquetecommissie opsporingsmethoden) submitted its final report to the Second Chamber. Attached to the final report were pieces of written evidence used by the committee, among which was a study on organised crime in the Netherlands. This study had been commissioned by the enquiry committee but written by members of an independent research group in their own name. One case study in this research described the case of a company which had allegedly engaged in money laundering. A lawyer who had been a member of the supervisory board of this company at the material time subsequently brought civil proceedings against the author of this particular case study. According to the lawyer, the case study had been researched without the necessary care and contained false information which had caused him material and immaterial damage, since his identity had not been properly concealed (the press had found out the lawyer's name and described him as 'blacklisted by the enquiry committee'). The district court ordered the researcher to pay a large sum in damages, and this judgment was later upheld on appeal.

In cassation, the author of the case study argued that he could not be held liable, since he was protected by parliamentary non-accountability under Article 71 of the Constitution. Alternatively, he claimed 'derivative immunity' (afgeleide immuniteit), arguing that the non-accountability of the members of the enquiry committee would to a large extent become illusory if persons working under commission and under the responsibility of the committee could themselves not 
rely on immunity, as this could make it hard for the committee to find experts willing to help. The Supreme Court considered that non-accountability is limited in two ways: on the one hand, it is limited materially to what persons entitled to nonaccountability have said in, or submitted in writing to, the meetings of the StatesGeneral. On the other hand, it is limited with regard to the persons who are entitled to claim non-accountability, either because they are members, ministers or secretaries of state, or because they fall under the category of 'other persons taking part in deliberations'. That the final report of the enquiry committee falls under the category of what members have submitted to the States-General in writing was undisputed, since its primary authors - the members of the enquiry committee were members of the States-General. The question which remained, therefore, was whether non-members who had contributed material for this report and who had acted on the invitation of the committee, must be deemed to be 'other persons taking part in deliberations' of the States-General. According to the Court, this is not the case. The Court based its view on its interpretation of the term 'deliberations' (beraadslagingen) in Article 71 of the Constitution:

\begin{abstract}
It does not follow from the fact that the report of the enquiry committee with all its annexes belongs to the documents to which parliamentary immunity applies [...] that the author of any document attached to the report as an annex [...] must be considered a person who takes part in the deliberations of the Second Chamber or the deliberations of the enquiry committee. After all, the word 'deliberations' in article 71 must be understood as 'parliamentary debate', thus the written or oral exchange of thoughts and views in a meeting of the Chamber or a committee. Providing assistance to the enquiry committee does not entail the right [...] to take part in parliamentary debate. Also the fact that the applicant's research was carried out under the responsibility of the enquiry committee does not lead to immunity. ${ }^{155}$
\end{abstract}

With regard to the applicant's claim to 'derivative immunity', the Supreme Court adopted a relatively narrow view of the purpose of Article 71. With reference to the constitutional history of parliamentary immunity in the Netherlands, it held that the purpose was 'to grant the participants of parliamentary deliberations optimal freedom of speech without having to fear criminal prosecution or civil liability for what they have said' - and not, for instance, to enable an enquiry committee to fulfil its mandate in an optimal way. The Court continued that 'to safeguard this freedom of speech, a derivative immunity for an external expert who has written two partial reports on behalf and under the responsibility of the parliamentary enquiry committee is not necessary'.156 As far as the applicant's claim to 'derivative immunity' contains the argument that the absence of such immunity would hamper the effective discharge of the tasks of a parliamentary enquiry committee, the Court remarks that, even if that were the case, it would 'exceed the Court's duty to develop the law [rechtsvormende taak] to extend parliamentary immunity to other persons than those mentioned in Article 71 as participants in parliamentary 
deliberations'. ${ }^{157}$ Moreover, the Supreme Court pointed out that parliamentary immunity is not the only way in which the applicant could have been protected from civil and criminal liability: he would not have incurred any problems if he had been consulted by the committee without contributing to the report in his own name. Also, if he had been heard by the committee as an expert, he would not have run the risk of civil or criminal liability. Article 30 (then Article 24) of the Parliamentary Enquiry Act (Wet op de parlementaire enquête) prohibits the use of a person's testimony before a parliamentary enquiry committee as evidence in legal proceedings, both against that person himself and against third persons. The Court therefore advised that a rule be included in the parliamentary rules of order which would allow parliamentarians to be assisted by persons who participate in deliberations in their own name. This did not help the applicant in the particular case at hand, so the Court also hinted at the possibility that the state could compensate him for the damage he had to pay. ${ }^{158}$

The Supreme Court's decision in this case is remarkable in two respects. First, because it draws a virtual dividing line between the written utterances which gave rise to the lawsuit - the case study written by the applicant and attached to the committee report as evidence - and its factual author. Even though the contested case study eventually became a part of the report, which undisputedly fell within the regime of Article 71, this did not lead to non-accountability for its author. Even though it is certainly correct that authorship of the final report of the enquiry committee is attributed to the non-accountable members of that committee, it is not without a certain aftertaste that the clearly identifiable author of one particular part of this report is denied the same non-accountability. This is not to say that the Court's assessment, based on a reasonable definition of 'deliberations' and the persons who take part in them according to Article 71, is incorrect. However, it highlights an interesting aspect of the question whether parliamentary immunity is a personal or an institutional privilege. Throughout this book, we find strong evidence for the latter. The Van de Bunt case, however, shows that this distinction is not always helpful: if we accept that immunity attaches primarily to parliament as an institution, it should follow that 'parliamentary utterances' are immune - as is confirmed by the fact that the report of the enquiry committee itself did in principle fall under non-accountability. In the United Kingdom, it would thus of course have constituted a 'proceeding in Parliament'. However, the wording of Article 71 of the Dutch constitution caused the Dutch Supreme Court not to choose its being incorporated in a parliamentary report as the defining factor for the parliamentary nature of the relevant case study, but the capacity of its author. In other words, the Court opted for a personal criterion. In conclusion, there is a subtle but potentially important difference between an immunity for 'proceedings in Parliament' and freedom of speech for participants in parliamentary deliberations. It is as a result of this difference that the Dutch non-accountability system, even though it is intended 
as an institutional privilege, has a much more personal character than the British system of privilege.

The second remarkable aspect of the Van de Bunt case is the immediacy with which the Court dismissed the necessity of 'derivative immunity'. The Court did correctly point out that liability of the defendant could easily have been avoided even without granting him non-accountability, for instance by hearing him as an expert instead of attaching his case study to the committee report under his own name. For the case at hand, this argument is certainly decisive. However, the Court also stated that 'derivative immunity' is unnecessary because the purpose of nonaccountability pursuant to Article 71 is actually limited to 'optimal freedom of speech' for members and other participants of parliamentary deliberations. But is there not some merit to the applicant's argument - put bluntly - that freedom of speech for parliamentarians would be futile if there was nothing to say because external experts are reluctant to submit information? The Supreme Court stated that extending non-accountability beyond what is dictated by the wording of Article 71 would exceed its competences; and it could afford to do so because the Parliamentary Enquiry Act does provide a feasible alternative way to protect experts in enquiries. But this does not solve the underlying systemic issue with regard to the purpose and functioning of parliamentary immunity. Nieuwenhuis and Janssens, in their book on crimes of utterance, argue that the court's ruling in Van de Bunt is dissatisfactory because 'in this case the process of establishing the truth in parliament is pre-eminently at issue' ${ }^{159}$ Nevertheless, they stop short of the conclusion that the Court's interpretation of Article 71 is flawed and instead argue for a practical solution, saying that the protective capacity of the law on parliamentary enquiry should be broadened even more, so as to cover cases as the one in Van de Bunt. ${ }^{160}$

\subsubsection{Can the State be Held Liable Instead?}

Article 71 of the Dutch Constitution leaves no doubt that members of the StatesGeneral, ministers, secretaries of state and other persons cannot be held personally liable for what they have said in parliamentary meetings, and that this nonaccountability does not only cover only criminal but also civil liability. But members of the government are also organs of the state. The question therefore arises whether persons who incur damage or are otherwise injured as a consequence of utterances of members of the government can hold the state liable in lieu of the minister or secretary of state personally.

This question has been at issue in two Dutch cases. In 1986, the case of Harm Dost was discussed in the First Chamber during question time. Dost, a drug dealer of Dutch nationality, had been sentenced to prison by a German court for drugrelated crimes committed in the Netherlands, where he had already been sentenced for the same offences in the past. The Minister, Secretary of State of Hustice, and the

159 Nieuwenhuis and Janssens 2011, p. 388.

$160 \quad$ Ibid. 
Minister of Foreign Affairs provided the members of that chamber with information which Mr Dost later claimed to be wrong and misleading. He argued that this information had disadvantageous consequences for him, because the chamber was unable to exercise parliamentary control on the policy of the government (he claimed that the government had failed to support him when he stood trial in Germany). Legal action against the Ministers and the Secretary of State personally was barred due to non-accountability ex Article 71 of the Constitution, so Mr Dost sued the Dutch state, among others, for rectification of the truth and an injunction which would oblige the government to make good the disadvantages he had suffered. ${ }^{161}$ His claim was based on a restrictive reading of Article 71, which, according to the applicant, referred to the ministers and the secretaries of state as persons and not as state organs.

The court first expressed its reluctance to limit the scope of a provision of the 'brand new constitution' so soon after its adoption. Subsequently, it argued that the purpose of Article 71 was that 'ministers and secretaries of state must be able to speak out in the meetings of the States-General without reservation, that is, in the knowledge that the lawfulness of their utterances will not be subject to judicial control'. $^{162}$ According to the court, the reading of Article 71 proposed by the applicant would, however, require the courts to test the lawfulness of utterances of members of the government in order to reach a conclusion about the liability of the state. Therefore, the court concluded that the interpretation of Article 71 proposed by the applicant would defy the purpose of non-accountability and is therefore wrong. ${ }^{163}$ Consequently, the state cannot be held liable for wrongful utterances of members of the government in parliament.

In the case Rost van Tonningen of 1993,164 the Dutch Supreme Court considered a similar question amongst an entirely different line of argumentation. An antifascist organisation had filed a lawsuit against the state, in which it demanded that it be prohibited to publicly state the opinion that the widow of the prominent Dutch national socialist parliamentarian and wartime collaborator Rost van Tonningen should be entitled to a pension. In parliament, the government had stated that the widow's controversial pension claims were justified. It argued that Article 71 precluded a prohibition as demanded by the applicants. Nevertheless, the Supreme Court did not base its decision on non-accountability, as could have been expected: it held that the government enjoyed freedom of expression by virtue of Article 10 ECHR and case law of the European Court of Human Rights - a ruling which has been criticised as strange and erratic. ${ }^{165}$ Nevertheless, this case confirms that the Dutch judiciary is more than reluctant to hold the state to account for (or to impose limits on) utterances of members of the government in parliament.

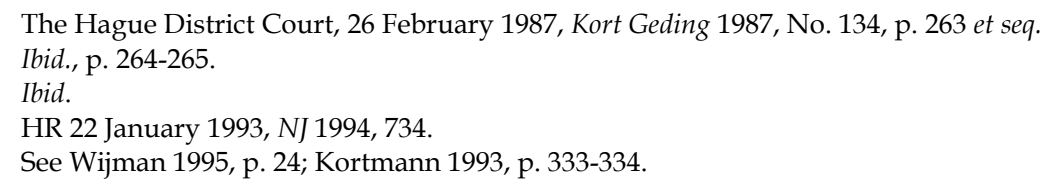




\subsubsection{Temporal and Spatial Scope}

\subsubsection{No Spatial Privilege}

Non-accountability in the Netherlands is not a 'spatial privilege'. This means that it is not limited to a specific geographical location, in the sense that the location at which an utterance is made would in itself constitute a criterion for the application of Article 71. This is because it follows neither from the Constitution nor from the Rules of Procedure of the two chambers that a parliamentary meeting is defined by its place - though of course, in practice, meetings are held at the Binnenhof, the building which houses the States-General. The location of a chamber of the StatesGeneral or committee meeting does not matter, as long as the utterance in question is made at that location during the meeting. Accordingly, it is not entirely correct to speak of Dutch non-accountability as a 'spatial' or 'geographical' privilege, as is often done in the Dutch literature. ${ }^{166}$ Rather, non-accountability is attached to the States-General as a body. While this difference is of little importance for the practical application of non-accountability, it underlines the logic and institutional character of parliamentary immunity. Whether a meeting qualifies as the meeting of a parliamentary committee is to be determined by the chambers themselves in their respective Rules of Procedure. ${ }^{167}$ It is clear, however, that meetings of parliamentary political groups do not qualify as meetings of a parliamentary committee; neither do meetings of a committee which do not consist of members of the States General, even when that committee has been established by the States-General or one of its chambers. ${ }^{168}$

\subsubsection{Non-accountability for the Duration of the Meeting only}

Non-accountability ex Article 71 of the Constitution is strictly limited to the duration of the meetings of either chamber of the States-General or a committee. This means that the oral utterances of persons entitled to non-accountability are only protected if made while the respective meeting is ongoing, so that anything said in the plenary hall or in the meeting place of a committee before the beginning or after the conclusion of the respective meeting is not covered by nonaccountability. The logic of parliamentary immunity demands that the words in de vergadering in the Dutch original of Article 71 have to be understood as 'during the meeting' and thus, have to be ascribed a temporal meaning rather than a (merely) spatial one: it is only while the meeting of a chamber or a committee is on-going that an utterance in parliament has significance for the parliamentary work. Therefore, only utterances made during the meeting deserve the protection of nonaccountability.

166 See for instance Bovend'Eert and Kummeling 2010, p. 144.

167 Handelingen Tweede Kamer 1978-1979, No. 14224, 6, p. 10. Rules with regard to committees are contained in Chapter VII of the Rules of Procedure of the Second Chamber and in Chapter III of the Rules of Procedure of the First Chamber. 
The above was confirmed at the only instance at which the precise time of an utterance in parliament - before or after the conclusion of the meeting - was decisive in legal proceedings about the question of whether or not an utterance was protected by non-accountability. In 1939, a member of the National Socialist Movement, the abovementioned Rost van Tonningen, was expelled from the plenary meeting of the Second Chamber for repeated inappropriate statements. After the Chairman had subsequently declared the meeting adjourned, another member called Rost van Tonningen 'a traitor', for which he was later sentenced to a fine by the District Court of The Hague. The Court found that the accused member was not protected by non-accountability, since the word in question had been spoken after the conclusion of the meeting. ${ }^{169}$

\subsubsection{Material Scope}

\subsubsection{No Limitations with Regard to the Content of Utterances Covered by Non- accountability}

Where an utterance is made by a person entitled to non-accountability and in a situation in which non-accountability is due (such as in a parliamentary or committee meeting), Article 71 of the Constitution does not impose any further requirements in order for the immunity to take effect. In particular, there are no conditions with regard to the form or content of the utterance in question or the precise situation or context in which it is made. Thus, non-accountability applies to the content of committee reports, to speeches made from the lectern, but also to spontaneous interjections of any kind, whether or not they relate to the issue which is currently being discussed in a meeting. This has already been expressed by the constitutional legislator of 1887, when he exchanged the opaque term 'advice' for 'what they have said in the meeting'.

Proof that the comprehensive protection of non-accountability also holds in extreme cases of insults which are manifestly unrelated to the subject of parliamentary debate was recently confirmed in an Aruban case of $2011^{170}$ which was decided by the Dutch Supreme Court in final instance. ${ }^{171}$ The defendant in cassation, at the relevant time an Aruban minister, had, in an oral interjection during a speech delivered by the applicant in parliament, called the applicant a 'paedophile' and asked him to 'explain this to all the children you abused'. ${ }^{172}$ These words did not have any connection with the issue that was being debated in the Aruban parliament at the time. When sued by the applicant, the trial court ordered

\footnotetext{
169 Ibid., p. 145

170 According to the Kingdom Act on Jurisdiction in Cassation (Rijkswet Cassatierechtspraak), the Supreme Court of the Netherlands functions as the court of cassation for Aruba and the states of the former Dutch Antilles. Accordingly, the case law of the Supreme Court with regard to parliamentary non-accountability in Aruba is of significance to the Netherlands where it concerns a legal question relevant to both countries.

171 HR 17 June 2011, NJ 2011, No. 450.

$172 \quad$ Ibid., para. 3.v.
} 
the defendant to publish a rectification. On appeal, however, he made a successful claim to parliamentary non-accountability, which is laid down in Article III.20 of the Aruban constitution in terms identical to Article 71 of the Dutch Constitution. In cassation before the Dutch Supreme Court, the applicant argued that (a) nonaccountability in this case constitutes a violation of Article 6 ECHR, since it bars access to court for the applicant, and that (b) non-accountability does not apply in this case, since the utterances in question were entirely unrelated to the parliamentary debate at the time in which they were made.

With reference to ECtHR case law in A. v. United Kingdom, ${ }^{173}$ the Supreme Court held that non-accountability does not violate Article 6 ECHR, since it is necessary to safeguard freedom of opinion in parliament and the separation of powers between the legislator and the judiciary. ${ }^{174}$ With regard to the second argument, the Court simply stated that the same reasoning leads to the conclusion that a limitation of non-accountability to matters which relate to the actual parliamentary debate would constitute an unduly restrictive interpretation of Article III.20 of the Aruban constitution. ${ }^{175}$ The Dutch Supreme Court has thus confirmed that parliamentary non-accountability covers all utterances which fall within the personal and temporal scope of Article 71, regardless of their content.

Inviolability, the extra-professional immunity which many states grant their parliamentarians, has increasingly been subjected to pressure from the European Court of Human Rights, essentially limiting its legitimate scope to matters which are at least potentially connected to the parliamentary work of the member in question. So far, this has not been the case for non-accountability, even though several European countries know systems of non-accountability which exclude grave insults from the material scope of the immunity. ${ }^{176}$ That the material absoluteness of non-accountability in the Netherlands remains uncontested is owed to the notion of a complete separation of power between the legislator and the courts, which the Dutch traditionally hold in high esteem. ${ }^{177}$ Both the Dutch national courts and the ECtHR have thus far observed this strict separation of powers with regard to crimes of utterance in parliament.

\subsubsection{No Immunity for 'Private' Publications, even if Identical to Protected Utterances}

Written utterances of members or other persons entitled to non-accountability are protected only if they are submitted to a parliamentary chamber or committee. In order to answer the question of whether a published written document falls under the material scope of non-accountability, it is therefore decisive whether or not the material in question has been published as a parliamentary document - for instance,

ECHR 17 December 2002, Appl. No. 35373/97; see Chapter II.

HR 17 June 2011, NI 2011, No. 450, para. 3.4.2.

Ibid., para. 3.5.2.

See e.g. Art. 46 of the German constitution.

This is also the tenor of the case note by Egbert Dommering on HR 17 June 2011, published on the website of the Institute for Information Law (Instituut voor informatierecht, IViR) at the University of Amsterdam. 
in the official parliamentary records or a committee report whose publication is commissioned by a chamber of the States-General. Non-accountability is excluded for any material published 'privately'.

The latter is illustrated by case law of the Supreme Court with regard to nonaccountability on the municipal level. ${ }^{178}$ A member of the municipal council of Dordrecht had delivered a speech at a council meeting. As was later established in court, passages of this speech contained insults against citizens of foreign descent and encouraged racial hatred and discrimination. Immediately after the meeting, the council member handed a written copy of the text of his speech to a local journalist. While doing this, he expressed to the journalist his hope for media attention. The journalist later quoted the relevant passages in an article, whereupon the council member was prosecuted for, and found guilty of, incitement of racial hatred, as the courts in first instance and on appeal interpreted the act of handing the text of the speech to a journalist as evidence of the intention to see it published. 179

Before the Supreme Court, one of the grounds for cassation put forward by the applicant was a claim to non-accountability ex Article 22 of the Municipalities Act, whose wording is equivalent to that of Article 71 of the Constitution. The Supreme Court, however, held that 'the protection against judicial prosecution offered by said provision does not extend to acts other than those mentioned in that provision'. Speaking in the council meeting and submitting written utterances to the council: 'It follows from this that the defendant does not enjoy immunity for the handing over of the text of his speech to a person other than the members of the council and outside the council meeting'. ${ }^{\prime} 80$

This case carries two important consequences for the assessment of the material scope of parliamentary non-accountability. First, where a member is not to be held accountable for an utterance in the States-General, he cannot 'export' that non-accountability and rely on it for the same utterance repeated in a nonparliamentary context. The limitation of non-accountability to parliament thus has to be interpreted strictly. Second, in order for a member of a representative organ to incur liability for the publication of an utterance during the meeting, this publication must be directly attributable to him. This is the reason why the Supreme Court attaches some importance to the fact that the council member in this case had apparently intended his utterances to be published, and had given the text to the journalist for this purpose. ${ }^{181}$ It is reasonable to assume that, as a prerequisite for d councils of mayor and aldermen also enjoy non-accountability, laid down in Arts. 22 and 57 of the municipalities act in terms identical to those of Art. 71 of the constitution.

179 HR 2 April 2002, NJ 2002, 421, para. 3.5. Since factual evidence cannot be reviewed in cassation proceedings, the Supreme Court did not question this intention.

$180 \quad$ Ibid., para. 4.3 .

181 Ibid., para. 3.5. The Supreme Court notes that cassation proceedings do not allow a factual reexamination of the case, but it recapitulates the evidence on which the court of appeal had based its view that the applicant had intended the publication of his speech and comes to the conclusion that, in the light of this evidence, the guilty verdict of the court of appeals does not display an incorrect interpretation of the law. 
liability, the courts will have to establish that the member in question actively encouraged or facilitated the publication. Accordingly, publication without the active support or assistance of the member concerned does not lead to liability, even though the member might foresee and welcome publication of his utterance - think of live television broadcasts of debates in the Second Chamber, of which the members are of course aware. It is logical that this or any other form of publication without the active support of the relevant member does not lead to liability, since in such a case the member cannot be imputed with any act but that of making the utterance for which he is non-accountable in the first place.

\subsubsection{All Forms of Legal Action are Barred}

Non-accountability ex Article 71 of the Constitution does not only bar criminal prosecution but also civil action. As mentioned previously, the latter is the intended meaning of the words 'prosecuted or held liable' (vervolgd of aangesproken) in the text of Article 71. It is assumed that these words also cover disciplinary action under public law. ${ }^{182}$ With regard to disciplinary action under private law, however, the situation is less clear, and so far no precedent is available which could provide a definite answer, although Elzinga and de Lange note in this regard:

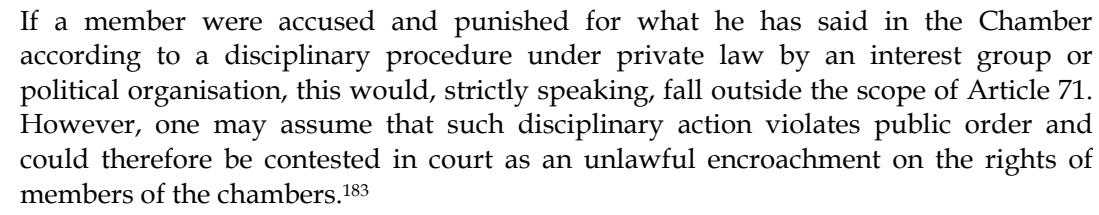

Bovend'Eert and Kummeling recount a parliamentary episode during which three members of the party group of Lijst Pim Fortuyn, all of them also medical experts, wished to abstain from a vote in the Second Chamber on an amendment of a Tobacco Act for fear of disciplinary action by the medical disciplinary board (medisch tuchtcollege). They had to be reminded that abstentions were not possible, (in case of a vote by roll call) ${ }^{184}$ and that one can never be held liable for what one has said in the chamber, nor for the parliamentary vote. ${ }^{185}$ Even if some doubt remains with regard to disciplinary mechanisms under private law, it follows from the logic of non-accountability that any form of legal action is prohibited. In all likelihood, the bar on legal action pursuant to Article 71 of the Constitution does not, therefore, contain any exceptions.

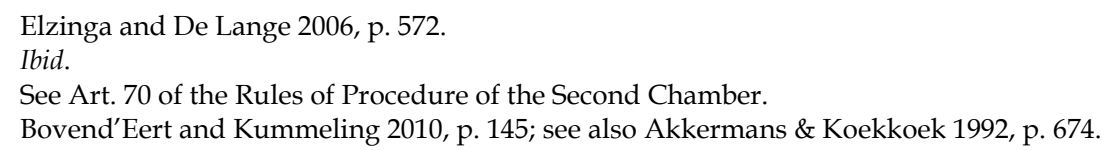




\subsection{The Disciplinary Powers of the Chambers}

As in most systems of parliamentary immunity and in all three countries discussed in this study, non-accountability in the States-General is not tantamount to unlimited freedom of speech. Even though, as we have seen, all forms of legal action are barred, the parliamentary chambers themselves remain responsible for the maintenance of order during debates. To this end, the Rules of Procedure of both chambers provide for a range of disciplinary measures which the respective chairman has at his disposal to maintain order. ${ }^{186}$ Decisions taken by the chairman in this respect are never open for appeal. ${ }^{187}$

First, the chairman can admonish a member who disturbs the order in the chamber if that member's speech contains insults, betrays secrets or expresses approval of or incitement to unlawful acts. In such cases, the chairman will first give the member in question the opportunity to withdraw the utterances in question. If he does so, they are not erased from the record but are marked there as 'dead'. Whether or not an utterance is withdrawn, the chairman may still decide to erase the relevant words from the record, but he should do so after consultation with the present members of the records committee. ${ }^{188}$ If a member refuses to withdraw certain utterances when asked to do so, continues making such utterances, or continuously departs from the subject of the debate, the chairman may order that member to stop speaking. As an ultimate measure, the chairman of either chamber may expel a member who behaves inappropriately from the meeting altogether, in which case that member has to leave the parliamentary building. Until recently, the chambers could decide to extend such an expulsion up to a period of one month, but this possibility has now been abolished for both chambers. ${ }^{189}$

Finally, the chairman of the Second Chamber also has the power to act against inappropriate written utterances and prevent their publication: Article 53 of the Rules of Procedure of the Second Chamber provides that the chairman may disregard documents which are unsigned, incomprehensible or insulting'. The Rules of Procedure of the First Chamber do not contain a corresponding provision, but since the chairman is generally responsible for the conduct of the chamber's business, a similar power may be assumed there also.

When considering the disciplinary powers of the parliamentary chambers in the context of parliamentary immunity, two things should be noted. First, the disciplinary measures which the chairman has at his disposal can only avoid and prevent damage to a certain extent - it is easy to conceive of situations in which

186 See Arts. 58-62, Rules of Procedure of the Second Chamber and Arts. 94-98, Rules of Procedure of the First Chamber.

$187 \quad$ Franssen and Van Schagen 1990, p. 69.

188 Franssen and Van Schagen 1990, p. 70. Cancellation does not, however, necessarily prevent the publication of such utterances. Withdrawn utterances do not appear on the official record, but the media is not obliged to abstain from publishing them. Cf. Bovend'Eert and Kummeling 2010, p. 149.

189 Bovend'Eert and Kummeling 2010, p. 150; see also Handelingen Tweede Kamer 1992-1993, No. 22590, 5, p. 69. 
considerable harm can be done by an utterance in parliament: think, for instance, of defamation or betrayal of secrets. By the time that the member in question is admonished by the chairman or ordered to stop speaking, the damage is already done, regardless of whether or not he withdraws the relevant words. Moreover, the chairman is not always able to discern whether a certain utterance is defamatory or contains confidential information.

Second, the disciplinary powers of the Chambers are not a means through which injured persons could seek legal recourse, for instance by way of a petition to the speaker. They serve the exclusive goal of maintaining order in the StatesGeneral; the Rules of Procedure of the two chambers make no provision for retribution (or compensation). Since the disciplinary powers of the chairman do not extend to retroactive punishment, they cannot be equated to the application of regular criminal law, or be seen as a substitute for it. This differentiates the Dutch States-General from Parliament in the United Kingdom, where both Houses are (in theory!) equipped with all the powers of an ordinary court of law.

\subsection{The Immunity Dimension of Article 119 of the Constitution}

The members of the States-General, the ministers and the secretaries of state are tried for crimes committed in these capacities before the Supreme Court, also after having left office. The order to prosecute is given by royal decree or by a decision of the Second Chamber.

This provision, which prescribes a special procedure for crimes committed by the designated persons in the exercise of their office or mandate, is highly interesting in the context of parliamentary immunity. The historical analysis of the development of parliamentary immunity conducted in this chapter and, in particular, the 'swap' of non-accountability for inviolability in the grand constitutional revision of 1848, show that the origins of the current Article 119 are indeed to be found in the system of inviolability that once existed for both members of the government and parliamentarians in the Netherlands. It is therefore no surprise that Article 119 bears a certain resemblance to provisions which regulate the criminal liability of members of the government in the constitutions of other countries. ${ }^{190}$ The existence of such special provisions for members of government is normal in countries where government office is incompatible with the parliamentary mandate, as it means that members of government do not enjoy parliamentary immunity. However, these special provisions are not usually mutually applicable to parliamentarians (who already enjoy parliamentary immunity) but constitute a separate and often more limited immunity regime for the government alone. ${ }^{191}$ Article 119 of the Dutch Constitution does, however, apply to members of the States-General. Even though it does not provide for actual immunity, it must be considered in our examination of the Dutch parliamentary immunity regime.

See e.g. Art. 68-1 of the French constitution and Art. 103 of the Belgian constitution. For a comparison of a number of such provisions, see Hardt and Eliantonio 2011. 


\subsubsection{A Hypothetical Potential}

To what extent does Article 119 add a second layer of immunity to the protection offered by Article 71? At first glance it does not seem to add much, at least if measured by the standards of fully-fledged inviolability enjoyed by members of parliament in other countries.

First, prosecution under the procedure of Article 119 may be ordered by the Second Chamber of the States-General, but it does not necessarily require its consent, since the government may also give the order to prosecute by royal decree. It therefore seems as if Article 119 defies at least one of the purposes traditionally attributed to parliamentary immunity: to protect members of parliament from undue interference exercised by the executive. Article 119 sits uneasily with this traditional notion of parliamentary immunity.

Second, the material scope of Article 119 does not extend beyond such crimes specifically defined as ambtsmisdrijven (literally 'office crimes'), thus crimes committed in the exercise of the office or mandate. Criminal acts committed in the extra-professional sphere are therefore not covered. Accordingly, Article 119 is traditionally categorised as 'a certain guarantee against too easy interference by the judiciary ${ }^{\prime 192}$ rather than an actual immunity.

Nevertheless, in how far Article 119 of the Constitution de facto obstructs the course of criminal justice for members of the States-General, that is to say, in how far a certain immunity dimension can be read into it, remains to be assessed in a closer examination. Whether Article 119 has any practical 'immunity effect' critically depends on (a) the definition of an ambtsmisdrijf and (b) on whether the Second Chamber or the Government are inclined to call the prosecution into action, since such prosecution is not possible otherwise.

The second condition is clearly not fulfilled: to date, there has not been a single precedent of the application of the procedure of Article 119; the article has led a 'dormant' existence and has therefore been largely ignored in the literature on immunity. In practice, Article 119 does not play any role in the Dutch immunity system. However, as recently argued by Remco Nehmelman, the provision might bear an interesting hypothetical immunity potential. ${ }^{193}$ To trace Nehmelman's argumentation, we need to look at the statutory definition of crimes committed in office, ambtsmisdrijuen.

\subsubsection{Crimes Committed in Office (Ambtsmisdrijven)}

In section 2.4.1 of the present chapter, we discussed the Criminal Ministerial Accountability Act of 1855 (Wet op de strafrechtelijke ministeriële verantwoordelijkheid). According to this act, both the government and the Second Chamber of the StatesGeneral may order the prosecution of ministers for violation of the constitution or

and Elzinga 1990, p. 211

193 Nehmelman 2010b, p. 7-23. 
statute. While the government may give this order directly to the procuratorgeneral at the Supreme Court, the Second Chamber must first conduct an intricate examination of the alleged violation in a parliamentary enquiry committee. According to Article 483(1) of the Code of Criminal Procedure (Wetboek van strafvordering) this procedure remains in force. Pursuant to Article 483(2), the same procedure applies to the prosecution of the persons mentioned in Article 76 of the Judicial Organisation Act (Wet op de rechterlijke organisatie) for crimes committed in office (ambtsmisdrijven). The latter article reads as follows:

1. The Supreme Court takes cognisance in first and last instance of crimes committed in office by members of the States-General, the ministers and the secretaries of state.

2. For this purpose, crimes committed in office shall mean punishable acts committed under one of the aggravating circumstances described in Article 44 of the Criminal Code.

3. In the cases referred to in the first and second paragraph, the Supreme Court also takes cognisance of claims to compensation of costs and damage incurred by the injured party.

4. The cases referred to in the first and second paragraph are heard by the Supreme Court in a chamber of ten of its members. In case of a tied vote, it shall rule in favour of the defendant.

Thus, the term ambtsmisdrijf does not refer to one or more specific criminal acts. Rather, it refers to any criminal act performed under certain additional conditions defined in Article 44 of the Criminal Code, which reads as follows:

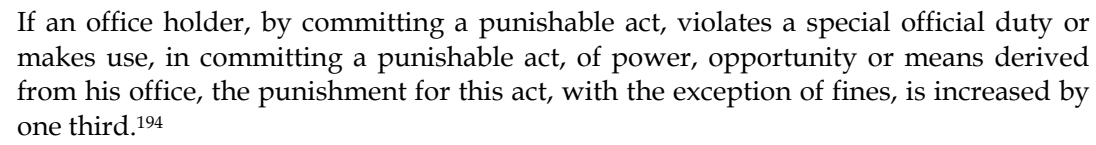
makes use, in committing a punishable act, of power, opportunity or means derived from his office, the punishment for this act, with the exception of fines, is increased by one third. ${ }^{194}$

Read in conjunction, Article 483 of the Code of Criminal Procedure, Article 76 of the Judicial Organisation Act and Article 44 of the Criminal Code present the following picture: where a minister, secretary of state or member of either Chamber of the States-General is alleged to have committed a criminal act - among which are crimes of utterance outside the scope of non-accountability - he will be tried in an ordinary court, unless the alleged criminal act has been committed (a) in violation of a special official duty, or (b) by making use of power, opportunity or means derived from his office or mandate. In such a case, the minister, secretary, or member will be tried in first and last instance by the Supreme Court, but only if his prosecution has been ordered by the government or the Second Chamber. In the latter case, a parliamentary enquiry procedure has to precede the indictment. 


\subsubsection{Does this Procedure Amount to Inviolability?}

As previously mentioned, the procedure outlined above has never been applied. Therefore, answering the question of whether it could potentially be read and applied as a form of inviolability for members of the States-General necessarily includes a large element of speculation. Clearly, if a criminal act committed by a member of the States-General, minister, or secretary of state were to be recognised as a crime committed in office under Article 44 of the Criminal Code, the procedure of Article 119 of the Constitution in conjunction with the Criminal Ministerial Accountability Act would have to be followed. Scenarios involving ordinary criminal acts, committed with the help of 'power, opportunity or means' derived from the parliamentary mandate, are conceivable. Given that, in such a case, the prosecution of the member in question could still simply be ordered by the government without the intervention of the Second Chamber, this would not, however, amount to actual inviolability. Nevertheless, the fact that a member could not be prosecuted upon an ordinary criminal complaint or upon the motion of the public prosecutor would provide a certain procedural guarantee, considering that the government would probably not give the order to prosecute a member of the States-General light-heartedly.

In his thought-provoking analysis, Nehmelman argues that the procedure of Article 119 could be of significance in dealing with criminal utterances of members of the States-General which are not covered by Article 71. In his view, this could concern, for instance, racist comments in the media or non-parliamentary cases of hate speech. While such speech acts would not violate any special official duty of the parliamentarian in question, he argues that they may well be committed with the use of 'opportunity or means' derived from the parliamentary mandate, since it is the mandate which puts a member of the States-General in a position to disseminate his views publicly. According to Nehmelman, a parliamentarian's access to the media and the media's attention to his views can thus be seen as an opportunity derived from the capacity of being a member of parliament. ${ }^{195}$ Nehmelman contends that this view is supported by case law of the Dutch Supreme Court, in which it was held (with regard to a civil servant) that a 'crime committed in office' does not require a material link between the tasks of the office and the criminal act. It suffices that the office provides the perpetrator with the opportunity to commit the criminal act. ${ }^{196}$

Still, it is doubtful whether Nehmelman's interpretation is sufficiently sustainable to hold up in court in cases relating to non-parliamentary utterances of members of the States-General. After all, it seems outright impossible to prove that the opportunity to make a public statement derives exclusively, or to a degree sufficient to merit a deviation from ordinary criminal procedure, from a person's public office or parliamentary mandate. Many public figures enjoy considerable media attention and have ample opportunity to disseminate their opinion on any

Nehmelman 2010b, p. 21

Nehmelman 2010b, p. 20; see also HR 8 December 1998, NJ 1999, 224. 
issue in the media without holding any office or mandate. Perhaps even more importantly, many public statements of elected politicians receive very little media attention where the media are of the opinion that they do not deserve any. In other words, not only is media attention equally available to persons without a public office or parliamentary mandate, it is also no automatism for persons who do hold such an office or mandate. This is too weak a basis for the categorisation of a public statement as an ambtsmisdrijf.

Nehmelman embarks on his analysis of Article 119 with the aim of establishing whether inviolability would, in principle, be possible in the Netherlands and whether it would fit the existing constitutional framework. He does so in light of the demand, voiced recently in public and scholarly debate, that politicians should enjoy a higher degree of freedom of speech beyond the parliamentary sphere and beyond the limits of Article 71 of the Constitution (see section 3.4 below).

It is easy to admit that such an extension of freedom of speech - and the creation of inviolability! - would be the result if, on the one hand, the procedure of Article 119 was actually applied in practice and if, on the other hand, it was modified in a certain way. For instance, if the consent of a chamber of the StatesGeneral was required and could not be circumvented by the government, this would technically equate Article 119 to a classical inviolability provision. ${ }^{197}$ Nevertheless, the implementation of this idea is highly unlikely, both with regard to the proposed interpretation of the criteria for ambtsmisdrijven and with regard to the chances of the necessary amendment to Article 119 of the Constitution actually being made. This is the case, first, because the idea of broadening freedom of speech for politicians (and parliamentarians in particular) by bringing crimes of utterance under the category of crimes in office entails a certain paradox: with the aim of creating a greater freedom of speech, criminal speech would be brought within the definition of Article 44 of the Criminal Code, which lists aggravating circumstances and prescribes a heavier sanction! Even though it is reasonable to assume that the procedural obstacles which the categorisation of an act as ambtsmisdrijf carries with it would decrease the risk of actual prosecution (and thus have a certain 'immunity effect'), trying to achieve a higher degree of freedom of speech through these means would appear to be an unsound legislative trick.

Second, one has to realise that a broad interpretation of 'power, opportunity or means derived from the office' (or mandate) would not only lead to higher obstacles for the prosecution of politicians for speech crimes, but also for any other criminal act potentially facilitated by the mandate. With a little imagination, possibilities for the abuse of the parliamentary mandate or ministerial office are abundant.

Lastly, the adjudication of the question of whether a criminal act has actually been committed with the help of 'power, opportunity or means derived from the office' - which would need to be answered in order to even decide the course of criminal procedure - would certainly be problematic. Where a criminal utterance is made, for instance, in a televised interview, it is comparatively easy to argue that 
the person in question has been interviewed specifically in his capacity of being a member of parliament. If, however, the allegedly criminal utterance is made in the form of a film like Wilders's Fitna, which a member of parliament produces privately or with the help of others, can the attention the film receives as a consequence of the prominence of that member really be interpreted as an 'opportunity' derived from the mandate? Probably not with sufficient certainty.

In conclusion, the following can be said about Article 119 of the Dutch Constitution: First, this article is in some respects similar to inviolability provisions which exist in other countries. This is because it is the constitutional remnant of the inviolability which existed in the Netherlands prior to 1848 and which declined after the introduction of non-accountability. With some interpretative effort, it could be construed as an addition to parliamentary immunity, but due to the government's right to order the prosecution of a member, minister, or secretary of state for a crime in office without the intervention of parliament, it does not actually constitute a form of inviolability. With considerably more interpretative effort and, above all, with the help of a constitutional amendment, Article 119 might be transformed into an inviolability provision. However, both the likelihood and the desirability of such an amendment are highly questionable.

\subsection{Wilders and Beyond: A Case for Broadening Immunity?}

In the Netherlands, as with many other states, parliamentary immunity as a constitutional institution has long led a rather quiet, inconspicuous existence. ${ }^{198}$ Only recently has it risen to a level of notoriety unheard of since the first half of the $20^{\text {th }}$ century, when the questionof whether immunity should be limited in order to exclude certain utterances of extremist and revolutionary parliamentarians was discussed. Today, parliamentary immunity is once again the object of debate, but this time, the question is the opposite: does an immunity system which only protects parliamentary debate do justice to modern forms of political discourse, or should it be broadened? In other words, should parliamentary immunity be replaced or supplemented by political immunity?

The issue of the adequacy of non-accountability ex Article 71 of the Constitution has its origin in the case of Geert Wilders, a political populist of the extreme right and member of the Second Chamber. On numerous occasions, Wilders had agitated against Islam and Muslim immigrants and pursued a political agenda with the aim of halting or limiting the immigration of non-western individuals into the Netherlands, as well as curtailing the practice of Islam. Among others, he had demanded a ban of the Qu'ran, which he compared to Hitler's Mein Kampf and referred to as 'that fascist book' ${ }^{199}$ In August 2007, he had released the film Fitna, the tenor of which is equally anti-Islamic. While Wilders has also represented his anti-Islamic stance in the Second Chamber, his most contentious utterances were made in public speeches, interviews and other publications outside

Nehmelman 2011, p. 355. Wilders 2007. 
parliament and did therefore not fall under Article 71. The question of how far a politician and member of the States-General may go in defending his views in public thus had to be answered.

\title{
3.4.1. The Prosecution of Geert Wilders
}

Initially, the Dutch prosecution service decided not to charge Wilders for his utterances. Although these utterances were potentially offensive, it was argued, they had to be understood as contributions to public political debate and were thus not punishable. However, following a number of complaints by private persons and interest groups, the Amsterdam Court of Appeals reviewed this decision. ${ }^{200}$ Most interesting for the ensuing debate on the necessary scope of freedom of speech for politicians was the Court's analysis of the argument according to which utterances made in the context of public debate justify a wider freedom and are therefore not punishable. The Court rejected this argument:

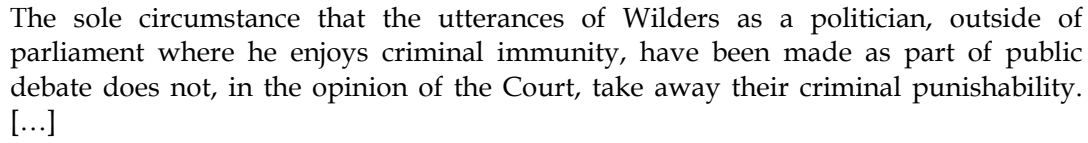

The sole circumstance that the utterances of Wilders as a politician, outside of parliament where he enjoys criminal immunity, have been made as part of public debate does not, in the opinion of the Court, take away their criminal punishability. $[\ldots]$

\begin{abstract}
Although the Court is well aware that a politician, also in extra-parliamentary debate, must enjoy as much freedom as possible in formulating and disseminating his political views, the Court is of the opinion that this freedom does not relieve the politician of his responsibility to make contributions to public debate which are acceptable to society.
\end{abstract}

\begin{abstract}
The assessment of the manner in which public debate is conducted in terms of content does not in itself belong to the tasks of the judiciary. This is different where a contribution to public debate is unnecessarily offensive for a group of believers by violating their religious dignity, while the contribution also incites to hatred, intolerance, enmity and discrimination. Then, the criminal law enters the picture. In the past, people, also politicians, have been convicted for less far-reaching utterance than those done by Wilders. ${ }^{201}$
\end{abstract}

With this conclusion, and considering that Article 10 of the ECHR allows certain justified exceptions to freedom of speech, the Court of Appeals ordered the prosecutor's office to charge Wilders for insult of a group of persons and incitement to hatred.

The trial was held in Amsterdam District Court, which subsequently acquitted Wilders of all charges and thereby followed the plea of the prosecutor. The acquittal was primarily based on the argument that the utterances in question were directed against Islam as an ideology, and not against the followers of that ideology; therefore, they did not insult Muslims as a group of persons, even though they might find Wilders' utterances offensive. On the basis of a similar argumentation, the Court dismissed the charge of incitement to hatred against Muslims. With

200 Hof Amsterdam, 21 January 2009, LJN: BH0496

$201 \quad$ Ibid., para. 12.1.4. 
regard to the alleged incitement to discrimination on the basis of religion - one of the contested utterances contained a demand that no Muslim immigrants be allowed into the country - the Court was of the opinion that, even though Wilders had definitely proposed to discriminate between Muslims and non-Muslims in immigration policy, this was not punishable in a contribution to public debate by a politician. ${ }^{202}$

\subsubsection{Parliamentary vs. Political Immunity}

The two court rulings in Re Wilders illustrate that the core legal issue in this and similar cases is actually not the scope of parliamentary immunity. Since the allegedly criminal utterances for which Wilders was prosecuted were made exclusively outside parliament, it was clear that Article 71 of the Constitution could not be used as a defence. Conversely, similar utterances which Wilders has repeatedly made in the Second Chamber were not the subject of litigation, since he would have undoubtedly been protected by non-accountability, as the Court of Appeals has explicitly recognised in its considerations (quoted above).

The material content of the immunity currently in place - with the possible exception of the hypothetical immunity value of Article 119 of the Constitution discussed earlier - is uncontested. Rather, the unresolved problem which we encounter in the Netherlands is whether politicians enjoy - or should enjoy - a wider freedom of speech in public debate than other citizens due to their political role and their task of representing (a part of) the public opinion. It is in light of this that we should read demands for a broadening of the scope of immunity to cover contributions to public debate outside parliament. Before we address such demands, however, it is useful to make a brief inventory of the current state of freedom of speech for politicians.

\subsubsection{Freedom of Speech for Politicians in Public Political Debate}

Do Dutch politicians enjoy a higher degree of freedom of speech in public debate than ordinary citizens? A definitive answer to this question is difficult to find in Dutch case law. Nieuwenhuis, who has reviewed this body of case law comprehensively in an article of 2010,203 finds that the results are inconclusive.

At times, Dutch judges seem to tend towards a positive answer: in one relatively recent case, an accountant sued a member of a municipal council for defamation after the latter had made wrongful comments about him in political statements contained in a letter to the municipal executive. The council member had published that letter on the internet and therefore did not enjoy non-accountability. The court was still confronted with a conflict between the right to freedom of speech and the right to a good name and reputation. It considered that: 
'In European and Dutch case law it is generally accepted that the freedom of opinion, certainly that of a politician, usually weighs heavier than the right to protection of a person's honour and good name, even if this rule is not absolute'. [Emphasis added] ${ }^{204}$

In this particular case, the court honoured the rule thus formulated and ruled in favour of the defendant council member.

In the same ruling in which the Amsterdam Court of Appeals ordered the prosecution of Geert Wilders, the court found that 'a politician, also in extraparliamentary debate, must enjoy as much freedom as possible in formulating and disseminating his political views'. However, in that case it attached a greater weight to the interest of the persons whose right Wilders had allegedly violated and added that this freedom does not relieve the politician of his responsibility to make contributions to public debate which are acceptable to society'. ${ }^{205}$

Yet, in the case of another Dutch right-wing politician and member of the Second Chamber, Hans Janmaat, who had publicly announced (outside parliament) that the aim of his party was to 'abolish multicultural society', the Dutch Supreme Court stated that politicians speaking in public were under an obligation of 'restraint and consideration', particularly in light of the influence which their statements have on public opinion. ${ }^{206}$ In this sense, a person's capacity as a member of parliament can even be interpreted as an extra burden on freedom of speech, since the public attention and impact which public utterances of parliamentarians are likely to have result in an additional duty of restraint, as we have already observed in our analysis on ECtHR case law on the issue of the freedom of expression of parliamentarians. In particular, the case Féret $v$. Belgium ${ }^{207}$ has illustrated that the ECtHR recognises this duty of restraint, especially with regard to racist statements and hate speech. On the other hand, Nieuwenhuis cites rulings of lower courts in which the judges found that politicians, especially members of parliament, must be able to voice their views with the necessary force, ${ }^{208}$ in particular during election campaigns. ${ }^{209}$

It is clear that a 'right' to poignancy and force in public political statements is hard to reconcile with a duty of restraint. As a result, we must find Dutch case law somewhat ambiguous as to the precise scope of freedom of speech of politicians in public debate.

This ambiguity is also owed to the influence of ECtHR case law, which is directly applicable in the Netherlands' monist legal system and which Dutch national courts frequently use as a point of orientation. We have already seen in Chapter II that the body of case law from Strasbourg does not provide an accurate, clear delimitation of the degree of freedom of speech enjoyed by politicians outside

Hof Amsterdam, 21 July 2008, LJN: BD9027.

Hof Amsterdam, 21 January 2009, LJN: BH0496, para. 12.1.4.

HR 18 May 1999, NJ 1999, 634.

Féret v. Belgium, ECHR 16 July 2009, Appl. No. 15615/07.

Rechtbank den Haag, 7 April 2008, LJN: BC8732.

Hof Amsterdam, 10 March 1983, NJ 1984, 352. 
parliament. It is useful to recall the most important results of this body of case law. On the one hand, the ECtHR found, in Castells v. Spain, that:

\begin{abstract}
'[w]hile freedom of expression is important for everybody, it is especially so for an elected representative of the people. He represents his electorate, draws attention to their preoccupations and defends their interests. Accordingly, interferences with the freedom of expression of an opposition member of parliament [...] call for the closest scrutiny on the part of the Court'. 210
\end{abstract}

On the other hand, the ECtHR seems more ready to accept an interference with a politician's freedom of expression - for example, to accept his criminal conviction where his utterances do not directly relate to political matters (see, for example, Keller v. Hungary). ${ }^{211}$ This does not mean, however, that statements which are political in nature or relate to matters of public interest are generally protected. In Öllinger v. Austria ${ }^{212}$ the ECtHR found that the statements which a parliamentarian had made but was unable to prove were in fact important for societal debate. Nevertheless, the Court held that the limitation of the member's freedom of expression imposed by the Austrian court was not disproportional. Finally, Féret $v$. Belgium has made it amply clear that the political nature or societal relevance of the content of an utterance does not automatically merit greater freedom of speech. Sensitive topics such as immigration and the integration of foreigners must, in particular, be handled with care, especially by politicians.

In conclusion, the case law of both Dutch national courts and the European Court of Human Rights results in a somewhat vague picture of the exact extent of the freedom of speech of politicians in public debate. It is clear, on the one hand, that the courts generally admit the special position of politicians as representatives of the people and recognise their enhanced need for freedom of expression. On the other hand, this special position does not rule out legitimate limitations of this freedom - it may even cause such limitations where politicians are assumed to have a special responsibility when speaking publicly. But whether a limitation is legitimate in a specific case, that is, whether a politician may be held legally liable for his utterances is hard to determine with certainty. One factor which certainly plays an important role is whether the utterances in question are of a political nature: if a public statement cannot be attributed to public political debate, it does not merit an enhanced freedom of expression. However, this criterion is hardly suitable for providing much clarity - after all, as Thomas Mann famously stated 'everything is politics'. And even if the courts are willing and able to apply a more refined definition of what falls within the category of 'contributions to public political debate', it is unlikely that this will simplify the adjudication of cases like that of Geert Wilders.

Castells v. Spain, ECHR 22 April 1992, Appl. No. 11798/85, para. 42.

Keller v. Hungary, ECHR 4 April 2006, Appl. No. 33352/02.

Öllinger v. Austria, ECHR 13 May 2004, Appl. No. 74245/01. 


\subsubsection{Does Parliamentary Immunity Offer a Solution?}

Even though the courts have generally acknowledged that politicians deserve and require a wide freedom of expression even when speaking outside parliament, the somewhat blurred picture of this freedom outlined above hinders the conclusion that politicians in the Netherlands enjoy special protection. Whilst in France and other countries the prosecution of parliamentarians (though not necessarily members of the government) for criminal acts committed outside the parliamentary sphere can be suspended at the behest of parliament where it deems this desirable, no such possibility exists in the Netherlands.

At the same time, political discourse no longer takes place exclusively in the plenary hall of parliament, but increasingly in the public media, where politicians have to disseminate and defend their views, proposals and political goals vis-à-vis their electorate. In addition, parliamentary debates, now often broadcast live on television or the internet, function as a platform for communication with the wider public, while actual political decisions are (still) taken in the backrooms of parliament, in the quarters of political parties or behind closed doors by the government. Under such changed circumstances, it is argued, maintaining the strict separation between what is said in and outside of the parliamentary meeting appears artificial and anachronistic.

Consequently, there has been a proposition to broaden the scope of parliamentary immunity so as to effect 'the absolute protection of the spoken word of members of the Chambers outside of parliament'. ${ }^{213}$ Peters has put forward some arguments in support of this demand. First, he argues that the nowadays artificial separation of parliamentary and extra-parliamentary political debate may create problems in the adjudication of allegedly criminal extra-parliamentary speech; what if, for instance, a parliamentarian makes a potentially discriminatory legislative proposal and is later asked for further elaboration on said proposal in an interview ${ }^{214}$ Second, he makes the teleological argument that, if parliamentary immunity has as its goal the protection of free political deliberation, and if such deliberation now increasingly takes place beyond the walls of the plenary hall, it would be logical to protect extra-parliamentary political speech as much as speech is protected in parliament. He adds that this protection should not discriminate between contributors to public debate with or without a parliamentary mandate but that it should cover any contribution, including non-politicians and the press. ${ }^{215}$ This would of course render trials like that against Geert Wilders impossible and replace them, as Peters hopes, with fierce but open public political debate.

Many Dutch commentators throughout the political spectrum have concluded, in the wake of the trial against Wilders, that the criminal courts are not the right forum to judge public utterances of politicians, ${ }^{216}$ and some have also joined Peters'

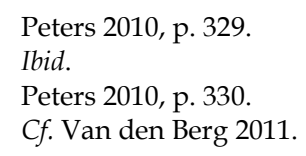


call for a substantial broadening of parliamentary non-accountability. ${ }^{217}$ In order to discuss such demands from a legal point of view, it is first necessary to separate the legal and political issues which are raised by the proposal to broaden nonaccountability. The main political question is whether absolute freedom of expression in public political debate is desirable or, respectively, whether and how the boundaries between the right to freedom of political expression and other rights need to be clarified in the law or redrawn along different lines. This question of desirability cannot, of course, be truly answered from a purely legal point of view. We can, however, explore the possibility and legal implications of broadening parliamentary non-accountability within the existing constitutional framework and the nature of the immunity which would result from such an operation.

Is it legally possible to expand the scope of parliamentary non-accountability so as to establish an absolute freedom of political expression for parliamentarians outside parliament? It clearly is not. First, the freedom of expression which members of the States-General enjoy in the parliamentary meeting is by no means absolute: they may neither speak whenever they like, nor, crucially, say what they like. Although Article 71 of the Constitution withdraws utterances in parliament from the application of criminal law, the parliamentary chambers themselves and their chairpersons in particular remain competent to sanction members for their utterances, according to the parliamentary Rules of Procedure. Even though it is true that little use is currently made of the chairman's power to sanction, ${ }^{218}$ the existence of this power reflects the logic of all parliamentary immunity: it is not meant to confer upon members a carte blanche for licentious speech, but to serve the separation of powers and to ensure parliamentary self-government. Outside parliament, the chairpersons of the parliamentary chambers are unable to maintain order and to sanction - and even if they were able to do so, this would be irreconcilable with the separation of powers. Thus, if Article 71 of the Constitution was to be amended to read 'what they have said in political debate' instead of 'what they have said in the in the meetings of the States-General or of committees thereof', this would clearly defy the institutional logic of parliamentary immunity. Moreover, it would certainly not be acceptable under the ECHR: the Court in Strasbourg has accepted parliamentary immunity as an exception to access to court (Article 6 ECHR) only as far as a protected act or utterance is narrowly connected to the parliamentary tasks of a member. ${ }^{219}$ In other words, an institutional link is required.

Since the extension of parliamentary non-accountability is thus not possible, we may ask ourselves whether it would be a feasible alternative to ensure absolute freedom of expression for all contributors to public political debate and not only for parliamentarians. For instance, a general constitutional right could be created to that effect, and an exception of political speech added to all crimes of utterance in the

217 E.g. F. Halsema, former leader of the Green/Left party in the Second Chamber. See 'Halsema: meer parlementaire onschendbaarheid", in De Volkskrant, 11 January 2011.

Peters 2010, p. 329.

219 See Chapter II. In Tsalkitzis v. Greece, the Court described its test as follows: 'la Cour recherchera si les actes incriminés étaient liés à l'exercice de fonctions parlementaires stricto sensu afin de conclure sur la proportionnalité ou non de la mesure mise en cause'. (para. 47). 
criminal code. This would create a new form of political immunity, quite independent of the institution of parliament.

However, would absolute freedom even of potentially discriminatory, antidemocratic or insulting political speech - and we may allow ourselves to question this desirability - solve any problems? It does not appear so. On the contrary, absolute political immunity would entail insurmountable conflicts of fundamental rights, since it would place freedom of speech above such rights as privacy and nondiscrimination, on the sole condition that an utterance is of a political nature or contributes to public debate. This way, the new immunity would first fail the strict test of the ECtHR if it were claimed by persons whose utterances can be attributed to the state, such as ministers speaking on behalf of the government. Without the possibility of justifying the immunity on the basis of the institutional needs of parliament and the separation of powers, it would violate Article 6 of the Convention.

Further, problems would not only arise in relation to the ECHR but also to other international obligations. For example, the Netherlands has ratified the International Convention on the Elimination of all Racial Discrimination (ICERD). As opposed to other states (such as Belgium), it has not made a reservation against (parts of) Article 4 of this Convention, which requires the state parties amongst others to impose a criminal sanction on '[...] all dissemination of ideas based on racial superiority or hatred, incitement to racial discrimination, as well as all acts of violence or incitement to such acts against any race or group of persons of another colour or ethnic origin [...]'. Absolute freedom of speech in political debate would prevent the criminal prosecution of racist utterances and thereby undoubtedly violate this provision.

Finally, even if a system of comprehensive political non-accountability were introduced, the courts would still face the almost impossible task of defining 'political speech' and to distinguish it, for instance, from non-political criminal hatespeech.

In conclusion, whether a broadening of freedom of speech - either that of politicians or that of all persons - is desirable is ultimately a decision which must be left to political discourse. However, the above clearly shows that neither the option of extending parliamentary non-accountability to wider public debate nor that of introducing a genuine political immunity is in fact legally feasible. This is a result, on the one hand, of the necessarily institutional character of parliamentary immunity and, on the other hand, of international obligations.

\section{Conclusion}

In the present chapter, we have tried to compose a comprehensive picture of the origins and the historical development of parliamentary immunity in the Netherlands as well as its current material state and recent debate within its context. In the introduction to this chapter, we asked a number of questions: is there any evidence for the hypothesis that the comparative narrowness and limitation of the 
Dutch immunity system finds its origin in a lack of historic conflict between parliament and the executive? What is the precise content, scope and meaning of the immunity provisions? Is parliamentary immunity in the Netherlands really as limited as it appears compared to the immunity systems of other countries, or does the system at least contain a potential for inviolability? And finally, how does the proposal to expand parliamentary non-accountability to political immunity in the wake of the Wilders case have to be understood and assessed from a legal point of view?

With regard to the first issue, it would be too much of an abbreviation of history to present the comparative lack of conflict as the only reason for the limited nature of Dutch parliamentary immunity, but it is certainly one of the reasons. As opposed to France and the United Kingdom, the struggle between the legislature and the executive which has led to the appearance of parliamentary immunity there did not take place - or at least not with comparable ferocity and impact - in the Netherlands, either during the Republic of the United Netherlands and the Batavian Republic or during the Kingdom of the $19^{\text {th }}$ century. Consequently, parliamentary immunity as a defensive device against a hostile executive has never become a hard-wired component of the constitutional structure of the Dutch state, even though it has existed in some form during all the different eras of the Dutch state. Parliamentary immunity has never been treated as a sacrosanct constitutional item akin to parliamentary privilege in the United Kingdom and which classical constitutional theory appears to identify in the French immunity system.

Another cause for the limited nature of immunity and the hesitation of the Dutch to adopt a broader system can be found in Dutch constitutional culture. The Dutch image of parliamentary immunity has historically ranged between that of an institution which can be useful if handled with care and that of an objectionable and potentially dangerous privilege, with the capacity to facilitate licentious speech and other moral transgressions. This is illustrated in constitutional practice by the alternation of non-accountability and inviolability during the $19^{\text {th }}$ century - while French theory traditionally sees both layers of immunity as necessarily complementary, the drafters of the Dutch constitutions apparently considered their coexistence excessive. Only non-accountability has taken root as an important element of parliamentarianism in the Netherlands: even in times of increasing political radicalism which threatened the legal order as a whole, the constitutional legislator could not agree on plans to adopt exemptions from non-accountability or to otherwise punish members of parliament and other representative bodies who promoted a revolutionary agenda. After the demise of Nazism, any such amendments were deemed to be unnecessary.

What is the precise scope of parliamentary immunity in the Netherlands and how limited is it in reality? Essentially, the Dutch immunity system is limited to non-accountability for words spoken in, or documents submitted to, the two chambers or their committees. It applies to members of the two chambers, ministers, secretaries of state and other persons taking part in parliamentary deliberations. Article 71 prescribes a number of conditions for the application of nonaccountability which have to be interpreted restrictively: oral utterances are only 
protected if they are made by an eligible person at the place of the meeting and while the meeting is ongoing. Written utterances are protected if they are submitted by an eligible person to (a body of) parliament or published by it in the form of an official publication. Private publications of any kind, even if they are literal repetitions or copies of parliamentary speech or documents, are not covered. However, where non-accountability does apply, there are no limitations with regard to the content of oral or written utterances. In particular, it is not necessary for nonaccountability that the utterances in question relate to the subject currently debated in the meeting. 'Persons taking part in deliberations' are only persons who actually participate in parliamentary discussion. Persons who merely provide information, such as witnesses or experts, never enjoy non-accountability, regardless of whether their input has been commissioned by parliament or whether they submit materials on their own motion. There is also no 'derivative immunity': if experts or researchers contribute material to an official report of a parliamentary committee in their own name, they remain fully liable for the content of that material. Nevertheless, where a person is heard as a witness or expert by a parliamentary enquiry committee, he cannot be liable. This follows from Article 30 of the Parliamentary Enquiry Act (Wet op de parlementaire enquête).

There is no inviolability in the Dutch immunity system. It has been argued that it would be possible to classify certain punishable acts and, in particular, utterances of parliamentarians, ministers or secretaries of state as crimes committed in office (ambtsmisdrijven) and thereby bring them within the range of Article 119 of the Constitution. However, this does not seem to be a realistic option. In order to qualify as an ambtsmisdrijf, it would have to be established that the crime has been committed by making use of power, opportunity or means derived from the office or mandate. Especially with regard to criminal utterances published in the media, it is inconceivable how it could be asserted with sufficient certainty that the attention of the media, and access to it, was actually derived from the office or mandate. Further, the procedure of Article 119 has never been applied and the article is regarded as a 'dormant' provision. Hence, even if it were legally realistic to do so, it is doubtful whether the hypothetical possibility to use the procedural obstacle created by it as a form of (or a substitute for) inviolability will ever be put to practice.

Outside parliament, members of the chambers - and politicians in general are not protected by any form of immunity. With reference to the ECHR and Strasbourg case law, the courts do sometimes recognise, however, that elected representatives of the people must enjoy as wide a freedom of expression as possible. Therefore, limitations of that right require the closest scrutiny and are not accepted easily; accordingly, the conviction of parliamentarians for crimes of utterance is unlikely, as illustrated by the case of Geert Wilders. Nonetheless, the precise position of politicians with regard to their freedom of expression in public debate is not entirely lucid. In particular, it is not clearly foreseeable when the courts will be inclined to distinguish between politicians and 'ordinary' citizens in the assessment of alleged crimes of utterance. In the wake of the trial of Geert Wilders, this has caused some to demand that the scope of parliamentary non- 
accountability be broadened to cover all contributions to public debate, whether in or outside parliament. We have shown that such a measure is legally impossible, since it fails to take into account the fact that parliamentary immunity is only justified - in light of national constitutional principles but also vis-à-vis the ECHR by its institutional character. Extra-parliamentary non-accountability would lack this necessary justificatory link with the institution of parliament.

The same would be true in case of the introduction of an even wider political immunity which covers members of parliament and other citizens alike and generally protects political speech and contributions to public debate. Such immunity would place freedom of speech above other fundamental rights and would therefore be manifestly at odds with the ECHR and other international instruments by which the Netherlands is bound, such as the International Convention on the Elimination of all Racial Discrimination (ICERD). It would also impose on the courts the difficult task of defining 'political' speech and thus deciding whether a certain utterance is covered by immunity. Since the courts would inevitably have to take this difficult decision, it is questionable whether the introduction of political immunity would even reach its aim of withdrawing political debate in its entirety from the application of (criminal) law. Even if political debate in the Netherlands should come to the conclusion that greater freedom of speech - for politicians or for all - is in principle desirable, our analysis shows that both broadening parliamentary non-accountability and introducing a form of political immunity would be highly problematic from a legal point of view.

Nevertheless, the debate about the desirability of a political immunity brings to light an interesting new facet of our hypothesis that immunity regimes have a tendency to evolve in a 'functional' direction. It is clear that, in the Netherlands, this functional approach would not require a reduction in the scope of the Dutch immunity system, since the latter does not feature inviolability. Instead, it is argued that the existing non-accountability ex Article 71 of the Constitution no longer does justice to the functions of a modern parliamentarian, whose task it is to address matters of general concern in public, not only in parliamentary debates. Thus, as in the Dutch case, the 'evolutionary pressure' on the system of parliamentary immunity demands an adaptation of this system to a functional reality. As opposed to the United Kingdom and France, however, this adaptation would result in an expansion of the very limited immunity which Dutch parliamentarians enjoy today. 

Chapter 6

\section{COMPARATIVE CONCLUSIONS}

This study has provided us with a thorough and comprehensive picture of the systems of parliamentary immunity of the UK, France and the Netherlands, as well as the European Parliament. Moreover, we have examined the approach of the European Court of Human Rights towards immunity in its case law. This analysis enables us to compare the different systems with the aim of establishing and explaining differences and commonalities as well as possible parallel trends and developments. This brings us to a better understanding of parliamentary immunity as a concept. In addition, we can now identify common norms and principles which apply to all (European) systems of parliamentary immunity. Together with national constitutional rules, they constitute a legal framework for the assessment of practical and political issues surrounding parliamentary immunity.

\section{Smallest Common Denominators}

Before we proceed to the findings of this study in more detail, we should recall a number of basic properties of parliamentary immunity which we have encountered in the three systems that have been the object of this study, and which also exist beyond (as evidenced by our analysis of the European dimension of parliamentary immunity) this.

First of all, there are two different categories of parliamentary immunity, which are usually referred to as non-accountability and inviolability. The former is often used as a synonym for freedom of speech in parliament. More accurately, it denotes immunity for activities which are an inherent part of the work of parliament. As such, non-accountability covers oral and written contributions to parliamentary debates and in committees, but also the parliamentary vote. The words 'in parliament' are slightly misleading, since they hint at a spatial notion of parliament - the building. This is wrong: for example, statements made at the Binnenhof, the building which accommodates the Dutch States-General, are only covered by non-accountability if made by a person entitled to the immunity and if made in the course of parliamentary deliberations. 
Although there are exceptions, non-accountability usually has two distinct properties which set it apart from inviolability: first, it is absolute. This means that it bars any form of legal action apart from internal measures of parliamentary discipline, and that it cannot be lifted or waived. Second, non-accountability usually applies perpetually, to the effect that legal action is barred for all time, even after the mandate of the parliamentarian in question has ended.

The term 'inviolability' denotes immunity which applies to extra-professional acts - acts which are not part of, or not connected closely enough, to parliamentary activity. The material scope of this immunity differs greatly between systems. In some, it is entirely absent. In others, it merely prohibits the arrest of members of parliament (usually with the exception of an arrest flagrante delicto). Sometimes, it prohibits all forms of legal action and even investigative measures against members of parliament.

Inviolability is usually limited in two ways: first, it can be lifted by parliament or one of its organs upon request. Second, it is of a temporary nature and ends with the end of the parliamentary mandate, so that the arrest, prosecution or other proceedings barred by inviolability can take place as soon as the person in question is no longer a member of parliament, also if these proceedings are related to criminal acts committed during the time of the mandate.

Across a large majority of legal systems in the world, including those examined in this study, there is a consensus that non-accountability is indispensable to parliamentarianism and, thereby, to a democratic state. Apart from very few exceptions, all states which have a (national) parliament do provide for nonaccountability - at least on paper. This is not true for inviolability, which is not ubiquitous, and usually absent in common law legal systems modelled after Westminster Parliament.

Along with the distinction between non-accountability and inviolability, a second basic property of parliamentary immunity which can be found in our three case studies and across Europe is that it is an institutional and not a personal privilege. Of course, members of parliament, as persons, are the immediate beneficiaries of immunity. They are the ones who may not be arrested or prosecuted. Nevertheless, it is a common feature of immunity systems that parliamentarians are deemed to enjoy immunity as a proxy for the institution to which they belong. It is parliament as an institution which deserves protection, not the member as a person.

\section{Lessons from History}

\subsection{A Summary of the Historical Origins of Parliamentary Immunity}

At first glance, the systems of parliamentary immunity of the United Kingdom (or, at the relevant time, England), France and the Netherlands emerged in very different historical contexts and through different processes. 
The first known appearance of the concept of privilege in England lies in the mists of the early medieval Anglo-Norman era which began after the Norman conquest in 1066: the members of the King's Council, or Curia Regis - the advisors of the King and members of the royal family - enjoyed the right of free passage and freedom from molestation under the king's peace (pax regis). This is the origin of the privilege of freedom from arrest, which therefore can be said to have existed well before parliament itself had reached a clear institutional form. Hence, freedom from arrest can be categorised as a 'pre-parliamentary privilege' rather than a parliamentary one. This gives it an exceptional character in comparison with the other British privileges and the immunities of the Dutch and French parliaments, which do not predate the modern institutional form of these assemblies but developed alongside them. The British privilege of freedom from arrest must be understood as a right of free passage for members of parliament, intended to guarantee their attendance of parliamentary meetings. It never covered arrest in criminal matters and therefore did not constitute an exception to the criminal law. Therefore, even though the privilege of freedom from arrest has never formally been repealed, it has been all but obsolete ever since the practice of imprisonment in civil matters (in particular, for debt) has been abolished.

The other privileges of the English parliament, most notably the privilege of freedom of speech and proceedings in Parliament, developed much later, as parliament gradually asserted its position and power vis-à-vis the monarch and developed from a mere advisory body into an institution which exercised de facto sovereignty. It is assumed that freedom of speech in the Commons has existed as a matter of vague tradition after the two Houses of Parliament had split in 1341. Only in the $16^{\text {th }}$ century did it begin to appear regularly in the Speaker's petition, by which the Commons sought to obtain their privileges from the monarch, but freedom of speech was not always granted and the king regularly tried to inhibit debate which did not please him (or her: Queen Elizabeth I made several attempts to interfere with free debate in the Commons). The privilege finally became legally solid with the adoption of the Bill of Rights of 1689 after the English Civil War, when Westminster Parliament had finally consolidated its dominant position vis-àvis the monarch.

Medieval France, before the emergence of the absolute monarchy, was a feudal state like England after the Norman conquest. It had a similar concept to the king's peace as existed there in the Anglo-Norman era. It included a right of free passage for members of the Curia Regis and the royal household. However, the constitutional and institutional development of France took a very different route, which did not lead to the emergence of an assertive parliament and limited powers of the monarch, but instead to absolutism. As a result, no real form of parliamentary immunity can be said to have existed in France prior to 1789. Members of the états généraux, a representative body which had evolved out of the ancient Curia Regis, were considered to be advisors of the King and as such enjoyed limited and temporary immunity from trial. Under absolutism, however, this immunity lacked the essential characteristic of protecting members of the états against the King himself, who stood above the law. 
The French immunity system did not evolve gradually but was created by the National Assembly in the early days of the French Revolution as an immediate reaction to the threat of violent reprisals by the King. With the King's soldiers reportedly lining up outside the assembly hall, the National Assembly adopted the first immunity decree on 23 June 1789, which established freedom of speech in parliament. It declared the prosecution, search, arrest or detention of an Assembly member on the basis of his proposition, opinion or speech in the Assembly an act of treason. Almost exactly a year later, on 26 June 1790, the National Assembly passed a second immunity decree which prohibited the arrest of a member without authorisation by the assembly, except flagrante delicto. Like the first decree, the second one was a reaction to circumstance: a member of the Assembly had been arrested for counter-revolutionary activity.

Whether the National Assembly actually intended to create two different forms of immunity or whether the second decree was merely intended to clarify the meaning of the first is open to debate. In effect, however, the two decrees created a two-tier immunity system: a first layer of immunity protected the members of the National Assembly from any form of legal action based on their utterances in the Assembly (non-accountability), while a second layer prohibited their arrest for any reason, unless with prior authorisation by the Assembly. Even though French constitutional history has been extremely volatile since the Revolution - since 1789, France has danced a 'waltz' of 13 to 15 constitutions, depending on how one defines the term. This two-tier system has remained the model of the French immunity regime until today and is clearly recognisable in Article 26 of the current French Constitution.

In the Netherlands, the first historical antecedents of parliamentary immunity can be found in two acts of the provincial States of Holland during the Dutch Republic. In 1588, following an incident in which the delegate of one city had been detained in another, the States of Holland adopted the acte van vrijwaring (act of guarantee) which granted the deputies of the cities of Holland the right of free passage (freedom from arrest) on their way to and from the meetings of the States. Nearly one century later, during one of the two periods of stadholderless government, the States of Holland passed the acte van indemniteit (act of indemnity) which provided that a member or his heirs should be compensated if they would suffer damages by reason of their political stance against the return of the stadholder. These two acts must not be understood as forming a cohesive immunity regime. Rather, they were both passed as immediate reactions to actual events or perceived future threats.

It is difficult to equate the provincial States and the States-General of the republican era with a parliament in the modern sense of the term. Both institutions exercised legislative as well as executive functions and were not confronted with a competing monarchical government. Hence, the immunity acts of the States of Holland did not aim to preserve the Assembly's power or independence which was already secure. Rather, the first act was meant to secure the attendance of the members of the States, while the second act was intended to protect the members of the assembly from their own successors, should the political mood swing back in favour of stadholder government. 
During the 'French period' (1795-1814) - the time of the Batavian Republic, the satellite Kingdom of Holland and the French annexation - the entire Dutch state was modelled after that of the French hegemonial power. This entailed, first, the transplantation of the extremely elaborate immunity system of the French Constitution of year III into the Dutch constitutional order and, later, the complete abolition of parliamentary immunity after Napoleon had taken power in France. After the re-establishment of the Dutch monarchy, the Netherlands first adopted a system of inviolability, however without explicitly recognising freedom of speech in parliament. The Constitution of 1848, which is the basis of the modern constitution, essentially abolished inviolability (apart from a marginal rest) and put absolute freedom of speech in parliament in its place.

\subsection{Freedom of Speech as the Epitome of Parliamentarianism}

The above juxtaposition of the origins of immunity shows that it is hardly possible to speak comprehensively of the emergence of immunity systems: freedom from arrest and freedom of speech made their first appearances separately. At least in England and France, the right of free passage for members of the medieval curiae existed centuries before free speech became an issue. ${ }^{1}$ However, it would be an anachronism to treat this right as a form of parliamentary immunity, of which it became a part much later. In this respect, it is more interesting to look at freedom of speech. The respective time at which this form of immunity appeared reveals its close connection with the institutional evolution of parliaments, their self-image and the circumstances in which they operated. Freedom of speech was only asserted once parliaments or their members found themselves under threat in relation to their political opinion. In England, this was the case as soon as parliament became more than a mere advisory body. After the feudal lords had secured Magna Carta from the King, and certainly after the Commons had become a separate House, Parliament had begun to emancipate itself from its limited advisory role. As a result, it regularly found itself in opposition to the King - a potentially lifethreatening situation, as early case law proves.

In our examination of the French immunity system, we have described how the immunity decree of 23 June 1789 was an attempt to protect the members of the National Assembly from reprisals by the King. Under absolutism, the prerevolutionary états généraux still functioned as an advisory or auxiliary organ; they posed no threat to the monarch, who was free to ignore the advice of the états - or not to convene them at all. After the Third Estate had declared itself the National Assembly, this new body stood in open opposition to the King - it had assumed the capacity to form a will on behalf of the nation and thus rejected both the concept of absolutism and that of an imperative mandate. This new position necessitated free speech in the National Assembly, both in terms of the Assembly's self-conception

The same was probably true in all medieval feudal states, thus also in the Netherlands. Since the Netherlands did not exist as a political entity at the time, the the pre-republican period was left out of consideration for the analysis of the history of Dutch parliamentary immunity. 
and on a more mundane, practical level, where the members of the Assembly had to fear physical reprisals from the King. Hence, despite all differences as regards the point in time and the speed at which freedom of speech in parliament emerged in England and in France, the two factors which caused its occurrence are the same: a shift in parliamentary self-conception from a mere advisory body to an independent organ of state in potential opposition to the king and, as a result thereof, the factual necessity for protection.

Even though the Dutch situation is more complicated, the pattern is similar: the Act on indemnity was geared specifically to indemnify members of the States of Holland who might suffer damage by reason of their opposition to the stadholder government. The Act only related to utterances that displayed an anti-stadholder attitude - apparently, other utterances were not deemed dangerous. The fact that freedom of speech during the Dutch Republic remained limited to this rather incidental act instead of developing into a permanent and more comprehensive immunity is certainly owed to the absence of a potentially hostile organ - such as a monarch - competing with the States for supreme power. That non-accountability remained - at least formally - absent from the Dutch Constitution after the end of the French period, and the establishment of the Principality and Kingdom of the Netherlands (1814 and 1815) also fits this picture. As the historian van Caenegem has put it, the Kingdom of William I was governed under a system of 'enlightened absolutism', covered by 'a thin parliamentary veneer'. The Members of the upper chamber of the States-General were appointed by the King, those of the lower chamber elected under a system which almost guaranteed a continuous royalist majority. It is easily conceivable that, under these conditions, the States-General neither bred the assertive and independent self-conception which we have identified as a pre-requisite for the emergence of a system of non-accountability, nor produced the situation of factual danger which had necessitated the insistence on freedom of speech in late medieval England and revolutionary France.

As a matter of historical fact it seems trite that freedom of expression in parliament is only needed, asserted and granted when controversial parliamentary debate actually takes place. However, the emergence of non-accountability in England, France and the Netherlands which we have examined in this book can also be read, conversely, as compelling historical evidence that controversial parliamentary debate requires absolute freedom of expression. It is therefore true that free speech is the epitome of parliamentarianism. Today, this is rightfully accepted as an axiomatic justification of non-accountability, even where it constitutes a limitation of the rights of third parties.

\subsection{Inviolability as a Secondary Immunity}

The history of parliamentary immunity in all three countries that have been studied shows that non-accountability has played an important part in the development of modern parliamentarianism. It was used to secure free speech in parliament, which is universally accepted as a logical prerequisite for the exercise of the constitutional tasks of a modern parliament - legislation, representation of the people and, as the 
case may be, control of the government. Hence, non-accountability rules are a ubiquitous feature of national constitutional law. Freedom of parliamentary debate appears to constitute a 'minimum immunity', a smallest common denominator among European immunity systems. In short, non-accountability is indispensable. This is not the case for inviolability, the extra-professional immunity which protects members of parliament from arrest - and sometimes from criminal prosecution or even civil legal action - on the basis of their acts outside the immediate context of the parliamentary mandate. What distinguishes inviolability from non-accountability is the lack of a material link between parliament as an institution and the act for which a member is to be arrested, prosecuted, or sued.

Two things can be learned from circumstantial historical evidence with regard to inviolability. First, viewed from a comparative angle this extra-professional immunity has never been as entrenched in national immunity regimes as nonaccountability has. It is a feature of the French or continental tradition of parliamentary immunity and therefore has found its way into many immunity systems in Europe. But even among systems of the continental legal tradition it is not ubiquitous - apparently, parliaments were well able to flourish without it.

Second, when we juxtapose developments in the British, French and Dutch systems of parliamentary immunity over the last 150 years, we can observe that inviolability is generally on the decline: in the United Kingdom, the privilege of freedom from arrest never prevented the application of the criminal law. However, in the $19^{\text {th }}$ century, when imprisonment in civil matters was still possible, this privilege certainly had an inviolability effect in that it rendered parliamentarians immune from legal action for matters entirely unrelated to their parliamentary mandate. While this inviolability was not abolished by an amendment of the privilege itself, but rather marginalised by ending the practice of imprisonment in civil matters, this has nevertheless had the practical effect of bringing an end to inviolability in the Westminster system of privileges.

In the Netherlands, the inviolability that existed in the first half of the $19^{\text {th }}$ century was traded against non-accountability in the Constitution of 1848. Since then, freedom of speech in parliament has been the only form of parliamentary immunity in the Netherlands. A constitutional remnant of the inviolability which existed in the Netherlands prior to 1848 can be found Article 119 of the Dutch Constitution, which provides for a special criminal procedure for crimes committed in office (ambtsmisdrijven). However, this procedure does not amount to immunity and has never been applied in practice.

In France, whose immunity system has always provided for greater inviolability than those of the two other countries studied, the demise of inviolability is most recent and most clearly visible. The Constitution of 1946 (the Fourth Republic) still provided for freedom from arrest, prosecution and investigative measures for the entire duration of the parliamentary mandate, unless authorised by the relevant chamber of parliament. The Constitution of 1958 maintained the material scope of inviolability, but limited its temporal scope to the parliamentary session. Members of parliament therefore only enjoyed inviolability for up to six months per year. Finally, the constitutional amendment of 1995 limited the material scope of inviolability to freedom from arrest, while the prosecution of 
members of parliament and investigative measures which did not affect their physical liberty have been allowed ever since.

Clearly, the abolition of inviolability in the UK and the Netherlands and its severe limitation in France occurred at very different points in times and for different reasons; they are unrelated to each other and too widely interspersed to speak of a common trend. They do, however, fit the general tendency towards a concept of immunity geared to a narrow and institutional understanding of the functions of the parliamentary mandate which one finds in all three national systems, and also on the European level (see section 4 below). In any event, the fact that inviolability is not only far less common than non-accountability, but that it is also - slowly - disappearing, allows us to conclude that it is indeed a secondary form of immunity which cannot be justified as easily as non-accountability.

\section{Theory and Parliamentary Immunity}

The historical comparison above has shown that the immediate reasons for which parliamentary immunity provisions had first been adopted were essentially circumstantial. Nevertheless, at least in the UK and France, constitutional theory has always played a very important part in their justification. In the following, we will first recapitulate the relationship between constitutional theory and parliamentary immunity and subsequently try to identify the effects of this relationship.

\subsection{The Justification of Parliamentary Immunity in Constitutional Theory}

For the United Kingdom, the starting point for understanding the relationship between parliamentary privilege and the constitutional system is the concept of Parliament as a court. As was explained at the beginning of our British case study, Parliament, the government and the courts all evolved gradually out of the ancient Curia Regis. The latter had previously exercised legislative, executive and judicial functions without distinction as to when it was doing what. It can be said that much of the constitutional structure of the United Kingdom is owed to the common ancestry which all main government institutions except the monarch himself share in what we can call a medieval institutional amoeba, the Curia Regis. This is true, in particular, for the closely interrelated concepts of parliamentary sovereignty and the High Court of Parliament: as Parliament is at the same time the institution which formally together with the monarch - produces statutory law and the highest court, its decisions (Acts of Parliament) bind all other courts, while it cannot be bound itself. Accordingly, the law of Parliament has been described as a legal system in its own right, entirely separate from the law of the land.

It is a logical consequence of this construction that Parliament is exclusively competent to govern its own affairs. This is the theoretical basis of British parliamentary privilege. Even though Parliament and the courts have always quarrelled over the precise extent of the area of exclusive cognisance and the question of what exactly counts as an internal affair of Parliament, the rough contours of parliamentary privilege can easily be deduced even without reference to 
Article 9 of the Bill of Rights 1689, or to case law. It is obvious that parliamentary debate itself forms the sacrosanct core of parliamentary activity and is thus immune. Conversely, criminal acts are not privileged, as they are unrelated to parliamentary business. Hence, members of Westminster Parliament do not enjoy inviolability. Finally, it follows from the fact that Parliament makes law, and dispenses justice only by collective acts, that parliamentary privilege belongs to Parliament as an institution and not to individual members.

French constitutionalists have encased the two-tier immunity system of nonaccountability and inviolability in an entirely different theoretical framework, which is not clearly substantiated by the text of the constitution. The starting point here is the doctrine of national sovereignty and representation which was discussed in Chapter IV. According to this doctrine, sovereignty belongs to the abstract, indivisible and eternal nation. The nation itself cannot exercise sovereignty and form a will of its own. Meanwhile, the actual, living people are able to form a will but cannot exercise sovereignty because this would mean to single out one component of the nation, which, however, is by definition 'indivisible'. It is at this point that the classical dogma of national sovereignty most clearly contrasts with the text of the constitution of the Fifth Republic, which states in Article 3 that 'national sovereignty belongs to the people' - an impossible thought under the theoretical framework devised by Carré de Malberg. Since neither the abstract nation nor the people can exercise sovereignty, national will-formation must take place in parliament, which is composed of members equipped with a representative mandate. In classical French constitutional theory, representation has a specific meaning: the mandate of a true representative is entirely free; he cannot be bound by instructions (which would amount to an imperative mandate). It follows that the representative decides autonomously in lieu of the mandate-giver. In order to facilitate representation, parliament must be absolutely independent. Traditionally, it has therefore been held that parliamentary immunity serves the purpose of securing this independence and that both non-accountability and inviolability are necessary to achieve it. This view is based on the argument that absolute freedom of speech in parliament is only meaningful if parliamentarians cannot otherwise be influenced (for example by the threat of instrumental criminal prosecution for unrelated matters) or even prevented from attending parliament by being arrested. However, we have seen in Chapter IV that recent doctrine - in particular the work of Guérin-Bargues - has called for an augmentation of the justification of inviolability by more practical reasons. While the theoretical framework as such has so far not been rebutted, this demand reflects the status of inviolability as a 'secondary' immunity which is harder to justify than non-accountability. The claim that freedom of speech is meaningless if not accompanied by further-reaching inviolability seems tempting, but it cannot be upheld on the basis of theoretical considerations alone. Other arguments, such as the lack of independence of the public prosecution service from the executive, are probably more compelling. 
In the Netherlands, parliamentary immunity is not supported by a similarly elaborate theoretical scaffold and has, as far as we can see, never been subject to much theoretical debate. This can perhaps be attributed to the fact that, since the beginning of the modern Dutch state in 1814, and certainly since its 'structural completion' in 1848, the existence and power of parliament itself did not have to be defended or justified. As we have seen in Chapter V, parliamentary immunity has led a quiet, almost dormant existence since it became an element of the Dutch Constitution. It can only be guessed that the lack of an existential struggle at the beginning of Dutch parliamentarianism was also the reason why both the StatesGeneral itself and Dutch legal authors have traditionally shown little enthusiasm for broad parliamentary immunity. Perhaps most importantly, there is but very little in the very limited Dutch immunity system which requires extensive justification.

\subsection{Constitutional Theory has a Conservative Effect}

What does the above teach us about the significance of constitutional theory in relation to parliamentary immunity? The most essential lesson to be learned from a juxtaposition of the theoretical constructions which have been invoked in support of British parliamentary privilege and the French immunity system is that they have a significant conservative effect. In the case of France, Guérin-Bargues has pointed out that the classical concept of representation (and, by implication, of national sovereignty) after Carré de Malberg has long dominated all doctrinal thinking about parliamentary immunity. This had the effect that a justification based on abstract concepts and legal fictions has been given preference over a practical reassessment of the necessity of inviolability. This is particularly dissatisfactory because the doctrine of national sovereignty is not only a highly abstract concept; it is not even supported by the text of the current French Constitution, nor by constitutional practice. Based on our comparative findings which do not support a vital necessity of inviolability for the proper functioning of a parliament, inviolability does indeed stand on much weaker justificatory ground than non-accountability.

In the case of the United Kingdom, a similar conservative effect can be seen in case law prior to Pepper $v$. Hart (1993), where it was decided that the courts may use parliamentary proceedings in order to establish the intention of the legislator. Even though the exact borderline between the area of Parliament's exclusive cognisance and the law of the lands have at times been slightly shifted, the courts had for a very long time been hesitant to create such inroads into the territory of the High Court of Parliament, even where this would clearly have appeared reasonable on the basis of a purely factual assessment, unaffected by abstract doctrinal considerations. For example, without a rather dogmatic, very strict notion of exclusive cognisance, the case of $R v$. Graham-Campbell ex parte Herbert (1935) would in all likelihood have been decided differently: in Graham-Campbell it was held that the sale of liquor without a licence in the House of Commons bar constituted an internal matter of Parliament and could thus not be reviewed by the courts. 
Both in the UK and in France, these conservative effects of a traditional doctrinal foundation of parliamentary immunity are only slowly and gradually permeated by practical concerns, not least under pressure by public opinion. This could be observed in the wake of the British parliamentary expenses scandal of 2009. The subsequent Supreme Court judgment in $R v$. Chaytor and the government's resolution to put parliamentary privilege on a clear statutory basis in the near future mark the gradual but steady departure from traditional concepts of parliamentary privilege.

\section{The State of Material Immunity and Developments}

\subsection{Parliamentary Immunity in the UK, France and the Netherlands: Material Similarities and Differences}

\subsubsection{Non-accountability}

In all three systems examined in this study, the material function of parliamentary immunity is essentially identical. Its purpose is to protect parliament from undue external influence and to facilitate the exercise of its constitutional tasks. In accordance with this identical purpose, all three systems have many essential aspects in common.

They share the ubiquitous common denominator of most immunity systems in the world: freedom of speech in parliament. In France and the Netherlands, this takes the form of non-accountability for written and oral utterances in parliamentary debate (including in committees) and the parliamentary vote. In the United Kingdom, freedom of speech falls under the privilege established by Article 9 of the Bill of Rights 1689, which protects 'proceedings in Parliament' and thus has a similar effect. In all three systems, the protection of freedom of speech is generally absolute and perpetual and, unlike German non-accountability which does not cover defamatory insults, none of the three provides for any exception with regard to the content of speech in parliament, even though the French National Assembly has recognised a certain devoir de réserve, or duty of restraint, which its members have to observe in their parliamentary utterances.

Even though the basic characteristics of non-accountability are the same in all three systems, some of its aspects differ between the three systems. A first difference can be observed in its personal scope. In the French system, non-accountability is strictly limited to members of parliament. It excludes other persons who might speak in parliament but are not members. Ministers, for instance, are therefore not covered by non-accountability; their office is incompatible with the parliamentary mandate (however, the criminal liability of members of the French government is subject to a separate set of constitutional rules). 
In the Netherlands, non-accountability also applies to members of the government and to other persons who take part in parliamentary deliberations, but not, for instance, to persons who are merely heard as a witness in a parliamentary committee. ${ }^{2}$ In the UK, parliamentary privilege ex Article 9 of the Bill of Rights 1689 protects 'proceedings in Parliament'. This makes a difference as regards the personal scope of non-accountability, since the decisive criterion is not a personal but a material one: it does not matter whether a person making a statement is a member of parliament, but whether the statement has been made as part of parliamentary proceedings. Accordingly, any person who takes part in such proceedings may be covered by privilege. As opposed to the Netherlands, this may, for instance, include witnesses.

A second set of differences can be found in the material scope of nonaccountability. The relevant provision in Article 26(1) of the French Constitution and its British counterpart in Article 9 of the Bill of Rights both reach slightly beyond utterances in parliamentary debate. French non-accountability extends to opinions expressed in the exercise of a member's functions. Utterances outside of an actual debate may be thus be covered by non-accountability, for instance where a member expresses an opinion on a parliamentary mission (but not, according to case law, on a government-sponsored mission). It should be noted, however, that the phrase 'within the exercise of his functions' has been given an even more restrictive interpretation in French case law than it has received from the CJEU, which has interpreted the identical provision in Article 8 of Protocol no. 7 to the Treaties as meaning that the opinion expressed should have a 'clear and obvious connection' with the member's parliamentary work. The British phrase 'proceedings in Parliament' has never been fully defined. It has been interpreted narrowly, most recently in $R v$. Chaytor, but nevertheless proceedings probably cover more than only parliamentary debate and internal documents. For instance, letters of complaint which a parliamentarian had written to a non-parliamentary institution on behalf of his constituents have been held to be proceedings in Parliament. Finally, the material scope of the Dutch non-accountability provision in Article 71 of the Constitution is the narrowest of the three. Only oral utterances made during the parliamentary meeting or documents submitted to it are covered.

Third, French and Dutch non-accountability applies absolutely and cannot be lifted by parliament or renounced by an individual member. Section 13 of the British Defamation Act 1996, however, has created an exception to the absolute nature of non-accountability. It offers individual members of Parliament the possibility of a waiver of privilege to allow parliamentary proceedings to be taken into account in a defamation suit.

Finally, an important difference exists between the British privilege of freedom of speech and non-accountability in France and the Netherlands concerning the type of legal action which is barred by non-accountability. While non-accountability in France and the Netherlands merely prohibits legal action against a parliamentarian

2 However, witnesses in parliamentary inquiry procedures are protected from liability under the provisions of the parliamentary inquiry act (Wet op de parlementaire enquête). 
based on his utterances in parliament, British proceedings may not be 'impeached or questioned'. Before the House of Lords decided Pepper v. Hart in 1993, this was interpreted as a general prohibition of any reference to parliamentary proceedings in court. In Pepper, the Lords held that consulting proceedings for the purposes of establishing the intended meaning of legislation was permissible. Any use which could amount to challenging proceedings remains prohibited; this also includes their use as evidence (because this might require the courts to question their truth). However, it is to be expected that future legislation on privilege will allow the use of parliamentary proceedings as evidence in criminal cases.

\subsubsection{Inviolability}

Of the three immunity systems we have examined, only the French one can be said to provide for inviolability. Article 26(2) of the French Constitution prohibits the arrest or other measures of a criminal or correctional nature which restrict the liberty of a member of parliament, save flagrante delicto. Deprivation of liberty for reasons other than criminal or correctional reasons (such as quarantine or detention for mental health reasons) remains possible. Further, the bureau of either chamber may lift a member's inviolability upon request. Pursuant to Article 26(2) the plenary Chambers have the right to demand the suspension of the detention or prosecution of a member for the duration of the parliamentary session. In comparison to the UK and the Netherlands, the French inviolability system appears to be quite broad, especially when considering that there is no requirement of any material link between the alleged criminal behaviour of a member and his parliamentary work. However, until relatively recently, French inviolability also barred criminal prosecution and measures of investigation, such as searches or wiretapping, against a parliamentarian. This has been abolished as a result of a the constitutional amendment of 1995, thus significantly reducing the scope of inviolability.

In the UK, as mentioned previously, freedom from civil arrest exists formally but arrests in civil matters have been abolished since the $1^{\text {th }}$ century. Hence, apart from very few and marginal exceptions, this privilege no longer has a practical effect.

As for the Netherlands, it has been argued that Article 119 of the Dutch Constitution bears a certain 'inviolability potential'. This article provides that members of the government and parliamentarians are to be tried by the Supreme Court for crimes committed in office; the order to prosecute must be given by the government or the Second Chamber of the States-General. The fact that the order to prosecute may not only be given by the Second Chamber but also by the executive distinguishes Article 119 from genuine inviolability provisions; after all, one of the objectives of parliamentary immunity is to protect parliaments from the executive. Further, the potential of Article 119 to have any substantial inviolability effect depends on the recognition of a criminal act as an ambtsmisdrijf (crime in office), which we have shown to be utterly unlikely. The term ambtsmisdrijf does not refer to one or more specific acts. Rather, it denotes any criminal act committed under the aggravating circumstances listed in Article 44 of the Criminal Code, thus either in 
violation of a special official duty or by making use of 'power, opportunity or means derived from the office' or mandate. It has been proposed that the procedure of Article 119 could be applied to criminal utterances - such as hate speech - by parliamentarians in the public media because the media attention which parliamentarians receive by virtue of their mandate can be interpreted as an 'opportunity' within the meaning of the Criminal Code. It must strongly be doubted whether this is indeed a possible use of Article 119 of the Constitution. After all, it is impossible to prove that a certain statement of a person, published through the media, has only become possible as a result of that person's capacity of being a member of parliament. Many public figures enjoy a degree of media attention which equals or exceeds that received by parliamentarians. Conversely, many public statements made by parliamentarians escape public attention, often due to a lack of media interest. In other words, media attention is not a natural attribute of the parliamentary mandate. Consequently, the fact that an MP is able to make a racist statement in a televised interview is not sufficient to categorise that statement as an ambtsmisdrijf. Article 119 is therefore not suited to create a form of inviolability for public utterances of parliamentarians. This is not to say that there is no possible use for Article 119 at all. Crimes by parliamentarians which would necessitate the application of Article 119 are not inconceivable; this would probably be the case, for instance, if a parliamentarian were to leak secret information which is available exclusively to members of a parliamentary committee. Crucially, the use of Article 119 as an inviolability provision would also require the willingness of the courts to apply this provision, which has led a 'dormant' existence to this date. There is no evidence that such a will exists. We can therefore safely state that the Dutch immunity regime, like the British one, does not provide for inviolability.

Among the three case studies, the French inviolability regime thus constitutes an exception. It should, however, be noted that inviolability by no means appears to be exceptional in a larger reference group; most states on the European continent and many others in the world (usually those without a British colonial history) grant their parliamentarians freedom from arrest or an even broader form of inviolability which protects them from criminal and civil action for the duration of the parliamentary mandate.

\subsubsection{The Case of the Netherlands: Towards Political Immunity?}

We have seen that Dutch parliamentarians are not protected by any form of immunity with regard to their acts and utterances outside parliament. However, it is sometimes argued - and recognised by the Dutch courts with reference to ECtHR case law - that elected parliamentarians must be given as wide a freedom of expression as possible. Hence, limitations of that right must not be accepted easily. The conviction of members of parliament for speech crimes is therefore unlikely, as illustrated by the case of Geert Wilders. 
Nonetheless, if, and the extent to which, Dutch politicians (and parliamentarians in particular) can really be said to enjoy greater freedom of speech than ordinary citizens cannot be determined with certainty. In particular, it is not clearly foreseeable in which cases the courts will be inclined to distinguish between politicians and other citizens in the assessment of alleged crimes of utterance. This question, and with it the system of parliamentary immunity, received an unusually high degree of public attention. Some have argued that the scope of parliamentary non-accountability must be broadened to cover all contributions to public debate, whether they are made in or outside parliament. Our analysis has shown that such a measure is legally impossible insofar as parliamentary immunity is considered an institutional privilege, which is clearly the case in the Netherlands. In the light of national constitutional principles, but also vis-à-vis the ECHR, parliamentary immunity is justified by its institutional character. Extra-parliamentary nonaccountability would lack this necessary justificatory link with the institution of parliament.

The same would be true in case of the introduction of an even wider political immunity which covers members of parliament and other citizens alike, and generally protects political speech and contributions to public debate. Such an immunity would place freedom of speech above other fundamental rights and would therefore be manifestly at odds with the ECHR and other international instruments by which the Netherlands is bound, such as the International Convention on the Elimination of all Racial Discrimination (ICERD). It would also impose on the courts the difficult task of defining 'political' speech and thus deciding whether a certain utterance is covered by immunity. Since the courts would inevitably have to take this difficult decision, it is questionable whether the introduction of political immunity would even reach its aim of withdrawing political debate in its entirety from the application of the (criminal) law. Even if political discourse in the Netherlands should come to the conclusion that greater freedom of speech - for politicians or for all - is in principle desirable, our analysis shows that both broadening parliamentary non-accountability and introducing a form of political immunity would be highly problematic from a legal point of view.

\subsection{The Immunity of the European Parliament}

The immunity system which protects the European Parliament also consists of nonaccountability and inviolability. Article 8 of Protocol no. 7 provides for absolute non-accountability, while Article 9 of that Protocol provides for a combination of the immunity regimes of the Member States and consequently a broad 'European immunity'. Which system applies in a given case depends on whether the MEP facing legal action has committed the act to which the action relates at home or in another Member State. This system is discriminatory, as not all Member States grant their parliamentarians inviolability: an MEP from a Member State without inviolability can potentially be prosecuted in his home Member State for an act which would be covered by inviolability in another. The European Parliament tries to remedy this discriminatory effect by making use of its discretionary power to 
waive or assert immunity. However, in the (as of yet) hypothetical scenario that this power is applied to grant MEPs inviolability even where it does not exist under the material rules of the Member State concerned, this would give rise to legal problems. Even though it cannot be ruled out that the European Parliament would, in such a case, attempt to 'create' inviolability by asserting it, it is highly unlikely that this would be accepted in court, either on a Member State level or before the CJEU.

\subsection{ECtHR and CJEU: A Functional Approach Towards Parliamentary Immunity}

We have shown in Chapter II that the European Court of Human Rights has adopted a functional approach towards parliamentary immunity. This means that it regards immunity as legitimate and 'necessary in a democratic society' as long as the act or utterance to which a legal action against a parliamentarian relates is materially connected to the core functions of the parliamentary mandate. The definition of these functions is relatively narrow and, above all, based on an institutional view of parliament and its members. It is assumed that the primary task of a parliamentarian is to take part in the 'corporate' activity of parliament, that is, to take part in plenary debates, to deliberate in committees and to vote on legislation. Other activities, which are equally part of the work of a member of parliament but do not immediately relate to the institution of parliament - such as campaigning for elections or participating in political debate outside parliament do not fall within this definition of functions of the parliamentary mandate.

It cannot be determined whether the ECtHR, in adopting this approach, has been fully aware of the very different consequences it has, respectively, for the legitimacy of non-accountability and inviolability. In its case law, the ECtHR usually does not treat non-accountability and inviolability as separate forms of immunity. Instead, it usually refers summarily to 'parliamentary immunity'. Upon a closer look, however, it becomes clear that the Court's functional approach has the effect that inviolability is in principle dismissed as an illegitimate violation of the right of access to court, while non-accountability is accepted. Non-accountability relates mainly to what is spoken or written in parliament, or very closely connected to actual parliamentary activity. According to the Court in Strasbourg, to protect this is necessary in a democratic society. However, the further removed an act or utterance is from the activity of parliament as an institution, the less likely it is that the limitation of the rights of third persons by the operation of immunity is acceptable. It follows that inviolability, which is by definition an extra-professional immunity, is in principle problematic and will be deemed to violate the ECHR unless there are additional reasons for its legitimacy.

The above approach is clearly visible in ECtHR case law. In $A v$. the UK, the leading case to which we already referred at the very beginning of this book, a citizen wished to sue a member of the British Parliament for defamation after he had disclosed her name and address, and made injurious comments about her in a parliamentary speech. The ECtHR was of the opinion that, however grievous for the 
applicant, freedom of speech in parliament was of paramount value in a democratic society. It therefore upheld non-accountability (parliamentary privilege ex Article 9 of the Bill of Rights 1689) as a legitimate limitation of the right of access to court. However, in a series of decisions starting with Cordova v. Italy, the Court held that non-accountability did not constitute a legitimate limitation of the rights ex Article 6 of the Convention where the insulting statements at issue had been made outside parliament and did not bear a sufficiently close connection with parliamentary activity. Pursuing its functional approach further, the Court has consistently deemed inviolability - immunity protecting parliamentarians from legal action for crimes committed in the extra-professional sphere - as incompatible with the Convention. This was the case in Tsalkitzis $v$. Greece, where the alleged criminal acts in question (blackmail and corruption) had taken place before the perpetrator's election to parliament, and in Syngelidis v. Greece, where inviolability prevented the ex-husband of a parliamentarian from bringing legal action against his former spouse in an entirely private matter of child custody. It follows from consistent ECtHR case law, concerning the legitimacy of parliamentary immunity as a limitation of the right of access to court, that narrow non-accountability - freedom of speech - is considered legitimate, whereas any further-reaching immunity will only be accepted if merited by additional reasons, for example, if it can be established that legal proceedings against parliamentarians are politically motivated.

When dealing with the immunity system of the European Parliament, the Court of Justice of the European Union (CJEU) has taken a similar approach, at least with regard to non-accountability pursuant to Article 8 of Protocol no. 7 to the Treaty on European Union, which protects members from legal action in respect of opinions expressed 'in the performance of their duties'. In its decision in Aldo Patriciello (2011), the CJEU ruled that, in order to be protected by non-accountability, an opinion expressed by a member of the EP must bear a 'clear and obvious' connection with the parliamentary functions of that member. It does not suffice, therefore, that the opinion is of a political nature. Though CJEU case law on the matter is entirely scarce - there is none with regard to inviolability - this suggests that the approach of the Court of Justice follows that of the ECtHR.

\subsection{Do National Systems Develop in a 'Functional' Direction?}

We have raised the hypothesis that national systems of parliamentary immunity in Europe are generally developing towards a model which satisfies the functional criterion of the ECtHR. In concrete terms, this means that inviolability, where it exists, is gradually reduced to a minimum or even abolished, while nonaccountability is applied restrictively with regard to extra-parliamentary utterances without a manifest connection to actual parliamentary activity.

Recent developments in two of the three systems we have examined show evidence in support of this hypothesis. In the United Kingdom, both parliamentary committees and the Supreme Court have recently given an increasingly narrow interpretation to 'proceedings in Parliament'; the concept now hardly reaches 
beyond written and oral utterances in or closely related to actual debate. Statutory legislation which will clearly define privilege and allow the use of 'proceedings' as evidence in criminal lawsuits also seems to be imminent. Beginning from the last decade of the previous century, a clear and lasting tendency to rationalise the system of British parliamentary privilege can be observed - to cut it back to what is strictly necessary to protect free deliberations in Westminster Parliament.

In France, the trend is less evident but still present: the constitutional amendment of 1995 has abolished the prohibition of criminal proceedings against parliamentarians without authorisation, the explicit aim being to limit inviolability 'to the guarantees strictly necessary for the exercise of the parliamentary mandate'. Non-accountability for utterances outside actual debates in parliament has been given a narrow interpretation in case law; it does not apply where a member of parliament is speaking in a personal capacity without a parliamentary assignment (for example in a televised interview, even though he is merely repeating what has been said or written in parliament earlier) or on a mission sponsored by the executive.

The Dutch immunity system, which does not provide for inviolability, is already consistent with the functional criterion of the ECtHR, it has even been found by some to be too narrow to protect the work of a modern parliamentarian whose task as a representative of the people includes engaging in controversial public debate. It is highly unlikely that the limited level of immunity which exists in the Netherlands will be reduced even further - certainly not due to pressure from Strasbourg. But perhaps the Netherlands is approaching functionality from the other end of the immunity scale? If political majorities and the courts were to agree that the functions which come with the parliamentary mandate are not confined to actual parliamentary debates, this could eventually lead to a redefinition of the narrow, institution-based view of the mandate which has brought about the European functional model of parliamentary immunity. It would mean to accept that the tasks of a modern parliamentarian necessarily include extra-parliamentary activities - in particular, political statements outside parliament - which deserve a degree of protection. It is possible to interpret Dutch judicial practice in this way: as the case of Geert Wilders amply illustrates, the courts are utterly reluctant to convict politicians of crimes of utterance, even where the letter of the criminal law would suggest - or possibly demand - a conviction.

Certainly, based on an examination of only the most recent developments in only three systems, we are unable to really confirm the hypothesis of a slow-moving European consensus with regard to the acceptable and necessary scope of parliamentary immunity. Nevertheless, after our analysis of three national systems, the immunity regime of the European Parliament, and the relevant case law of the ECtHR, we are certainly in a position to suggest the existence of a trend: there are no signs of a development towards more immunity than fits the functional model. 


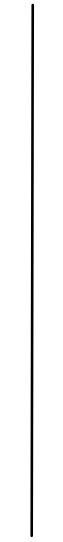

\section{BIBLIOGRAPHY}

\section{Akkermans 1987}

Akkermans, P. (ed.), De Grondwet - Een artikelsgewijs commentaar, Zwolle: Tjeenk Willink, 1987.

\section{Akkermans \& Koekkoek 1992}

Akkermans, P.W.C. \& Koekkoek, A.K. (eds.), De Grondwet. Een artikelsgewijs commentaar, $2^{\text {nd }}$ edn., Zwolle: Tjeenk Willink, 1992.

\section{Avril \& Gicquel 2010}

Avril, P. \& Gicquel, J., Droit Parlementaire, $4^{\text {th }}$ edn., Paris: Montchrestien, 2010.

\section{Barnett 2009}

Barnett, H., Constitutional $\mathcal{E}$ Administrative Law, $7^{\text {th }}$ edn., Abingdon: RoutledgeCavendish, 2009.

\section{Berkhout 2009}

Berkhout, C., 'Geert Wilders: Een Gemiste Kans?', Nederlands Juristenblad, 2009, Vol. 32(84), p. 2057-2060.

\section{Berman \& Picard 2008}

Bermann, G. \& Picard, E., Introduction to French Law, Alphen aan den Rijn: Wolters Kluwer, 2008.

\section{Bigaut 1989}

Bigaut, Ch., Vivien c/ Eglise de Scientologie, CA Paris 11 March 1987 (case note), Les petites affiches, No. 150, 21 October 1989, p. 12.

\section{Bigaut 1996}

Bigaut, Ch., La responsabilité pénale des hommes politiques, Paris: L.G.D.J., 1996.

\section{Blackstone 1832}

Blackstone, W., Commentary on the Laws of England, 18 ${ }^{\text {th }}$ edn., Vol. 1, New York: Collins \& Co., 1832. 
Bibliography

\section{Bonnotte 2002}

Bonnotte, C., Recherche sur la notion d'immunité en droit constitutionnel français, [s.l.]: the author, 2002 (doctoral thesis, Université de Limoges, unpublished).

Bovend'Eert et al. 2009

Bovend'Eert, P. et al., Grondwet - Tekst E Commentaar, 3 ${ }^{\text {rd }}$ edn., Deventer: Kluwer, 2009.

Bovend'Eert \& Kummeling 2010

Bovend'Eert, P. \& Kummeling, H., Het Nederlandse Parlement, $11^{\text {th }}$ edn., Kluwer: Deventer, 2010.

\section{Brette 1894-1915}

Brette, A. (ed.), Recueil de documents relatifs à la convocation des États généraux de 1789,

Paris: Imprimerie Nationale, 1894-1915. Available online at: <http://archive.org/stream/recueildedocume01fragoog\#page/n8/mode/2up>.

\section{Brunet 2004}

Brunet, P., Vouloir pour la Nation, Paris: L.G.D.J., 2004.

\section{Buchez \& Roux 1834}

Buchez, Ph.J.B. \& Roux, P.Ch., Histoire Parlementaire de la Révolution Française, Vol. 2, Paris: Imprimerie Félix Locquin, 1834. Available online at: <http://gallica.bnf.fr/ark:/12148/bpt6k288684/f3.image>.

\section{Buijs 1883-1888}

Buijs, J.Th., De Grondwet - Toelichting en Kritiek, Vol. 1-3, Arnhem: P. Gouda Quint, 1883-1888

\section{Calvo 1995}

Calvo, J., 'L'immunité parlementaire en droit français', Les petites affiches, No. 114, 22 September 1995, p. 7-11.

\section{Carré de Malberg 1920-1922}

Carré de Malberg, R., Contribution à la théorie générale de l'état, Vol. 1-2, Paris: Sirey, 1920-1922.

\section{Chafetz 2007}

Chafetz, J., Democracy's Privileged Few, New Haven/London: Yale University Press, 2007.

\section{Chantebout 2007}

Chantebout, B., Droit Constitutionnel, 24 ${ }^{\text {th }}$ edn., Paris: Sirey, 2007. 


\section{Coke 1797}

Coke, E., Fourth Part of the Institutes of the Lawes of England: Concerning the Jurisdiction of Courts, (reprint) London: E. \& R. Brooks, 1797. Available on Google Books at: $<$ http:/ / books.google.nl/books?id=ulE0AAAAIAAJ\&hl=de\&pg=PP9\# $=$ onepage\& $\mathrm{q} \& \mathrm{f}=$ false $>$.

Committee on Issue of Privilege (report) 2010

Committee on Issue of Privilege, Police Searches on the Parliamentary Estate, first report, 22 March 2010, HC 62.

Committee of Privileges (report) 1976-1977

Third Report of the Committee of Privileges 1976-1977, HC 417.

Committee on standards in public life (report) 2009

Committee on standards in public life, 12th report, MPs' Expenses and Allowances, 2009.

Committee on the Official Secrets Act (report) 1938-1939

Report from the Select Committee on the Official Secrets Act (1938-39, HC 101).

De Gou 1995

De Gou, L. (ed.), De Staatsregeling van 1801. Bronnen voor de totstandkoming, Den Haag: Instituut voor Nederlandse Geschiedenis, 1995.

\section{De grondwet 1994}

De Grondwet 1987: met verwijzingen per artikel naar overeenkomstige bepalingen van eerdere grondwetten, 12 ${ }^{\text {th }}$ edn., Zwolle: Tjeenk Willink, 1994.

De Soto et al. 1946

De Soto, J. et al., Refaites une constitution, Paris: La Jeune Parque, 1946.

De Volkskrant, 11 January 2011

'Halsema: Meer parlementaire onschendbaarheid', De Volkskrant, 11 January 2011.

De Volkskrant, 8 August 2007

Wilders, G., 'Genoeg is genoeg: verbied de Koran', De Volkskrant, 8 August 2007.

De Vos van Steenwijk 1927

De Vos van Steenwijk, R.H. baron, 'Parlementaire Immuniteit', in: Krabbe, H. et al., Staatsrechtelijke Opstellen (liber amicorum H. Krabbe), Vol. 2, the Hague: Martinus Nijhoff, 1927, p. 103-125.

Defamation Bill (research paper) 2012

Horne, A., Defamation Bill, House of Commons Library, research paper 12/30, 28 May 2012. 
Bibliography

\section{Dicey 1860}

Dicey, A.V., The Privy Council, Oxford: Shrimpton, 1860.

\section{Dommering 2011}

Dommering, E., HR 17 June 2011 (case note), published on the website of the Institute for Information Law (Instituut voor informatierecht, IViR) at the University of Amsterdam. Available at: <www.ivir.nl/publicaties/dommering/Annotatie_NJ_2011_450.pdf>.

\section{Drexhage 2011}

Drexhage, B., 'Drie misverstanden over de parlementaire immuniteit', in: Breunesse, H.-M. et. al., Het schip van staat - liber amicorum René Mazel, Nijmegen: Wolf Legal Publishers, 2011, p. 65-82.

\section{Duez 2004}

Duez, P., Traité de droit constitutionnel, (Paris: Dalloz Paris, 1933) re-ed., Paris: Panthéon-Assas, 2004.

\section{Duverger 1991}

Duverger, M., Les constitutions de la France, $12^{\text {th }}$ edn., Paris: Presses Universitaires de France, 1991.

\section{Elton 1982}

Elton, G.R., The Tudor Constitution, Cambridge: Cambridge University Press, 1982.

\section{Elzinga 1986}

Elzinga, D.J., 'Parlementaire onschendbaarheid voor volksvertegenwoordigers verouderd instituut of onmisbare bescherming?', in: Heringa, A.W. et al. (eds.), Staatkundig Jaarboek 1986, Nijmegen: Ars Aequi Libri, 1986, p. 211-234.

\section{Elzinga 1990}

Elzinga, D.J., De Staat van het Recht, Zwolle: Tjeenk Willink, 1990.

\section{Elzinga \& De Lange 2006}

Elzinga, D.J. \& De Lange, R. (eds.), Van der Pot - Handboek van het Nederlandse Staatsrecht, 15 $5^{\text {th }}$ edn., Deventer: Kluwer, 2006.

\section{Esmein 1927}

Esmein, A., Eléments de droit constitutionnel français et comparé, $8^{\text {th }}$ edn., Vol. 1, Paris: Sirey, 1927.

\section{Fombad 2008}

Fombad, Ch.M., 'Constitutional Reforms in France and their Implications for Constitutionalism in Francophone Africa', Open Society Institute Africa Governance Monitoring \& Advocacy Project (AfriMAP), Working Paper, 2008. 


\section{Franssen \& Van Schagen 1990}

Franssen, H. \& Van Schagen, J., Over de order miijheer de voorzitter - werkwijze van de Tweede Kamer, the Hague: SDU, 1990.

\section{Fraisseix 1999}

Fraisseix, P., 'Les parlementaires et la justice: la procédure de suspension de la détention, des mesures privatives ou restrictives de liberté, et de la poursuite', Revue française de droit constitutionnel, 1999, Vol. 39, p. 497-540.

\section{Glenn 2007}

Glenn, H.P., 'Comparing', in: Örücü, E. \& Nelken, D. (eds.), Comparative Law, Oxford/Portland (Oregon): Hart Publishing, 2007, p. 91-108.

\section{Guérin-Bargues 2011}

Guérin-Bargues, C., Immunités parlementaires et régime représentatif. L'apport du droit constitutionnel comparé (France, Angleterre, États-Unis), Paris: L.G.D.J., 2011.

\section{Hamon \& Troper 2009}

Hamon, F. \& Troper, M., Droit constitutionnel, 31 ${ }^{\text {st }}$ edn., Paris: L.G.D.J., 2009.

\section{Hardt \& Eliantonio 2011}

Hardt, S. \& Eliantonio, M., 'Thou Shalt be Saved (from Trial)? The Ruling of the Italian Constitutional Court on Berlusconi's Immunity Law in a Comparative Perspective', European Constitiutional Law Review, 2011, Vol. 7(1), p. 17-39.

\section{Harms 1968}

Harms, Th., Die Rechtsstellung des Abgeordneten in der Beratenden Versammlung des Europarates und im Europaïschen Parlament, Hamburg: Hansischer Gildenverlag, 1968.

\section{Hatsell 1818}

Hatsell, J., Precedents of Proceedings in the House of Commons; with Observations, $2^{\text {nd }}$ edn., Vol. 2, London: Clarke \& Sons, 1818.

\section{Heringa et al. 1986}

Heringa, A.W. et al. (eds.), Staatkundig Jaarboek 1986, Nijmegen: Ars Aequi Libri, 1986.

\section{Hood Phillips et al. 2001}

Hood Phillips, O., Jackson, P. \& Leopold, P. (eds.), Constitutional and Administrative Law, 8 ${ }^{\text {th }}$ edn., London: Sweet \& Maxwell, 2001.

Interparliamentary Union (background paper) 2006

Inter-Parliamentary Union, Parliamentary Immunity (draft background paper), Geneva, September 2006. 


\section{Isar 1994}

Isar, H., 'Immunité parlementaire ou impunité du parlementaire?', Revue Française de Droit Constitutionnel, 1994, Vol. 20, p. 675-711.

\section{Jansen 2006}

Jansen, N., 'Comparative Law and Comparative Knowledge', in: Reimann, M. \& Zimmermann, R. (eds.), The Oxford Handbook of Comparative Law, Oxford: Oxford University Press, 2006, p. 306-336.

Joint Committee on Parliamentary Privilege (report) 1999

Joint Committee on Parliamentary Privilege, First Report, 1999, HL 43-I, HC 214-I.

\section{Kelsen 1945}

Kelsen, H., General Theory of Law and State, Cambridge (Ma.): Harvard University Press, 1945.

\section{Kiiver \& Kornet 2010}

Kiiver, P. \& Kornet, N., The Maastricht Collection, Groningen: Europa Law Publishing, 2010.

\section{Kloth 2010}

Kloth, M., Immunities and the Rights of Access to Court under Article 6 of the European Convention on Human Rights, Leiden/Boston: Martinus Nijhoff, 2010.

\section{Kluit 1803}

Kluit, A., Historie der Hollandsche Staatsregering, part 3, Amsterdam: Wouter Brave, 1803.

Kortmann 1993

Kortmann, C., 'Vrijheid van meningsuiting voor de regering?', Nederlands Juristenblad, 1993, 10(68), p. 333-334.

\section{Kranenburg 1938}

Kranenburg, R., Het Nederlandse Staatsrecht, $5^{\text {th }}$ edn., Haarlem: Tjeenk Willink, 1938.

\section{Kranenburg 1947}

Kranenburg, R., Het Nederlandse Staatsrecht, $6^{\text {th }}$ edn., Haarlem: Tjeenk Willink, 1947.

\section{Kranenburg 1958}

Kranenburg, R., Het Nederlandse Staatsrecht, 8th edn., Haarlem: Tjeenk Willink, 1958.

\section{Leopold 1990}

Leopold, P.M., 'The Parliamentary Papers Act 1840 and its application today', Public Law, 1990, Vol. 3 (SUM), p. 183-206. 


\section{Leopold 1998}

Leopold, P., 'The Application of the Civil and Criminal Law to Members of Parliament and Parliamentary Proceedings', in: Oliver, D. \& Drewry, G. (eds.), The Law and Parliament, London: Butterworths, 1998, p. 71-87.

\section{Lock 1998}

Lock, G., 'Statute Law and Case Law Applicable to Parliament', in: Oliver, D. \& Drewry, G. (eds.), The Law and Parliament, London: Butterworths, 1998, p. 48-70.

\section{Loveland 2000}

Loveland, I., Political Libels, Oxford/Portland/Oregon: Hart Publishing, 2000.

\section{Loveland \& Sharland 1997}

Loveland, I. \& Sharland, A., 'The Defamation Act 1996 and Political Libels', Public Law, 1997, Vol. 2, (SPR), p. 113-124.

\section{Luchaire \& Conac 1980}

Luchaire, F. \& Conac, G. (eds.), La constitution de la République française, Paris: Economica, 1980.

\section{Luchaire et al. 2009}

Luchaire, F. et al. (eds.), La constitution de la République française, 3rd edn., Paris: Economica, 2009.

\section{Maingot 2010}

Maingot, J., Politicians above the Law, Ottawa: Baico Publishing, 2010.

\section{Major 1980}

Major, J.R., Representative Government in Early Modern France, New Haven/London: Yale University Press, 1980.

\section{Marchand 1950}

Marchand, P., Les Immunités Parlementaires et la IVème République, [s.1.]: the author, 1950 (doctoral thesis: Université de Paris, unpublished).

\section{Martin \& Cabanis 2000}

Martin, M.L. \& Cabanis, A., Histoire constitutionnelle et politique de la France de la Révolution à nos jours, Paris: L.G.D.J., 2000.

\section{McIlwain 1910}

McIlwain, Ch.H., The High Court of Parliament and its Supremacy, New Haven: Yale University Press, 1910.

\section{McKay et al. (Erskine May) 2004}

McKay, W. et al. (eds.), Erskine May's Treatise on The Law, Privileges, Proceedings and Usage of Parliament, 23rd edn., London: LexisNexis, 2004. 
Bibliography

Mehta 2012

Mehta, R.S., 'Sir Thomas' Blushes: Protecting Parliamentary Immunity in Modern

Parliamentary Democracies', Human Rights Law Review, 2012, Vol. 3(17), p. 309-318.

\section{Michelet 1889}

Michelet, J., Histoire de la Révolution Française, Vol. 1, Paris: Imprimerie Nationale, 1889.

\section{Munro 1999}

Munro, C., Studies in Constitutional Law, $2^{\text {nd }}$ edn., London: Butterworths, 1999.

\section{Nehmelman 2010a}

Nehmelman, R. (ed.), Parlementaire immuniteit vanuit een Europese context bezien, Nijmegen: Wolf Legal Publishers, 2010.

\section{Nehmelman 2010b}

Nehmelman, R., 'De verboden politieke meningsuiting als ambtsmisdrijf', in Nehmelman, R. (ed.), Parlementaire immuniteit vanuit een Europese context bezien, Nijmegen: Wolf Legal Publishers, 2010, p. 7-23.

\section{Nehmelman 2011}

Nehmelman, R., 'Spreken is zilver, maar wie bepaalt wanneer zwijgen goud is?' , Ars Aequi, 2011, Vol. 5(60), p. 355-360.

\section{Nieuwenhuis 2010}

Nieuwenhuis, A., 'Tussen grondrechtelijke vrijheid en parlementaire onschendbaarheid: de vrijheid van meningsuiting van de parlementariër', Tijdschrift van Constitutioneel Recht, 2010, Vol. 1(1), p. 4-23.

\section{Nieuwenhuis \& Janssens 2011}

Nieuwenhuis, A. \& Janssens, A., Uitingsdelicten, Deventer: Kluwer, 2011.

\section{Nolan Report 1995}

Public Life, First Report of the Committee of Standards in Public Life [Nolan Report], London: HMSO, 1995.

Offermann (study DG Internal Policies) 2007

Offermann, K., Parliamentary Immunity in the European Parliament, Internal Study, DG Internal Policies, European Parliament, 2005 (updated 2007), doc. no. PE 360.487/REV2.

Oliver 1993

Oliver, D., 'Pepper v. Hart: A Suitable Case for Reference to Hansard?', Public Law, 1993, Vol. 2, (SPR), p. 5-13. 
Örücü \& Nelken 2007

Örücü, E. \& Nelken, D. (eds.), Comparative Law, Oxford/Portland (Oregon): Hart Publishing, 2007.

\section{Özbudun 2005}

Özbudun, E., 'Constitutional Debates on Parliamentary Inviolability in Turkey', European Constitutional Law Review, 2005, Vol. 2(1), p. 272-280.

PACE Committee on Legal Affairs and Human Rights 2010

PACE Committee on Legal Affairs and Human Rights (AS/Jur), Strengthening Subsidiarity: Integrating the Strasbourg Court's Case law into National Law and Judicial Practice, Contribution to the Conference on the Principle of Subsidiarity, Skopje, 1-2 October 2010. Available at: <http://assembly.coe.int/CommitteeDocs/2010/20101125_skopje.pdf>.

\section{Pactet \& Mélin-Soucramanien 2007}

Pactet, P. \& Mélin-Soucramanien, F., Droit constitutionnel, 26 $6^{\text {th }}$ edn., Paris: Dalloz, 2007.

Parliamentary privilege: current issues (briefing paper) 2012

Gay, O., Parliamentary Privilege: Current Issues, House of Commons Library, Parliament and Constitution Centre, 18 July 2012, document no. SN/PC/06390.

Peters 2010

Peters, J., 'Immuniteit ook buiten het parlementair debat', Tijdschrift voor Constitutioneel Recht, 2010, Vol. 1(3), p. 327-330.

Procedure Committee (report) 2010-2012

Procedure committee, $6^{\text {th }}$ report 2010-2012, Lay Membership of the Committee on Standards and Privileges, HC 1606.

\section{Riberi 2007}

Riberi, P., 'Delimiting Constitutional Limits as a Democratic Constitutionalism Sees Fit', paper presented at the $7^{\text {th }}$ World Congress of Constitutional Law: Rethinking the boundaries of constitutional Law, Athens, June 2007. Available at: <www.enelsyn.gr/papers/w9/Paper\%20by\%20Professor\%20Pablo\%20Riberi.pdf>.

\section{Sottiaux 2010}

Sottiaux, S., 'Parlementaire immuniteit en de uitingsvrijheid van parlementsleden in de Belgische Grondwet', in: Nehmelman, R. (ed.), Parlementaire immuniteit vanuit een Europese context bezien, Nijmegen: Wolf Legal Publishers, 2010, p. 59-67.

\section{Soulier 1966}

Soulier, G., L'inviolabilité parlementaire en droit français, Paris: L.G.D.J., 1966. 
The Telegraph Online, 8 May 2009

'Full list of MPs investigated by The Telegraph', The Telegraph online, 8 May 2009, available at: <www.telegraph.co.uk/news/newstopics/mps-expenses/5297606/MPs-expenses-Full-list-of-MPs-investigated-by-the-Telegraph.html>, retrieved on 26 October 2012.

The Daily Mail Online, 9 May 2009

Chapman, J., 'Police Hunt Expenses Mole', The Daily Mail online, 9 May 2009, available at: <www.dailymail.co.uk/news/article-1179578/Police-hunt-expensesmole-businessman-hawks-details-MPs-receipts.html>, retrieved on 26 October 2012.

\section{Thorbecke 1840}

Thorbecke, J.R., Proeve van herziening der grondwet, Leiden: H.W. Hazenberg, 1840.

\section{Thorbecke 1841-1843}

Thorbecke, J.R., Aantekening op de Grondwet, Vol. 1 \& 2, Amsterdam: Johannes Müller, 1841-1843.

\section{Thumerel 2010}

Thumerel, I., 'La participation du people par l'élection dans les constitutions de 1791 à $1848^{\prime}$, Jurisdoctoria, 2010, Vol. 4, p. 17-54.

\section{Van Caenegem 1995}

Van Caenegem, R., A Historical Introduction to Western Constitutional Law, Cambridge: Cambridge University Press, 1995.

\section{Van den Berg 2011}

Van den Berg, J., 'Geen gewone burger', column on the website Parlement \& Politiek (parlement.com), 1 July 2011. Available at: <www.parlement.com/id/viqkhhrqr9vy/geen_gewone_burger>.

Van den Berg \& Vis 2013

Van den Berg, J. \& Vis, J., De eerste honderdvijftig jaar - parlementaire geschiedenis van Nederlands 1796-1946, Amsterdam: Bert Bakker, 2013.

\section{Van der Hulst 2000}

Van der Hulst, M., The Parliamentary Mandate, Geneva: Inter-Parliamentary Union, 2000.

\section{Van Emden 1857}

Van Emden, A.J., De onschendbaarheid van de leden der volksvertegenwoordiging, Amsterdam: C.G. van der Post, 1857.

\section{Van Hasselt 1987}

Van Hasselt, W.J. (ed.), Nederlandse staatsregelingen en grondwetten, 17th edn., Alphen aan den Rijn: Samson, 1987. 
Van Os 1910

Van Os, W.A.E., De onschendbaarheid der volksvertegenwoordigers, Groningen: Wolters, 1910.

Van Raalte 1971

Van Raalte, E., Het Nederlandse Parlement, the Hague: Staatsuitgeverij, 1971.

\section{Verhagen 1949}

Verhagen, D.R.C., L'influence de la Révolution française sur la première Constitution hollandaise du 23 avril 1798, Utrecht: Kemink, 1949.

\section{Vogel 2008}

Vogel, W., 'Frankreichs Verfassung 1958-2008', in: Deutsch-Französisches Institut, Frankreich Jahrbuch 2007, 50 Jahre V. Republik, Wiesbaden: VS Verlag für Sozialwissenschaften, 2008, p. 11-30.

\section{Wigley 2003}

Wigley, S., 'Parliamentary Immunity: Defending Democracy or Defending Corruption?', Journal of Political Philosophy, 2003, Vol. 2(11), p. 23-40.

\section{Wigley 2009}

Wigley, S., 'Parliamentary Immunity in Developing Countries', Human Rights Quarterly, 2009, Vol. 3(31), p. 567-591.

\section{Wijman 1995}

Wijman, M., Grenzen aan Onschendbaarheid, Utrecht: Universiteit Utrecht, 1995.

\section{Williams 1997}

Williams, K., "'Only Flattery is Safe”: Political Speech and the Defamation Act 1996', The Modern Law Review, 1997, Vol. 3(60), p. 388-393.

\section{Wittke 1970}

Wittke, C., The History of English Parliamentary Privilege, reprint (originally The Ohio State University Bulletin, 1921, Vol. 2(26)), New York: Da Capo Press, 1970. 



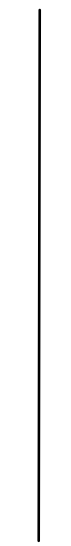

\section{POLITICAL DOCUMENTS}

Green Paper on Parliamentary Privilege, Cm8318, published on 26 April 2012.

High Level Conference on the Future of the European Court of Human Rights, Interlaken Declaration, 19 February 2010.

Information about the allowances paid to the members of the British Parliament on the parliamentary website: <www.parliament.uk/mps-lords-and-offices/membersallowances/>.

The Queen's Speech 2012, House of Commons Library standard note of 18 April 2012, $\mathrm{SN} / \mathrm{PC} / 06254$, p. 8. The Queen's Speech is available on the website of 10 Downing Street: <www.number10.gov.uk/news/queens-speech-2010-2/>. 



\section{CURRICULUM VITAE}

Sascha Hardt was born in 1984 in Wuppertal, Germany. He studied Dutch, European and International Law at Maastricht University as of 2004 and obtained his LL.M degree (European Law School) in 2008. In February 2009 he assumed a position as a junior researcher at the department of public law at Maastricht University where he has completed this thesis in 2013. He remains with the department of public law as an assistant professor of comparative constitutional law. Sascha Hardt is a fellow of the Montesquieu Institute Maastricht. 



\section{IUS COMMUNE EUROPAEUM}

A peer-reviewed book series in which the common foundations of the legal systems of the Member States of the European Union are the central focus.

The Ius Commune Europaeum series includes horizontal comparative legal studies as well as studies on the effect of treaties within the national legal systems. All the classic fields of law are covered. The books are published in various European languages under the auspices of METRO, the Institute for Transnational Legal Research at the Maastricht University.

Editorial Board: Prof.Dr. J. SMits (chair), Prof.Dr. M. FAure, Prof.Dr. CHR. JOERGES, Prof.Dr. J. DU PLESSIS and Prof.Dr. E. Vos.

Recently published:

Volume 103: Linked Contracts, I. SAMOY and M.B.M. LoOS (eds.)

Volume 104: Constitutions Compared (3 ${ }^{\text {rd }}$ ed.), A.W. HERINGA and PH. KIIVER

Volume 105: Alternative Ways to Ius Commune, A.L.M. KEIRSE and M.B.M. LoOs (eds.)

Volume 106: Property Law Perspectives, B. AKKERMANS and E. RAMAEKERS (eds.)

Volume 107: Constitutional Conversations, C. VAN DE HEYNING and M. DE VISSER (eds.)

Volume 108: Enforcing Health and Safety Regulations. A Comparative Economic Approach, L. TILINDYTE

Volume 109: Administrative Law of the European Union, its Member States and the United States. A Comparative Analysis, R. SEERDEN (ed.)

Volume 110: Market Integration through 'Network Governance': The Role of European Agencies and Networks of Regulators, M. ZINZANI

Volume 111: Truth and Efficiency in Civil Litigation. Fundamental Aspects of Fact-finding and Evidence-taking in a Comparative Context, C.H. VAN RHEE and A. UZELAC (eds.)

Volume 112: Law and Security in Europe: Reconsidering the Security Constitution, M. FICHERA and J. KREMER (eds.)

Volume 113: Inside Police Custody: An Empirical Account of Suspects' Rights in Four Jurisdictions, T. SPRONKEN, E. CAPE and J. HODGSON (eds.)

Volume 114: Motive Matters! An Exploration of the Notion 'Deliberate Breach of Contract' and its Consequences for the Application of Remedies, M. VAN KOGELENBERG

Volume 115: Legal Education, A.W. HerINGA

Volume 116: Standing up for your Rights in Europe. A Comparative Study on Legal Standing (Locus Standi) before the EU and Member States' Courts, M. ELIANTONIO, CH. BACKES, C.H. VAN RHEE, T. SPRONKEN and A. BERLEE

Volume 117: European Union Property Law. From Fragments to a System, E. RAMAEKERS Volume 118: Comparing Ecological Damage. Comparative and Economic Observations, J. LIU 